Florida International University FIU Digital Commons

$11-9-2000$

\title{
World coffee markets and national coffee parastatals since 1989: a comparative study of Colombia and Cote D'ivoire
}

Laura Elizabeth Boudon

Florida International University

DOI: $10.25148 /$ etd.FI14051807

Follow this and additional works at: https://digitalcommons.fiu.edu/etd

Part of the International and Area Studies Commons, and the International Relations Commons

\section{Recommended Citation}

Boudon, Laura Elizabeth, "World coffee markets and national coffee parastatals since 1989: a comparative study of Colombia and Cote D'ivoire" (2000). FIU Electronic Theses and Dissertations. 1716.

https://digitalcommons.fiu.edu/etd/1716 
FLORIDA INTERNATIONAL UNIVERSITY

Miami, Florida

WORLD COFFEE MARKETS AND NATIONAL COFFEE PARASTATALS

SINCE 1989: A COMPARATIVE STUDY OF COLOMBIA AND COTE D'IVOIRE

A dissertation submitted in partial fulfillment of the

requirements for the degree of

DOCTOR OF PHILOSOPHY

in

INTERNATIONAL RELATIONS

by

Laura Elizabeth Boudon 
To: $\quad$ Dean Arthur W. Herriott

College of Arts and Sciences

This dissertation, written by Laura Elizabeth Boudon, and entitled World Coffee Markets and National Coffee Parastatals Since 1989: A Comparative Study of Colombia and Côte D'Ivoire, having been approved in respect to style and intellectual content, is referred to you for judgment.

We have read this dissertation and recommend that it be approved.

John Clark

Roderick Neumann

Nicholas Onuf, Major Professor

Date of Defense: November 9, 2000

The dissertation of Laura Elizabeth Boudon is approved.

Dean Arthur W. Herriott College of Arts and Sciences

Interim Dean Samuel S. Shapiro

Division of Graduate Studies

Florida International University, 2000 
(C) Copyright 2000 by Laura Elizabeth Boudon

All rights reserved. 


\section{DEDICATION}

I dedicate this dissertation to my amazing husband, H. Lawrence Boudon, and to my fantastic parents, Jacques and Bärbel Besseyre. Without the daily support, interest, patience, and love of these three wonderful individuals, the completion of this work would not have been possible. 


\section{ACKNOWLEDGMENTS}

I wish to thank numerous individuals on different continents for their assistance throughout this research and writing process. I would first like to acknowledge the four members of my dissertation committee for their support and insight at various stages. I appreciated Dr. Nicholas Onuf's insightful advising and mentoring throughout my doctoral program, as well as his willingness to lead my dissertation committee. I am grateful to Dr. John Clark for his interest in my application to the doctoral program and his continuous support of my academic endeavors. I thank Dr. Rod Neumann for always pushing me a bit further in my arguments. I am endebted to Dr. Robin King of Georgetown University for asking me about my writing on a daily basis and encouraging me to complete the dissertation.

In Colombia, I thank the Department of Political Science at the Universidad de los Andes for taking me on as a Visiting Researcher. I wish to thank Camila Botero for introducing me to the Colombian coffee region and to key informants. I am very grateful to Christopher London for his crucial assistance in obtaining interviews with FEDECAFE managers and employees during my stay in Manizales in April 1997. I would also like to recognize all the employees of FEDECAFE at various levels who accepted to speak with me about my topic.

In Côte d'Ivoire, I thank from the bottom of my heart Henriette Gomis-Billon and her family for generously opening up their house to us during our stay in Abidjan. Their insights and contacts were absolutely crucial. I also would like to extend my gratitude to Mademoiselle Léa Achépi for her assistance and welcome during our brief stay in Daloa. I 
appreciated the time taken by leaders and employees of the Caisse and ANADER to speak with me.

I appreciate the generous assistance of Birgitte and Bernard Hugouneng in enabling Larry and me to travel to Côte D'Ivoire for the Ivoirian portion of the research. Without their help, this dissertation would not be as rich in detail.

Back in the United States, I also want to acknowledge Dr. John Talbot of Colby College for his continuing interest in my topic and his comments at various stages. I have also appreciated the input of Dr. Sutti Ortiz of Boston University during the final writing stage.

Finally, I wish to thank my numerous relatives and friends in the United States and in France for listening to me talk about this dissertation for several years and accepting that at some points, it had to come first. 


\section{ABSTRACT OF THE DISSERTATION}

\section{WORLD COFFEE MARKETS AND NATIONAL COFFEE PARASTATALS \\ SINCE 1989: A COMPARATIVE STUDY OF COLOMBIA AND COTE D'IVOIRE \\ by}

Laura Elizabeth Boudon

Florida International University, 2000

Miami, Florida

Professor Nicholas Onuf, Major Professor

The International Coffee Agreements (ICA) involved the majority of nations producing and consuming coffee and provided relative economic stability to the coffee sectors of the exporting Third World countries. This study focuses on the serious impact of the 1989 collapse of the ICA on the domestic coffee sectors of Colombia and Côte d'Ivoire. In particular, the dissertation examines the role of the Colombian and Ivoirian coffee parastatals, the Federacion Nacional de Cafeteros de Colombia and the Caisse de Stabilisation et Soutien des Prix des Produits Agricoles, during the crisis and their transformation by it.

The theoretical framework employed in this study is borrowed from the literature on state-society relations. The methodology includes: in-depth analysis of the historical roles of the parastatal agencies in coffee production, state-society relations and economic development in Colombia and Côte d'Ivoire; interviews with parastatal administrators, producers and other knowledgeable informants in both countries; and a comprehensive 
review of newspaper articles and official statements of coffee policy published in Colombia and Côte d'Ivoire prior to, during, and after the crisis.

The Colombian and Ivoirian coffee sectors and their producers faced serious economic and social problems following the drop in coffee prices. The coffee parastatals in Colombia and Côte d'Ivoire first lost some of their responsibilities following the world coffee crisis. The Caisse was in the end eliminated while FEDECAFE struggled to remain in existence. Along the way, both entities faced protests from disgruntled coffee producers, who organized politically for the first time in their nations' histories. I argue that the outcome for the parastatals depended in part on the conditions of their formation, particularly the level of societal involvement in their creation. I also posit that the country's dependence on foreign aid played a key role in the fate of the parastatals.

This dissertation concludes that developments in the Colombian and Ivoirian coffee sectors have significantly contributed to the creation of the difficult political and economic conditions of both countries today. 
I INTRODUCTION.

II INTERNATIONAL POLITICAL ECONOMY OF COFFEE.................... 16

World Coffee Markets Prior to 1962 ......................................................... 17

The International Coffee Agreements (1962-1989)................................... 24

World Coffee Markets and New Ideologies Since 1989............................ 41

Conclusions........................................................................................... 48

III THEORETICAL CONSIDERATIONS................................................ 50

State-Society Relations and Parastatals in the Developing World............... 54

Adding the International Variable ............................................................ 71

Parastatals And Change................................................................... 77

FEDECAFE as a Parastatal........................................................... $\quad 82$

African Marketing Boards................................................................ 85

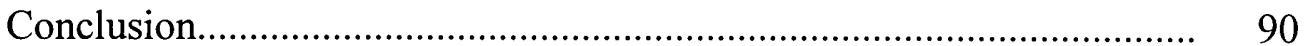

IV THE COLOMBIAN COFFEE SECTOR AND THE FEDERACION NACIONAL DE CAFETEROS DE COLOMBIA IN HISTORICAL PERSPECTIVE... 92

Origins and First Consequences of Coffee Production in Colombia............ 93

Creation of the Federación Nacional de Cafeteros de Colombia................. 103

The Colombian Coffee Sector from 1930 to 1958.................................. 110

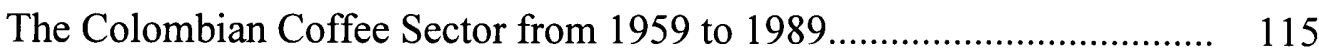

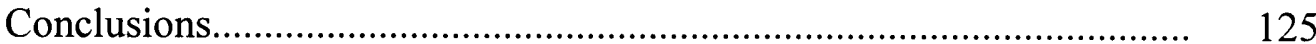

$\mathrm{V}$ THE COLOMBIAN COFFEE SECTOR AND THE FEDERACION NACIONAL DE CAFETEROS DE COLOMBIA SINCE 1989................................. 127

Colombia and the Quest for a New International Coffee Agreement........... 127

Does This Impact the Colombian Coffee Sector?.................................... 129

The Colombian Coffee Sector Feels Serious Impact............................... 137

Moving Beyond the Immediate Economic Crisis (1994-1997).................. 148

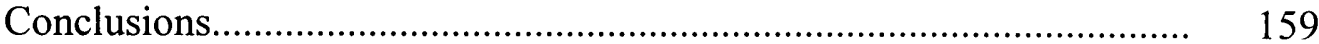

VI THE IVOIRIAN COFFEE SECTOR AND ITS PARASTATALS IN HISTORICAL PERSPECTIVE........................................................... 162

Colonial Origins of Coffee and Commodity Production.............................. 164

Creation of the Ivoirian Coffee Parastatals.............................................. 173

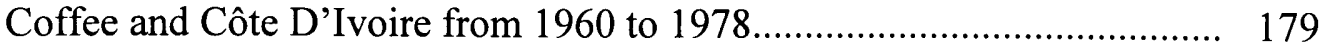

Coffee and Côte D'Ivoire from 1978 to the end of ICA............................ 188

Conclusions................................................................................... 200 
VII THE IVOIRIAN COFFEE SECTOR AND ITS PARASTATALS

SINCE 1989.............................................................................. 202

Côte d'Ivoire and the Quest for a new International Coffee Agreement...... 203

The Ivoirian Coffee Sector Falls Apart................................................... 207

Ivoirian State and Farmers Seek Real Solutions....................................... 219

Moving Beyond the Agricultural Crisis and Dealing with New Variables....230

Conclusions...................................................................................... 241

VIII COMPARATIVE ANALYSIS: COLOMBIA, COTE D'IVOIRE, AND COFFEE-PRODUCING COUNTRIES.............................................. 244

Arabica Versus Robusta.................................................................... 245

Bringing in Other Coffee-Producing Countries..................................... 259

Grinding It All Together..................................................................... 268

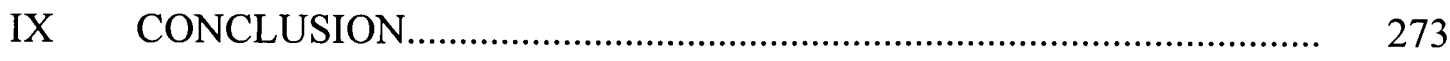

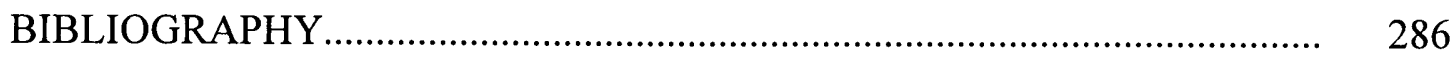

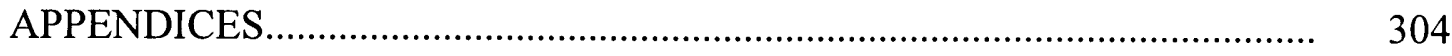

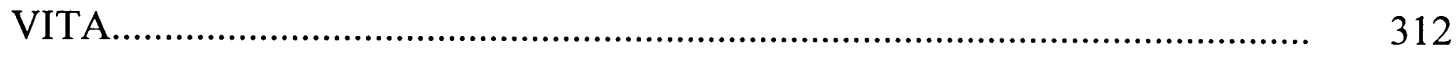




\section{INTRODUCTION}

Coffee is the key export crop for many Southern countries; it is the most important primary commodity after petroleum. Overall, coffee represents global earnings of at least $\$ 9.3$ billion per year. ${ }^{1}$ Although production takes place mostly in remote rural areas of Latin America, Africa and Asia, the industry is very affected by international events, in particular fluctuations in world markets, where the beans are traded.

Since the latter half of the 19 th century, coffee has been and continues to be a key component in the economic, political and social evolution of numerous developing countries. In the late 1950 s, the industrialized nations, and the United States in particular, began to realize the significant role of coffee in the economic development of numerous Latin American and African countries. With this in mind and a good push from the United States, countries consuming and producing coffee brokered the first of four International Coffee Agreements (ICA) in 1962. These agreements were to raise and stabilize the world market prices of the commodity for the benefit of the producing countries and their coffee growers, primarily through the use of quotas. In 1989, upon the expiration of the fourth coffee agreement, however, no consensus could be reached on a fifth treaty. In an entirely unregulated trading environment, coffee-producing states and their farmers faced rapidly decreasing prices and incomes as well as a new set of international rules governing the sale and purchase of coffee.

${ }^{1}$ Jock Finlayson and Mark Zacher, Managing International Markets: Developing Countries and the Commodity Trade Regime (New York, NY: Columbia University Press, 1988), p. 146. 
For countries where coffee was a historically important primary commodity, the international political economy of coffee significantly affected their institutional development and resulted in the creation of coffee parastatal agencies sharing a strong functional resemblance regardless of their specific institutional form. The disintegration of the coffee agreement affected these parastatals in much the same way, with demonstrably significant effects on producing states, as states, and their farmers. These generalizations are borne out in this dissertation by the case studies and comparative analysis of Colombia and Côte d'Ivoire.

Following a historical overview of the international political economy of coffee and coffee production in Colombia and Côte d'Ivoire, this study will discuss how the collapse of the International Coffee Agreement has affected the following in the two case studies: (1) the national political economy and the coffee producers in general; (2) the changing position of the coffee parastatal vis-a-vis the state and producers, specifically with regard to the financial and educational arenas; (3) the state's resulting economic and social policies towards the coffee sector and (4) the changing role of these coffee parastatal entities in national economic development. The central questions of this study are: (1) What were the contributions of the coffee parastatals to state-society relations prior to 1989? (2) How did the parastatal and its role in the coffee sector change after 1989? This analysis will also explore the historical, circumstantial and organizational differences that dictated in large part the contrasting outcomes in the two countries in question. 
The collapse of the ICA caused the Colombian and Ivoirian coffee parastatal agencies to change their primary missions as well as their relations and positions vis-a-vis the state and coffee producers. This dissertation will analyze these changes as they relate to the Federación Nacional de Cafeteros de Colombia (The National Federation of Colombian Coffee Producers, FEDERACAFE or FEDECAFE) in Colombia and $\mathrm{La}$ Caisse de Stabilisation et Soutien des Prix de Produits Agricoles (Fund for the Stabilization and Maintenance of Agricultural Product Prices, Caisse or CSSPPA) and the Société d'Assistance Technique Pour la Modernisation Agricole (Agency of Technical Assistance for Agricultural Modernization, SATMACI) in Côte d'Ivoire since 1989. Although the structural adjustment policies imposed by the International Monetary Fund and the World Bank affected and continue to impact the situations in the countries under discussion (particularly in Côte d'Ivoire), I will argue that there is, in fact, a direct relationship between the collapse of the International Coffee Agreement and the neoliberal economic policies of the international financial institutions. Specifically, the emphasis on free trade inherent within neoliberalism implies the gradual elimination of international commodity agreements. In Colombia, structural adjustment policies were implemented several years following the collapse of the coffee agreements, while in Côte d'Ivoire the economic reforms in place in 1989 had to be discontinued. The role of the IMF and the World Bank is key to understanding post-ICA developments in Côte d'Ivoire.

The basic international economics of coffee are worth reviewing briefly. The demand for coffee beans and products is generally inelastic; it is not particularly sensitive to price changes because coffee drinking is quite habit-forming. Only extremely high 
prices will change consumption patterns. Changes in coffee bean prices are therefore largely due to variations in supply, ${ }^{2}$ which are due to climactic and specific production conditions, such as frosts, droughts, and strikes. The consumer price of roasted coffee beans or instant coffee is not particularly affected by the ups and downs of the world coffee markets as it is mostly determined by the roasting and processing of the coffee by the large multinational corporations. As a result, the coffee consumer can remain largely unaware of the fluctuations of the world price of the various types of unprocessed coffee beans.

\section{Practical and Theoretical Considerations}

Scholars have studied coffee production using different levels of analyses and academic disciplines. Economists have studied the functioning of the international coffee markets and have tried to predict their fluctuations; they also study the significance of coffee in the macroeconomics of the producing and consuming countries. Political scientists have studied the role of coffee, as an export crop, in nation-building, its influence on governing coalitions, the process of negotiations for the International Coffee Agreements, the causes for its disintegration. Anthropologists study the role of coffee in local communities and how these change over time.

This dissertation began as a broad attempt to bring together the local and the global in the coffee industry, to study specifically how events at the international level of analysis (the International Coffee Agreement and its collapse; the international markets)

2 Finlayson and Zacher, p. 150. 
and events at the local level (the plight of the producers, droughts, etc.) interact with, and influence, one another. As I began my research, it became clear to me that I could not adequately answer those very broad questions within the parameters of this one study. Therefore, I had to narrow my focus to a subject that I could dissect in the context of a dissertation and one that I was theoretically equipped to handle. With this in mind, I refocused the dissertation on what was and is a key intervening variable in the intersection of the global and the local: the state and its relevant agencies in the coffee sector. The emphasis of this dissertation will thus be on the parastatal entities put in place to deal with the coffee sector in the countries under study.

Parastatals can be described in both institutional and functional terms. Much of the scholarship highlights the institutional aspect of these entities, namely their link to the state and the degree of public ownership. ${ }^{3}$ In this regard, the two agencies in this study are quite different. The Caisse is clearly a state agency whereas FEDECAFE is linked to the state in financial and structural ways but is not technically part of the state. The focus throughout this dissertation, however, will be on the functional dimensions of these coffee parastatals. The Caisse and FEDECAFE carried out many of the same tasks in their respective coffee sectors. They both oversaw the marketing and quality control of the

${ }^{3}$ For example: Leroy P. Jones (ed.), Public Enterprise in Less-Developed Countries (New York, NY: Cambridge University Press, 1982); Praxy Fernandes and Pavle Sicherl (eds.), Seeking the Personality of Public Enterprise (Ljubljana, Yugoslavia: International Center for Public Enterprises in Developing Countries, 1981); and Yair Aharoni, The Evolution and Management of State Owned Enterprises (Cambrige, MA: Ballinger Publishing Company, 1986). 
coffee crops, set producer prices and extracted revenue from coffee producers, and also served as a link between the state and the producers.

The theoretical section of the dissertation will review the few perspectives available in the literature on parastatal organizations. It will also include a discussion of associations versus parastatal organizations in the Colombian case and a presentation of the literature on African agricultural marketing boards for Côte d'Ivoire.

Many of the substantive issues raised by this study are thus related to the statesociety literature, even if little has been written in this field on the role of parastatal organizations per se. Parastatals are at the very intersection of state and society and it is because of their peculiar position that I place this discussion in the greater context of state-society relations.

For the purposes of this project, the state will be defined as a bureaucracy which "coexists and interacts [in society] with other formal and informal organizations from families to economic enterprises or religious organizations. It is however, distinguished from the myriad of other organizations in seeking predominance over them and in aiming to institute binding rules regarding the other organizations' activities." ${ }^{\prime 4}$ The definition allows us to view the state both as a bureaucracy and as a political actor. The state cannot be viewed as an amorphous entity; it also needs to be viewed as a collection of individuals with specific agendas and goals. This distinction in the roles of the state will enable us to

${ }^{4}$ Victor Azarya, "Reordering State-Society Relations: Incorporation and Disengagement," in Donald Rothchild and Naomi Chazan (eds.), The Precarious Balance: State and Society in Africa (Boulder: Westview Press, 1988), p. 10 as cited by Bratton in "Beyond The State: Civil Society and Associational Life in Africa," World Politics 41, 3 (1989), p. 408. 
gain a deeper understanding of its relations with coffee producers in Colombia and Côte d'Ivoire.

Definitions of society are generally quite vague, reflecting the fact that "society" can be understood from many different perspectives. ${ }^{5}$ Marxists believe that society can best be comprehended by studying its class structure, while statists see society as a product of the state and dependent thereon. To be sure, however, one must also make a distinction between "society" and "civil society." For Migdal, organizations within civil society differ from other groups in society because they primarily address the state. ${ }^{6}$ These groups act as channels for popular concerns and, in turn, mediate conflicts between the state and society. Other groups in society address other social entities, not the state first and foremost. Hence, "society" encompasses much more than civil society, namely all types of ethnic, religious, economic, political and social groups that are not exclusively products of state formation as is suggested by Migdal. The specific segment of society this project will deal with is the coffee producers. The theoretical chapter of the dissertation will outline the various models of state and society interaction available in the literature and will suggest arguments regarding the best suited ones for the two cases under study.

${ }^{5}$ Joel S. Migdal, The State in Society: an approach to struggles of domination," in Atul Kohli, Joel S. Migdal and Vivienne Shue (eds.) State Power and Social Forces: Domination and Transformation in the Third World (New York: Cambridge University Press, 1994), pp. 18-23.

${ }^{6}$ Joel S. Migdal, "The State in Society," p. 29. 
All the discussions of state-society relations, however, must be placed within the greater context of the international political economy. The international context is indeed critical for the description and the analysis of events in the Colombian and Ivoirian coffee sectors. An overview of the key relevant issues in the international political economy literature will thus be included in the theoretical chapter of this dissertation.

Although US foreign policy is not a primary theoretical or practical concern of this study, it does have to be discussed at various junctures because of its key role in the evolving international political economy of coffee. The United States was very involved in the creation and maintenance of the International Coffee Agreement; but it also played a key role in the collapse or disintegration of the ICA in 1989 and the fact that a new agreement was never signed. Under these circumstances, US foreign policy perspectives will be mentioned where necessary and appropriate.

\section{Bringing Together The Two Case Studies: Colombia and Côte d'Ivoire}

As stated previously, the two countries studied in this dissertation are Colombia and Côte d'Ivoire. This study will be particularly enriched by the comparison between Colombia and Côte d'Ivoire for several reasons. First, Colombia and Côte d'Ivoire were both signatories of the International Coffee Agreements and have thus endured together the consequences of the changing international political economy of coffee. In a sense, using two case studies from two different continents helps "control for" trends and forces specific to either Latin America or Sub-saharan Africa. Second, their functions in their coffee sectors and national economies are similar enough to warrant the comparison. 
Third, as we will discuss in detail in the historical chapters, coffee has played a significant role in the historical formation of the state in both countries by providing the revenue for state-building. In addition, Colombian and Ivoirian national elites had concrete ties to their respective coffee production sectors.

Prior to 1989, Colombia and Côte d'Ivoire were also respectively the second and third largest producers of coffee behind Brazil, the main price setter in the coffee market. Fifth, according to Ridler, "in both size distribution and tenure system, coffee cultivation is similar in both the Ivory Coast and Colombia." ${ }^{17}$ Sixth, coffee exports are a significant source of foreign exchange for both countries. In 1989, for example, coffee exports represented 30 percent of Colombia's foreign exchange earnings and 20 percent of the earnings in Côte d'Ivoire. ${ }^{8}$ Seventh, coffee revenues impact the well-being of numerous other sectors in the Colombian and Ivoirian economies, such as transportation and food consumption.

My argument is not that these two countries are similar overall. Rather, I am simply asserting that their coffee sectors and parastatals are similar enough to merit a comparison of the two national coffee economies and how they were transformed by the changes in the international political economy of coffee. This study comparing the coffee parastatals and state-society relations in both countries will provide greater insight into the

\footnotetext{
${ }^{7}$ Neil Ridler, "The Caisse de Stabilisation in the Coffee Sector in the Ivory Coast," World Development, 16, 12 (1988), pp. 1521-1526, p. 1524.

${ }^{8}$ Special Issue: The International Coffee Agreement: A Twenty-Six Year Success Story," Colombia Today (New York, Colombian Information Service, 1989).
} 
significant impact changing global coffee market trends had on the internal dynamics of all coffee-producing countries.

\section{$\underline{\text { Coffee in Colombia and Côte d'Ivoire: Historical Contexts }}$}

The formation of the state in both Colombia and Côte d'Ivoire is often linked to the development and maintenance of coffee as an export crop. For different reasons, in both countries, the coffee sector has historically provided the economic basis for statebuilding and economic development. ${ }^{9}$

The production of Arabica coffee began in earnest in Colombia in 1865 in the region of Antioquia. In a historical overview of the political economy of coffee in Colombia, the role of FEDERACAFE is critical. Created in 1927, this organization basically has functioned almost as "a state within a state" and until very recently, has had a role to play in almost every aspect of Colombian economic life. Hartlyn describes the position of the Federation before the collapse of the ICA. It "operates as a private group when it is convenient -- serving as a pressure group for the interests of its members and as a financial conglomerate managing massive investments -- but also carries out numerous

${ }^{9}$ This argument is made by Jonathan Hartlyn and Marco Palacios regarding Colombia and by Catherine Boone and Jennifer Widner regarding Côte d'Ivoire. Jonathan Hartlyn, The Politics of Coalition Rule in Colombia (Cambridge: Cambridge University Press, 1988); Marco Palacios, Coffee in Colombia: 1850-1970: An Economic, Social and Political History (Cambridge: Cambridge University Press, 1980); Catherine Boone, "The Social Origins of Ivoirian Exceptionalism:Rural Society and State Formation," Comparative Politics, July 1995, pp.445-463; Jennifer A. Widner, "The Origins of Agricultural Policy in Ivory Coast 1960-1986," Journal of Development Studies, 29,4, pp.26-59 and "Single Party States and Agricultural Policies: The Cases of Ivory Coast and Kenya," Comparative Politics, June 1994, pp. 124-147. 
state functions related to coffee policy and also to regional development in coffee areas."10 Historically, the unique position of the Federation is due to the importance of coffee in the national economy of the country. I will explore the unique role and position of the Federation, as representative of both societal and state interests.

In Côte d'Ivoire, the production of the coffee bean began before national independence in the 1920's around the town of Guiglo. Felix Houphouet-Boigny -- who served as president of Côte d'Ivoire from its independence in 1960 to his death in 1994 -was among the first to start a coffee plantation and he remained an important coffee producer. ${ }^{11}$ He was therefore an important factor in the relations between the Ivoirian state and the coffee sector. His policies towards the coffee sector affected his personal economic interests in addition to those of the majority of small coffee producers in the country.

In 1989, following the significant drop in coffee prices, the Ivoirian government "threw open" the CSSPPA, still at that time a public entity, to private investors and let a number of them sit on its executive board; this meant that for a period the main role of the state organization would be to act as intermediary on the international markets. ${ }^{12}$ It could no longer guarantee peasants a certain price for their coffee or protect them in any way from the fluctuations on the international market. Considering the Caisse's inability to

${ }^{10}$ Hartlyn, p. 135.

11 Jeanne Maddox Toungara, "The Apotheosis of Côte d'Ivoire's Nana HouphouetBoigny, The Journal of Modern African Studies, 28, 1 (1990), pp.23-54,

12 "Country Profile: Côte d'Ivoire Mali 1993/1994," The Economist Intelligence Unit, London, p. 15. 
fulfill its primary goals, after a number of years of inaction, the government finally eliminated it in early 1999.

In short, the centrality of coffee to the economic, political and social situations of both Colombia and Côte d'Ivoire is the basic reason for which I believe a comparison of the two countries is a worthwhile enterprise. This study will enable us to draw conclusions regarding the consequences of a specific international conjuncture on two countries with very similar concerns.

\section{Data Sources}

The research methods used for this dissertation rely on both primary and secondary sources. Personal interviews of parastatal administrators and employees were conducted in Colombia and in Côte d'Ivoire at the national and local levels in 1996 and 1997. Interviews of administrators of other relevant organizations, knowledgeable informants and academics were also conducted. Coffee producers were interviewed where possible. The goal of these interviews was to get as many relevant and different perspectives as possible on the transformations in the coffee sector since 1989, with special emphasis on the roles of the parastatal agencies. In addition, I reviewed the International Coffee Agreements themselves; relevant US government, World Bank and IMF documents; and newspaper articles published on coffee in the Colombian and Ivoirian newspapers, particularly El Tiempo in Colombia and Fraternité-Matin in Côte d'Ivoire. I also reviewed official statements of national coffee policy where possible. The secondary research involved collecting and reading articles and books written by U.S., Colombian, 
Ivoirian, French and German academics on coffee and these two countries, historically and currently.

All of the information gathered enabled me to make my own arguments regarding coffee production in both countries and specifically how the parastatals have evolved through this period. These changes and the arguments I make about them shed a bit of light on the changing Colombian and Ivoirian political economies as well as the always evolving state-society relations.

\section{Overview of the Dissertation}

The dissertation begins in Chapter I with an overview of the international political economy of coffee starting in 1945 and leading up to 1997. The chapter focuses both on developments occurring between 1962 and 1989 and those taking place immediately after 1989. This focus enables me to discuss the seriousness of the disintegration of the ICA, in particular for coffee-producing countries and their coffee growers. The Western ideologies impacting international trade and economic relations through the period are also laid out as they impact both the international economy of coffee and events in the countries under study. This discussion sets the international background and context for the rest of this study.

In Chapter 2, the focus shifts to the theoretical concerns surrounding the state and coffee parastatals in Colombia and Côte d'Ivoire within the changing international political economy of coffee. Relevant bodies of theory are discussed, with particular emphasis on state-society relations. This chapter sets the theoretical parameters for the main chapters 
of the dissertation. This in-depth overview of the theoretical literature prepares us for a more specific discussion of the two countries under study here and how their coffee sectors and statal agencies have changed as a result of the end of the ICA.

Chapters 3 and 4 provide an overview of the coffee sector in Colombia, from its origins to today. Following a historical analysis of the Colombian coffee sector and specifically the role of FEDECAFE in this sector (Chapter 3), the focus shifts to the changes experienced by the Colombian coffee sector and its state agencies after 1989. I explore the situation prior to, and after, the collapse of the ICA at different levels of analysis in Colombia. I study the overall transformations within the national political economy and coffee sector resulting from the changing world economy of coffee. To the extent possible, I also provide an overview of the producers and their circumstances in these trying times. The main focus of the chapters, however, is on the parastatals as they modify their policies towards the coffee sector and the producers and how they themselves are transformed by the evolving situation. Chapters 5 and 6 review the events in the Ivoirian coffee economy in very much the same way as is done in Chapters 3 and 4 for Colombia.

Chapter 7 brings together the situations and experiences in Colombia and Côte d'Ivoire in a key comparative chapter. This chapter outlines the similarities and the differences in the two case studies with regard to their handling of the ICA's collapse and the changing circumstances in their respective coffee sectors. The comparison is strengthened by including brief overviews of several other coffee-producing countries and their experiences with the end of the ICA. This comparative analysis enables us to draw 
more general conclusions about the state of coffee-producing countries in this world. In particular, we see that the experiences of Colombia and Côte d'Ivoire do not pertain exclusively to them and that many of their economic, social and sometimes political problems were repeated in other coffee-growing countries throughout the world, regardless of geographic location. In the majority of coffee-producing countries, the parastatal agencies dealing with coffee were seriously impacted and transformed by the collapse of the International Coffee Agreement. All of this enables me to analyze the role and impact of these coffee parastatals in state-society relations and national economic development. 


\section{CHAPTER II}

\section{THE INTERNATIONAL POLITICAL ECONOMY OF COFFEE}

The fluctuations of world coffee prices over time have had and continue to have serious economic consequences for developing countries heavily dependent on the export of coffee beans. Studying developments in the coffee sector at the international level will therefore allow us to gain a more complete understanding of the political economy of coffee production and sales, along with the interconnectedness of the various levels of analysis involved. National coffee sectors thus can not be considered wholly without considering the supranational dimension of the coffee trade.

This chapter will lay out the international context that has surrounded and continues to influence the dynamics at play in the two coffee-producing countries under study in this dissertation, Colombia and Côte d'Ivoire. I will discuss both the actual events in the world coffee economy during the years covered in this chapter and the changing prominent economic ideologies that have significantly impacted the outcomes at various stages during this period. The chapter will be divided into three chronological segments: the years between the end of World War II and the first International Coffee Agreement of 1962; the years of the four International Coffee Agreements (1962-1989); and the years following the collapse of the agreements through 1997. 
Even prior to the end of World War II, the belief among leaders in the United States and its Western allies was that "a new liberal international economic order based on open markets and economic cooperation and leading to the recuperation and economic growth of the European industrial states"1 ${ }^{1}$ would be the best way to ensure prosperity after the war. A blueprint for the post-World War II plan was signed in Bretton Woods in 1944 by 44 countries. These accords established a system of fixed currency exchange rates based on the U.S. dollar, and created three existing institutions that would help the Western countries reach their goals: the International Bank for Reconstruction and Development, commonly referred to as the World Bank, which was to help countries rebuild economically; the International Monetary Fund, which was to assist countries through financial and currency crises; and the General Agreement on Tariffs and Trade, which was to promote free trade and open markets. The guiding ideology was classic liberalism. According to Gourevitch, "[it] holds that the untrammeled free market decentralized decision-making in response to the incentive for private gain - yields the greatest output and hence the greatest total wealth. Because the greatest efficiency comes from private calculations, the task of the government[s] is to leave the market alone."2

Although there was genuine American interest in the creation of this new liberal economic order, the priority for the United States was the rebuilding of its Western

1 John Spanier and Steven Hook, American Foreign Policy Since World War II (Washington, DC: Congressional Quarterly, Inc., 1998), p. 55.

${ }^{2}$ Peter Gourevitch, Politics in Hard Times: Comparative Responses to International Economic Crises (Ithaca, NY: Cornell University, 1986), p. 37. 
European allies for economic and geopolitical reasons. In conjunction with the concerned European states, the United States put forth the Marshall Plan, which would allow Europe to rebuild and the United States to export American products. Its concern over the future of the old continent was very real. The United States was not particularly interested in the situation of Third World countries at this time. In addition, some of the developing areas under discussion were still very much under the influence of their colonial powers, France in particular.

Finlayson and Zacher discuss the relationship between Northern and Southern countries following World War II specifically in the area of primary commodity trade. ${ }^{3}$ They argue that, in the immediate post-war era, the United States and its partners were not particularly concerned about the problems facing Third World nations, despite the importance of trade in primary commodities for the economies of independent Southern states and the increasing number of Southern states. They describe, for example, the negotiations in the late 1940's over the Charter of the International Trade Organization, which are of particular relevance to our discussion as one of the Charter articles put forth by Western countries deals specifically with the issue of primary commodity trade. According to Finlayson and Zacher, the charter was to state: "only in rather extreme situations of producer distress was intergovernmental action sanctioned to affect prices." ${ }^{4}$ Commodity agreements in general were not seen as a positive option for the Western

${ }^{3}$ Jock Finlayson and Mark Zacher, Managing International Markets: Developing Countries and the Commodity Trade Regime ( New York, NY: Columbia University Press, 1988).

${ }^{4}$ Finlayson and Zacher, p. 18. 
countries which laid out this Charter. With a large number of Southern countries in Havana in 1948 for the creation of the organization and a number of unresolved issues, the charter did not get signed and the organization never came about. The discussions between Northern and Southern countries with regard to primary commodity agreements ended up taking place within the United Nations or one of its specialized agencies, the Food and Agricultural Organization (FAO). It is within these agencies that discussions of the first International Coffee Agreement (ICA) took place, several years after the signing of the International Tin Agreement in 1953 and the International Sugar Agreement in 1954. Tin was produced in a relatively small number of countries such as Bolivia which were (and in some instances still are) very dependent on industrial commodities. Sugar was like coffee in the sense that it was and is produced in a large number of countries.

The cooperative international economic climate surrounding the negotiations of the first ICA and the other commodity agreements continued with the creation of UNCTAD in 1964 "and then the attempt to obtain an Integrated Programme for Commodities and from the example of OPEC in raising the earnings of oil exporting LDCs." ${ }^{5}$ This overall cooperation in the realm of primary commodities continued until the mid-1980's.

Rothstein makes a key point about international trade that is particularly valid for the coffee industry: "trade is also frequently dominated by a few large multinational corporations that control production and/or distribution and marketing - which makes a

\footnotetext{
${ }^{5}$ Christopher L. Gilbert, "International Commodity Agreements: Design and Performance," World Development, 15 (1987), 5, pp. 591-616, p. 591.
} 
mockery of the notion that the choice is between a "free" market and a regulated price." ${ }^{6}$ In the case of coffee, it is the roasting of coffee that is dominated a few large international corporations, such as Nestlé and General Foods.

Control over international coffee markets has been a goal of coffee-producing countries since the mid-1930's. Considering the relatively low international price of the bean, producing states have pursued a variety of policies to increase the world price of the commodity and thus increase their revenues. Prior to World War II, efforts to control coffee prices consisted mostly of Brazilian restrictions on coffee output and exports by decreasing sales and planting of the bean. ${ }^{7}$ Other coffee-producing states, Colombia in particular, enjoyed the benefits of Brazil's policies without having to reduce their own coffee output. This changed in 1940 with the Inter-American Coffee Agreement. It was signed by most Latin American coffee producers in Washington, DC, in an attempt to divide up among themselves the North American coffee market, since the European market had disappeared following the beginning of World War II. This Pact was abandoned at the end of the war. It is fair to say that coffee-producing countries are most interested in international commodity agreements when the prices are low but lose interest in them when the prices are high.

Following the end of the Second World War, the international price of coffee increased. Brazil's stocks of coffee were quite low as the country had lost "nearly one-

\footnotetext{
${ }^{6}$ Robert L. Rothstein, Global Bargaining: UNCTAD and The Quest For A New International Economic Order (Princeton, NJ: Princeton University Press, 1979), p. 41.

${ }^{7}$ Harmut Brandt, The Formulation of a New Coffee Agreement (Berlin, Germany: The German Development Institute, 1991), p. 66.
} 
quarter of its tree stocks between 1939 and 1945 because of a severe frost in 1943 and an unwillingness on the part of the producers to plant new coffee trees." ${ }^{8}$ In addition, as Europe started rebuilding, its citizens began purchasing coffee again. These developments encouraged parts of Africa that had until then not grown coffee to start the production of coffee in the early 1950 's. By the mid-1950's, however, the international price of coffee decreased again as Brazil's production returned to previous levels. Representatives from most of the Latin American coffee-producing countries met in October 1957 and signed the Agreement of Mexico, which was designed to maintain prices by retaining stock and instituting quarterly export quotas. In early 1958 , the price of coffee was on the rise again, only to start decreasing again later in the year. ${ }^{9}$

These first post-War years were marked by important disagreements between producer countries and consumer countries such as the United States. The latter was in favor of low prices for its domestic coffee drinkers by making "the 5 cent cup of coffee a symbol of economic prosperity." 10 The US government went so far as to subsidize the roasters and traders to keep coffee prices low for the consumer.

Despite these US actions, "a critical development in 1958 was the shift on the part of the United States from opposition to support for international action to solve coffee market problems. This policy change was largely motivated by growing fears that

${ }^{8}$ Robert H. Bates, Open-Economy Politics: The Political Economy of the World Coffee Trade (Princeton, NJ: Princeton University Press, 1997), p. 90.

${ }^{9}$ Finlayson and Zacher, p. 152.

${ }^{10}$ Bates, p. 100 . 
depressed economic conditions in Latin America would facilitate Soviet penetration of the region." 11 In June 1958, the US established, within the Food and Agriculture Organization, a Coffee Study Group to examine the opportunities for international cooperation, and the US began by negotiating the Latin American Coffee Agreement with fifteen Latin American countries.

"The participation of the United States could thus be seen as reflecting its willingness to pay economic costs - the costs of a higher price for coffee - for political benefits - the benefits of enhanced security." 12 The change of perspective of the US government seems to be in large part the responsibility of one individual, Douglas Dillon, who became Under Secretary of State for Economic Affairs in 1957 and who believed that a radical change of policy toward Latin America was needed. ${ }^{13}$ In addition, it is evident that Castro's 1959 communist takeover of Cuba, just 90 miles South of Key West, played some role in this modification of policy. Diplomatic representatives of Brazil and Colombia in Washington were also making political arguments of this nature. Even the large American roasters themselves were unable to argue against a commodity agreement for coffee because of their large and profitable contracts with Brazil and Colombia. ${ }^{14}$

${ }^{11}$ Finlayson and Zacher, p. 152.

${ }^{12}$ Bates, p. 134.

${ }^{13}$ Bart Fisher, The International Coffee Agreement: A Study in Coffee Diplomacy (New York, NY: Praeger Publishers, 1972), p. 20.

${ }^{14}$ Gregory Dicum and Nina Luttinger, The Coffee Book: Anatomy of an Industry from Crop to the Last Drop (New York, NY: The New Press, 1999), p. 89. 
Meanwhile, for a time while prices were high, several Western European countries and their colonial African governments showed no interest in cooperation. With the continued decline of the world price of coffee, however, European and African countries agreed to participate in broader international negotiations, which resulted in the signing of the first International Coffee Agreement.

Finlayson and Zacher posit the idea that, following the end of World War II, a global primary commodity regime was created. They vaguely describe regimes as "a set of regulatory arrangements developed by governments to constrain and guide their behavior and interactions in a particular issue-area." ${ }^{15}$ The issue-area of concern to these scholars is primary commodities. They view all agricultural products and natural resources and the negotiations for the agreements regulating their sales as one single large issue-area. The broad nature of this issue makes it difficult for them to detail the specifics of this supposed regime. In addition, their all-encompassing definition of a regime does not help us to narrow the subject of their study. They proffer that Northern and Southern countries have decided for different reasons to negotiate a variety of commodity agreements. The main contribution of their work is the identification of the ideological underpinnings of the negotiations, especially on the part of Northern countries.

At this point in the development of the field of International Relations Theory, I believe it would be more useful to consider the coffee agreement, for instance, as its own regime, as opposed to part of a larger regime including numerous other commodities. The definition of regimes put forth by Levy, Young, and Zürn is more helpful and more

${ }^{15}$ Finlayson and Zacher, p. 17. 
specific. For these scholars, international regimes are "social institutions consisting of agreed upon principles, norms, rules, procedures and programs that govern the interaction of actors in specific issue areas." ${ }^{16}$ As I discuss the specific clauses of the International Coffee Agreements, I will point out the particular features of the coffee regime.

\section{The International Coffee Agreements (1962-1989)}

The first International Coffee Agreement (ICA) was signed in 1962 among producers and consumers of coffee who claimed a mutual interest in the maintenance of stable coffee prices and was designed to last six years, with the possibility of renewal. The producing states were in favor of this type of agreement for obvious reasons; it would allow them to sell specified amounts of coffee at predetermined reasonable prices and world coffee prices at that point in time were low. The Western countries consuming the most coffee understood that coffee was an important export commodity for developing countries and that maintaining reasonable coffee prices might boost the development of a number of Third World states. The United States, the world's largest coffee consumer, was interested in providing assistance to the Latin American producers of the caffeinated bean, while the European consumers, especially France and Great Britain, were concerned with the economic development of the African producers. ${ }^{17}$

${ }^{16}$ Marc Levy, Oran Young and Michael Zürn, "The Study of International Regimes," European Journal of International Relations, 1995, Vol. 1(3), pp. 267-330, p. 274.

${ }^{17}$ Takamasa Akiyama and Panatoyis N. Varangis, "The Impact of the International Coffee Agreement on Producing Countries," The World Bank Economic Review, 4, 2(1990), pp. 157-173. 
George McGhee, Under Secretary of State for Political Affairs, presented the

American arguments in favor of the International Coffee Agreement before Congress. He stated:

Mr. Chairman, the achievement of this objective would be of great significance. In the first place, coffee, during the past decade, was the single most important agricultural commodity in world trade, with shipments valued in many years at over $\$ 2$ billion.

Secondly, coffee is the most important source of export earnings of Latin America and of a number of countries in Africa and elsewhere. For example, in 1961, coffee exports from Colombia accounted for 71 per cent of all foreign exchange earnings...

Thirdly, Mr. Chairman, this agreement is of great importance, because, in many areas of the world, coffee is produced by small farmers. It is estimated that about 3 to 4 million farming enterprises produce coffee, in 70 different countries.

The overwhelming majority of these farms belong to small farmers, each cultivating less than 5 acres of land. About half of all coffee is produced by farmers with 5- to 75-acre holdings.

In Latin America, coffee provides direct employment for more than 12 million persons, and we believe that this figure is in excess of 20 million in the world as a whole.

In view of the overwhelming importance of coffee as a foreign exchange earner, it is clear that the economic development of the countries in Latin America and Africa are directly related to this single crop. It has been shown that a decrease of 1 cent per pound for green coffee means a decrease of about $\$ 50$ million in the foreign exchange receipts of the Latin American countries.

Obviously, the tremendous effort that we are making under the Alliance for Progress is endangered, and the large sums appropriated to assist economic development are canceled out to the extent that earnings from the principal export commodity fluctuate sharply or decrease steadily. Stability in foreign exchange earnings can be the firm foundation for our sustained efforts to help these countries help themselves. ${ }^{18}$

${ }^{18}$ Statement of Honorable George C. McGhee, Hearing Before the Committee on Foreign Relations, United States Senate, Eighty-Eighth Congress, March 12, 1963, p. 42. 
This declaration outlines the US reasons for supporting this agreement; it clearly indicates that the United States executive branch was pursuing this agreement for the benefit of the Latin American countries and their farmers.

Members of Congress saw clearly the benefits of the Agreement for coffeeproducing countries but asked a number of questions regarding the benefits to the American consumer. McGhee responded to their concerns by citing the consumers' stakes in the continued production of coffee. If prices of the bean got extremely low, Latin American and African farmers would no longer be interested in coffee production and this could have devastating effects on the American consumers: very high coffee prices or scarcity of coffee. ${ }^{19}$

It is worth noting who the members of the International Coffee Agreement were. They included most of the large European and North American consuming countries as well as the majority of producing countries. According to Bates and Lien, the European and North American countries in the organization represent 95 per cent of annual coffee consumption and the producer countries which are not members each produce less than 100,000 bags of coffee annually. ${ }^{20}$ This leads us to one of the features of the international coffee regime. It involves functional differentiation as it brings together producers and consumers of the bean.

${ }^{19}$ McGhee, p. 60.

${ }^{20}$ Robert H. Bates and Da-Hsiang Donald Lien, "On The Operations of The International Coffee Agreement, " International Organization 39, 3 (Summer 1985), pp.553-559, p. 554. 
Beyond the natural distinction between the consumer and producer nations

members of the ICA, there are also significant differences among the coffee-exporting countries. "Some countries produce large and others small quantities; some are long standing exporters others comparative newcomers; some produce Arabicas others Robustas." ${ }^{21}$ In general, there seem to be two groups of producers: Latin American countries (which produce large quantities of Arabica coffee, have been exporting it for many years and enjoy proximity to the US) and African countries (which have not been producing Robusta coffee for that long and are also closer politically closer to the European countries). ${ }^{22}$

With these nuances in mind, let us review some of the important clauses of the first International Coffee Agreement of 1962, which make up the rules of the regime. The official goals of the ICA, as listed in Article 1, were the following:

(1) to achieve a reasonable balance between supply and demand on a basis which will assure adequate supplies of coffee to consumers and markets for coffee to producers at equitable prices, and which will bring about longterm equilibrium between production and consumption; (2) to alleviate the serious hardship caused by burdensome surpluses and excessive fluctuations in the prices of coffee to the detriment of the interests of both producers and consumers; (3) to contribute to the development of productive resources and to the promotion and maintenance of employment and income in the Member countries, thereby helping to bring about fair wages, higher living standards, and better working conditions; (4) to assist in increasing the purchasing power of coffee-exporting countries by keeping prices at equitable levels and by increasing consumption; (5) to encourage the consumption of coffee by every possible means; and (6) in general, in recognition of the relationship of the trade in coffee to the economic

${ }^{21}$ James Mwandha, John Nichols and Malcolm Sargent, Coffee: The International Commodity Agreements (Brookfield, VT: Gower Publishing Company, 1985), p. 109.

${ }^{22}$ Mwandha, p. 109. 
stability of markets for industrial products, to further international cooperation in connection with world coffee problems. ${ }^{23}$

Although the language used in this first article leads us to believe that it is in the economic interest of both the producing and consuming countries to be part of the agreement, it is still quite obvious that it is primarily in the economic interests of the producing countries to participate in the agreement. As discussed earlier, the large consuming countries had other aims in mind. It is hard to argue that on the consumer side fluctuations in the price of coffee would cause "serious hardship" to anyone. The "burdensome surpluses" are also exclusively a phenomenon of the producer countries.

The ICA set up a structure and procedures to implement and administer the agreement. The International Coffee Organization was established by Article 7 of the ICA and was to be based in London, United Kingdom. It is there that representatives of the member countries met and meet to negotiate quotas and coffee agreements. "This organization will administer the provisions of the agreement and supervise its operation."24 The International Coffee Council shall be the highest authority of the organization and shall be made up of all the members of the organization (Article 8). To pass a resolution, the Council needs a vote of two-thirds of its members (Article 9). Separately, the exporting and importing members will hold a total of 1,000 votes. The number of votes

${ }^{23}$ The International Coffee Agreement of 1962, as reproduced in the Appendixes of: Thomas Geer, An Oligopoly: The World Coffee Economy and Stabilization Schemes (New York, NY: Dunnellen Publishing Company, Inc., 1971), pp. 191-312.

${ }^{24}$ Geer, p. 198. 
per country will be adjusted each year depending on the number of countries involved. No single member shall hold more than 400 votes.

The ICA of 1962 set the basic export quotas for the following 3 years as well as the mechanisms to adjust these export quotas (Article 28). Table 1 provides a representative sampling of the export quotas assigned to exporting countries.

Table 1: Basic Export Quotas for Small Group of Coffee-Exporting Countries (60 kilogram bags)

$\begin{array}{lr}\text { Country } & \text { Export Quota } \\ \text { Brazil } & 18,000,000 \\ \text { Colombia } & 6,011,280 \\ \text { Congo (Brazzaville) } & 11,000 \\ \text { Costa Rica } & 950,000 \\ \text { India } & 360,000 \\ \text { Indonesia } & 1,176,000 \\ \text { Ivory Coast } & 2,324,278 \\ \text { Mexico } & 1,509,000 \\ \text { Trinidad } & 44,000 \\ \text { Uganda } & 1,887,737 \\ \text { Venezuela } & 475,000\end{array}$

Source: Geer, p. 243.

Exporting members are required by Article 33 to notify the Council of the ICO if they will not be able to meet their quota for a given year. The Council may then decide to make changes in the export quotas of other countries in order to make up for the unmet quota. One of the most interesting articles in the ICA is Article 40 and its subparagraph (f).

In order to facilitate the increase of coffee consumption in certain areas of the world having a lower per capita consumption and considerable potential for expansion, exports to countries listed in Annex B shall not, subject to the provisions of sub-paragraph (f) of this paragraph, be charged to quotas....... (f) If coffee exported by a Member to a country listed in Annex B is re-exported to any country not listed in Annex B, the Council shall charge the corresponding amount to the quota of that exporting Member. Should there again be a re-exportation from the same country listed in Annex B, the Council shall investigate the case, and unless it finds 
extenuating circumstances, may at any time delete that country from Annex B. ${ }^{25}$

The list of countries in Annex B was not particularly short. They were: Bahrain, Basutoland, Bechuanaland, Ceylon, China (Taiwan), China (Mainland), Federation of Rhodesia and Nyasaland, Hungary, Iran, Iraq, Japan, Jordan, Kuwait, Muscat and Oman, Oman, Philippines, Poland, Qatar, Republic of Korea, North Korea, Republic of Vietnam, North Vietnam, Romania, Saudi Arabia, Somalia, Southwest Africa, Sudan, Swaziland, Thailand, Republic of South Africa, and Union of Soviet Socialist Republics. ${ }^{26}$ Article 40 sought to accomplish a number of goals. First, it was trying to allow producing countries to export a little more than their quota. Second, it was meant to encourage an increase in per capita consumption for the countries in Annex B which consumed very little coffee. In trying to reach those goals, the ICA did not want to allow for the possible use of these Annex B countries by producer countries to circumvent export quotas in search of more, this time extra-regime, exports. By allowing for the numerous Annex B countries to exist as a category at all, the ICA was however setting itself up for exactly the types of problems it was seeking to avoid. It is also worth noting that numerous countries in Annex B were countries belonging to the Soviet sphere of influence. It would be hard for the ICO, primarily a Western endeavor, to find out how much coffee was entering and departing these sometimes very large countries.

\footnotetext{
${ }^{25}$ Geer, p. 218.

${ }^{26}$ Geer, p. 245.
} 
Article 44 set up certificates of origin and re-export which would allow the

International Coffee Organization to keep track of exports and imports. Since export quotas were such a big part of the ICA, this is an important article.

Every export of coffee from any Member in whose territory that coffee has been grown shall be accompanied by a certificate of origin modelled on the form set forth in Annex C, issued by a qualified agency chosen by that Member. Each such Member shall determine the number of copies of the certificate it will require and each copy shall bear a serial number. The original of the certificate shall accompany the documents of export, and a copy shall be furnished to the Organization by that Member. The Council shall, either directly or through an internationally recognized world-wide organization, verify the certificates of origin, so that at any time it will be able to ascertain the quantities of coffee which have been exported by each Member. $^{27}$

Article 46 of the ICA set out goals for the worldwide promotion of coffee, seeking to increase consumption. The French argued for the inclusion of this goal in the agreement. However, no particular funds were allocated to carry out this goal.

The last article worth mentioning is Article 48. It states that the International Coffee Council will set annual production goals for each producing country and the world as a whole. It specifies however that it is up to each country to decide how it will reach that production goal.

The existence and maintenance of the International Coffee Agreement is in large part dependent upon the interest and involvement of the large coffee-consuming countries, the United States in particular. Three issues are important for the continued support of the consumer countries: the determination of an acceptable price range, the rules

${ }^{27}$ Geer, p. 220. 
governing the quotas, and the enforcement mechanisms put in place. ${ }^{28}$ The effectiveness of the agreement did in fact lie in the hands of the consuming countries by means of their customs agents. They were to $\log$ in the coffee shipments received and indicate amount and origin. This information was then provided to the International Coffee Organization, which kept track of exports and imports.

The setting of acceptable export quotas and price ranges for the producing and consuming countries was one of the important and difficult parts of the implementation of the agreement. According to Araim, "the quota system was aimed at controlling the exports and prices of coffee for the benefit of producers and consumers." ${ }^{29}$ The setting of these export quotas was the main source of disagreement among the countries participating in the negotiations for the ICA as is the case in most commodity negotiations. In this instance, "the main adversaries were Brazil and Colombia on the one hand, and the Africans on the other. The former had seen their market positions suffer because of recently expanded African production, and thus wanted quotas to be based on historical production trends. The latter insisted that quotas reflect potential production... In the end, the Brazil-Colombia view was accepted." ${ }^{30}$ Throughout the short history of the coffee agreements, quotas would continue to be a difficult issue.

${ }^{28}$ Finlayson and Zacker, p. 14.

${ }^{29}$ Amer Salih Araim, Intergovernmental Commodity Organizations and the New International Economic Order (New York, N\Y: Greenwood Publishing Group, 1991), p. 195.

${ }^{30}$ Finlayson and Zacher, p. 154. 
How would all these issues play out in the actual implementation of the first agreement and how would they effect the negotiation of the subsequent agreements? I will now turn to the actual events in the coffee sector during this period.

The first International Coffee Agreement went into effect in 1963. Ironically, the first issue the signatories faced was a significant rise in the price of coffee. Producing countries realized that to maintain the commitment of consuming countries, they would also have to agree to price ceilings. Following a subsequent price decrease in 1964, the producers and consumers were finally able to agree on an international price range for coffee, $38-44$ cents per pound. ${ }^{31}$ They had been unable to do this when they first negotiated the agreement.

In the mid-1960's, there was disagreement on the enforcement system between some of the consumers and larger producers and the smaller ones. Three enforcement problems stand out: 1) direct overshipment of export quotas by member producers to member consumers; 2) use of Annex B countries for shipment from member producers to member consumers; and 3) shipment of coffee from member producers to member consumers through non-member non-Annex B countries. ${ }^{32}$ As large producing countries, Brazil and Colombia understood quite clearly that to maintain prices and the ICA, they needed to stay within their assigned quotas. The African countries, however, among others, were using the loopholes in the agreement to export more coffee; they were also unhappy with the selection process involved when a producer could not meet its annual

\footnotetext{
${ }^{31}$ Finlayson and Zacher, p. 156.

${ }^{32}$ Fisher, p. 81.
} 
quota. After resolving these issues to everyone's reasonable satisfaction, the enforcement system was much stronger as was the agreement as a whole.

The difficulties encountered with the enforcement of the agreement originated in large part with the fact that no international mechanism was in place to control coffee production in the various producing countries. ${ }^{33}$ According to Mwandha, "the result was to encourage production (relative to requirements for allotted exports and domestic consumption) in amounts and locations which have varied from one coffee year to another."134

The 1967 negotiations for the second International Coffee Agreement dealt with some of the problematic issues encountered during the years of the first ICA. Specifically, a new article 37 was added:

(1)...the Council shall seek to ensure that: (a) supplies of the types of coffee that consumers require are available to them; (b) the prices for the different types of coffee are equitable; and (c) sharp price fluctuations within brief periods do not occur. (2) To achieve these objectives the Council may, notwithstanding the provisions of Article 36, adopt a system for the adjustment of annual and quarterly quotas in relation to the movement of the prices of the principal types of coffee. The Council shall annually set a limit not exceeding five per cent by which annual quotas may be reduced under any system so established. For the purposes of such a system the Council may establish price differentials and price brackets for the various types of coffee. In so doing, the Council shall take into consideration, among other things, price trends. ${ }^{35}$

\footnotetext{
${ }^{33}$ Mwandha, p. 113.

${ }^{34}$ Mwandha, p. 113.

${ }^{35}$ Geer, p. 275.
} 
In addition, in response to the overproduction problem mentioned previously, an international Diversification Fund sponsored by the ICA was created to assist the producer countries in the long-term diversification of their economies and the reduction of dependence on the green bean (Article 54). Brazil and Colombia lobbied for this fund and the United States supported this initiative. Sixty cents was to be levied on each exported bag of coffee beyond 100,000 bags. ${ }^{36}$ This fund was to encourage the coffee industry as a national engine of growth for the producing countries and to set aside funds for the next step in their development. The creation of the fund is a good indication that consumers and large producing countries did not view coffee as an eternal part of the economies of developing countries.

One year after the beginning of the second ICA, international coffee prices rose dramatically in response to weather damage to the Brazilian coffee crop. Despite the inherent mechanisms in the ICA and the additional negotiations which took place among consumers and producers (including disagreements among producers), it was not possible to maintain price ceilings and export quotas. The 1971 devaluation of the dollar only made the situation more complicated as all the values in the agreement were denominated in dollars. Producers requested a four per cent increase for all coffee prices. The United States and Canada vetoed the idea and this pushed most of the Latin American and African producers of coffee to create their own producer forum called the "Geneva Group." This group never really got off the ground as news of a frost in Brazil caused world coffee prices to increase across the board by approximately 25 per cent. Again,

${ }^{36}$ Fisher, p. 129. 
high prices had stymied efforts to forge a producer cartel. These events and the resulting tension between producers and consumers, as described by Finlayson and Zacher, led to the collapse of the second ICA in 1973, one year before its planned expiration. ${ }^{37}$

Although meetings were held throughout 1973 and 1974, it was not until late in 1975 that producers and consumers met again to discuss a third ICA. By this time, Brazil had suffered the worst freeze in its history and coffee prices had jumped by fifty per cent in just a few days. Although the producer countries were enjoying high prices, their representatives were aware of the fact that this would not always be the case and that quotas would be necessary again when prices came back down. In addition, the increasing number of coffee-producing countries would make negotiations more difficult.

On the consumer side, there was a bit of reluctance in thinking about joining another International Coffee Agreement when the previous one had been terminated under such appalling circumstances. According to Finlayson and Zacher, "however, the United States, France and to a lesser extent other Western countries remained sympathetic to the idea of a safety net for Latin American and African producers' export earnings, and hoped to promote greater economic and political stability in these regions. In addition, they wanted to lend some support to existing ICAs in the face of UNCTAD's recent attempts to expand its powers vis-a-vis such arrangements through the Common Fund scheme."18

The third International Coffee Agreement was in some ways simpler than its two predecessors. The economic clauses of the agreement would only be in effect between

${ }^{37}$ Finlayson and Zacher, pp. 158-159.

${ }^{38}$ Finlayson and Zacher, p. 160. 
certain agreed upon price levels. The quotas were to resume following the Brazilian frost when the price was equal to or below 77 cents per pound. ${ }^{39}$ The calculation of a country's quota was also simplified. The quota was to be determined at 70 per cent by the country's exports over the last four years and at 30 per cent by the country's stocks.

This new ICA went into effect in October 1976. However, its economic clauses did not go into effect until Brazil resumed its normal production in 1979 after having replanted its coffee trees. World coffee prices were too high until then. In 1976, prices rose from $\$ 1.00$ to $\$ 2.00$ per pound; they then reached their highest point in Spring 1977 at $\$ 3.40$ per pound. ${ }^{40}$ Larger coffee producers, such as Colombia and Côte d'Ivoire, profited greatly from Brazil's misfortune.

Negotiations for the fourth International Coffee Agreement began in 1982. It was clear at this point that tensions were high among different groups of producer countries. The issue of national quota assignments had always been one of the key issues in all coffee negotiations but it became even more so with more countries producing coffee and joining the agreement. Despite the disagreements, all the producer countries felt that leaving the agreement was not an option as the cost of doing so would be too high.

In particular, Colombia's export quota in this fourth ICA was increased, on the one hand as a result of its increased production and, on the other, because of a projected increase in worldwide demand for its high-quality coffee. The United States supported

\footnotetext{
${ }^{39}$ Gilberto Arango Londoño, Por Los Senderos del Café: De La Gran Bonanza a la Peor Crisis, 1975-1993 (Bogotá, Colombia: Ediciones Fondo Cultural Cafetero, 1994), p. 37.

${ }^{40}$ Finlayson and Zacher, p. 161.
} 
this increase in the Colombian export quota. This increase took place at the expense of a number of smaller producers, such as Uganda, Ethiopia and Indonesia and leads analysts such as Finlayson and Zacher to describe the International Coffee Agreement "as a kind of consumer-sanctioned producer cartel." ${ }^{41}$

From the perspective of economists such as Akiyama and Varangis, the export quotas set up by the ICAs over the years were particularly beneficial for large producers such as Brazil, Colombia and Côte d'Ivoire. These authors state: "the distribution of the quota system for the period 1981-1985 favored exporters that were large and/or were traditionally assigned high quotas." ${ }^{42}$ Colombia and Côte d'Ivoire were not only large producers, they were also able to maintain reasonably high quotas.

It is important to note a key change in world coffee production between the early 1960 's and the mid-1980's. Overall, the share of world production of Latin American countries had declined while that of Africa and especially Asia had increased. This explains both the growing number of countries joining the ICO and the ICA and the escalating difficulty in quota negotiations.

At the end of 1985, news of a drought in Brazil caused the international coffee prices to soar again. By April 1986 , the price was $\$ 2.40$ whereas the range discussed in the international agreement was between $\$ 1.20$ and 1.40. Prices did not remain high for very long, however, as they were back to $\$ 1.20$ by February 1987 . Disagreements were numerous regarding the re-entering of the quota system. The consumers were in favor of

\footnotetext{
${ }^{41}$ Finlayson and Zacher, p. 162.

${ }^{42}$ Akiyama and Varangis, p. 172.
} 
a new system of quota distribution while most producers were in favor of the old system with a few minor modifications. A compromise was reached that, for one year, the old system would be enforced and that, for the following year, the new system proposed by the consumers would be implemented. It seems that the obstacles to the maintenance of the agreement kept getting higher and more numerous.

It was thus not entirely surprising that, in 1989 , the seventy-four members of the International Coffee Organization (ICO) were unable to agree on the terms of a new International Coffee Agreement, thus ending the twenty-six years of relative stability in world coffee markets. The issues which brought the negotiations of a new coffee agreement to a grinding halt were both varied and numerous. They involved disagreements between Brazil and certain Central American and Asian states over the size of the Brazilian export quota; Brazil was completely unwilling to give up any of the extremely large export allotment provided to it by the International Coffee Agreements, namely 31 percent. Also, the increasing importance of multinational corporations in the processing of the coffee and their growing influence on the US government made the United States less of a proponent of these agreements; the multinationals were in favor of free-floating prices and supplies of coffee beans. ${ }^{43}$ Many of these problems among the signatories of the ICAs did not just surface in 1989, but had been growing in importance since the mid-1980's.

${ }^{43}$ For a more complete discussion of these issues, please see John Talbot, "Regulating the Coffee Commodity Chain: Internationalization and the Coffee Cartel," Berkeley Journal of Sociology, 40 (1995-96), pp. 113-148. 
Talbot provides us with more global reasons for the breakdown of the coffee agreements, such as changes in the international political economy of coffee and the internationalization of coffee production. Talbot argues that the increasing importance of multinational corporations in consuming countries has had a tremendous impact on the international politics of coffee. He argues, however, that the "take-over" of the coffee markets by multinational corporations has taken place almost exclusively on the Western end of coffee processing, distribution and sales. The Southern countries producing the coffee have remained relatively untouched by this globalization phenomenon. "Coffee is still a labor-intensive crop produced mainly by peasants and small farmers in most countries, using methods that have changed relatively little since the 1950s." ${ }^{44}$ The key point to be made, however, is that although the production process of the bean may remain relatively unchanged in Southern countries, the events taking place on the world coffee markets very much affect the political economies of these Southern countries and the lives of the small producers in these countries.

From the description of the negotiations for the various International Coffee Agreements and the price fluctuations during the years of the agreements, it is obvious that the ICA was far from bringing complete stability to the coffee producers or the coffee markets. I do believe, however, that the agreements assisted in reducing the economic instability existing in this sector for developing economies. As we will see in the next section of this chapter and Chapters 4 and 6 , the collapse of the ICA was a much more significant event than anticipated.

${ }^{44}$ Talbot, p. 125. 
What has happened to the world coffee markets since 1989? I will begin by focusing on specific events and linkages taking place in the world coffee sector in the first few years following the collapse of the ICA. From there, I will move to a discussion of the general tendencies at work in the world political economy which influenced and continue to impact sectors such as the coffee industry.

The end of the ICAs brought with it first an immediate decrease in market prices. In the two years following the end of the ICAs, the price of coffee on the world market dropped by 50 percent. ${ }^{45}$ Specifically, in the first trimester of 1992 , the world price of coffee was half of the 1988 average. ${ }^{46}$ The price of coffee in the early 1990 's was the lowest it had been in 50 years and remained at historic lows for five years. ${ }^{47}$ According to Dicum and Luttinger, "in the producing countries, the party was over."148

A number of factors were affecting coffee prices on the world markets. Many producing countries, including Colombia and Côte d'Ivoire, decided to take advantage of the liberalization of the coffee sector to sell their significant surplus stocks on the world market. At the end of 1988, 47 million sixty-kilo bags of coffee were being stored around the world and, following the collapse of the ICA, 11 million of those bags were exported

${ }^{45}$ Talbot, p. 134.

${ }^{46}$ Takamasa Akiyama and Panos Varangis, "Perspectivas del Mercado Mundial del Café" in Economia Cafetera: Crisis y Perspectivas edited by Pontificia Universidad Javeriana Departamento de Planeacion (Bogotá, Colombia: Centro Editorial Javeriano, 1993), pp. 13-34, p. 15.

${ }^{47}$ Dicum and Luttinger, p. 95.

${ }^{48}$ Dicum and Luttinger, p. 95. 
by producer countries. ${ }^{49}$ Paying for the storage of coffee bags was expensive for many countries and there was at this point no reason to maintain large stocks. In addition, if a new ICA had come about during this period, many of these countries would have argued for larger quotas based on their increased exports. This "dumping" on the part of producing countries of course meant that large amounts of coffee could be bought cheaply by Western processing companies. For the several years following the collapse of the coffee agreement, there was more coffee for sale on the market than was demanded by consumers.

This crisis was made more severe by the extremely slow capacity of production to respond to international low demand..$^{50}$ Despite the extremely low prices, world production of coffee actually reached an all-time high between 1990 and 1991 . Because the coffee plant is a tree which requires four years or more before it produces coffee beans, it is not like other crops which can be planted or not each year. In addition, a number of countries, Colombia in particular, had been encouraging their farmers to plant more productive types of coffee. The governments of many coffee-producing countries also lowered their exchange rates and export taxes to diminish the impact of the crisis on the producers themselves, thus giving them less incentive to quit the production of coffee.

At the same time as world production reached unprecedented highs, the uprooting of trees in a number of countries including Brazil and Colombia also became common

\footnotetext{
${ }^{49}$ Akiyama and Varangis, Economia Cafetera, p. 15.

${ }^{50}$ Akiyama and Varangis, Economia Cafetera, p. 15.
} 
practice in an attempt to reduce the losses incurred each and every day. ${ }^{51}$ This systematic removal of trees had never been seen or encouraged in these countries in the long history of coffee production.

At this time, there was a decrease in the world demand for coffee as a result of a general recession in a number of the consuming countries. The former Soviet Union, in particular, significantly reduced its coffee imports from 2.7 million bags in 1989 to 1.2 million bags in 1990 and 1 million in 1990..$^{52}$ The Soviet Union had been importing one third of Brazil's instant coffee exports and half of India's total coffee exports. The Indian coffee sector was obviously seriously affected by these changes in Soviet imports.

The prices of coffee per pound in the consumer countries were only slightly affected by the collapse of the coffee agreements. Although the price of coffee on the international markets decreased 40 per cent, individual consumer prices only decreased by 5-7 per cent in most consumer countries as the world price of the coffee bean is only a small component of the consumer price, 26 per cent for example in the United States. ${ }^{53}$ Consumer countries as a whole increased their stocks of coffee to take advantage of the cheap prices. The coffee in storage in consuming countries increased from 8.5 million bags at the end of 1988 to 17 million at the end of $1991 .^{54}$

${ }^{51}$ Dicum and Luttinger, p. 102.

${ }^{52}$ Akiyama and Varangis, Economia Cafetera, p. 25.

${ }^{53}$ Akiyama and Varangis, Economia Cafetera, p. 18.

${ }^{54}$ Akiyama and Varangis, Economia Cafetera, p. 18. 
On the world markets, the price differential between the Robusta and Arabica types of coffee increased during this time. Arabica coffee beans provide the rich and wonderful flavor we enjoy in coffee. These beans are generally of higher quality and thus more expensive than Robusta beans. Prior to the collapse of the agreement, the difference in price between the two varieties had been between 4 and 20 per cent. At the beginning of the 1990 's, the differential increased to 40 per cent. The rapid increase in the world production of Robusta and the consumer preference for arabica coffee are at the origin of this price differential.

It is worth observing the changes in coffee income for the producing countries during this period (Table 1). The incomes decrease across the board starting in the 1988/1989 coffee year.

Table 2: Income from coffee exports for some coffee-exporting countries from 1985 to 1991 (in millions of dollars)

Coffee Year

$\begin{array}{lrrrr}\text { All ICO countries } & 8882 & 9162 & 6623 & 6488 \\ \text { Brazil } & 2165 & 1878 & 1221 & 1568 \\ \text { Colombia } & 1525 & 1720 & 1401 & 1386 \\ \text { El Salvador } & 322 & 283 & 261 & 212 \\ \text { Mexico } & 404 & 531 & 430 & 385 \\ \text { Ethiopia } & 267 & 258 & 170 & 118 \\ \text { Cameroon } & 197 & 167 & 155 & 114 \\ \text { Côte d'Ivoire } & 515 & 375 & 291 & 309 \\ \text { Kenya } & 241 & 267 & 207 & 194 \\ \text { India } & 202 & 244 & 176 & 137 \\ \text { Indonesia } & 518 & 596 & 356 & 375\end{array}$

Source: Akiyama and Varangis, p. 17. (from International Coffee Organization)

Many producing countries, including Colombia and Côte d'Ivoire, were in favor throughout the period of renewing negotiations among producers and consumers, resolving the issues on which there was disagreement, and signing a new International 
Coffee Agreement. Government leaders in both countries were very active in trying to renew the negotiations for a new agreement. Their efforts, however, were not rewarded.

Following the collapse of the ICAs, many of the coffee-producing countries, including Brazil, El Salvador, and Nicaragua eliminated the stabilization funds which regulated coffee prices and exports. It would therefore be difficult to regulate coffee exports in those countries. In addition, the changes in coffee exports of the producer countries since 1989 would make quota negotiations particularly difficult. ${ }^{55}$

With time, the producing states began negotiations for the creation of a producer cartel of sorts that would work to increase and stabilize the prices of the commodity under study and substantially ameliorate the economic situations of the producer countries. They signed an agreement to this effect in Kampala, Uganda on August 17, 1993, and created the Association of Coffee Producing Countries. ${ }^{56}$ All the members of this new organization agreed to reduce their possible exports by 20 percent in an effort to force an increase in the price of coffee..$^{57}$

Their hopes of a new ICA ever being signed completely disappeared when, following the meetings in Kampala, the United States withdrew its membership from the International Coffee Organization as a whole at the end of September 1993. According to Brooke, this step drove a "coffin nail into the 30 -year-old consumer and producer

\footnotetext{
${ }^{55}$ Akiyama and Varangis, p. 28.

56 "Cartel Begun on Coffee", The New York Times, August 18, 1993, p. D2.

${ }^{57}$ Talbot, p. 34.
} 
forum." ${ }^{58}$ This move was particularly important in the history of the ICAs because the United States is by far the largest consumer of coffee in the world. The withdrawal of the United States as a member basically meant the complete disarray of the International Coffee Organization.

In 1994, coffee prices finally began increasing again. Multiple frosts in Brazil in combination with the actions of the producer cartel are the main developments allowing the price rise. Prices of coffee in the mid to late 1990's were higher than they were in 1990 but were not providing the majority of producing countries with the economic engine they needed.

It is not by chance, however, that no agreement could be reached by the members of the International Coffee Organization in the 1989 negotiations for a new ICA. Yes, the factors mentioned by Talbot and others had an important impact on the collapse of the coffee agreements. However, there are also underlying ideological and political currents which have not been mentioned thus far and which had significant consequences for the way in which the consuming countries in particular negotiated in 1989. The Soviet Union was on the verge of collapse. The fear that had guided the United States, in particular, towards the negotiations of the first ICA quickly evaporated. In addition, the industrial countries individually as well as international organizations such as the World Bank and the International Monetary Fund were in the midst of changing their ideologies and thus their economic priorities. The International Coffee Agreement and other agreements like

${ }^{58}$ James Brooke, "A New Coffee Cartel Tries Its Hand," The New York Times, October 3, 1993, Section 3, p. F11. 
it did not assist in the setting of these new goals; on the contrary, they ran precisely counter to the very principles and ideas of the new economic ideology, neoliberalism. The circumstances surrounding the regime had changed and the regime collapsed.

What are the main principles espoused by neoliberalism? The main underlying ideas are that the role of the state in the economic affairs of a given country should be reduced and that markets should be allowed to function with as little interference as possible. Many scholars discuss neoliberalism and its impact on given societies without defining it specifically. Williamson, however, puts forth for us the main principles of neoliberalism as embodied in the "Washington Consensus (the perspective of the United States government and the international financial institutions located in Washington, DC)." ${ }^{59}$ These neoliberal ideals include, among others: fiscal discipline, tax reform, trade liberalization, a reduction in overall public expenditures and the privatization of state enterprises. ${ }^{60}$ These goals, in their implementation, will have an important impact on the coffee-producing countries under study in this dissertation. Since the state has played a central role in the coffee industry of both Colombia and Côte d'Ivoire, the impact of neoliberalism on the state's institutions will also impact the coffee sector as a whole, both directly and indirectly.

Neoliberalism has brought with it the liberalization of the world economic order in a way not unlike what the United States and its Western allies were seeking at the beginning of the post World War II era and is the ideological backdrop for the collapse of

\footnotetext{
${ }^{59}$ John Williamson, "Democracy and the Washington Consensus," World Development, 21, 8 (1993), pp.1329-1336.

${ }^{60}$ John Williamson, pp.1332-1333.
} 
the International Coffee Agreements. It will thus pervade the presentation and analysis of events and changes in Colombia and Côte d'Ivoire after 1989.

\section{$\underline{\text { Conclusions }}$}

In this chapter, I have laid out the important events in the international political economy of coffee between 1945 and 1997 and described the International Coffee Agreements, the negotiations leading up to them and the key clauses of the four agreements. I also discussed the political and ideological background which surrounded and affected the world coffee economy throughout the period.

Globally, coffee is a key commodity for many Third World countries. The income earned from the export of the bean makes up a significant portion of their income and foreign exchange earnings. Changes in the world prices of coffee thus have a direct and dramatic impact on the economies and the citizens of coffee-producing nations. It is the very centrality of coffee in the political economy of numerous developing societies which convinced the Western allies to participate in negotiations for the International Coffee Agreement.

It is obvious that the ICAs were not perfect and did not solve all the economic problems facing coffee-producing states. The agreements, however, alleviated their burden and allowed them more stable incomes than previously.

The role of the United States in the launching and the collapse of the coffee agreements cannot be neglected. The changes in US policy during this time had a direct impact on the outcome with regard to the ICAs and coffee-producing nations. In addition, 
there is a close relationship between US foreign policy and the ideologies prevailing over events at different stages of the discussion.

This overview of the coffee trade at the international level provides us with the necessary background for the forthcoming description and analysis of the evolution of two specific national coffee sectors, the Colombian and the Ivoirian ones. The interconnectedness of the various levels involved in the coffee industry make it key to have an understanding of events at the international level.

The content of this chapter will thus deepen and enrich the analysis of the case studies in this dissertation. Before discussing Colombia and Côte d'Ivoire in detail, it is important to present some of the theoretical issues at the core of this study. 


\section{CHAPTER III}

\section{THEORETICAL CONSIDERATIONS}

The international political economy of coffee discussed in the previous chapter has a causal relationship with the coffee sectors of numerous developing countries, as this dissertation will show. Price fluctuations at the supranational level impact coffeeproducing nations in numerous ways, described by George McGhee for the US Congress. The GNP of the developing nation decreases affecting its economy across the board; on a more local level, coffee farmers earn less and search for ways to decrease the costs associated with coffee production.

Numerous scholars have focused on these two areas of study. Economists have analyzed the consequences of relying on commodity export crops for national economies and economic development. ${ }^{1}$ Anthropologists and sociologists have researched coffee producers, their varying situations and options on a personal and group level. ${ }^{2}$

Although this dissertation will discuss in general terms the consequences of the International Coffee Agreement's collapse on the national economies and coffee farmers of Colombia and Côte D'Ivoire, the focus of this study will be on an area that has not been

\footnotetext{
${ }^{1}$ For example: F. Gerard Adams and Jere R. Behrman, Commodity Exports and Economic Development (Lexington, MA: Lexington Books, 1982) and Theophilos Priovolos, Coffee and The Ivory Coast: An Econometric Study (Lexington, MA: Lexington Books, 1981).

${ }^{2}$ For instance: Sutti Ortiz, Harvesting Coffee, Bargaining Wages: Rural Labor Markets in Colombia, 1975 - 1990 (Ann Arbor, MI: The University of Michigan Press, 1999) and Deborah Sick, Farmers of the Golden Bean: Costa Rican Households and the Global Coffee Economy (DeKalb, IL: Northern Illinois University Press, 1999).
} 
studied in depth by academics: the coffee parastatals which exist in many coffee-producing states and provide direction and control to their coffee sectors. How have they been impacted by the changes in the international political economy of coffee? Did they survive? How did they transform themselves? Who led the changes? These questions will enable us to understand more clearly the role of these quasi-state agencies in the national coffee sectors and in development.

This cross-regional study of agricultural parastatal organizations places itself in a web of different theoretical and regional literatures that do not speak directly to one another. This chapter seeks to explore the various relevant perspectives put forth in the academic literature on the general definition, role and position of these types of organizations in developing countries; it will also lay out possible outcomes for these institutions during and after international crises which affect them directly. The historical context surrounding the creation of these quasi-state agencies in various parts of the world will also be discussed.

It is important to begin with issues of terminology. To what am I referring when I use the word "parastatal"? Parastatals can be defined in institutional or functional terms. The definitions available in the scholarly literature seem to address mostly the institutional aspect of the parastatal. For example, Aharoni views the term parastatal as synonymous with state-owned enterprise (SOE). ${ }^{3}$ He defines SOES by their "public" nature, by their "enterprise" status, and by the prices charged for their services, admitting that each

\footnotetext{
${ }^{3}$ Yair Aharoni, The Evolution and Management of State Owned Enterprises (Cambridge, MA: Ballinger Publishing Company, 1986), p. 6.
} 
World defines a parastatal as an organization which:

- $\quad$ is owned by public authorities to the extent of fifty percent or more;

- $\quad$ is under the top managerial control of the owning public authorities, such as public control, including inter alia, the right to appoint top management and to formulate critical policy decisions;

- $\quad$ is established for the achievement of a defined set of public purposes, which may be multidimensional in character;

- $\quad$ is engaged in activities of a business character;

- $\quad$ is consequently placed under a system of public accountability;

- $\quad$ involves the basic idea of investment and returns and services. ${ }^{4}$

Although it is important to determine the institutional boundaries of parastatals and other state-related enterprises, I choose to emphasize in this study the similarity of the functions carried out by the Colombian and Ivoirian parastatals in their respective coffee sectors, regardless of the specific institutional differences existing between them.

These two organizations share the following key responsibilities with regard to the Colombian and Ivoirian coffee sectors: (1) the setting of domestic producer prices and revenue extraction; (2) the marketing of the national coffee crops; (3) quality control for annual crops; (4) the increased productivity of coffee farms; and (5) as a result of the previous duties, the creation of a link between the state and producers of all sizes. It is therefore on the basis of these shared responsibilities that I compare these two parastatal organizations.

The presence of these parastatals in the Colombian and Ivoirian coffee regions had different consequences for the two coffee sectors and national economies. FEDECAFE

${ }^{4}$ Joel Krieger (ed.), The Oxford Companion to the Politics of the World (New York, NY: Oxford University Press, 1993), p. 683. 
and the Caisse generated revenues for the state on very different scales. Both agencies taxed the sales of coffee berries and made a profit from the hard work of the mostly small producers. However, the leaders of these two institutions used their revenues for contrasting purposes. FEDECAFE managers reinvested the majority of the income in social services for Colombian coffee producers whereas executives of the Caisse diverted money from the coffee sector for political patronage and other areas of the economy.

Although national economic development is not the primary focus of this dissertation, the functions and actions of the parastatal agencies before and after 1989 have influenced the course of national economic development in both Colombia and Côte d'Ivoire.

As mentioned previously, there are few scholarly studies which deal specifically with the theoretical implications of parastatal agencies. Most of the relevant works discuss these agencies simply as part of the state or an extension of the state. While it is necessary to place these organizations within the context of the state and its realm, it is also important to go a step further in the analysis and observe what position these entities occupy vis-a-vis specific sectors of the economy and society. In addition, this dissertation will obviously explore the impact of international variables and changes on these parastatal entities.

Parastatals were generally established by the state for a distinct purpose. In most instances, they were created in the agricultural sector to help the state manage the production and distribution of export crops and/or food crops. Parastatal organizations in 
the agricultural sector exist in the Western world and in the "developing" world. ${ }^{5}$ In the latter, the establishment of these quasi-state agencies was theoretically to facilitate national economic development by providing the state with much-needed revenues. Because the two organizations under study in this work are in the developing world, it is on that portion of the relevant scholarly literature that this chapter will focus. In addition, I will discuss in this chapter why I believe that the Federación Nacional de Cafeteros de Colombia is a parastatal agency and not an association. I will also briefly summarize the literature on African marketing boards.

\section{State-Society Relations and Parastatals in the Developing World}

A discussion of the theoretical writings about parastatal organizations places us at the center of a number of classic questions within the academic community with regard to development theory. What is and/or should be the role of agriculture in the process of development? What is and/or should be the role of the state in development? I do not intend to review here all the arguments on either side of these important debates; I only wish to draw out some key points in order to meaningfully position the parastatal agencies and their role in the development literature.

Historically, it is hard to contest the role of agriculture in the development of Western societies. Agriculture allowed for the beginning of industrialization and economic development in Britain by providing a steady supply of food and raw materials,

${ }^{5}$ Marketing boards are discussed in various parts of the world in: Sidney Hoos (ed.), Agricultural Marketing Boards - An International Perspective (Cambridge, MA: Ballinger Publishing Company, 1979). 
the release of factors of production and the creation of the market. ${ }^{6}$ This pattern repeated itself in a variety of other European countries as they industrialized. Most scholars do agree generally on the key role of agriculture in the first "stages" of development.

Scholars disagree much more on how agriculture should influence the process of development over time. Is it, in fact, the transformation of agriculture that brings about the impetus for industrialization or are there other ways in which agriculture can support national development? In particular, in post World War II Latin America, discussions focused on export-promotion strategies versus import-substitution schemes. Export-led growth "is to set forces into motion that will expand the excess supply of exportable goods, thereby leading to a rapid expansion of output, employment, and earnings in the export sector." 7 The boom in the export sector is to carry over into other areas of the economy. In import-substitution approaches, the focus was not on exporting as much as possible but rather on creating industrial enterprises to replace imported manufactured goods within the developing country's boundaries.

Western scholars overall clearly prefer export-promotion strategies for Third World countries, even though these do present some problems. ${ }^{8}$ Streeten and Elson, for

\footnotetext{
${ }^{6}$ Bruce F. Johnston and Peter Kilby, Agriculture and Structural Transformation: Economic Strategies in Late-Developing Countries (New York, NY: Oxford University Press, 1975), p. 187.

${ }^{7}$ James P. Houck, "Observations on Export-Led Growth as a Development Strategy," in C. Peter Timmer (ed.), Agriculture and The State: Growth, Employment, and Poverty in Developing Countries (Ithaca, NY: Cornell University Press, 1991), p. 116.

${ }^{8}$ Robert Gilpin, The Political Economy of International Relations ( Princeton, NJ: Princeton University Press, 1987), p. 267.
} 
example, question specifically national coffee policies and their impact on development. ${ }^{9}$

They argue that coffee-producing nations may in fact want to limit their coffee production and exports to promote diversification and development. The primary issue, at the very center of this dissertation, remains the prices paid to the producing nations and producers for the commodities they export.

The role of the state in economic development is much more controversial. In Britain, the state was only involved in so far as it provided a liberal structure for development to occur; it let private capital be the engine of industrialization. For Polanyi, the role of the British state was central. The liberal framework it laid out originally and the labor and social protection laws added later (when necessary) allowed for real and significant industrial development to take place. ${ }^{10}$

In other European countries and in other parts of the world since then, it is fair to say that the state has had a more active role to play. By this I mean that the state has been a key participant in economic development; it did more than providing the conditions for development. For Gerschenkron, there is a definite relationship between industrialization and the state. ${ }^{11}$ The later a country industrialized, the more important the state's role. In particular, the state would be a significant source of capital for those participating in

${ }^{9}$ Paul Streeten and Diane Elson, Diversification and Development: The Case of Coffee (New York, NY: Praeger Publishers, 1971).

${ }^{10}$ Karl Polanyi, The Great Transformation: The Political and Economic Origins of Our Time (Boston, MA: Beacon Press, 1957).

${ }^{11}$ Alexander Gerschenkron, Economic Backwardness in Historical Perspective: A Book of Essays (Cambridge, MA: The Belknap Press of Harvard University Press, 1962). 
industrialization in "extremely backward areas." ${ }^{12}$ Gerschenkron foresaw that this trend would continue beyond the European cases that he studied.

The general consensus among academics and development practitioners in the early post-World War II phase was that the state had a critical role to play in the development of Third World countries. Timmer lays out in general terms the uncontested areas of government intervention in agriculture, according to scholars: agricultural research, agricultural extension, irrigation investments, and a minimal marketing infrastructure. ${ }^{13}$ A consensus emerged that government action in these areas was desirable and beneficial to national development. Agricultural research would allow the sector to be more efficient and productive; agricultural extension provides the necessary technical knowledge to producers to ameliorate their production and yield; and a minimal marketing infrastructure assists the growers in the sometimes complex process of exporting their crops. In other realms, however, there was little agreement on the necessity for state action. Disputed government options revolved around land tenure reforms, the creation of farmer organizations, the role of marketing boards, and government price interventions. Scholars studying agricultural issues position themselves vis-a-vis these different policy choices. Overall, until the mid-1980's, the state was considered a positive force in the process of agricultural and national development.

${ }^{12}$ Gerschenkron, p. 355 .

${ }^{13}$ C. Peter Timmer, "The Role of The State in Agricultural Development," in C. Peter Timmer (ed.) Agriculture And The State: Growth, Employment, and Poverty in Developing Countries (Ithaca, NY: Cornell University Press, 1991), pp. 1-28. 
It is in large part because of this prevailing acceptance of the state's role that the types of parastatals we are discussing in this work even came into existence. Farrington and Bebbington write: "in the agricultural sector, the effect of this state-centered strategy was to litter the institutional landscape with parastatal marketing companies, agrarian banks, land reform agencies, public institutions for agricultural research and extension, irrigation agencies, rural development programs and many more." ${ }^{14}$ If the state was to be very involved in the industrialization process and if agriculture was to be the viable base for an economic transition to take place, then it made sense for the state to expand its reach into the agricultural sector and ensure the production and profits that would enable the national economy to move forward.

Crawford Young uses the concept of the "integral state" to explain the creation of parastatal agencies in Africa. ${ }^{15}$ He sees this type of state as seeking total hegemony over society, enabling it to pursue its goals freely and to reward the ruling class for its support. For Young,

The policy implications of the integral state were far-reaching. The regulatory infrastructure of the colonial state was extended and deepened to include agricultural marketing monopolies, obligatory state cooperatives, administered prices in key sectors, and licensing of many economic activitities and external trade. The impetus to extended control inherent in the integral state drove the

${ }^{14}$ John Farrington and Anthony Bebbington, Reluctant Partners? Non-Governmental Organizations, The State and Sustainable Agricultural Development (New York, NY: Routledge, 1993), p. 5.

${ }^{15}$ Crawford Young, "In Search of Civil Society," in Civil Society and The State in Africa edited by John W. Harbeson, Donald Rothchild, and Naomi Chazan (Boulder, CO: Lynne Rienner Publishers, 1994), p. 39. 
parastatalization of the economy, even in states commonly considered of capitalist orientation (Côte D'Ivoire, Nigeria). ${ }^{16}$

In many African countries, agricultural parastatals were put in place prior to independence to control crop production and sales and extract revenue from the colony. The newly independent African states thus did not always create a new institution; they often took over one that was already functioning.

Alongside Young's explanation for the creation of parastatals in Africa, Merilee Grindle comments on the growth of the Latin American state's apparatus. She writes:

the Latin American state in the period between 1940 and 1980 introduced conditions that made capitalist expansion feasible and it assumed an ongoing role of intervention, resource allocation, and conflict resolution. In this role, it acquired an extensive administrative and political infrastructure in the countryside and promulgated a generous body of legislation that gave it the right to appropriate land and water resources to intervene widely in markets for land, labor and capital. The state was thus able to increase its power vis-a-vis the specific social classes or alliances and individual agencies acquired control over policy areas that they then used to build their own political and bureaucratic bases. ${ }^{17}$

What this organization does actually depends in large part on the relationship between the state and the society involved. How involved was society in the creation of the parastatal discussed? What segments of society were involved in the creation and continuation of the work of the parastatals? These questions lead us to the key theoretical framework for the discussion of these parastatals, in my opinion, the state-society literature. Some of the

${ }^{16}$ Young, p. 41.

${ }^{17}$ Merilee Grindle, State and Countryside: Development Policy and Agrarian Politics in Latin America (Baltimore, MD: The Johns Hopkins University Press, 1986), p. 4. 
questions asked include: how do we define the state? What is society? What are the relations between these two entities?

The state is defined by scholars who use the concept in two distinct manners. For many theorists framing issues in state-society terms, the state is a passive entity, basically a bureaucratic structure. Migdal, for example, defines the state as "an organization composed of numerous agencies led and coordinated by the state's leadership (executive authority) that has the ability or authority to make and implement binding rules for all the people. ${ }^{18}$ For other scholars, such as Skocpol, the state is possibly just another actor in the political arena, with specific goals and agendas, alongside all the other agents, such as civic organizations, political parties, and unions. ${ }^{19}$ I view the state as both a bureaucratic structure responding to and representing the various interests in the country, as well as an autonomous, active entity with its own distinct goals.

Fred Halliday notes the distinct uses of the term "state" in the discipline of International Relations. The "state" is rarely defined by traditional theorists as it is assumed that we all know what it is. In IR, the state refers to the "national-territorial totality" and encompasses the defined territory delimited on maps, and the "government, people, and society" of a country. ${ }^{20}$ Obviously this definition is substantially different from

${ }^{18}$ Joel Migdal, Strong Societies and Weak States: State-Society Relations and State Capabilities in the Third World (Princeton, NJ: Princeton University Press, 1988), p. 19.

${ }^{19}$ Theda Skocpol, "Bringing The State Back In: Strategies of Analysis in Current Research," in Peter B. Evans, Dietrich Rueschmeyer and Theda Skocpol (eds.), Bringing The State Back In (New York, NY: Cambridge University Press, 1985), pp. 3-43.

${ }^{20}$ Fred Halliday, "State and Society in International Relations" in Michael Banks and Martin Shaw (eds.) State and Society in International Relations (New York, NY: St. 
the one used in this dissertation. This reminds us, however, that the state we are studying in this work is not just an entity which functions in the domestic arena vis-a-vis all societal interests; it also operates in the international sphere, representing the country, negotiating international agreements and in the case of developing countries, seeking financial assistance from international organizations. This places additional pressure on the state, which in some instances is already struggling or weak.

The Latin American and African regional literatures have different things to say about the state as defined in this study. The various definitions of, and perspectives on, the state in the two regions under discussion originate in the differing historical trajectories of the continents. As a result, the vocabulary used varies even though, in many ways, the issues facing all developing countries are similar.

Discussions of the Latin American state in general are influenced by the writings of Latin American dependency theorists in the 1970's, who place the Latin American region and states on the periphery of the world capitalist economy. Among others, Faletto describes the constraints and opportunities faced by the Latin American state. ${ }^{21}$ The peripheral status of the region gives each statal entity in the Western hemisphere an even more important role in the pursuit of development. For him, each state directs "the flow and volume as well as the orientation of economic activity." ${ }^{122}$ Faletto views the state as

Martin's Press, 1994), pp. 191-209, p. 194.

${ }^{21}$ Enzo Faletto, "The Specificity of The Latin American State," CEPAL Review, 38 (1989), pp. 69-87.

${ }^{22}$ Faletto, p. 70. 
setting up and maintaining the institutional structure for the operation of capitalism. The state "organizes accumulation administratively" by putting into place a number of mechanisms to control foreign trade, transfer revenues from one sector to another and regulate exchange rates. ${ }^{23}$

Faletto does not mention parastatals, per se, but he writes about state enterprises and their relations with the state. He writes that, "state enterprises in Latin America have often expanded to the point of having their own accumulation base. That means more economic power for the state and consequently for the bureaucracy which in extreme situations began to manage the public sector in its own self-interest." ${ }^{24}$ For Faletto, a modern state working within a traditional society creates contradictions and problems. The state has to be ready to deal with the social conflicts resulting from the structural changes it puts forth; it also needs to resolve its internal discords. On the whole, Faletto does view the Latin American state as a weak entity despite its important role in national political economies. ${ }^{25}$

I agree with Faletto that the financial, monetary and physical structure created by the state has a significant impact on national economic activity. The state, however, does

${ }^{23}$ Faletto, p. 70.

${ }^{24}$ Faletto, p. 76.

${ }^{25}$ Faletto discusses at length the role of transnational capital in Latin America and the impact its presence has on the state. This topic will not be discussed directly in this dissertation as coffee production is almost exclusively a Colombian activity. All the coffee farmers are Colombian, the land is Colombian and the investment in the coffee growing is Colombian as well. Transnational capital only affects coffee markets further up along the commodity chain. 
not only provide structure to the economy; it is also an active participant in economic development.

The literature on African states reveals similar theoretical issues for its students.

Martin Doornbos describes quite well the complex position of the African state.

According to him, it has

a particular configuration, including (i) its post-colonial status, with all the implications this has for the evolution of civil society, (ii) its a priori problematic relationship as regards its territorial jurisdiction, (iii) its heavy involvement in a restricted resource base (usually primarily agricultural), (iv) its still relatively undifferentiated yet ethnically heterogeneous social infrastructure, ( $v$ ) its salient processes of centralisation and consolidation of power by new ruling classes, and (vi) its pervasive external context and dependency. ${ }^{26}$

The African state thus faces a number of difficult issues. Its recent colonial history continues to influence its path. The lack of correlation between ethnic groups and national boundaries splits ethnicities into different countries and adds to the tensions existing within societies and among artificially-created African states. Most African countries depend primarily on their agriculture for income and foreign exchange earnings. The African state, although fairly weak, is generally "taken over" by the new ruling classes.

As it became clear in the 1980 's that the African state was not meeting its challenges, some began to view the state as an obstacle to development. In many instances, however, the expectations placed on the state with regard to nation-building and

${ }^{26}$ Martin Doornbos, "The African State in Academic Debate: Retrospect and Prospect," The Journal of Modern African Studies, 28, 2 (1990), pp. 179-198, p. 180. 
development were just too high. Even though the African state in general is weak, it is still the most "prominent landmark on the African institutional landscape."27

The other key entity in the developing world is "society". The most basic definition of the term indicates that "a society is a group of people who are dependent on one another for survival and/or well-being and who share a particular way of life or culture." 28 The society we are studying in this work is obviously a national society, which is made up of a variety of different ethnic, religious, territorial, economic, and professional parts working in many distinct directions. ${ }^{29}$ Huntington formulates the idea that more complex societies are more dependent on the functioning of their political institutions. ${ }^{30}$ Marxists see class as an essential determinant of society, while statists see the state as formative of social identities and claims. The distinction between society and civil society is an important one. For Migdal, associations in civil society differ from other groups in society because they address the state primarily. ${ }^{31}$ Other groups in society address other social entities and concerns, not the state first and foremost.

\footnotetext{
${ }^{27}$ Michael Bratton, Beyond The State: Civil Society and Associational Life in Africa," World Politics , p. 410.

${ }^{28}$ Serena Nanda, Cultural Anthropology Fourth Edition (Belmont, CA: Wadsworth Publishing Company, 1991), p. 6.

${ }^{29}$ Joel S, Migdal, Atul Kohli, and Vivienne Shue, State Power and Social Forces: Domination and Transformation in the Third World (New York: Cambridge University Press, 1994), p. 18.

${ }^{30}$ Samuel Huntington, Political Order in Changing Societies (New Haven, CT: Yale University Press, 1968), p. 9.

${ }^{31}$ Migdal, State Power and Social Forces, p. 29
} 
Regarding the problems of state-society relations, one sees basically three perspectives. The first outlook on the relationship between state and society is that the state is the most important focus for studying development and assessing the situation in any country. The second position puts forth society as the key to evaluating political and economic conditions. The third perspective, and the one that will be followed in this study, posits that it is the relationship between state and society which needs to be emphasized for a clearer picture of the dynamics at work. I am a proponent of Migdal's state-in-society approach. The structure and operations of the state are, in part, the result of the society at large within which the state functions. The two structures interact in ways that are sometimes difficult to identify.

The segment of society on which this study will focus is farmers and specifically coffee producers in the two countries under consideration. The relations between peasants and the state represent an important section of state-society relations in Latin America and Africa. Michael Bratton creates an interesting typology for the patterns of interaction between the two parties in African agriculture. ${ }^{32}$ I believe that his classification is useful not only for a description of state-peasant relations in Africa but also in Latin America. He begins by defining engagement and disengagement on the part of both state and society:

State-sponsored engagement refers to efforts by state elites authoritatively to regulate social behavior. This type of political initiative includes, inter

${ }^{32}$ Michael Bratton, "Peasant-State Relations in Postcolonial Africa: Patterns of Engagement and Disengagement," in Joel S. Migdal, Atul Kohli and Vivienne Shue (eds.), State Power and Social Forces: Domination and Transformation in The Third World (NewYork, NY: Cambridge University Press, 1994), pp. 231-254. 
alia, pacification of national territory, promulgation of legal codes, and efforts to plan centrally economic production, distribution, and exchange. State-sponsored disengagement refers to retrenchment by state elites who encounter limits to the reach of public authority. It is manifest, for example, in concessions of liberated areas to rebels, in devolution of legal jurisdictions to traditional or religious authorities and in reforms to liberalize and privatize economic activities.

Society-sponsored disengagement refers to actions by ordinary citizens to withdraw from the realm of state authority or otherwise to evade compliance with official directives. Examples include refugee flight, popular disregard for civil and criminal laws, and black-marketeering. Society-sponsored engagement refers to collective action by citizens to influence the allocation of public resources or gain control of state power. Examples include voting, lobbying, patronage claims, political protests, and armed resistance. ${ }^{33}$

According to Bratton, the options of state and society with regard to engagement and disengagement are in large part determined by the autonomy and the capacity of the actors involved. These concepts have mostly been defined and used by political theorists in reference to the state. For Skocpol, "states conceived as organizations claiming control over territories and people may formulate and pursue goals that are not simply reflective of the demands or interests of social groups, classes or society. This is what is usually meant by state autonomy."134 She views state capacity as being determined by the following: "sovereign integrity, stable administrative-military control of territory, loyal and skilled officials, and plentiful financial resources." ${ }^{135}$ For Bratton, autonomy is the ability of the parties involved to make political decisions without interference from other actors; capacity is the ability to put policies into effect. Bratton uses these concepts to analyze

\footnotetext{
${ }^{33}$ Bratton, p. 235.

${ }^{34}$ Skocpol, p. 9.

${ }^{35}$ Skocpol, p. 16.
} 
both the state and society. He believes that almost all organizations in Africa, whether they pertain to the state or to society, have relative autonomy but very limited capacity. ${ }^{36}$

From there, Bratton moves on to describe for us the different scenarios in statepeasantry relations with regard to engagement versus disengagement. His first scenario is one in which both the state and society are engaging each other. In his opinion, this is in many instances the result of the national independence struggle fought by both state leaders and peasants in search of the country's freedom. The peasants, just like other social groups in these countries at this historical juncture, were prepared to work with the new state in the establishment of national institutions. For Bratton, this willingness to engage on both sides resulted in "agricultural production schemes." ${ }^{137}$ These arrangements would be based on a peasant form of production even though they were instituted by a government ministry or a new parastatal organization. This arrangement would allow the state to explore technologically innovative means of production and distribution and work towards increasing the national production of much-needed export crops. The peasants were interested in the economic resources which the production scheme would give them, such as cheap credit, access to free plants and fertilizers, agricultural training, etc. For Bratton, the comparatively significant resources available to the state and the lack of means on the part of the peasantry eventually lead countries in this situation to the dominance of the state and the subordination of the peasants involved. How long the

\footnotetext{
${ }^{36}$ Bratton, p. 239.

${ }^{37}$ Bratton, p. 240.
} 
latter are willing to remain in the "scheme" depends on their perception of the benefits and/or costs to them.

The second scenario put forth by Michael Bratton is one in which the state engages and society disengages; it results in the creation of "marketing cooperatives." ${ }^{38}$ This represents a looser form of state-society relations and is, according to Bratton, the most common political initiative in the African countryside. These cooperatives enabled the state to be involved in the production of export crops and theoretically allowed the peasants to decide whether or not they wished to participate in the organization and its decision-making. In many instances, however, the state ended up consolidating these loose marketing cooperatives and making them both part of the national regulatory chain and an annex for the state marketing boards. In this process, Bratton writes that the peasants lost their share of participation in the process. ${ }^{39}$ In his explanation of this scheme, Bratton mentions the cooperative movement in Côte D'Ivoire.

Bratton's third scenario is one in which both state and society disengage in the agricultural realm. In this scheme, peasants look for non-state alternatives for their economic welfare as they do not trust or utilize the state's mechanisms; they create "trading networks" ${ }^{40}$ beyond the state's control through which they can sell or exchange their crops for consumer goods. These trading networks take on a variety of forms, from village markets to international crop-smuggling rings. This scenario has a tremendous

\footnotetext{
${ }^{38}$ Bratton, p. 243.

${ }^{39}$ Bratton, pp. 243-245.

${ }^{40}$ Bratton, p. 245.
} 
impact on the state itself which begins to disintegrate. Bratton concludes this section of

his discussion with the following comment:

The disengagement of the state has been formalized in those African countries where the government has applied a package of structural adjustment reforms to the economy. These reforms include some or all of the following measures: removal of administrative controls in favor of market prices, dissolution of loss-making public enterprises, reductions in public sector employment, and opportunities for private traders to enter agricultural markets. ${ }^{41}$

Bratton's last possible scenario for peasant-state relations is one in which the state disengages and society engages. An absent (and I would add weak) state in the social landscape leaves open space for a variety of activities, some violent and some peaceful. Bratton focuses on the most promising prospect, namely a situation in which peasants take advantage of the available social and political space by creating "farmer associations." ${ }^{42}$ They can be a way for the peasants to engage the state. Bratton describes the conditions under which these formal and voluntary organizations come about:

Several preconditions seem to be necessary: an ideology of reciprocity and a tradition of collective action in the agricultural sector; a strong set of shared economic interests, often embracing farmers engaged in the production of a particular commodity; the availability of models of economic interest association, for example, the large scale commercial farmer unions in former settler colonies; and a favorable economic environment in which agricultural surpluses can be disposed of at a profit beyond the household. ${ }^{43}$

\footnotetext{
${ }^{41}$ Bratton, p. 248.

${ }^{42}$ Bratton, p. 248.

${ }^{43}$ Bratton, p. 248.
} 
Bratton cites several farmer associations that have come into existence as a result of these preconditions: regional peasant associations in Senegal and Burkina Faso, the Zimbabwe Farmers Union, and the Kenya National Farmers Union. ${ }^{44}$

He believes that these associations are formed under circumstances where it is difficult for producers to make a go of it on their own. Larger scale farmers in many instances take the lead and create a regional and national structure for the organization. In general these groups seek to assist farmers with "credit, insurance, information, input, transport, and processing services. ${ }^{145}$

Bratton discusses the implications of these farmer associations for state-society relations. He argues that developments following the creation of the association will depend on the autonomy and capacity of the entity under discussion. I believe that his analysis of farmer associations is in fact quite useful in understanding historical developments in Colombia.

Throughout this dissertation, the analysis of state-society relations and more specifically the parastatals in the coffee sectors of Colombia and Côte D'Ivoire will be framed in part by Bratton's typology. Bratton has created these categories to enhance our ability to analyze relations between the state and rural society. It is clear, however, that the scenarios formulated in his typology are not permanent ones. States and societies may engage and disengage at various points in time, thus changing the relations between them and the applicable scenario for the situation. The possible patterns are thus quite fluid and

\footnotetext{
${ }^{44}$ Bratton, p. 249.

${ }^{45}$ Bratton, p. 249.
} 
understanding them will assist us in our comprehension of state-societal changes following the coffee crisis of 1989. In this study, I am examining in part how external shocks affect the patterns laid out by Bratton.

In addition to using Bratton's typology, this dissertation will emphasize, wherever possible, the distinction between the situations and actions of large farmers versus those of small ones. The larger farmers have more input into the policy-making of the state than the small ones do, in both Latin America and Africa. ${ }^{46}$ On both continents, however, small coffee-producing farmers are much more numerous.

\section{Adding the International Variable}

To The Study of Domestic State-Society Relations and Parastatals

All of this discussion of state-society relations needs to be placed within the context of the international market. The state can be discussed both from the perspective of state-society relations and from the angle of state-market relations. ${ }^{47}$ Bates writes about the peasant and the state in relation to the market in Africa specifically but his assessment is also valid of the general situation in Latin America.

The market is the setting for the struggle between the peasant and the state. Through intervention in the market, the state seeks to manipulate the behavior of rural producers. It seeks to levy resources from the countryside: money, people, food, and raw materials. It also seek to set

${ }^{46}$ Robert Bates, Markets and States in Tropical Africa: The Political Basis of Agricultural Policies (Berkeley, CA: University of California Press, 1981), p. 86.

${ }^{47}$ Manuel Antonio Garretón, "New State-Society Relations in Latin America" in Colin Bradford (ed.), Redefining The State in Latin America (Paris, France: OECD, 1994), pp. 239-250, p. 244. 
terms for the supply of these resources, terms that restructure the patterns of advantage both within the countryside and between the countryside and urban industrial areas. For their part, the rural producers use the market as a means of defense against the state. By reallocating resources among economic alternatives, they seek to defend themselves against the depredations imposed upon them by many aspects of public policy. The result is a struggle in the marketplace between the peasants and the state. ${ }^{48}$

Although the marketplace mentioned by Bates could be domestic, his argument also holds for the international marketplace. It is a place of contention between the peasants and the state.

The market to be considered in this dissertation is obviously the international coffee market as discussed at length in the previous chapter. Few academic scholars have discussed the impact of international markets and crises on state-society relations specifically. Those who have include Peter Katzenstein, Peter Gourevitch, and Merilee Grindle. It is important to review some of their ideas and arguments as they relate to state-society relations, even though none of them focused directly on the agricultural sector.

In his work on Austria and Switzerland, Katzenstein compares the impact of the international markets on the open political economies of Austria and Switzerland. ${ }^{49} \mathrm{He}$ studies the state from two theoretical perspectives: as an actor and as part of a policy network, thus enriching his analysis. He argues that the position of both countries in the

${ }^{48}$ Robert Bates, Markets and States in Tropical Africa, p. 6.

${ }^{49}$ Peter Katzenstein, "Small Nations in an Open International Economy: The Converging Balance of State and Society in Switzerland and Austria," in Peter Evans, Dietrich Rueschmeyer \& Theda Skocpol (eds.) Bringing The State Back In (New York, NY: Cambridge University Press, 1985), pp. 227-251. 
world economy has led both countries to create a web of very closely intertwined statesociety relations but in very different ways. The strong state in Austria has crafted very close relations with its labor unions while the weak Swiss state focused on its relationship with its business community. The two countries need these close connections with different societal communities in order to counterbalance the unpredictablity of the international markets. In each instance, then, the state is working very closely with an important segment of society to face the ups and downs of the world economy on which they depend.

Gourevitch describes and analyzes the responses of five Western countries to three international crises. ${ }^{50}$ He studies the way in which these states and the societies which surrounded them reacted at these historical junctures. His conclusions are quite relevant to this dissertation. He writes:

International economic crises are to countries what reagents are to compounds in chemistry: they provoke changes that reveal the connections between particularities and the general: if the comparativist can find countries subject to the same stresses, it then becomes possible to see how countries differ or converge and thereby to learn something about cause and effect. ${ }^{51}$

This is in part what I intend to do in this dissertation.

For Gourevitch, it is important to explore the connection between crises and countries. ${ }^{52}$ Crises transform nations but also reveal some of the dynamics at work within

${ }^{50}$ Peter Gourevitch, Politics in Hard Times: Comparative Responses to International Economic Crises (Ithaca, NY: Cornell University, 1986).

${ }^{51}$ Gourevitch, p. 221.

${ }^{52}$ Gourevitch, p. 221. 
them. Crises and nations evolve with time; each country responds to each crisis differently.

From his comparison of the United States, the United Kingdom, France, Germany, and Sweden facing three key crises in the nineteenth and twentieth centuries, he draws some implications and generalizations for the changing rapport among different segments of society and evolving relations between state and society. He describes, for instance, the division of farmers into two groups in late $19^{\text {th }}$ century Europe. They would no longer stand together as one group with regard to economic policy. The producers of commodity crops for export began supporting a protectionist alliance that wanted higher prices while the growers of food stuffs for the urban markets were in favor of free trade.

For Gourevitch, state actions can be understood in large part by observing the relationship between the state and the societal actors around it. The state structures in place during a crisis have a significant effect on the resolution of the crisis and its participants. ${ }^{53}$ Gourevitch also views the specific structures of the state which serve as a link to society as more important during crises. ${ }^{54}$ This explains the key role of the coffee parastatal in the coffee crises, as well as the creation of new associations representing coffee producers. In addition, he claims that the expansion of the state apparatus in each country has not been a linear one and that each state goes through periods of growth and periods of contraction.

${ }^{53}$ Gourevitch, p. 231.

${ }^{54}$ Gourevitch, p. 229. 
Of particular relevance to this study is Gourevitch's analysis of the relationship betwen the international system and national politics. ${ }^{55}$ Changes in the international political economy put pressure on specific actors within a country. The affected social groups in the country under study then seek policy changes from their state. (This is why nations cannot be considered as one, unitary entity). Gourevitch also acknowledges that smaller nations have less control over the environment that affects them. They are not free in their response to a crisis as "the international system rewards some behaviors, punishes others ..."56 Countries do make their own policy choices though, sometimes against the preferences of the international system.

Merilee Grindle's comparative study is in focus the closest to this dissertation. ${ }^{57}$ She examines how crises and in particular international ones affect state capabilities in Latin America and Africa in general and Mexico and Kenya in particular. She makes and supports the following four points regarding Latin American and African states facing crises. First, the institutional capacity of the state to set boundaries for economic and political interactions will be diminished. In practical terms, this means that the state will be less able to "regulate property rights, enforce contracts, maintain law and order, and control official acts of corruption and abuses of power." $\$ 8$

${ }^{55}$ Gourevitch, pp. 234-238.

${ }^{56}$ Gourevitch, p. 235.

${ }^{57}$ Merilee Grindle, Challenging The State: Crisis and Innovation in Latin America and Africa (New York, NY: Cambridge University Press, 1996).

${ }^{58}$ Grindle, p. 31. 
Second, the technical ability of government to direct macroeconomic policies will be reinforced. This was due to the fact that a growing number of Latin American and African elites pursued degrees in macroeconomic policy in the United States and Europe and returned to their native countries to work in government positions.

Third, the bureaucratic capability of the state to pursue its usual duties will be reduced because of severe budgetary constraints. For Grindle, "it is a critical capacity, however, because it affects the ability of private economic agents to achieve their goals, the availability of a well-trained and healthy workforce, and the satisfaction of basic societal needs." ${ }^{99}$ Finally, the capacity to arbitrate conflict and oversee requests for political participation will be decreased as the state leaders feel threatened and are unable to provide the demanded goods and services.

Grindle believes, however, that the crises faced by developing countries will not only bring about a challenge to the capacities of the state. She believes that these situations create new spaces for society to speak out and influence state actions. She writes:

Economic and political crises had a destabilizing effect on existing stateeconomy and state-society throughout Latin America and Africa, and in many ways, the capacity of states to encourage economic development and maintain social stability was severely undermined. Nevertheless, these crises opened up increased space between state and economy for deliberate efforts to craft new relationships between state and economy and to redefine relationships of power and accountability with society. ${ }^{60}$

\footnotetext{
${ }^{59}$ Grindle, p. 37.

${ }^{60}$ Grindle, p. 4
} 
Grindle thus views these crises in part as opportunities to forge new relationships within the society and between the state and the other civic actors involved.

In her conclusion, Grindle argues:

politics is also central to the effective pursuit of development. Engendering a shared vision of the future, building coalitions of interests, mobilizing electoral support, attracting talented people to public service, encouraging responsiveness to public needs, and mediating conflict in the interest of political stability - these are all tasks that are essential to promoting economic and political development and they are ones traditionally assumed by political leaders and institutions. ${ }^{61}$

Grindle's analysis helps us understand the different responsibilities of the state in the developing world and how they are affected by economic crises. As she points out, the changing role of the state has a direct impact on society, its role and its actions.

In the late liberal world, international economic crises are endemic. It is thus particularly important to study their impact on state, society and the relations between them.

\section{Parastatals and Change}

Having discussed some of the ideas put forth by other authors regarding the effect of critical international situations, it is time to address two key questions for this theoretical chapter. Where did the parastatal come from? What happens to a parastatal after an economic and political crisis which affects its realm of intervention? In this study, we are particularly concerned with the path of the Colombian and Ivorian coffee parastatals following the adoption of neoliberal economic principles by the international

\footnotetext{
${ }^{61}$ Grindle, p. 193.
} 
financial institutions in Washington, DC, and the collapse of the International Coffee Agreement in 1989.

Earlier in this chapter, I stated that parastatal agencies are generally, and most often, created by the state for a given purpose. However, in a few countries, the quasistate entities were formed with the support of the state but originated within a key segment of society. We will see in the next section the role that coffee elites played in the formulation of FEDECAFE.

I will argue in this dissertation that the involvement of society in the formation of the coffee parastatal will affect the outcome for this parastatal following the collapse of the coffee agreement. The more society is associated with the founding of the quasi-statal agency, the more the latter is likely to survive the crisis. Survival alone, however, does not preclude the transformation of the organization. It is because of the potentially key role of society in the creation and maintenance of the parastatal that I place my analysis of the two coffee parastatals within the state-society framework.

I envision three possible scenarios for the relationship of those organs with the states and societies in which they exist. My first possible scheme would involve the complete disappearance and/or elimination by the state of the parastatal in question. I see two different types of situations which could result in the dissolution of the parastatal. In the first set of circumstances, the parastatal was created for a limited defined purpose. As a result of a crisis or change of circumstances, the functions fulfilled by that parastatal are no longer relevant or necessary. The parastatal would then be simply eliminated by the state as it is no longer needed to fulfill a certain role. These words describe quite well the 
situation of the parastatal entities in several Central and Latin American coffee-producing countries: Brazil, El Salvador, Mexico and Nicaragua. ${ }^{62}$ A number of them set up coffee stabilization funds or parastatals to fulfill their country's requirements vis-a-vis the International Coffee Organization. When the International Coffee Agreement came to an end in 1989 , the states mentioned above simply and quickly did away with the state agencies. In these countries, coffee producers and elites had very little say in the creation of the organization.

The elimination of a parastatal could also take place under intense pressure from international institutions. This scenario could take place as a result of neoliberal reform packages that the developing state in crisis has to agree to in order to receive much needed financial assistance from the International Monetary Fund and the World Bank. This scenario would involve in my opinion a comparatively weak state (vis a vis the International Monetary Fund and the World Bank) in the midst of a severe economic and political situation. In this instance, it matters little whether the parastatal is in a key national economic sector or not. After eight years of resisting the international pressure for the elimination of the public Caisse de Stabilisation, Côte d'Ivoire finally succumbed and agreed in 1997 to the dissolution of the Caisse as a public entity in 1999. The involvement of society in the formation and dissolution of this quasi-state entity was limited, despite the difficult situation of the agricultural society and its expression of anger and frustration in streets around the country.

62 Takamosa Akiyama and Panos Varangis, "Perspectivas del mercado mundial del cafe," in Economia Cafetera: Crisis y Perspectivas (Bogotá, Colombia: Centro Editorial Javeriano, 1993), pp. 13-34, p. 25. 
My second scenario, probably the most unlikely one, entails circumstances under which the parastatal under attack remains in existence without any change to its structure, functioning or role. I see this scenario emerging in situations when the parastatal under discussion has an important part to play in one of the key sectors of the economy and when the state involved is strong enough to resist the potential demands of the international financial institutions and internal societal groups. I have no specific examples of this scenario.

The third scheme I can envision is one in which the parastatals under study remain in existence but modify their structure and function in the economy and in society. These parastatals would in my opinion have a key position in a significant sector of the national political economy. They will modify themselves or be modified by the state and society in response to the crisis at hand. This would either be in response to specific changes in the needs of the state and the economy or simply in an attempt by the organization to remain in existence. This is a familiar survival technique. Ernst Haas, for example, describes how international organizations transform themselves mainly in order to survive. ${ }^{63}$ The various ways in which they do this could apply to a domestic organization and include incremental growth and turbulent non-growth. For Haas,

one labeled incremental growth features the successive augmentation of an organization's programs as actors add new tasks to older ones without any change in the organization's decision-making dynamics or mode of choosing. The other, labeled turbulent nongrowth involves major changes

${ }^{63}$ Ernst Haas, When Knowledge is Power: Three Models of Change in International Organizations (Berkeley, CA: University of California Press, 1990). 
in organizational decision making; ends no longer cohere, internal consensus on both ends and means disintegrates. ${ }^{64}$

Do either of these types of growth apply to the parastatals under study, possibly only for a short time? Society would be a key determinant in the change of the parastatal as a result of its previous key involvement with the organization.

I believe that the third scenario is the one which is most applicable to Colombia over the entire time period under discussion. I will argue that in the Ivoirian case this scheme was valid until 1997. It took considerable external effort to convince the Ivoirian leaders to eliminate it as part of the state structure. After all, according to Blanford:

Once introduced, a board tends to be an institution of considerable permanence. Existing marketing structure becomes adapted to centralized control and to a large extent dependent on it. It is then potentially disruptive to make major changes in the system. It is worth noting that even though many economists have been highly critical of the operations of particular boards, most continue to survive intact. ${ }^{65}$

The analysis of the case studies in Chapters Three through Six will answer the various questions posed throughout this theoretical overview and will enable us to present a clear picture of the coffee parastatals under study, their role in coffee production and distribution, their position in state-society relations and their contribution to national economic development.

Prior to moving on to the actual discussion of the dissertation's cases, it is important to review a few lesser theoretical issues of direct relevance to this study. These

${ }^{64}$ Haas, p. 4.

${ }^{65}$ David Blanford, "West African Export Marketing Boards," in Sidney Hoos (ed.), Agricultural Marketing Boards: An International Perspective, p. 146. 
involve a presentation of my arguments regarding FEDECAFE's status vis-a-vis the Colombian state and society. It also involves a brief overview of the literature on the African marketing boards.

\section{FEDECAFE as a parastatal organization}

It is important at this stage to discuss why it is my position that the National Federation of Coffee Growers in Colombia (FEDECAFE) is a parastatal agency and not a civic association. This seems to be an issue throughout the literature on FEDECAFE, with scholars positioning themselves on one side or the other in the debate. Bennett Koffman's dissertation has played an important role in this debate since his whole study is, in his opinion, the analysis of an association and not a parastatal. ${ }^{66}$ While I appreciate the wealth of detailed information Koffman gives us on FEDECAFE's history, I believe that the story he tells is that of a parastatal and not an association.

Koffman defines "an associational group" as "a formal organization which has the specialized function of articulating the interests of its members to the political and

government structures of a political system." ${ }^{67}$ I do agree that FEDECAFE represents the interests of some of its larger members to the Colombian government. However, I consider that by designating FEDECAFE as an association, Koffman is putting aside the

${ }^{66}$ Bennett E. Koffman, The National Federation of Coffee-Growers of Colombia (Charlottesville, VA: University of Virginia, Dissertation in Political Science, 1969).

${ }^{67}$ Koffman uses the definition of association put forth by Gabriel Almond and G. Bingham Powell in their work Comparative Politics: A Developmental Approach (Boston, MA: Little, Brown and Company, 1966), p. 78. 
most conceptually challenging aspects of the Federation, namely its state-sponsored origins and history.

There are four reasons for my position. First, it is obvious that the state was involved in the maintenance of the organization from the very beginning. I believe that Bratton's discussion of farmer associations is quite helpful here. The large coffee producers in Colombia understood that it would be in their interest to create such an organization and they gave it the impetus it needed to get off the ground. However, the organization lacked the capacity to remain independent from the state, especially in the financial arena. Its leaders encouraged the very creation of the organization. Without the government's interest in coffee production and in the organization's potential, it would never have come about. Other similar types of agricultural organizations were created in Colombia in the first years of the 20th century but fell apart immediately because they were not strong enough on their own and did not have state support.

Second, just a few years after the creation of the organization, the Colombian government passed legislation giving itself a significant influence in the decision-making of the organization. A number of the members of the National Committee had to be Ministers from various government ministries and the Federation's activities would supervised most closely by the Ministry of Industry which would have veto power over the organization's activities and foreign representation.

What are the Federation's responsibilities? In the coffee-producing regions of Colombia, FEDECAFE has taken on a number of the state's own functions. It is in charge of overseeing the production, marketing and distribution of coffee in the Colombian 
countryside. In addition, however, it is also involved in the provision of numerous and impressive services to the coffee producers. The basic and technical education of the growers, their health, their electricity and water supplies, the construction of roads throughout the coffee region are some of the issues of concern to the Federation. These are services that are normally provided by the state. The Colombian state, however, has relied and continues to rely on FEDECAFE to put in place and maintain these services.

Escobar discusses the institutional framework of the Federation as one that looks like that of a state. She writes:

We can add an institutional framework that moulds itself onto the organization of the Federation with its National Committee, its Regional and Municipal Committees. This "institutionalism," however, goes beyond that because it is also conveyed in the financial, social and transport areas in such a way that the institutional network of the Federation does not limit itself to the problems of coffee production and export but delves into the social and economic life of the producers. It has constructed a bureaucracy of decision-making that has reached levels of efficiency and efficacy which in some instances are much higher than the state's. ${ }^{68}$

In addition to the state and bureaucratic functions the Federation has taken on, it also has international responsibilities. There are eight FEDECAFE offices around the world to represent the Federation and Colombian coffee interests. In addition, Federation delegates represent the Colombian state in all international coffee-related meetings and are given decision-making abilities at these meetings. According to Escobar, the only statal responsibilities the Federation does not have in the coffee region are of judicial and

${ }^{68}$ Maria Paulo Escobar Tello, FEDECAFE Y Estado: Historia, Coyuntura, y Transformacion de Una Relación Paraestatal (Bogotá, Colombia: Thesis, Universidad de los Andes, 1995), p. 16. 
military nature. ${ }^{69}$ FEDECAFE does not have its own courts or its own military or police force.

Finally, how are the activities of the entity under study financed? A tax is levied on the export of each sixty-pound bag of coffee. Starting in 1940, the proceeds of this tax have been placed in the Fondo Nacional del Cafe (FNC). The management of the funds in the FNC has been entrusted to the Federation of Coffee Growers by a legal and renewable contract to provide a broad range of services to the coffee-producing community. The Federation thus performs a number quasi-state functions in the coffee region with public funds. The combination of these four facts regarding the Coffee Federation lead me to argue that it is a parastatal organization and not an association.

\section{African marketing boards}

Commodity marketing boards are a common feature in the political and economic landscape of Africa. In most instances, as mentioned previously, they were established by British and French colonial authorities. The colonizers instituted these agencies during or after World War II as a way to either support the colonial administration or to extract revenues from the colonies to send back to the mainland. Since export crops were the main source of income for the African territories, it made sense that the British and French authorities would focus on them. Thus, the newly independent African governments did not create the marketing boards but rather simply took over and maintained the agencies.

${ }^{69}$ Escobar, p. 33. 
The most basic function of marketing boards throughout the African continent is to "purchase cash crops for export at administratively determined domestic prices, and then sell them at the prevailing world market prices. ${ }^{170}$ The manner in which this is done and the impact on the farmers varies from country to country. In a number of countries, other tasks relating to crop production have been added to the primary purpose of the board.

The African governments in general decided to perpetuate the existence of marketing boards because it was advantageous for them to do so. The benefits for the young states were numerous and they included financial, political, technical and social reasons.

Prior to discussing those reasons, I would like to distinguish between two types of crop marketing boards. Marketing boards in Africa have been set up to manage export crops and food crops. The boards in place for the marketing of food crops have not been as successful as those dealing with export crops because it is more difficult for the agencies to control the sales of food crops. ${ }^{71}$ It is quite easy for the farmers to sell food crops to sources other than the board; it is also possible, in some instances, for them to cross the border into another country and sell their produce there. Controlling the movement of export commodities is a bit easier and more interesting for African states. African states may see substantial financial benefits from their marketing boards. In general, the agencies are able to keep commodity prices for peasants lower than the

\footnotetext{
${ }^{70}$ Bates, Markets and States in Tropical Africa, p. 11.

${ }^{71}$ Bates, Markets and States in Tropical Africa, p. 40.
} 
world prices and are able to make a profit from the sales of export commodities abroad. It is assumed that small farmers are not able to organize politically to demand higher prices. ${ }^{72}$

This situation does not repeat itself across the entire continent. In a few countries, the national political and economic elites are involved in the production of export crops controlled by a marketing board. In these instances, the prices given to all producers of the crop in question will be good relative to world prices. We will see later in this dissertation that in Côte D'Ivoire, coffee was historically tied to the national elites and thus all coffee farmers benefited from reasonable prices until the elites moved out of coffee production during the 1970 's. At that point, coffee prices became less attractive for the small farmers.

Because, in general, these marketing institutions extracted so much capital and wealth, states looked for ways to officially or unofficially divert funds from these boards to other sectors of the economy. ${ }^{73}$ In some instances, the states took loans from the agencies and never reimbursed them. In other cases, the states just took the funds they needed out of the marketing board's resources. These marketing boards definitely provided African states with much needed financial resources. Bates writes: "because agriculture represents the principal economic activity in most of Africa and often generates the greatest volume of foreign exchange, the agencies that controlled the market for

${ }^{72}$ Jonathan Barker, Rural Communities Under Stress: Peasant Farmers and The State in Africa (New York, NY: Cambridge University Press, 1989), p. 101.

${ }^{73}$ Bates, Markets and States in Tropical Africa, p. 13. 
agricultural exports soon became the wealthiest and economically most significant single units in their respective economies. ${ }^{174}$

As a result of the economic position of these marketing boards, the latter became an important player in the institutional landscape created by the state. The directors of the marketing boards became significant leaders in the national economy and began to have a say in national politics.

It is also important to discuss the political and social benefits that the state sees in the existence of the marketing boards. These marketing boards, according to Barker, provided many opportunities for political patronage, a key to African politics. He believes that "licenses to buy, sell, or transport crops; jobs in marketing agencies and positions in cooperatives; loans: all these could be allocated in such a way as to build a following or cement a clientele. ${ }^{15}$

The position of the marketing boards vis-a-vis the peasants also enabled the state to reach out to the communities more easily. ${ }^{76}$ The marketing boards were the most visible state presence in the rural areas; they were the one entity that the farmers recognized and dealt with. African states began to use the marketing boards as a tool to extend out to the farming communities in new ways.

The relationship between the state and the peasants is not necessarily an antagonistic one. Although the state is definitely more "powerful" than the peasants, the

\footnotetext{
${ }^{74}$ Bates, Markets and States in Tropical Africa, p. 13.

${ }^{75}$ Barker, p. 112.

${ }^{76}$ Bates, Markets and States in Tropical Africa, p. 116.
} 
state needs the peasants to continue producing the export crops so that it can continue to extract resources. Peasants of course primarily seek reasonable prices for their crops.

In an attempt to use this new method of reaching the agricultural communities, the states began to use the marketing boards to improve crop production methods. ${ }^{77}$ In many instances, the states provided producers with basic technical assistance, using the marketing agencies to reach the producers, despite the fact that many times the result was not particularly good. To complement these efforts, the state also added on technical assistance as one of the functions of marketing boards. Extension agents began working with peasants on a variety of issues.

The African marketing board is therefore at the center of an entangled web involving key financial, political, social and technical issues. Many analysts view these organizations as "inherently and systematically harmful." young state's need for revenue and political control and its use of the marketing board to meet its needs.

This brief discussion of the literature on African marketing boards enables us to see how African states saw marketing boards as a key economic resource and a tool to reach out to the agricultural communities in a variety of ways. The functions carried out by the marketing boards are similar to those of the parastatals I described earlier. It is therefore possible to discuss marketing boards as parastatals.

\footnotetext{
${ }^{77}$ Barker, p. 114.

${ }^{78}$ Richard C. Crook, "Farmers and The State," in Douglas Rimmer (ed.), Rural Transformation in Tropical Africa (London, UK: Bellhaven Press, 1988), pp. 116-139, p. 127.
} 


\section{$\underline{\text { Conclusion }}$}

Third World parastatal organizations controlling the production and distribution of commodity crops have a key role and position in the national political economy and economic development of their societies, in addition to their obvious contribution to the agricultural sector. This chapter has provided the theoretical concepts and background necessary for the discussion of the evolution of these quasi-statal agencies during and following a supranational crisis that affects them directly.

I began with a broad presentation of the sometimes controversial contributions of agriculture and the state to economic development theory. This led me to explore the state-society relations literature, as it seems to be the most appropriate framework for our study. In particular, Michael Bratton's typology of interactions between the state and commodity producers will be of great use in my analysis of the coffee parastatals in Colombia and Côte d'Ivoire; it will enable me to categorize the interaction between the state and society.

What is the impact of international crises on domestic state-society relations and specifically the parastatal entities which link them? This chapter reviewed the existing literature on this topic and explores specifically the various possibilities I envision for the parastatals in times of difficulty.

Throughout the theoretical meanderings of this chapter, I noticed that the regional literatures on Africa and Latin America do not relate to each other on the issues of interest to us. Although the two continents confront a number of similar situations, the writings of scholars do not cross the geographical boundaries often. This chapter worked to bring 
together the perspectives of both Latin Americanists and Africanists to make note of common trends and problems.

The various theoretical concepts presented in this chapter will be woven into the analysis of the two case studies beginning with the very next chapter. They will enable us to deepen our understanding of the events and trends affecting the coffee parastatals in Colombia and Côte d'Ivoire. 


\section{CHAPTER IV}

\section{THE COLOMBIAN COFFEE SECTOR AND THE FEDERACION NACIONAL DE CAFETEROS DE COLOMBIA IN HISTORICAL PERSPECTIVE}

Coffee has been a central part of Colombia's economic, political and social history and development. Its production and traditions are at the very core of the Colombian economy and national culture.

This chapter explores both the reasons for the importance of coffee in Colombian life and the lengthy history of the coffee sector in Colombia. The focus of the discussion will be primarily on the state-society relations within the coffee sector. In particular, I will emphasize the historical involvement and role of the Federación Nacional de Cafeteros de Colombia (National Federation of Coffee Producers of Colombia, FEDECAFE or FEDERACAFE) in the coffee sector. As discussed in the previous chapter, I view FEDECAFE as a parastatal agency and not an association. This will become clearer with the discussion of its origins and functions.

The production of coffee began to transform the Colombian economy prior to the creation of FEDECAFE. I will thus discuss the beginnings of the coffee industry in Colombia. This historical section is not meant to explore all historical facts relating to the coffee sector from its origins to 1989 , but rather to simply highlight the significant historical phenomena surrounding the development of the Colombian coffee industry during that period. These processes affected the sector and the national economy through 1989 and laid the foundation for events in the coffee region since the collapse of the International Coffee Agreement in 1989. 
Prior to the arrival of coffee, Colombia had produced a number of other export crops such as tobacco and indigo. Colombia has also continued to cultivate other commodities for export. However, not one of these other crops alone has brought about the kind of change in economic, political, social and geographical terms, that coffee has in Colombia.

The Origins and First Consequences of Coffee Production in Colombia

It is not clear where the first coffee branch to arrive in Colombia originated. There are basically two accounts of coffee's appearance in Colombia in the mid-1800's. ${ }^{1}$ The first one posits that coffee came from Central America and was brought first to the Urabá region of Colombia. The other account, and the one that seems to be most accepted, is that coffee made its way South from the Venezuelan Andes to the region of Santander. These two regions were among the first to produce Colombian Robusta coffee. In the first years of coffee cultivation, production took place on the Eastern range of the Andes in the departments of Santander, Norte de Santander and Cundinamarca at low altitudes and on relatively large farms, which employed seasonal labor. The quality of the coffee produced was relatively low.

Between the late 1870 's and the 1890 's, the center of the coffee production area began to shift from Santander to Antioquia. This shift continued to take place over the next half century, as indicated by Table 1 .

${ }^{1}$ Jose Chalarca, El Café En La Vida De Colombia (Bogotá, Colombia: Federación Nacional de Cafeteros de Colombia, 1987), p. 5 
Table 3 Colombia: Production of Coffee by Regions, Selected Years (1874-1943) (Per cent distribution per region)

$\begin{array}{lcccc}\text { Region } & 1874 & 1913 & 1932 & 1943 \\ \text { Bolivar, Atlántico } & 0.2 & 2.4 & 0.6 & 0.5 \\ \text { Antioquia, Caldas } & \mathbf{2 . 2} & \mathbf{3 5 . 4} & \mathbf{4 6 . 9} & \mathbf{4 9 . 2} \\ \text { Cauca, Nariño, Valle } & 1.7 & 7.8 & 12.4 & 16.7 \\ \text { Tolima, Huila } & 0.9 & 5.5 & 14.4 & 15.5 \\ \text { Cundinamarca, Boyacá } & 7.5 & 18.7 & 12.4 & 9.6 \\ \text { Santander } & \mathbf{8 7 . 6} & \mathbf{3 0 . 2} & \mathbf{1 2 . 2} & \mathbf{8 . 9} \\ \text { Other areas } & - & - & 1.0 & -\end{array}$

Source: Wiliam McGreevey, An Economic History of Colombia, 1845-1930, p. 196.

This geographic displacement of the "coffee region" was due to Liberal land policies in the Antioquia region of the central Andes, the superior quality of the arabica coffee grown there (as opposed to Robusta coffee), high transport costs, taxes as well as military and guerrilla activities in the Santander area. ${ }^{2}$

The Liberal land policies in place in Colombia during the second half of the 19th century were not specifically meant to aid coffee producers but inevitably did so. These policies included the expropriation of Church lands, the sale of communal Indian lands and the takeover of government land by cultivation. ${ }^{3}$ It is by squatting and farming government land that many coffee producers were able to gain land tenure. Some coffee

${ }^{2}$ Charles W. Berquist, Coffee and Conflict in Colombia, 1886-1910 (Durham, NC: Duke University Press, 1986), pp. 230-231.

${ }^{3}$ See: William McGreevey, An Economic History of Colombia: 1845-1930 (Cambridge, England: Cambridge University Press, 1971), pp. 123-132 and Marco Palacios, Coffee in Colombia 1850-1970 (New York, NY: Cambridge University Press, 1980), pp. 56-58. 
producers also purchased land at extremely high altitudes for very cheap prices in the Antioquian region.

The land on which Colombian Arabica coffee would thrive was and remains land that could not be used for other gainful purposes. Not only is this terrain not suited for other types of cultivation, it is also not suited for large-scale production. Palacios reminds us that coffee production is a labor intensive activity and that "coffee accomodates itself to another basic institution of traditional Colombian agriculture: the peasant family." ${ }^{4}$ More than 90 per cent of the coffee land is occupied by peasant families. The key to the cultivation of coffee in these parts of Colombia is the lack of real economies of scale to be gained from either the introduction of machinery in the cultivation process or larger coffee farms. It is on this rugged terrain, in the Colombian highlands, that some of the best coffee in the world began to be produced.

In addition to the availability of land and the higher coffee grade, coffee producers had two other reasons to move to Antioquia. First, coffee produced in Santander had to be exported through Venezuela. This implied high transport costs and additional export taxes at a time when international coffee prices were decreasing. Also, the years leading up to Colombia's War of a Thousand Days in 1899 saw a significant increase in military and guerrilla activity in the region and farmers did not want to expose themselves or their families to this violence. In fact, civil peace in Santander was then connected to the region's economic fortunes.

\footnotetext{
${ }^{4}$ Palacios, pp. 12-13.
} 
While political and geographic factors greatly influenced the course of military events, it is also true that it was in the coffee-growing regions of the department of Santander, areas hardest hit by the coffee depression, that the war began and the largest battle of the war was fought. ${ }^{5}$

Moving to Antioquia thus made sense for the hard-working farmers and would have tremendous consequences for the Colombian economy.

The particular geography of the Antioquian region assured that Colombian coffee production would remain in Colombian hands. The waves of human immigration experienced by a number of other Latin American countries during the latter half of the 19th century were not experienced by Colombia in general. In addition, the few foreign immigrants and little capital that did come into the country remained on the coastal banana plantations and/or in specific mining areas. ${ }^{6}$ They did not venture to the central mountainous coffee farms. The implications of this for the national Colombian economy are tremendous. ${ }^{7}$

The most significant aspect of coffee cultivation in Antioquia is that it drew large numbers of small peasant families directly into the market. These producers had to negotiate directly with buyers of coffee and sellers of consumer goods. On the larger haciendas in Santander, most of the laborers still functioned in an informal economy. ${ }^{8}$ The introduction of numerous coffee producers into the market in combination with the

\footnotetext{
${ }^{5}$ Berquist, p. 158.

${ }^{6}$ McGreevey, pp.204-207.

${ }^{7}$ Berquist, p. 258 and McGreevey, pp. 202-205.

${ }^{8}$ McGreevey, p. 196.
} 
continuing increase in coffee production is what brought about Colombia's economic changes.

According to Helmsing,

The introduction and expansion of coffee production meant not only agricultural and rural growth and development; it also required a basic physical and economic infrastructure, which was lacking in most areas, that is roads and railways, import and export trade establishments, banking and transport, and facilities for processing coffee. In other words, coffee required and brought about considerable local regional economic transformation. ${ }^{9}$

Coffee was thus in large part the impetus for two equally important processes in Colombia. The first was the building and expansion of a real transportation network, including the introduction and use of steamships on rivers, the construction of railroads, as well as the improvement and maintenance of roads and mule trails. The other key change was the onset of national industrialization. It began in cities surrounding the coffee region and then expanded nationally.

Prior to this period of change, there had been little communication and exchange among the various Colombian regions. In fact, the various parts of the country had more contact with foreign cities than with other Colombian localities. The economic structure of Colombia in the 1800 's, according to Helmsing, was an "economic archipelago, composed of a number of isolated regions with little economic interaction among

\footnotetext{
${ }^{9}$ A. H. J. Helmsing, Firms, Farms and The State in Colombia: A Study of Rural, Urban, and Regional Change (Boston, MA: Allen \& Unwin, Inc., 1986), p. 112.
} 
themselves." 10 The regions had thus subsisted independently from one another without any real interaction.

A broader and more efficient transportation network would decrease coffee production costs over time and facilitate exports to other countries. With the shift of coffee to Antioquia, it was first the river transport business which expanded significantly. From various parts of the Antioquian region, the peasants moved their crops down the mountains to the Magdalena River to place them on ships that would carry them to their international destinations. The costs of transportation decreased on the Magdalena River by up to 23 per cent despite the quasi-monopolies which existed in river transport and other types of transport. ${ }^{11}$ According to Nieto, coffee stabilized, increased and maintained the navigation of steamships on the Magdalena River. ${ }^{12}$

The construction of railways throughout the country seems to have had a more significant impact on the costs and possibility of transport. There is disagreement as to exactly what the direct relationship is between the building of railways and the increasing coffee production. McGreevey explores the relationship between the Colombian railroad construction and the continuously increasing coffee production between 1885 and 1934 and finds a statistical relationship of +0.98 . He believes that there was a strong mutual

${ }^{10}$ Helmsing refers to Nieto Arteta to make this point, p. 108.

${ }^{11}$ McGreevey, p. 251

${ }^{12}$ Luis E. Nieto Artera, El Café En La Sociedad Colombiana (Bogotá, Colombia: El Ancora Editores, 1992), p. 18. 
interdependence of coffee and the railways during the years 1885 to $1934 .{ }^{13}$ Palacios believes that McGreevey exaggerated the impact of railroads on coffee production.

Mule trails are also an important segment of Colombian transportation because of the country's geography. Mules are still used today to move coffee out of the steepest areas of coffee production. It is more difficult to determine the exact impact of mule trails on the movement of coffee or the national economy. At the beginning of the 20th century, President Reyes put in place a specific plan to increase by 780 miles the mule trails in existence on the Colombian territory.

The creation of this national network involving railroads, rivers and mules did not only facilitate exports of coffee and imports of consumer products, it also increased transportation and communication among the detached regions of Colombia. In addition, it provided a large number of jobs to those involved in the construction of the means of transportation, for example, to those who lived along the Magdalena River or the railroad paths and in the ports of Barranquilla and Cartagena. ${ }^{14}$ Thus, no matter the exact financial implications of this much larger transportation network for coffee producers, it is important to keep in mind that it is the export of coffee which prompted the creation and expansion of this national network of transportation.

As mentioned previously, the other key process that got underway in Colombia as a result of the increasing coffee production was industrialization. This process started out as a regional one and then expanded nationally. Industrialization would not have taken

\footnotetext{
${ }^{13}$ McGreevey, p. 253.

${ }^{14}$ Nieto, p. 19.
} 
place in the same fashion as it did if there had been more significant foreign labor and capital involved in the production and export of the coffee bean. In other words, the accumulation of capital by Colombian producers meant that the cash they earned would be spent at least in part in Colombia and would drive the industrialization process. Coffee farmers exported their coffee crops and with their revenues, purchased consumer goods of all kinds, some imported and some locally produced. According to Helmsing,

The strong development of coffee production and exports enabled diversification toward industrial activities and stimulated it in various ways. First, the structure of coffee production was less concentrated than that of any other export crop, generating a more favorable distribution of (monetary) income, thus constituting an important source of demand for manufactured products. Second, increasing coffee exports contributed the foreign exchange necessary to finance the imports of industrial machinery and raw materials. ${ }^{15}$

McGreevey uses the case of textile importers to illustrate the Colombian industrialization process. ${ }^{16}$ The cost of purchasing and transporting imported textiles to Antioquia was quite high. As a result of the steep costs and prices involved, the importers explored the opportunities to create local textile manufacturing and, with the profits earned from trade, began to invest in such an industry. "The first large-scale textile mill began production in 1906 with 102 looms and 300 employees" $^{17}$ and the industry grew from there. It is therefore in the coffee region that the possibilities and capital first existed for

\footnotetext{
${ }^{15}$ Helmsing, p. 113.

${ }^{16}$ McGreevey, p. 199.

${ }^{17}$ McGreevey, p. 119.
} 
industrialization. Even today, the city of Medellin located in the coffee region is one of Colombia's main manufacturing centers.

Industrialization and the creation of national transportation networks are key parts of Colombia's economic development. They are not, however, separate processes; on the contrary, they are closely linked. The creation of new and better transportation routes allowed for coffee to be exported and money to be made. This, in turn, created the possibilities for imports of industrial products to be used in the nascent Colombian industries.

The historical, geographic and economic changes which took place in Colombia between the 1870 's and the 1930 's as a result of Colombian coffee production had a significant political implications for Colombian unity, starting at the turn of the century. According to Helmsing, "the development of coffee as the major export product generated new forces that called for a unitary system of government." 18

For a number of years, as could be seen in Table 1, a significant amount of coffee was being produced in both Santander and Antioquia. The political leanings of the producers in these two geographic regions of the country were, however, different. The large coffee producers in Santander had been predominantly affiliated with Colombian Liberal Party, whereas the much smaller coffee producers in Antioquia were more linked to the Conservative Party. This meant that both traditional Colombian political parties would concern themselves with the well-being of the coffee sector. ${ }^{19}$ The fact that the

\footnotetext{
${ }^{18}$ Helmsing, p. 110

${ }^{19}$ Berquist, p. 258.
} 
green bean was grown in different geographic regions added to the general interest in the coffee sector at the national level. ${ }^{20}$

In addition, the continuing increase in coffee exports implied significant revenues in the form of customs taxes for the national government such that it actually was in a financial position to fulfill some of the needs of the growing economy. The new level of state income would also have the added benefit of making the country eligible for foreign loans. $^{21}$

The political dynamics in play, the growing state revenues, along with the needs of the coffee sector (as described on page 5) created the impetus for a stronger, more efficacious, national state and government. Among other things, the country's leader in the 1880 's, Rafael Nuñez, created a national army, set in motion the work on a Colombian transportation network and attempted to establish a national banking system. Undeniable tensions remained between the increasingly powerful national government and the regions with regard to their respective powers. Regions had until this point in Colombian history been the key political entities. Helmsing summarizes some of what was involved in the consolidation of the central state:

the growing strength of the export sector directly and indirectly gave further support to the development of central state power and institutions. It became urgently necessary to develop infrastructure on a large and interregional or national scale (railways, roads, harbors, monetary system, and so forth); this called for greater powers for central government at the costs of the departments, although without considerable expansion of the

\footnotetext{
${ }^{20}$ Helmsing, p. 112.

${ }^{21}$ Helmsing, p. 126.
} 
role of the state as a whole. The War of a Thousand Days (1899-1902)

brought the defeat of traditional regional power. ${ }^{22}$

Even after the War of a Thousand Days, it took several decades for this unitary state to establish itself and structure the national economy. In the same way, it is over the course of 30 or more years that the processes of industrialization and transportation networks really took shape in the coffee region.

\section{The Creation of the Federación Nacional de Cafeteros de Colombia}

While all of these important national processes were taking place in Antioquia and the surrounding areas, coffee production and exports continued to grow. From 1910 to 1930, production rose from 0.5 million bags of coffee to 1.5 million bags; coffee represented 80 per cent of the value of Colombian exports in $1930 .^{23}$ The national government was interested in assisting coffee cultivation as it was providing such important state revenues and was moving the country forward in such dramatic fashion. The state would thus not be opposed to the presence of an entity which would organize coffee production and interests; on the contrary, the state would support the creation of such an organization. ${ }^{24}$

${ }^{22}$ Helmsing, p. 110-111.

${ }^{23}$ Bennett Koffman The National Federation of Coffee-Growers of Colombia (Charlottesville, VA: University of Virginia, Dissertation in Political Science, 1969.), p. 73. He discussed at length the creation of the Federación Nacional de Cafeteros in his dissertation.

${ }^{24}$ Koffmann, p. 74. 
The Federación Nacional de Cafeteros de Colombia can be traced back to the Sociedad de Agricultores de Colombia (Society of Farmers of Colombia). This organization was founded in the 1870 's by large landowners who spread the basic precepts of the Liberal economic doctrine and shared information about tropical agriculture and international commodity markets. ${ }^{25}$ By principle, the group aimed to remove the obstacles faced by Colombian farmers. This club of landowners functioned quite well as long as there was no state intervention in agriculture. It became clear with the advent of the central state and other interests rising to the national level that a serious national organization was needed to work on behalf of the coffee sector as a whole. ${ }^{26}$

These large landowners therefore created the Federación Nacional de Cafeteros in July 1927 at the second Coffee Congress in Medellin with the key support of the national government. London elaborates:

When FEDECAFE was founded in 1927, coffee was a spatially extensive, extremely heterogeneous export sector that had grown mostly in the previous 15-20 years. Problems with quality control, market volatility, labor unrest, and so on underscored a long felt need on the part of the Colombian bourgeoisie, and Antioqueño merchant-industrialists in particular, that the coffee sector had to be efficiently organized if it was to be a dependable component of the national economy. So FEDECAFE was formed and charged with the task of reigning in this dispersed, complicated commodity production sector and the making of it a predictable, malleable and profitable industry. The means to do this were to establish financial and technical control over the industry. ${ }^{27}$

${ }^{25}$ Palacios, p. 218

${ }^{26}$ Palacios, p. 219.

${ }^{27}$ Christopher London, "Class Relations and Capitalist Development: Subsumption in the Colombian Coffee Industry, 1928-1992," Paper presented at the 1995 meeting of the Rural Sociological Society, p. 8. 
The mission of FEDECAFE would thus be key for the future of the coffee sector.

Errazuriz uses a speech given by the General Manager M. Ospina Pérez at the Fourth Coffee Congress in 1932 to outline the all-encompassing activities of the Federation. First, FEDECAFE dealt with an extremely large variety of issues, relating to agriculture, industry, commerce, finance, statistics, law, transport, propaganda, and information. Second, in order to manage the coffee sector, FEDECAFE needed to communicate regularly with its own local and regional offices as well as the various depositories of coffee throughout the country, the research and education centers, the customs offices, railway stations, river ports, the various Ministries involved, Colombian consuls abroad, coffee exporting firms, roasters, etc. ${ }^{28}$ The web to be created by FEDECAFE and around it was thus an extremely broad one, involving numerous different areas of the Colombian economy and an important number of other agencies.

In theory, FEDECAFE was to have an extremely wide range of responsibilities: represent all coffee producers, propose government policies helpful to the sector, set reasonably high producer prices, control the quality of the coffee for export, oversee the marketing of coffee, including advertising

${ }^{28}$ Errazuriz, pp. 90-91. 
and propaganda, represent Colombia at international coffee negotiations, and assist coffee producers as much as possible.

A determining factor in the activities and capabilities of the Federation was and remains the Colombian state, which has held an absolutely key position in the Federation's affairs. Since the creation of FEDECAFE, four related issues have been and continue to be at the forefront of relations between the state and the Federation. The first involves the role of the state in the decision-making apparatus of the Federation. Bates lists the other three: taxes, currency valuation and trade policy. ${ }^{29}$ As I review the historical evolution of FEDECAFE, I will expand on each one of these areas. At this point, however, it is necessary to discuss taxes and FEDECAFE's financing since this issue impacts the very roots of the Federation's functioning. It is worth noting that a previous attempt at creating an organization such as FEDECAFE failed in 1920 specifically because of lack of funding.

At the coffee congress which created FEDECAFE, the 29 representatives of 15 coffee-producing departments issued a vote on the specific issue of taxes. Their opinion was that under no circumstances should taxes be levied on the coffee producers for the creation and maintenance of the Federation. Following the congress, however, the government, represented by the Minister of Industry, completely rejected this vote and put forth the

${ }^{29}$ Robert Bates, Open-Economy Politics: The Political Economy of World Coffee Trade (Princeton, NJ: Princeton University Press, 1997), p. 64. 
following ultimatum: "Either accept the tax of ten centavos per bag, or there will be no Federation." ${ }^{30}$ The leaders of the new Federation had no choice but to accept what their representatives had specifically rejected; they did, however, obtain something in return. The tax to be levied on each sixty kilogram bag of coffee would be earmarked specifically for the coffee industry. In other words, the tax revenues stemming from coffee exports would contribute directly to the coffee region's development and the welfare of its inhabitants. A sum equivalent to the taxes levied would be entrusted to the Federation by the state for a variety of purposes: propaganda, technical instruction for growers, health of coffee producers, the building of warehouses for the storage of coffee, research missions, establishment of domestic and foreign roasters, publications, statistical reports, etc. ${ }^{31}$ It is thus through the state that the Federation received its funding starting in 1928.

The government in place at the end of the 1920's, however, was well aware of, and even fearful of, the power being placed in FEDECAFE's hands. In order to ensure that it would maintain a minimum of control over the Federation, the state constrained it even further. Five of the eleven members of the National Committee of the Federation would have to be Ministers from government ministries, such as Agriculture and Industry. In addition, the state issued a decree with the following requirements, according to Koffmann:

\footnotetext{
${ }^{30}$ Koffman, p. 82.

${ }^{31}$ Koffman, p. 82.
} 
Most notable were new requirements that the Federation's general plan of activities would require approval by the Ministry of Industries, which would have veto power over modifications of the plan and over the Federation's annual budget, and would have an undefined supervisory control over its services and would have to agree to appointment of its representatives in foreign countries. ${ }^{32}$

This specific decree caused the resignation of all FEDECAFE national committee members. A number of those individuals, however, did return to their posts supposedly only to ensure that the Federation would not just be eliminated. Palacios writes: "its internal structure changed and by 1934 and 1935 the FNCC was a closed institution, controlled from above." ${ }^{133}$

These tensions between the state and FEDECAFE are indicative of the state's tenuous position towards FEDECAFE. The state wanted to ensure that it maintained adequate control over the organization, while at the same time giving it great responsibilities over the key sector of the growing national economy.

The other key relationship for FEDECAFE is obviously the one with the actual producers, especially the smaller ones. The latter were not involved in the least in the creation of the organization. According to London, "the organization's leaders were concerned over the creation of a local base and mass membership, for these certainly had not preceded the national committee and directorate." ${ }^{34}$ FEDECAFE was, after all, claiming to be the representative of their interests. The organization's ability to reach out

\footnotetext{
${ }^{32}$ Koffman, p. 82.

${ }^{33}$ Palacios, p. 219.

${ }^{34}$ London, p. 85.
} 
to all coffee producers would be one of the determinants of its success. Considering that the state was for practical purposes absent from the Colombian coffee regions at that time, any outreach from FEDECAFE to the small producers would be preferable to the previous void. Errazuriz believes that FEDECAFE filled at least part of the vacuum which existed at that time in the relations between the Colombian state and the rural world..$^{35}$

London is not as optimistic as Errazuriz regarding the representation of coffee growers by the Federation. ${ }^{36}$ Membership was free specifically to enable all coffee producers to be part of the organization. London reminds us that anyone who has an interest in coffee could become a member of FEDECAFE, meaning that commercial exporters, for example, could join and ask to be represented by the Federation.

The structure created by FEDECAFE to fulfill all of its responsibilities did and does from a theoretical point of view attempt to involve the peasants in the processes of decision making of the Federation. The Federation was to be led by a Gerente Nacional (General Manager) who would oversee all of the organization's structure and operations. The Congreso Nacional de Cafeteros (National Congress of Coffee Producers) would make the decisions to be implemented by the General Manager and his Comite Nacional de Cafeteros (National Committee of Coffee Producers).

The relationships between the Manager, the Comites Departamentales (Regional Committees) and the Comites Municipales (Local Committees) were supposed to be two-

\footnotetext{
${ }^{35}$ María C. Errazuriz, Cafeteros y Cafetales Del Libano: Cambio Technológico y Diferenciación Social en Una Zona Cafetera (Bogotá, Colombia: Universidad Nacional de Colombia, 1986), p. 88.

${ }^{36}$ London, p. 87.
} 
directional. In other words, the Manager and the regional committees would transmit information to the municipal entities while at the same time receiving input in return from the municipal committees. For Palacios, however, this part of FEDECAFE's structure resembles a "wheel of fortune," with half the departmental committees elected by the national committee and half the municipal committees chosen at the departmental level. ${ }^{37}$

\section{The Colombian Coffee Sector from 1930 to 1958}

Having laid out the origins, goals, and structure of the Federation, let us now focus on its actions and interactions within the context of domestic and international events affecting the Colombian coffee sector. Throughout this discussion, I will pay particular attention to FEDECAFE's relationship with the state and its ability to control and/or guide the coffee sector.

As noted above, the National Federation of Coffee Growers was to be involved in numerous aspects of the coffee production and export process; it went to work to "rationalize the market." ${ }^{38}$ It began by creating the Almacenes Generales de Depósito (General Storage Stores, AGD), which were to stock the coffee purchased by the Federation. By controlling the stocks in storage, FEDECAFE hoped to influence international prices. More importantly, though, FEDECAFE wanted to portray itself as a reliable buyer for Colombian peasants, who could always sell their quality coffee to the Federation and therefore earn a minimum income regardless of world prices.

\footnotetext{
${ }^{37}$ Palacios, p. 219.

${ }^{38}$ Palacios, p. 220.
} 
In addition, FEDERACAFE used these stores to control the quality of Colombian coffee. ${ }^{39}$ Different quality grades of coffee co-existed and continue to co-exist in Colombia. Quality can be determined by the type of coffee produced, the soil on which it is grown, the care given to the coffee plants, the use of fertilizers, if any, etc. As a result of varying quality grades, in the 1920 's, coffee beans sold in certain regions such as Antioquia were known to be better and were sold at a higher price than those produced in other areas such as Bucaramanga. Foreign exporters were interested in coffee produced in places where they could depend on the quality. As a result of these factors, significant numbers of farmers who were producing lower grades of coffee began to take their coffee to towns other than their own, where the quality of the coffee was in general better and where they would get a better price for their lower quality coffee. The end result was that there was no guarantee on the quality of coffee originating from any part of Colombia.

As a result of this increasingly serious problem, FEDECAFE was given authorization to control the quality of coffee in the very accord that created it. The Federation would be the only entity that could stamp "CAFE DE COLOMBIA" on sixty kilogram bags of the bean. It would control points of origin and have the power to penalize those who tried to get around the laws. ${ }^{40}$

Beginning in the early 1930 's, FEDECAFE has always been concerned with the exchange rate of the Colombian peso against the dollar as it had a direct impact on the revenues of coffee producers, especially when world coffee prices were low. By devaluing

\footnotetext{
${ }^{39}$ London, p. 107.

${ }^{40}$ Bates, pp. 62-63.
} 
the currency, the government could increase the income of coffee farmers. Following the crisis of 1929, and under unrelenting pressures from the Federation of Coffee Growers, the national government devalued the Colombian currency several times starting in March 1932. These types of devaluation help coffee farmers but hurt industrialists trying to import commercial products and export their own products. It has been up to each Colombian government faced with the decision to devaluate or not to decide which group it wishes to assist primarily.

FEDECAFE also had an increasingly important role to play in Colombia's international relations. It directed a portion of foreign trade policy and in doing so often came into direct conflict with the government's positions, especially vis-a-vis Brazil, the largest coffee producer, in the 1930 's. In order to maintain relatively high world prices for its key export commodity, Brazil was withholding coffee from the market. Colombia benefited from Brazil's actions. Bates uses rational choice theory to explain the Colombian government and FEDECAFE's preferences. ${ }^{41}$ The government was in favor of helping Brazil by also withholding stocks, while the Federation and coffee growers wanted to continue as free riders. Finally, in 1936, the government imposed its preference on the Federation and Colombia signed an agreement with Brazil regarding cooperation on the withholding of stocks.

1940 was an important year for the Federation for two reasons. First, its leaders represented Colombia in the negotiations for the Quota Pact in Washington, DC, and did so quite well. Because of World War II, the European coffee markets had disappeared

${ }^{41}$ Bates, p. 73. 
and the Latin American coffee producing countries agreed to specific production quotas for the North American market. ${ }^{42}$ Second, as a result of this Quota Pact signed with the United States and other Latin American countries, the Fondo Nacional del Café (National Coffee Fund, FNC) was created as a mechanism to guarantee Colombia's compliance with this Pact. The FNC was created as an account in Colombia's national Treasury to be managed by the Federation on multi-year contracts with the state as a public service for the purposes of buying, storing or selling coffee according to the agreements signed between the state and the Federación.

The creation of the FNC implied the partial fusion of state and FEDECAFE funds and gave the Federation unprecedented financial strength. In addition, it provided FEDECAFE with the possibility to intervene in decision-making regarding coffee policies at a level unequaled in Colombia. Beyond the political implications of this mutual dependence between FEDECAFE and the state, the former was perceived during these years as the only entity that could handle the complexities of the coffee industry. ${ }^{43}$ FEDERACAFE was slowly establishing the means by which it could control the coffee sector, specifically in the financial arena.

The Quota Pact disintegrated in 1945, but the FNC remained in existence. It was assumed that new retention schemes would be required as part of other international agreements. In addition, coffee price fluctuations on the markets were quite significant. ${ }^{44}$

\footnotetext{
${ }^{42}$ Escobar, p. 46.

${ }^{43}$ Errazuriz, p. 94.

${ }^{44}$ Palacios, p. 224.
} 
Colombia was also experiencing more exchange rate instability; from 1948 to 1967 , the currency was devalued six times.

The transformation of Colombia's economic, political and social landscape resulting in the industrialization of parts of the coffee region, the creation and strengthening of a central state to the detriment of regional power, in addition to changes in the Colombian countryside itself, transformed the country in a radical way.

Unfortunately, these processes, in combination and to varying degrees, also brought about the most violent episode in Colombian history, la Violencia. It began, on the surface, with a confrontation between the Liberals and Conservatives and the assassination in Bogotá in 1948 of an important Liberal leader, Jorge Eliécer Gaitán. From there, it quickly spread through many parts of the country, resulting in bands of peasants killing one another or fighting against units of the army or police. The violence had no specific direction and fed on itself; it lasted longer in some areas than it did in others. By the end in 1958, 200,000 people were dead and two million people had migrated from rural areas to urban centers. ${ }^{45}$

The Violencia marked the end of an era for the Colombian coffee region. The region as a whole suffered important losses. A large number of farmers fled to save their lives and numerous coffee farms were destroyed or left in disarray. In addition, the producers who did remain on their lands did not plant new coffee trees to replace the old ones as a result of the reigning uncertainty. The quality and quantity of the coffee beans

${ }^{45}$ For more on La Violencia, see: Jenny Pearce, Colombia: Inside the Labyrinth (London, England: Latin American Bureau, 1990), pp. 49-66 and Maria Errazuriz, op. cit., pp. 101-130. 
produced during this time fluctuated wildly from year to year. From 1952 to 1956 , the Colombian coffee sector somehow experienced a small boom.

During these bloody years, FEDECAFE was one of the only national institutions which actually continued to function. While annual congresses were cancelled from 1946 to 1955 , the organization continued its work. During this time period and in part as a result of it, the Federation became the central institution of governance in the coffeeproducing areas. ${ }^{46}$

\section{The Colombian Coffee Sector from 1959 to 1989}

In order to end the terrible Violencia, the two main political parties compromised by creating the Frente Nacional (National Front, FN). Their compromise included three provisions. For the next sixteen years, beginning in 1958, the Liberal and Conservative parties would take turns at the presidency, alternating every four years. In addition, government posts would be equally divided between the two parties and a two-thirds majority would be required for legislative decisions at any level of the government. This system excluded other parties from participation but did provide the country with some level of political stability. ${ }^{47}$

The economic policies of the National Front would obviously change with the different governments. The real goal of many of these different governments, however,

${ }^{46}$ Errazuriz, p. 119.

${ }^{47}$ Bruce Bagley, "National Front and Economic Development" in Robert Wesson (ed.), Politics, Policies, \& Economic Development in Latin America (Stanford, CA: Hoover Institution Press, 1984), pp. 124-160. 
would be the same: to attempt to reduce the dependence of the Colombian economy on coffee. According to Bagley, "coffee was the country's major export, and its dependence on this crop produced boom and bust cycles and chronic foreign exchange problems that severely inhibited the country's overall economic development." ${ }^{48}$ The problem was to reduce the country's dependence on a primary export commodity while at the same time depending on that very commodity for foreign exchange earnings and income.

The first National Front government led by Conservative President Guillermo León Valencia began an Import Substitution Industrialization Phase (ISI) by imposing external tarriffs, exchange controls and other protectionist measures, which did not directly affect the coffee sector. Industrial production in the steel and chemical industries did increase as a result but not fast enough for the policy to be pursued beyond the mid-1960's when the low price of coffee on the world markets reduced incoming foreign exchange. During this time, the government and FEDECAFE both began to work on a major agrarian reform in order to diversify and modernize Colombian agriculture as a whole. FEDECAFE, which as we have seen had focused mostly on the financial and political aspects of the coffee sector at the national level up to this point, shifted its focus in the early 1960 's to the actual site of coffee production, the rural world.

Up to this point, coffee had been produced very traditionally by the small and medium producers, who had received very little, if any, technical advice as to how to grow their crop. FEDECAFE had not particularly concerned itself with the conditions of production. According to Palacios, the traditional methods of cultivation included: "a)

\footnotetext{
${ }^{48}$ Bagley, p. 137.
} 
intensive use of labor with low productivity (social division of labor is expressed within the family structure; cultivation methods are mediocre and traditional); b) extensive use of the soil due either to a low seeding density (1000 to 1500 trees per hectare) or to the abuse of inter-planting, which exhausts the fertility of the soil; c) low use of fertilizers: 12 $\mathrm{kg} / \mathrm{ha}$ in 1956 ; d) low control of soil erosion; and e) scant use of pesticides. ${ }^{49}$

In response to these not so productive methods of cultivation and the sad state of the coffee region as a whole following la Violencia, the Federation began to work on ways to improve the productivity and living conditions of the small coffee producers. It proposed a number of goals for its larger and improved technical department, including: a decrease in coffee production costs and an increase in the yield of each production unit; the elimination of marginal production zones by replacing coffee with other, more promising, crops; the diversification of crops and the promotion of animal farming in the coffee region for the explicit purpose of increasing the producer's income and avoiding income fluctuations; empowerment of the producer to obtain credit for the improvement and enlargement of his production area; but above all, a substantial improvement in the quality of life of his family. ${ }^{50}$ FEDECAFE thus was seeking to create a new kind of farmer, one who produced more coffee with less land and raised other crops on the side, one who used credit to technify his farm but still had a stabler and higher income while improving the conditions of life for his family.

${ }^{49}$ Palacios, p. 235.

50 "El Servicio de Extensión Agricola en la Federación de Cafeteros," Revista Cafetera, 1960, p. 59. 
In order to fulfill these often contradictory goals, FEDECAFE set up an extensive Servicio de Extensión (Extension Service) in 1962 to assist farmers in coffee production. It is worthwhile noting that, upon its creation, FEDECAFE had developed a very small extension service which consisted of 44 ambulatory expert extension agents for the entire coffee region. They came into a town at the request of a large producer and presented a number of cultivation methods to these producers and hopefully a few others from surrounding towns. ${ }^{51}$ In the expanded extension service the Federation put together, the extension agents would be located permanently in coffee-producing towns and visit specific veredas (neighborhoods) each day.

In this attempt to increase the productivity of Colombian coffee farms and improve the lives of coffee producers, FEDECAFE created a whole structure to augment technical assistance. The Centro Nacional de Investigaciones del Café (National Center for the Research on Coffee, CENICAFE) is a key component of this structure as it provides the scientific and technical information for the extension agents to pass along to the peasants. Their first major contribution to the coffee sector was the creation of a new, more productive type of coffee, caturra, which required less spacing in between coffee plants than the type of coffee traditionally grown until then and would also produce more coffee beans per tree. It did, however, require the use of fertilizers.

Another key institution created during this period is the Fundacion Manuel Mejia, which opened in 1965 with the goal of educating producers and extension agents. Its

${ }^{51}$ Christopher London, The Cultural Politics of Technical Change in Colombian Coffee Production (Ithaca, NY: Cornell University, MA Thesis, 1994). 
mission, according to its brochure, is "to make coffee producers enterprising, efficient, and active participants in the processes of social development." ${ }^{52}$ Its mission went beyond simply teaching its students coffee-growing techniques and included the desire to help coffee producers lead better lives in the rural world.

Similarly, in addition to the technical assistance FEDECAFE was providing to the coffee producers, FEDERACAFE was also interested in improving their rural living conditions. "FEDERACAFE also undertook the provision of infrastructure far in excess of the normal purview of a producers' organization and in effect functions like a minigovernment among its coffee constituents, collecting coffee payments in kind; providing schools, nursery schools, hospitals and roads; extending electrical power lines; and operating collecting centers, supermarkets and banks." ${ }^{53}$ These actions, along with FEDECAFE's official representation of Colombia in the International Coffee Agreement negotiations continued to increase the organization's "quota of legitimacy." ${ }^{44}$

The Law 444 of 1967 effectively ended the official ISI approach to development and brought about an attempt at export-led growth. ${ }^{55}$ This law had three effects. First, it established a "crawling peg" rate for the Colombian peso, which meant that the peso

${ }^{52}$ Fundacion Manuel Mejia, Brochure, 1995.

${ }^{53}$ Vinod Thomas, Linking Macroeconomic and Agricultural Policies for Adjustment with Growth: The Colombian Experience (Baltimore, MD: The Johns Hopkins University Press for the World Bank, 1985), p. 132.

${ }^{54}$ Escobar, p. 62

${ }^{55}$ Carlos Juárez discusses this in depth in his article "Trade and Development Policies in Colombia: Export Promotion and Outward Orientation, 1967-1992," Studies in Comparative International Development, 28, 3 (1993), pp. 67-97. 
would undergo small but regular devaluations to keep in line with inflation. Second, export diversification was to be encouraged and third, Colombia would for the first time regulate multinational corporations operating in the country. It is important to note that even though the government was pushing export strategies, it did continue to protect the growing Colombian industries. There were growing tensions between representatives of the coffee sector and industrialists.

As a result of these strategies, Colombia's dependence on primary export commodities and particularly on coffee was reduced. According to Lucier, in 1960, 98 percent of Colombia's exports were primary commodities, with coffee representing 75 per cent of those exports. In 1975, primary goods only made up 79 per cent of Colombia's exports and coffee was only 46 per cent of that ${ }^{56}$ Other primary exports from Colombia included: oil, sugar, bananas, emeralds and cut flowers. The country was slowly industrializing and diversifying its exports.

The year 1975 brought about new opportunities and challenges for the Colombian economy. A frost in Brazil that year caused coffee prices to increase from $\$ 0.65$ in 1975 to $\$ 2.00$ in 1977 , a price coffee producers had never seen. In 1976 alone, Colombia exported $\$ 8.1$ billion worth of coffee, as compared to $\$ 2.1$ billion exported in 1966 . The figure for 1976 represented only a 5 per cent increase on the amount exported in $1966 .{ }^{57}$

${ }^{56}$ Richard Lucier, The International Political Economy of Coffee: From Juan Valdez to Yank's Diner (New York, NY: Praeger Publishers, 1988).

${ }^{57}$ Gilberto Arango Londoño, Por Los Senderos del Café: De la Gran Bonanza a la Peor Crisis, 1975-1993 (Bogotá, Colombia: Ediciones Fondo Cultural Cafetero, 1994), p. 38. 
According to Arango, the price increase should not be considered a bonanza but rather a much deserved and long overdue price increase for Colombian peasants. ${ }^{58} \mathrm{He}$ argues that the price of coffee per pound in the United States had not increased at all in 15 years despite inflation and that it was time for the price of coffee to go up.

For the first time, Colombia was faced with an overflow of international reserves, as opposed to its usual foreign exchange scarcity. As a result, the money supply expanded between 20 to 30 percent each year; this implied chronic inflation. ${ }^{59}$ "The irony in postfrost Colombia was that domestic and international dependence on coffee was renewed." ${ }^{60}$ This coffee boom was thus not entirely positive for the Colombian economy.

The state and FEDECAFE renegotiated their contract regarding the management of funds in the National Coffee Fund towards the end of the coffee bonanza, in 1978. The boom had strengthened FEDECAFE once again and gave its leaders a more powerful position from which to renegotiate the terms of the agreement.

As would be expected, the high coffee prices during these few years encouraged farmers to grow more coffee. This, in combination with the planting of the more productive caturra coffee, as encouraged by FEDECAFE, caused Colombia to see a dramatic increase in its annual coffee production in the early years of the 1980 's. As stated in its contract, the Federation was obliged to purchase all the coffee of minimum quality that the peasants wanted to sell. However, because of the International Coffee

\footnotetext{
${ }^{58}$ Arango, p 52.

${ }^{59}$ Reveiz and Perez, p. 278.

${ }^{60}$ Lucier, p. 229.
} 
Agreement, Colombia was not allowed to sell more than its quota of coffee. FEDECAFE thus had to start storing a large number of bags of coffee, two to three million bags annually. By September 1984, FEDECAFE had 12.2 million bags in stock. ${ }^{61}$ There was a slight chance that the Federation's variable quota with the ICA would increase because of these stocks, but with the number of coffee-producing countries increasing, this was unlikely. FEDECAFE knew that even a boom such as the one experienced in the mid1970 's would not provide an opportunity to sell all this stored coffee. Colombia's exports had actually not gone up that much during the "bonanza."

What was the Federation to do? It had encouraged the producers to be more productive. The Federation explored a number of options to reduce production, even just on the short term. ${ }^{62}$ The first option was encouraging coffee producers to stump their coffee trees every six years. This would imply that 80,000 trees would be out of production in any given year. This could only be a short-term solution as stumping encouraged the tree to produce more a few years later. FEDECAFE also invited farmers to use the shade method for their coffee cultivation. This method involved the planting of trees such as banana trees to provide shade for the coffee bushes; it produced less coffee but its quality was superior.

In addition, FEDERACAFE continued its campaign in favor of diversification although farmers were not particularly interested in hearing it. Although it would be in FEDECAFE's interests for coffee producers to cultivate other crops and therefore less

\footnotetext{
${ }^{61}$ Thomas, p. 108.

${ }^{62}$ Thomas, p. 113-116.
} 
coffee, the farmers saw no reason to switch to another crop. They enjoyed the security of knowing that the Federation would buy however much coffee they could produce.

Despite the difficult times for FEDECAFE and the Fondo, the internal price of coffee for growers was increased. In 1983, for example, the price rose from 12,100 to 13,900 pesos for 125 grams. $^{63}$

To complicate matters, in 1983, the roya, a form of coffee leaf rust, appeared in Colombian coffee regions after having affected a number of areas in Central and South America in previous years. By the end of $1984,4.5$ per cent of coffee-producing areas were affected by it. Production was forecast to be down by 15 to 20 per cent for 1984 . The rust having appeared in other parts of the Latin American region, FEDERACAFE had already spent resources to find ways to fight the disease. It was thus ready with a new, roya-fighting variety of coffee, variedad Colombia, when news spread of its arrival in the Colombian Andes. Of course, whatever impact the roya would have on the crop, Colombia had the stocks to make up the difference. ${ }^{64}$ The roya however affected peasants who were faced with the costs of a smaller coffee crop and, for those who could afford it, the costs of planting the variedad Colombia coffee.

The year 1985 was not a particularly good year for FEDECAFE for two reasons. First, the organization was involved in a scandal in the first part of the year. ${ }^{65}$

${ }^{63}$ Economist Intelligence Unit, Quarterly Economic Review of Colombia and Ecuador, 4, 1983, p. 13.

${ }^{64}$ Vinod Thomas discusses these issues more in depth in his work, pp. 106-118.

${ }^{65}$ Economist Intelligence Unit, Quarterly Economic Review of Colombia and Ecuador, 2, 1985, p. 10. 
FEDECAFE, the guarantor of the quality of Colombian coffee, had approved for shipment to the U.S. 3,000 bags of coffee of inferior quality. The US Food and Drug Administration cracked down on shipments from Colombia. Charges also emerged that FEDECAFE had been involved in money laundering. All of this resulted in the firing of the sub-director of FEDECAFE's export section but for the first time cast doubts on the organization's probity.

Second, in part as a result of FEDECAFE's push for diversification of crops in the coffee region,

some 800 small and medium sized producers, from 14 departments, have formed a new organization, the Unión Cafetera Colombiana (Colombian Coffee Union, UCC). They do not like FEDECAFE's enthusiasm for crop diversification and criticize its internal pricing system and the absence of a rust control policy. One of its organizers, ex-minister Fernando Londoño, has accused FEDECAFE of being anti-democratic and oriented towards the interests of the large coffee producers. ${ }^{66}$

However, not all coffee producers were satisfied with the representation and policies provided to them by the Federation. UCC was the first such organization to surface and to place itself opposite FEDECAFE. From the perspective of these farmers at least, FEDECAFE is not an organization representing their interests, but rather those of the large producers and the elites.

A mini-bonanza in 1985-1986 provided a bit of financial relief to FEDECAFE and the Fondo Nacional Cafetero. The latter had been steadily diminishing as a result of the high prices it had maintained for the farmers despite lower world prices and the roya. The

${ }^{66}$ Economist Intelligence Unit, Quarterly Economic Review of Colombia and Ecuador, 3, 1985, p. 11. 
Palacios plan was put in place by the Minister of Finance to dispose of the windfalls in three ways ${ }^{67}$ The first third would go to recapitalize the Fondo; the second third would go to producers who were expected to purchase Titulos de Ahorro Cafetero (Certificates of Coffee Savings, TAC) to strengthen the Federation; and the remaining third would go to public utility companies which had built and would continue to build infrastructure in the coffee areas.

The policies pursued by the government in coordination with FEDECAFE have ensured that Colombian coffee production remains high. A record production year was seen in 1987 for example with $12,974,000$ bags of coffee produced. The Colombian coffee industry was thus in a very strong position prior to the collapse of the International Coffee Agreement.

\section{$\underline{\text { Conclusions }}$}

In the first part of this chapter, following a review of the historical importance of coffee in Colombia, we discussed the creation, organization, and goals of the National Federation of Coffee Growers of Colombia. We also looked at how the organization went about inserting itself into, and strengthening its position at, the very center of the national coffee production system in Colombia by taking on key roles with respect to the finances, marketing and policy-making for Colombian coffee. From there, it moved its effort to the actual site of coffee production, the rural world, and worked to create a new kind of

${ }^{67}$ Economist Intelligence Unit, Quarterly Economic Review of Colombia and Ecuador, 2, 1986, p. 9. 
Colombian farmer while at the same time protecting the farmer from the fluctuations of the world markets. It is clear that coffee production and FEDECAFE were very instrumental in Colombian regional and economic development.

I believe that on the eve of the collapse of the International Coffee Agreement, FEDECAFE definitely had an important position at the national level. Its political and economic leverage should not be underestimated. No other organization, state-sponsored, or otherwise, has provided the coffee peasants with the infrastructure they obtained from FEDECAFE between the 1960's and the end of the 1980's. The creation of another organization by a small group of peasants, however, shows that at least some peasants did not feel that FEDECAFE represented their interests adequately. Considering the harsh living conditions of the peasants in the mountainous areas of the Andes, it is possible that there is some amount of indifference towards the organization among peasants as the primary concerns for them are short-term and remain coffee production and putting food on the table.

The Federación Nacional de Cafeteros de Colombia is thus at the center of the coffee sector and a very active participant in state-producer relations. In a way, it was trying to be all things to all people. In the next chapter, I will review the changing role of FEDECAFE vis-avis- the producers and the state during the major crisis experienced by the Colombian coffee sector. 


\section{CHAPTER V}

\section{THE COLOMBIAN COFFEE SECTOR AND THE FEDERACION NACIONAL DE CAFETEROS DE COLOMBIA SINCE 1989}

The collapse of the International Coffee Agreement in September 1989 was a real turning point for the Colombian coffee sector and the Federación Nacional de Cafeteros de Colombia, in particular. It significantly changed the Colombian coffee production system and marked the beginning of new, more complex relations among the coffee parastatal, the state, and the coffee producers. This chapter describes the events that took place in the coffee sector between 1989 and 1997 and explores the new role and position of FEDECAFE, producer responses to the crisis, as well as the apparent indifference of the Colombian state following the liberalization of the world coffee markets.

\section{Colombia and the quest for a new International Coffee Agreement}

Although the International Coffee Agreements in effect between 1962 and 1989 did not bring total stability to the Colombian coffee business, they provided price and volume guarantees to Colombian producers of the green bean. With the disappearance of these minimal assurances, coffee institutions and producers are now subject to the volatility of the world markets, which has created a whole new set of problems and issues for FEDECAFE and the coffee producers themselves.

In Chapter I, I discussed the numerous reasons for the collapse of the ICAs and some of the international implications of that collapse. It is worth describing the Colombian stance vis-a-vis the coffee agreement in 1989, as it directly affected 
FEDECAFE's policies. The Colombian authorities realized that the ICAs were far from perfect; they also were aware of the diverging perspectives among the various producer and consumer countries with regard to coffee quotas and prices. Finally, they understood that the neoliberal ideology prevailing in Washington was not favorable to the signing of a new International Coffee Agreement.

Despite these important obstacles, FEDECAFE and the Colombian government as a whole remained interested in, and committed to, signing a new International Coffee Agreement until 1993. A Special Issue of the Colombia Information Service Newsletter in 1989 states the official Colombian perspective:

The government of Colombia has repeatedly sustained that the International Coffee Agreement is key to the stability of the world coffee market and the Colombian economy. Colombia therefore continues to support the agreement and urges all producers and consumers to take an active and constructive role in the negotiations of the new agreement. ${ }^{1}$

In fact, Colombia led numerous important international efforts to bring diverging member countries back to the negotiating table. These attempts are chronicled and described in numerous and regular articles appearing in one of the country's main newspapers, $E l$ Tiempo, as are the hopes and disappointments of the Colombian leaders. ${ }^{2}$

1 "Colombia and the Coffee Agreement," Colombia Today (New York, NY), Special Issue, 1989, p. 3.

${ }^{2}$ A representative array of these articles includes the following: "Es dificil renegociacion del nuevo Pacto Cafetero," El Tiempo, September 14, 1989, p. 11C; "Aceptan prolongar el Pacto Cafetero," El Tiempo, October 3, 1989, p. 1A; "La posicion de Brasil deprime precio del cafe," El Tiempo, October 4, 1989, p. 1A; "Cumbre de OIC: sin pena ni gloria," El Tiempo, October 6, 1989, p. 1A; "Ofensiva diplomatica para restaurar pacto de cafe," El Tiempo, October 14, 1989, p. 6A; "Un nuevo pacto o retencion, discutiran paises cafeteros," El Tiempo, November 15, 1991, p. 4C; "Adios al Pacto Cafetero?," El Tiempo, February 2, 1992, p. 6C. 
February 1992 brought a shift in Colombian policy towards a new International Coffee Agreement. Although the Colombian government publicly continued to support efforts to reach a new ICA, it decided to abandon its leadership role in the endeavor for a new treaty. In fact, Colombia decided not to send representatives to the negotiation meetings held in London that month, as it felt that the various parties involved were not close enough to an agreement to warrant the presence of the Colombian delegation. ${ }^{3}$ This was a first for the country of Juan Valdez.

When it became certain in early 1993 that no new International Coffee Agreement would be signed among producers and consumers of coffee, Colombia joined with other producers in August of that year to form the Association of Coffee-Producing Countries. ${ }^{4}$ The members of this new organization agreed at first to withhold 20 per cent of their crops from the world markets in order to push coffee prices up. They succeeded in the short-term in obtaining slightly higher prices but this system was not as effective as the ICA in maintaining reasonable prices since the consumer countries of the beans were not involved.

No New International Coffee Agreement:

Does This Impact the Colombian Coffee Sector? (1989 - 1991)

The evolving Colombian stance on the International Coffee Agreement is important for two reasons. First, the country's leaders and coffee representatives initially

3 "¿Adios al Pacto Cafetero?," El Tiempo, February 2, 1992, p. 6C.

4 "Cartel Begun on Coffee," The New York Times, August 18, 1993, p. D2. 
devoted considerable effort to obtaining a new International Coffee Agreement. Second, this hope for, and pursuit of, a new international treaty had a clear impact on FEDECAFE's policies following the collapse of the accords. In particular, the original belief on the part of FEDECAFE leaders that a new agreement would be signed seems to have delayed their reaction to the agreement's collapse.

FEDECAFE was at a bit of a loss following the breakdown of the coffee agreement and the immediate decrease in world coffee prices; its policies and recommendations for the first years after 1989 were contradictory, especially considering the cyclical nature of coffee production (it takes five years for coffee trees to grow coffee). Starting in mid-1989, FEDECAFE encouraged and pushed coffee growers to produce substantially more coffee for export, the idea being for the sector as a whole to make up the price differential by exporting more bags of coffee. This policy did, indeed, result in less severe losses for the sector in 1989. Colombia exported 11.3 per cent more bags of coffee in 1989 than in 1988 and only lost 7.3 per cent of its revenues. ${ }^{5}$ These losses were lower than anticipated. FEDECAFE had foreseen that the sector would fall \$200 million short of its 1988 income and it managed to limit the damage to \$106 million less than originally forecast. It is worth noting, however, that Colombia was comparatively passive in its international coffee sales in 1989. Mexico, for example, increased its coffee sales by 190 per cent in $1989 .{ }^{6}$ This "export as much as you can"

5 "Ingresos por cafe superaron calculos," El Tiempo, January 15, 1990, p. 1A.

6 "Colombia no fue el mas agresivo," El Tiempo, January 22, 1990, p. 2 B. 
policy seemed efficient in the short-run, although it did not make up the entire difference in the national revenue.

In this first phase of the free coffee markets, FEDECAFE used some of the economic resources available in the Fondo Nacional del Café to maintain reasonable prices for the Colombian producers, at least partly because the organization thought that a new international agreement would be signed soon. In doing so, the agency endeared itself to producers but placed itself in a difficult financial situation. It had to use money that had been earmarked for other projects to make up the important price differential. Thanks to these measures, however, Colombian coffee producers were at this time spared the direct brunt of the severe drop in international coffee prices.

All of this, however, brought about another immediate and key policy change for FEDECAFE, related to its important infrastructural investment in Colombia's coffeegrowing regions throughout its existence. Up until 1989, the parastatal had contributed significantly to regional social and economic development by giving villages and towns the funds and means necessary to build much-needed roads and schools, as well as to install electricity, telephone lines, etc. In the department of Caldas alone, for example, FEDECAFE had provided electricity to 26,549 homes, built 463 aqueducts for 30,000 homes, 1400 kilometers of roads, 1382 buildings for schools and installed 1000 telephone lines. ${ }^{7}$ Because of its new difficult financial situation after 1989, however, the agency became unable to render the assistance to which local governments had grown accustomed. Between 1989 and 1992, the participation of the Coffee Federation and its

7 "Quien cuidara del Eje Cafetero," El Tiempo, October 24, 1992, p. 7 B. 
committees in infrastructural projects decreased by 50 per cent, leaving the coffee regions to fend for themselves for the first time. ${ }^{8}$ The Federation still put forth ideas for projects and encouraged their completion, but it could not carry the financial load as it had in the past.

Throughout this first period following the collapse of the ICA, the Federacion Nacional de Cafeteros was quite visible and some of its leaders were seen negotiating and working towards a new International Coffee Agreement, while others were seen touring the coffee region, giving practical advice and listening to producers. The parastatal provided technical and empirical know-how through its Extension Service and its publications for coffee producers. El Caficultor, a monthly publication written specifically for coffee growers, was filled during this time with useful tips and praise for Colombian coffee growers. ${ }^{9}$ The Federation and all of its local representatives worked hard to project the image of an organization that is present in the coffee regions, helping the peasants through this difficult period and listening to their needs.

The coffee producers did need the technical assistance of FEDECAFE extension agents to fight la broca -- "a black insect about the size of a needle head that causes great damage as it perforates the fruit" of the coffee trees. ${ }^{10}$ It first appeared on Colombian

${ }^{8}$ Maria Errazuriz, "La Crisis de la Caficultura y Su Impacto Social," Analisis Politico, 20 (Sep/Dec 1993), pp. 64-70, p. 68.

9 "Nuestro Objetivo: el hombre cafetero y su familia," El Caficultor, March 1991, p. 4; "Atrevase a ser empresario," El Caficultor, June 1991, p. 8; "Cuatro consejos para ser mas productivos," El Caficultor, December 1991, p. $14 .$.

10 "Seis mil hectareas con broca," El Tiempo, June 8, 1990, p. 1B. 
coffee farms in September 1988 but did not become widespread until early in 1991; it affected 2500 hectares in 1990 and 17,000 in November 1991. ${ }^{11}$ Coffee farmers were encouraged to plant a new strand of coffee trees resistant to this insect. Special funds were made available for producers fighting the broca, which actually provided muchneeded "oxygen" to the extension service during this difficult time. ${ }^{12}$ Despite FEDECAFE's technical assistance, the insect continued to spread throughout the Colombian coffee regions.

In regions where the broca was affecting almost 100 per cent of the coffee plants, growers were also encouraged to diversify their crops. In the department of Risaralda, for example, a Korean-Colombian venture started producing silk instead of coffee. ${ }^{13}$ The Colombian climate is apparently particularly suited for the production of silk, which fetches a much higher price on the international market and is reportedly immune to disease.

Between 1989 and 1991, the financial situation of the Fondo Nacional del Café changed drastically for the worse. In 1989 , the Fondo's capital was $\$ 1.5$ billion; by 1991 , it had decreased to $\$ 390$ million. ${ }^{14}$ This rapid drop is the result of the Fondo's

${ }^{11}$ Gilberto Arango Londoño, Por Los Senderos del Café: De La Gran Bonanza a la Peor Crisis: 1975-1993 (Bogotá, Colombia: Ediciones Fondo Cultural Cafetero, 1994), p. 293.

${ }^{12}$ Interview with Director of Centro Nacional de Investigaciones del Café, Chinchina, Colombia, March 1997.

${ }^{13}$ Martin Alonso Parra, "Risaralda: del café a la seda," El Tiempo, February 10, 1990, p. $6 \mathrm{~B}$.

14 Arango, p. 295. 
expenditures to maintain the domestic coffee price at a reasonable level and to help the coffee producers rejuvenate their bushes and fight the broca. The lower level of the Fondo's capital would bring about some changes in FEDECAFE's crisis management as well.

FEDECAFE as an organization did not escape the tightening of the Fondo's financial means. In June 1990, there was a call for the Federation to reduce its expenses and staff. ${ }^{15}$ The parastatal had been increasing its size and its spending steadily in the previous years and now needed to scale itself back. The Federation reduced its staff throughout the country by about 10 per cent by letting go 309 employees over the course of two years. ${ }^{16}$ Its total number of employees was 3549 in 1991.

With the Fondo Nacional del Café in real financial jeopardy and the Federation now unable to provide significant basic assistance, one of the key questions for coffee producers, FEDECAFE leaders, and regional officials was: who or what was going to replace the Federation's contributions in the coffee-producing areas? The Federation had taken on the role and position of the state itself in these regions of the Colombian countryside; ${ }^{17}$ it was unclear what entity would fill that void in the future. ${ }^{18}$ The regions hoped that the national government would pick up where FEDECAFE left off but there had been no indication of that by 1991 .

15 "Federación de Cafeteros debe reducir gastos," El Tiempo, June 8, 1990, p. 1 B.

16 "Bonos para financiar faltante de cafeteros," El Tiempo, October 23, 1991, p. 8A.

${ }^{17}$ Interview with Dr. Echeverri, Comité Nacional de Cafeteros de Colombia, Bogotá, Colombia, June 201997.

18 "Quien cuidara del Eje Cafetero," El Tiempo, October 24, 1992, p. 7B. 
A study produced by CRECE analyzed on a national scale the allocation of state money for regional projects. No relationship was noted between the contribution of a given region to the GNP and the state's assistance; there was also no relation between the living conditions in a region and the investment of the state. ${ }^{19}$ It is thus not expected that the state will invest much in the Colombian coffee region, which has supplied the country with considerable economic growth but also needs much assistance to improve its living conditions.

In my opinion, this very change in the situation and function of the Federation, in other words its inability to provide the level of infrastructure and services as it had in the past, prompts questions about the organization's raison d'être. FEDECAFE, itself, was obviously concerned about its existence and its future. It needed to ensure that it would just not disappear from the Colombian political and economic landscape altogether. The Constituent Assembly of 1991, which rewrote the Colombian constitution, provided the perfect avenue for FEDECAFE to preserve its existence. ${ }^{20}$ Thanks to the interventions of Alfonso Palacio Rudas, participant in the Assembly, the parafiscal status of FEDECAFE was formally legalized in the new constitution, thus protecting the organization's indefinite survival.

Further weakening the position of FEDECAFE and the Colombian coffee sector is the transformation of the national government's perspective on the role of coffee within

19 "Quien cuidara del Eje Cafetero," p. 5D.

${ }^{20}$ Maria Escobar Tello, Fedecafe y Estado: Historia, Coyuntura, y Transformacion de Una Relacion Paraestatal (Universidad de los Andes thesis, 1995), p. 89-90. 
the changing national political economy. Rudolf Hommes, Minister of Finance, describes the evolving position of coffee quite well: "The importance of coffee production does not stem, as it did in previous decades, from its contribution to the export revenues of the country but rather from its role as the generator of wealth and employment for thousands of Colombian families and its contribution to the social stability of a large part of the country." 21 The coffee sector is thus no longer the main and primary source of government revenues. According to Errazuriz, coffee exports decreased from 80 per cent of the value of Colombian exports (between 1950 and 1980) to just 17 per cent (in 1992). ${ }^{22}$ The economy was no longer entirely dependent on production of the one commodity as other sectors had grown substantially. The pumping of oil on Colombian territory was, for example, one of the state's preferred priorities and strategies. ${ }^{23}$ Coffee production, however, does remain a significant part of the Colombian economy because it employs approximately 350,000 Colombian families and, as a productive activity, it occupies a substantial part of the Colombian national territory which could not adequately be used for other fruitful pursuits.

The coffee sector's new, more limited, role in the national economy has had an important impact on the government's willingness and interest in negotiating with FEDECAFE and coffee producers on numerous policy issues throughout the period under

21 "Discurso del Ministro de Hacienda, Rudolf Hommes, ante el XLIV Congreso Cafetero," Revista Cafetera, 199 (July-December 1989), p. 42.

${ }^{22}$ Errazuriz, p. 64.

23 "Café: conciencia de crisis," El Tiempo, March 3, 1992, p. 4A. 
discussion. According to Escobar, the government was more interested in pursuing its new neoliberal economic model than in resolving the coffee region's crisis. ${ }^{24}$ It did not hesitate to take actions which would actually directly and negatively impact coffee producers. The revaluation of the peso in late 1990 is an example of this. The state's goals will become clearer in the next section of this chapter.

It also became unmistakable during this time that the domestic consumption of coffee in Colombia had dropped significantly between 1981 and $1991 .^{25}$ This phenomenon is blamed on increased consumption of sodas, juice, yogurt drinks and the fact that Colombians have been accused of not knowing how to prepare good coffee. While the Colombian population has grown 22 per cent, total coffee consumption went down 15 per cent. In 1981, each Colombian consumed 3.2 kilograms of coffee per year while in 1991, this decreased to 2.3 per year. This decline in national consumption was just yet another negative factor with which the Colombian coffee sector had to contend.

\section{No New International Coffee Agreement:}

The Colombian Coffee Sector Feels Serious Impact At Various Levels

$$
\underline{(1992-1993)}
$$

The subsequent two years mark an important chapter in the coffee crisis in Colombia for several reasons. First, it is during this time that the impact of the ICA's disintegration began to be felt at all levels of the coffee sector, from the small peasants to

\footnotetext{
${ }^{24}$ Escobar, p. 84.

25 "Café:se enfria el consumo," El Tiempo, November 25, 1991, p. 1 B.
} 
the large ones, from the Federación to the national government. Second, the policies of the various administrative entities involved were put into effect at this point and in some instances had to be changed. Opinions regarding the crisis and the responsibilities involved were also formed in these years and would influence the future of coffee in its Colombian context.

Because its short-term plans for coffee production did not positively impact the sector in crisis, the Federation had to modify its long-term approach to the coffee sector quite radically. The parastatal began pushing for an important decrease in coffee production for two reasons. ${ }^{26}$ It had become clear that no new International Coffee Agreement would be signed. This implied that the quota system would be dropped and that prices would not increase substantially for the foreseeable future. In addition, the Colombian coffee crop had reached a dangerously high level. In 1991, the country produced almost 18 million bags of coffee, 7 million more than before the collapse of the ICA. ${ }^{27}$ This increase in production did not improve the economic situation of the producers and the Fondo; on the contrary, it worsened it.

FEDECAFE's new agenda for the coffee sector included a number of different policy objectives, including some that could have never been imagined in Colombia previously. These revised goals included: the eradication of coffee trees, the diversification of crops, investment in domestic roasting of coffee, research aimed at reducing production costs, the creation of conditions for gourmet coffee production, a

\footnotetext{
${ }^{26}$ Escobar, p. 88 .

${ }^{27}$ Arango, p. 298.
} 
decrease in subsidies and credits for the coffee regions and the sales of financial institutions belonging to the parastatal. ${ }^{28}$ All of these measures were aimed to help the Fondo through this crisis.

For the first time in Colombian history, coffee producers would be paid to eliminate coffee trees and plant other products. FEDECAFE's target was to eliminate coffee production on 100,000 hectares in good condition..$^{29}$ Farmers would receive the equivalent of 1,000 dollars for each hectare of eradicated coffee trees. In addition, the plan foresaw the additional elimination of coffee plantations where the broca was particularly pervasive. ${ }^{30}$

The diversification of crops led different coffee departments in different directions. While the department of Risaralda was considering silk production, the department of Caldas contemplated returning to the trade that had historically existed in the region before coffee, cattle. ${ }^{31}$ It was viewed as a quick and financially beneficial alternative to coffee production in these difficult times.

FEDECAFE was also behind a serious effort to undertake the Colombian roasting of Colombian coffee since it is at that step of the production chain that the most money is
${ }^{28}$ Escobar, p. 84.
${ }^{29}$ Arango, p. 300.
30 "Sacrificio cafetero," El Caficultor, June 1992, p.1 and p. 4.
31 "El nuevo Viejo Caldas: una idea café con leche," El Tiempo, October 26, 1992, p. $8 B$. 
made in the coffee business. ${ }^{32}$ Germany, Finland, Italy, Yugoslavia all put forth plans to import Colombian roasted coffee. Although this is in theory a wonderful idea, it presents a problem peculiar to Colombia. As the producer of the world's best coffee, the country does not have low quality Robusta coffee to mix in with its beans. The processed coffee is thus 100 per cent Colombian Arabica coffee and is more expensive than the coffee roasted by multinational companies, which generally mix at least two different kinds of coffee beans at the roasting stage.

Because of its increasingly precarious financial situation, the Fondo Nacional del Café had to scale back a number of its activities. ${ }^{33}$ In particular, it had to reduce its contributions to technical assistance and community aid programs to alleviate its growing economic burdens. The sale of financial entities belonging to FEDECAFE was also considered as a way of recapitalizing the Fondo Nacional del Café. It seemed like an interesting option on the short-term as it would put money back into the Fondo.

Colombian coffee producers began to feel the radical change in world coffee markets approximately two years after the fact. Until then, FEDECAFE and the Fondo Nacional del Café had kept the domestic coffee price relatively high. It was in October 1991 that the growers began to see the effects of fluctuating world coffee markets. ${ }^{34}$ In March 1991, they were given an 11 per cent raise in coffee prices, which was to contribute 5D.

32 "Colombia se alista para exportar café procesado," El Tiempo, October 16, 1992, p.

${ }^{33}$ Arango, p. 300.

34 "Llego la mala hora: cafeteros," El Tiempo, October 8, 1991, p. 6A. 
to a promised total increase of 22 per cent in that year. However, in October, the government did not allow for the additional price hike to go into effect as it viewed this step as dangerous for the future existence of the Fondo Nacional del Café. Therefore, over the course of 1991 the producer price of coffee only rose 17 per cent while the rate of inflation went up 27 per cent. The coffee producers were obviously quite unhappy about this pricing scheme.

In November 1991 and February 1992, the Comité Nacional de Cafeteros (National Committee of Colombian Coffee Producers which, as discussed in the previous chapter, heads FEDECAFE but is made up of a slight majority of government officials) adopted even tougher measures for coffee producers. In addition to not getting their entire scheduled increase, ten per cent of the payments they would get for their coffee bags would be distributed in the form of Titulos de Ahorros Cafeteros (Coffee Savings Certificates, TAC) starting in November $1991 .{ }^{35}$ These TACs could be cashed 36 months later and would earn an annual interest rate of 25.44 per cent (less than the Colombian annual inflation rate). Thus, farmers would get 90,000 pesos in cash and 10,000 pesos in TACs per bag of coffee, which was supposedly done in an effort to maintain the cash flow and existence of the Fondo. In February 1992, the Comité Nacional de Cafeteros decided to decrease the domestic price of coffee for 1992 to 95,000 pesos per 125 kilos of coffee. In addition, the TACs remained in place.

35 "Acuerdo cafetero para afrontar la crisis del fondo," El Tiempo, November 8, 1991, p. 1 A. 
The farmers therefore first felt their economic losses during the course of 1992 when the value of their crop and their actual income decreased. However, the effects of the continuing coffee crisis and the changes in the Federation's policies would have much deeper social implications for all Colombian coffee-producing areas. First and foremost, 42,000 hectares of coffee were eliminated following FEDECAFE's policy change; 73 per cent of these eradications were located in the Western part of the country. Coffee production in this area would thus drop significantly. In addition, 15,000 jobs or 4 million work days were lost with the decline in coffee production and the subsequent reduction in pay. Coffee cultivation and culture also changed as the coffee growers sought to save money and severely cut back on the fertilization of their coffee plants and the renovations of their plantations. The consumption of coffee-producing families also went down significantly. ${ }^{36}$

Absolute poverty, delinquency, and subversion could now be found in the region. ${ }^{37}$ In the words of Maldonado, "thefts on the farms, robberies in the villages, assaults on banks are only, according to the experts, the first symptoms of the serious social situation which is approaching." ${ }^{138}$

Maldonado accurately noted class distinctions in the impact of the crisis on coffee producers. He predicted that medium producers would slowly disappear as they would

${ }^{36}$ Errazuriz, p. 68.

${ }^{37}$ Fernando Maldonado Delgado, "Educacion y cultura cafetera en Risaralda: Cronica del desarraigo," Revistas de Ciencias Humanas, Universidad Tecnologica de Pereira, 4, 11(March 1997), pp. 52-58 and "El Ultimo Sorbo", Semana, August 25, 1992, pp. 54-55.

38 "El ultimo sorbo," p. 54. 
not be able to survive the price/cost of production ratio for coffee and, instead, would move on to the production of other crops with less available technology and research and without adequate market structures. The large coffee producers were not as deeply affected by the coffee crisis as they could run their plantation like a business and explore other agricultural options without much cost to them. The future of Colombian coffee production, however, rested and still rests on the small producers who represent 80 per cent of all producers. They barely survived this tumultuous period with their manual labor and that of their families. The work of migrant coffee pickers and the day workers disappeared in the new coffee scheme causing many of the problems across the region.

Throughout the period under study in this chapter, the Federation made a point of regularly reminding Colombian coffee producers that they were comparatively better off than producers in other countries. For example, Colombian coffee producers were earning approximately 35 per cent more than their Mexican and Salvadoran counterparts. ${ }^{39}$ These comments were made in an attempt to appease Colombian farmers but did not particularly help FEDECAFE's cause as most Colombian producers were not interested in the plight of foreign producers but rather in the serious changes in their own situation.

The coffee producers throughout the Colombian coffee regions began to express bitter feelings of abandonment by the state. ${ }^{40}$ They felt as if the state had forgotten about them despite their increasingly difficult circumstances. The producers were quite angry

${ }^{39}$ Arango, p. 299.

${ }^{40}$ Carlos Alberto Galvis, "Quindio: un polvorin en potencia," El Tiempo, March 23, 1993, p. 5E. 
about the decisions made by the Comité Nacional de Cafeteros with regard to domestic prices. ${ }^{41}$ "The producers feel that the state has done nothing to mitigate the social dimension of the crisis, namely unemployment, insecurity and misery."12

Starting in 1992, the producers began to blame the Federación as well as the government for their dire situation, ${ }^{43}$ which prompted a variety of debates held in the Colombian Senate with regard to the role of the Federación Nacional de Cafeteros and the Fondo Nacional del Café in the coffee crisis. In turn, Senators defended the Federation and accused it of terrible mismanagement. The debates did not produce any real results regarding assistance to coffee producers or the status of FEDECAFE.

The apparent lack of interest on behalf of the state and the difficult position of the coffee parastatal increased the feelings of desertion of the coffee producers. In 1992, some of them became more active and vocal about their plight, and they gathered in groups and created small organizations to represent them and voice their concerns. Marches and strikes began to be held in protest of the government and FEDECAFE's response to the sectorial crisis.

Small, independent groups emanating from various parts of the coffee region included: Asociacion de Productores de Café (Association of Coffee Producers), Aprocafé, Cafeteros en Alerta (Coffee Growers On the Alert), and Union Cafetera

41 "Desconcierto en zonas productoras," El Tiempo, February 13, 1992, p. 3A. ${ }^{42}$ Galvis, p. 5E.

43 "Culpan a la Federacion y al gobierno por crisis cafetera," El Tiempo, February 13, 1992, p. 12B. 
Colombiana (Colombian Coffee Union). These diverse groups met during 1992 and together formed the larger Unidad Cafetera Colombiana (Colombian Coffee Union) to confront as one the government and FEDECAFE.

The national coordinator of the Unidad Cafetera Colombiana, Jorge Robledo, laid out some of the group's concerns and beliefs. ${ }^{44}$ Their protest was mostly the result of government price policies and they understood quite clearly that coffee producers were better off during the years of the ICA. For them, "if one thing has become crystal clear in this stage of the so-called free market, it is definitely that the theory of the free enterprise, of free competition belongs more to the realm of science fiction than that of economic science." 45 The group saw that four or five large multinational corporations controled the prices at every stage of coffee production and consumption and that the corporate entities are the only real beneficiaries. They also did not view the Colombian processing of coffee as a viable option for two reasons. The international corporations in the coffee business regulated the markets exclusively so there would not be a real outlet for Colombian roasted coffee. In addition, the building of factories in Colombia belonging to the large roasters was not an acceptable idea as it would imply the use and abuse of domestic labor.

The group believed there was a need for a stronger state in Colombia which could stand up to these multinational companies and negotiate on behalf of the producers. The government needed to be fair and help the coffee producers in times of need in the same

${ }^{44}$ The next three paragraphs summarize the ideas of the group laid out in "El café: otra victima de la apertura," Deslinde, 12 (1992), pp. 23-34 based on an interview with Jorge Robledo.

${ }^{45}$ Deslinde, p. 26 
way that the latter helped the country during bonanzas. The government has also made economic decisions for the economy as a whole which have directly and additionally hurt coffee producers. The revaluation of the Colombian peso, for example, cost coffee producers 115 million pesos in 1991.

The movement had specific problems with some of FEDECAFE's actions during the crisis and it held the parastatal responsible for the use of Fondo funds by the state during the bonanzas and its inability to get the state to help the peasants in their time of dire need. It also found the Federation's willingness to sell some of its financial institutions such as Banco Cafetero reprehensible considering the impact that this would have on the already difficult economic situation of coffee producers. The group recognized the difficult organizational obstacles faced by the Federation given its financial and political ties to the state; it considered the Federation a state agency. The situation of coffee producers would be worse without the existence of FEDECAFE; however, its position could be improved. The Federation and its structure were deemed antidemocratic; it had to be opened at all levels so as not to hurt producers and should not be influenced in the end only by the opinions of the country's president.

What was FEDECAFE's response to the verbal attacks by peasants and new organizations? The combination of the discontent among coffee growers and the attitude of the government toward the coffee sector has placed FEDERACAFE in a quite uncomfortable and difficult position. Its leaders had to be particularly careful in their statements. They used several arguments against the social movements emerging among growers. The Federation depicted these popular groups as more than simply peasant 
organizations seeking justice and benefits for peasants; it claimed regularly that these associations were infiltrated by guerrillas and were thus not trustworthy. FEDECAFE, however, did not offer any evidence of this claim. The parastatal defended its particular position in the Colombian coffee sector by repeating that its long-term work on behalf of the coffee producers and its closeness to the state actually placed it in the best position to represent the peasants and obtain concessions for them.

The agency was also defending itself against the state. Some bitter remarks were also exchanged between FEDECAFE and state leaders. In particular, Jorge Cardenas Gutierrez, the General Manager of FEDECAFE, did not mince his words in stating: "in 1986 the FNC generated a surplus that represented 3 percentage points of the GNP; at that moment, public finances of the country received generous assistance from the coffee sector. I regret to have to inform you that in this crisis there has been no equivalent reciprocity." ${ }^{46}$ The parastatal was thus quite threatened by the developments but it attempted to retain its important role and position in the Colombian coffee sector.

In addition to defending the parastatal coffee agency, its representatives also had to speak up for the Fondo Nacional del Café against mounting international and domestic suggestions that it should be eliminated. ${ }^{47}$ Cardenas argued that the Fondo allows for the peasants to not be totally subject to the fluctuations of the world markets. These attacks came at a time when Colombian producers are getting less and less in exchange for their

${ }^{46}$ Escobar quotes Jorge Cardenas Gutierrez from El Modelo Cafetero: Palabras Ante la Comision Mixta de Café (Bogotá, Colombia; FEDECAFE, 1993).

47 "Rechazan desmonte del Fondo," El Tiempo, March 5, 1993, p. 13A. 
crops and labor. FEDECAFE had to defend the Fondo because much of its own funding was tied to the presence and existence of the Fondo.

The future position and role of the Federation were not clearcut at this stage. Aurelio Suarez Montoya argued that the organization must decide where its loyalties lie and described its predicament quite well from his perspective. He wrote: "FEDECAFE has to decide if it will let itself be taken to the slaughterhouse with its hands tied or if it will join the resistance of the producers. It is worth repeating the biblical phrase: You cannot serve two men because one will become bitter towards you and the other one will hate you." 48

\section{Unregulated World Coffee Markets:}

Moving Beyond the Immediate Economic Crisis (1994 - 1997)

In order to look beyond the immediate economic problems of the coffee sector, the government put together a Commission in 1993 which was to study the state of the Colombian coffee sector. This Comisión Mixta Para El Estudio del Café (Mixed Commission for the Study of Coffee) was made up of experts on Colombian coffee but did not include a single FEDECAFE leader, done to ensure a more objective perspective. The Federation's leaders were nonetheless interviewed by the Commission, which documented

\footnotetext{
${ }^{48}$ Aurelio Suárez Montoya, "Aristas de la crisis cafetera," La Tarde (Pereira), April 1, 1992, p. 4.
} 
its findings in a report published in 1994, El Negocio Cafetero Ante El Mercado Libre. ${ }^{49}$

This work does provide some new insights on the Colombian coffee trade.

The Commission noted that until it was convened, no in-depth analysis of the Colombian coffee sector's predicament had been conducted. Similarly, the Commission argued that no global strategy had been laid out or adopted to confront the changing circumstances surrounding Colombian coffee production. ${ }^{50}$ The Commission also concluded that it is urgent to modernize the coffee sector in response to the international and domestic changes. According to the Commission,

The state of prostration and general inefficiency of the Colombian coffee sector make it recommendable that producers themselves are exposed, in the most direct fashion possible, to the signals of the international market and are obliged to react to the latter using their own individual initiative, without centralized and bureaucratic mediations and paternalistic defects which today dominate the general organization and commercialization of the sector. At the level of each individual producer, the understanding of the cycles and the tendencies of the product on the international market as well as the knowledge that the best personal protection is precautionary savings and the avoidance of excess production must be developed in detail. $^{51}$

The Commission believed that the Colombian coffee sector was generally inefficient and that it needed to be reorganized to account for the sectoral transformations which had taken place. It did stop short of specifically assigning the blame for the sector's problems.

${ }^{49}$ Sergio Clavijo, Carlos Felipe Jaramillo and José Leibovich (eds.), El Negocio Cafetero Ante El Mercado Libre: Informe de la Comisión Mixta del Café (Bogotá, Colombia: TM Editores, 1994).

${ }^{50}$ Clavijo, Jaramillo, and Leibovich, p. 60.

${ }^{51}$ Clavijo, Jaramillo and Leibovich, p. 122. 
According to the Commission, the fact that coffee growers had not been directly exposed to market fluctuations actually encouraged them to pursue their inefficient production practices. The producers were described as out of touch with the realities of the market. This could on the medium-term negatively affect Colombian coffee production as it could lead to the marginalization of Colombian coffee on the world markets. ${ }^{52}$ It was the Commission's belief that if the producers were unprotected from the market shifts, a number of them who produce coffee in marginal areas would decide on their own to exit coffee production. ${ }^{53}$

The Commission suggested that private exporters be given an increasingly more important role in the financial aspects of the coffee trade. ${ }^{54}$ This would allow for FEDECAFE to reduce its financial responsibilities to the coffee sector. In addition, the Commission stated its position on the industrialization of the coffee sector very clearly; it did not view efforts to roast Colombian coffee in Colombia as a positive step primarily because of the international constraints that would be placed on the roasted coffee. ${ }^{55}$ The rules in place in foreign markets with regard to the roasted product and the impressive presence of multinational roasters would make it very difficult for the Colombian sector to sell large amounts of processed coffee and profit significantly from this enterprise.

\footnotetext{
${ }^{52}$ Clavijo, Jaramillo, Leibovich, p. 122.

${ }^{53}$ Clavijo, Jaramillo, and Leibovich, p. 122.

${ }^{54}$ Clavijo, Jaramillo, and Leibovich, p. 68.

${ }^{55}$ Clavijo, Jaramillo, and Leibovich, p. 47.
} 
In my opinion, the report highlights the distance that the state has placed between itself and FEDECAFE and the coffee sector in general. In the past, a document published by a government commission could not have been so critical of the crop that sustained the Colombian economy for so long. However, the dissociation felt throughout the account still does not allow the Commission to call for the dismantling of the Fondo or FEDECAFE.

The leaders of FEDECAFE responded to the report indirectly at the organization's meetings in September 1994: "We express to the public our astonishment and disagreement with the recent declarations and acts of some representatives from political, public and private circles, to limit, if not to say do away with, the Federacion Nacional de Cafeteros and the Fondo Nacional del Café and the role that they play in the domestic and international commercialization of the bean." ${ }^{56}$

In an attempt to protect itself and the Fondo throughout its enduring crisis, the Federación de Cafeteros had to redefine itself and its relationship with the producers. The agency tried to move away from the government's positions and worked hard to present itself as the representative of the Colombian peasants. FEDECAFE had to move away from its previously paternalistic attitude toward the producers and look more to the farmers for their needs and interests. ${ }^{57}$ Many leaders describe their organization as having been a father to the coffee producers until the collapse of the agreements. They realized

${ }^{56}$ El Caficultor, October 1994, p. 7 (as quoted in Escobar Tello, p. 87).

${ }^{57}$ Interview of Hernan Correo, Director of the Fundacion Manuel Mejia, April 1997, Chinchina, Colombia. 
that this needed to change, but were not sure how this would come about. This would involve changing not only the parastatal's rhetoric but also the perspectives of hundreds of thousands of coffee producers vis-a-vis the parastatal agency.

Additional complications in relations among the producers, the coffee parastatal and the state originate with the new presence of guerrilla movements in the coffee regions. Since the Violencia discussed in the previous chapter, the regions had been peaceful and had not been infiltrated by guerrilla groups. Starting in 1993, the possibility of their regional penetration was mentioned but it is not until 1994 that the Federación Nacional de Cafeteros officially recognized the presence of guerrillas in the coffee region.

Guerrillas also sabotaged numerous Colombian oil installations in the mid-1990's causing a cutback in domestic petroleum production ${ }^{58}$ which, in combination with a serious Brazilian frost in 1994, allowed coffee to temporarily regain a more important position in the national economy. As a result of these events, world coffee prices went up significantly. This situation was greeted with some concern among Colombian sector leaders considering the terrible predicament of the Colombian coffee trade. They wanted to limit the mistakes in the managing of this new bonanza and not waste precious money and resources. ${ }^{59}$

The unexpected rise in international prices required serious action on the part of the state. Because Ernesto Samper Pizano had been elected President and was to take

${ }^{58}$ Economist Intelligence Unit, EIU Country Profile: Colombia, 1996-1997 (London, United Kingdom, 1997), p. 34.

59 "La virgen del Café," Semana, July 5, 1994, p. 52. 
office in August 1994, the outgoing government could not make a decision entirely on its own with regard to the appropriate course of action and purchase prices of coffee in particular. In a quite uncommon move, the two governments, the outgoing and the incoming, decided together what the best response was for the coffee sector and the national political economy. The two governments defined a new price policy for the coffee industry, adopting a variable price scheme to be in effect at least from September 1994 to March 1995 which would involve an adjustment of the price every 15 days based on international price fluctuations of the previous 60 days. $^{60}$ The breakdown of the income between the peasants and the Fondo was proportional to the price increase. The higher the world prices of coffee, the more money would be placed in the Fondo Nacional del Café.

In making this choice, the two governments considered the threat of coffee smuggling. If the price differential between the international prices and the domestic prices is too high, producers will illegally sell their crops outside official channels and obtain more money for their coffee. In an effort to avoid this, the governments wanted the domestic price to reflect the world prices more closely.

During these discussions, it was also agreed that 12 billion pesos should be spent on social expenditures in the coffee region. The departments of Cauca and Huila which had been affected by a recent earthquake would receive a significant portion of the assistance while the rest of it would be spent on diversification of coffee crops and the protection of water in the coffee regions.

60 "Administrando la riqueza," Semana, July 26, 1994, p. 60-62. 
Although the General Manager of FEDECAFE attended the policy negotiations between the two governments, the state agency had very little input in the decisions made for the coffee sector. FEDECAFE had thus lost at least part of its power with regard to coffee policies.

Although the decisions made by the two governments favored higher prices on the short-term for the Colombian coffee producers, it is obvious that, at this point in the coffee crisis, higher prices were not enough for coffee farmers. The international and producer prices remained comparatively high through the end of 1995 , but coffee producers continued to voice their concerns and hold protests, nevertheless. An important strike and march was held on July 19, 1995. "For the Unidad Cafetera, the Juan Valdezes are going on strike to because they have experienced the crisis of their economic activity, but more than that, the indifference of their governments. ${ }^{161}$ The march was a result of the collapse of the international coffee agreements, the appearance and spreading of the broca and the lack of clear-cut policies on behalf of the national governments. ${ }^{62}$

Even the President of the Colombian Congress wrote to President Samper regarding the plight of coffee producers before the strike and made the following statement: "The situation has reached the limits of tolerance, Mister President. There are new interlocutors in the coffee dialogue. The sovereign and immovable entities no longer represent the majority. Speak with those who feel the anxiety of each day."63 The protest

61 "Paro Divide A Los Cafeteros," El Tiempo, July 19, 1995, p. 1A.

62 "Paro Cafetero Con Aroma De Guerrilla," El Tiempo, July 19, 1995, p. 5B.

63 "Numerosas Organizaciones Apoyan el Paro," El Tiempo, July 18, 1995, p. 13A. 
was supported by a large number of regional civic organizations, municipal governments and church representatives.

The only entities against the strike were the Federación Nacional de Cafeteros and the national government. The Federation, however, was the only one loudly stating its disagreement with the strike and trying unsuccessfully to convince its organizers and participants to cancel the strike. Its directors made their point through editorials in national newspapers such as El Tiempo and their own publications. ${ }^{64}$ However, the arguments against the strike were not particularly convincing. The Federation wanted this to be a time of exchange and dialogue and not of marches or protests. In addition, according the parastatal, there was no guarantee as to how the strike would end given the presence of guerrilla movements in the area. The pleas of the Federation did not keep the strike from taking place, and it did so calmly and with very little violence or guerrilla activity reported.

In my opinion, this strike was a very important development in the relations between the state, FEDECAFE and coffee farmers, since it highlighted the severe lack of understanding existing among them. By being the only large entity in the coffee sector opposed to the strike, it showed how out of touch it is with the coffee farmers it claims to represent. It did not understand the dire circumstances of the Colombian farmers or their demands of FEDECAFE and the national government. Moveover, it no longer has control over their group actions. The producers are more independent from the

64 "El Paro: editorial," El Tiempo, July 19, 1995, p. 4A and "Gobierno pide no hacer paro," "No al paro cafetero," El Caficultor, July 1995, p. 2. and p. 5. 
Federation than they have ever been in the organization's history. Ironically, the Federation is partly to blame for this. It wanted to move away from its former paternalistic role to give the producers more understanding and more leeway in their economic decisions.

Colombian coffee producers have made it clear that the Federation, as it exists, currently does not represent their particular interests and they would like the Federation to go one step further. They are in favor of a more open, more participatory Federation in which the individuals it is supposed to represent have some influence in its decisions and policies. It is because they did not find the Federation open to their suggestions and solutions that they created other civic groups to speak on their behalf.

This issue takes us back to the very creation of the parastatal entity in 1927. In the previous chapter, we discussed how the Federacion was created by large coffee producers and the state. It was only after the creation of the agency that attempts were made to establish a rapport between the new entity and the majority of smaller peasants. It is true that through the coffee agency, the state was given much better access to coffee producers. However, this was mostly a one-way street. Seventy years later, it is obvious that most producers are still not directly involved in the Federation's activities and decisions. The crisis has thus brought the Federation full circle back to some of the issues that faced it upon its conception.

In response to some of the attacks made against FEDECAFE, the President of the Comité Nacional de Cafeteros admits that the Federation is not an example of perfect 
democracy but he believes that the Federation has brought some level of democracy to the coffee sector. He states:

Democracy is the system of government which aspires to the advancement of man to the fullest of his fundamental rights within a ruling social order. It is toward this objective that the association has worked, creating the cultural, economic and social conditions for the coffee producer to be a conscious actor and not a mere peon in the functioning of the association. ${ }^{65}$

The Federation is thus certainly not done fighting for its role and position in the Colombian coffee sector. Is it willing to share any of its power with the group it is supposed to represent?

International coffee prices fell again at the end of 1995 and the Association of Coffee-Producing Countries was unable to keep the prices from dropping. The year 1996 was in general not a good year for the Colombian coffee sector. During that year, although there was a 17 per cent increase in exports, Colombian dollar earnings fell by 19 per cent because the price of coffee went back down. ${ }^{66}$ "The harvest was also hit by crop plagues, heavy rain, transport problems and guerrilla attacks." ${ }^{167}$ The revaluation of the Colombian peso worked against the coffee sector and forced the export economy as a whole to lose 25 per cent of its competitivity. ${ }^{68}$

${ }^{65}$ Rodrigo Munera Zuloaga, "La Federación no es antidemocratica," Revista Cafetera de Colombia, 44, 204 (1995), pp. 59-69, p. 59.

${ }^{66}$ EIU Country Profile: Colombia, 1996-1997, p. 31.

${ }^{67}$ Economist Intelligence Unit, EIU Country Profile: Colombia, 1997-1998 (London, United Kingdom, 1998), p. 34.

${ }^{68}$ Edmer Tovar Martinez, "Le tenemos más a la revaluación que a la broca," El Tiempo, October 20, 1996, p. 4C. 
The development of coffee tourism in Colombia's coffee regions in 1996 opened up new possibilities for coffee growers. ${ }^{69}$ This tourism emphasizes the beauty of the coffee hills and offers nice lodgings to vacationers who can take advantage of a number of activities and the mostly peaceful environment of the coffee regions. The department of Quindio was one of those developing this alternative to coffee production and produced colorful pamphlets to attract interested tourists. ${ }^{70}$ This would allow for some coffee producers to move away from coffee production but remain economically active in the rural coffee region.

The year 1997 saw another significant increase in the international price of coffee. The price went up significantly during this year starting at $\$ 1.20$ at the end of 1996 and going up to $\$ 3.18$ in May 1997. Coffee prices thus continue their fluctuations impacting the producers alternatively positively and negatively.

FEDECAFE's contract with the state with regard to the Fondo Nacional del Cafe was up for renegotiation again in 1997 as it is every ten years. There was much discussion on the part of numerous groups about not renewing it. Although it did, indeed, seem that modifying the system could be a productive enterprise, too many had much to gain from the status quo. After all that transpired in the coffee sector since the collapse of the international coffee agreements, the Federation and the Fondo were maintained in

${ }^{69}$ Edmer Tovar Martinez, "Cafeteros le sacan plata al paisaje," El Tiempo, October 21, 1996, p. 1B.

${ }^{70}$ Gobernacion del Quindio, "El Quindio Es Cafe y Mucho Mas," 1995. 
existence without any radical changes. That in the final analysis is quite surprising considering the activities and actions of the producers.

\section{$\underline{\text { Conclusions }}$}

In this lengthy analysis of events in the Colombian coffee sector since 1989, I discussed FEDECAFE and state policies towards the coffee sector. I put forth the reactions of producers to the changes in the international markets and in domestic policies. The question that remains is: what has been the impact of the changing international coffee markets on the dynamics within Colombian state and society?

The decision-making power in the hands of FEDECAFE has decreased significantly since its creation in the late 1920 's. Because coffee was such a central and intricate part of Colombia's national political economy for so long, FEDECAFE had accumulated much power in its hands, which extended well beyond the coffee sector into many other realms of the Colombian economy and political sphere. The Federation which exists today has lost much of that power as a result of the collapse of the ICA and coffee's new position in the Colombian economy. ${ }^{71}$

During these years, the state distanced itself from the Federation of Coffee Growers and the coffee sector as a whole as a result of the changing position of the crop in the Colombian economy. This placed the Federation in a particularly difficult position as the latter was left defending itself vis-a-vis the state and the producers.

${ }^{71}$ Escobar, p. 92. 
Coffee growers began to voice their concerns when they felt their situations worsen. They organized and created groups to protest government and FEDECAFE policies and perspectives; they put together lists of demands and wanted to be taken into consideration in decisions affecting them.

If I return to Michael Bratton's typology of relations between peasants and the state, his third scenario is the one which best applies here. ${ }^{72}$ That scenario, as stated earlier in the theoretical chapter of this dissertation, is one in which the state disengages and society engages. I would argue that the state previously tried to engage coffee producers via the Federation of Coffee Growers. However, with the loss of economic and social power of this entity and the coffee sector as a whole, the state no longer really engages the coffee producers. It has made no specific efforts to reengage the producers through different means and has not filled the financial and social void left by FEDECAFE.

On the other hand, the producers (who I would argue had until then disengaged from the state and FEDECAFE) are now very much engaged by going down into the streets to protest their predicament and the indifference of FEDECAFE and the state. As a result, they also obtained attention from other entities such as guerrilla movements. This has not helped Colombia's overall state-society relations or its movement towards peace.

The crisis caused by the collapse of the International Coffee Agreement brought about some serious changes in the institutional landscape of the coffee region.

\footnotetext{
${ }^{72}$ Michael Bratton, "Peasant-state relations in postcolonial Africa: patterns of engagement and disengagement," in Joel S. Migdal, Atul Kohli and Vivienne Shue (eds.), State Power and Social forces: Domination and Transformation in the Third World (New York, NY: Cambridge University Press, 1994), pp. 231-254.
} 
FEDECAFE lost much of its credibility vis-a-vis producers but did manage to remain in existence. The state was not able to penetrate the region any more than it had prior to FEDECAFE. Producers were left very much on their own, searching for solutions to their daily problems and issues. Several guerrilla groups stepped into the void left by FEDECAFE and the state, to gain territory and possibly to provide some of the state-like services they are known to provide.

The Colombian coffee story is far from over. Considering the rampant nature of coca production throughout the country, the Colombian state supported by the United States and other drug war allies, may very well find itself reinvesting in coffee, Colombia's primary legal agricultural crop. ${ }^{73}$

${ }^{73}$ Karen DeYoung, "A Long Way From Coca to Coffee: U.S. Aid Tries to Get Colombian Peasant Farmers to Switch Cash Crops," The Washington Post, October 11, 2000 , p. A18. 


\section{CHAPTER VI}

\section{THE IVOIRIAN COFFEE SECTOR AND ITS PARASTATALS IN HISTORICAL PERSPECTIVE}

As in Colombia, coffee has played a historically key role in the political, economic and social development of Côte d'Ivoire. Past events in the country's coffee sector still shape the evolution of the industry and affect the experiences of the producers and the outcomes for the state structures in place.

This chapter will therefore examine the significance of the coffee sector in Ivoirian national development, as well as the historical role and position of the domestic parastatal agencies involved in coffee production and distribution. The state agency most closely associated with the Ivoirian coffee sector is The Caisse de Stabilisation et de Soutien des Prix des Produits Agricoles (Stabilization Fund for Prices of Agricultural Products, also known as the Caisse, Caistab or CSSPPA) and the historical path of this entity is one of the primary foci of this chapter. The Société d'Assistance Technique Pour La Modernisation Agricole (Agency of Technical Assistance for Agricultural Modernization, SATMACI) is another parastatal that functions within the Ivoirian coffee sector. It will be mentioned throughout the chapter but cannot be considered as central to the industry as is the Caisse. These two agencies combined carry out the functions of FEDECAFE in Colombia. I will discuss the changing responsibilities of these agencies with regard to the coffee sector as well as the position of these organizations in Ivoirian state-society relations. While the focus of this chapter will be primarily on post-independence Côte 
d'Ivoire, I will begin with a discussion of the colonial coffee economy, as it had an important impact on post-colonial economic and political developments.

The Ivoirian coffee story is in general very different from the Colombian one. While the overall comparison of the two countries under study and their parastatals will take place in Chapter VII, detailed distinctions between the two cases will be made when appropriate in this chapter and the following one.

Unlike in Colombia, where the coffee sector is considered a separate segment of the national economy, coffee production and distribution in Côte d'Ivoire cannot be separated from the overall agricultural sector quite as easily. For example, the parastatal agencies catering to coffee producers and traders also serve the cocoa farmers and trading companies. In addition, Ivoirian coffee farmers don't generally grow coffee exclusively; in most instances, they also cultivate cocoa. Thus, throughout this presentation of the coffee sector's role in the Ivoirian political and economic history, the focus will be on coffee but reference will be made to cocoa when necessary.

Why is coffee such a significant part of Côte d'Ivoire's economy? As I will discuss in this chapter, coffee has played an important role in the establishment of the Ivoirian political and economic leadership and their economic policies following the country's independence.

Coffee is also important to the health of the Ivoirian economy because of its share of the Gross National Product, the revenues it has provided to the state and the profits it yielded for specific commercial enterprises. In addition, in the 1960's, coffee represented 
65 per cent of the country's total exports. ${ }^{1}$ By the early 1990's, agriculture as a whole provided 35 per cent of the Gross National Product, 80 per cent of export revenues and 60 per cent of Ivoirian employment. ${ }^{2}$

It is, however, also an essential component of the Ivoirian economic picture because it is closely tied to many other segments of the national economy. Coffee production has created demand for numerous consumer products on the part of coffee farmers, such as shoes, cloth, cooking-ware, bricks, cement, bicycles, cigarettes, beer and soft drinks. ${ }^{3}$ A viable national transportation network and thousands of jobs are also results of the coffee and cocoa economy. These various by-products of the Ivoirian coffee and cocoa exports, however, do fluctuate with the coffee crops and prices; they are positively and negatively affected by the ups and downs in the international coffee markets and accentuate the relationship between the coffee sector and the overall domestic economy.

\section{The Colonial Origins of Coffee and Commodity Production in Côte d'Ivoire}

The pursuit and support of commodity production by the French colonial authorities are key to the Ivoirian political economy for two reasons. First, obviously,

${ }^{1}$ Ministère de L'Information, Le Café et le Cacao Dans L'Economie Ivoirienne (Abidjan, Côte d'Ivoire, 1972), p. 5.

${ }^{2}$ Moise Koffi Koumoue, Politique Economique et Ajustement Structurel en Côte d'Ivoire (Paris: Editions L'Harmattan, 1994).

${ }^{3}$ Robert Hecht, "The Ivory Coast Economic Miracle: What Benefits for Peasant Farmers?," The Journal of Modern African Studies, 21, 1(1983), pp. 25-53, p. 30. 
coffee production enabled the colonial power to reap economic benefits from colonialism. In addition, however, the policies pursued by the French with regard to coffee and cocoa production would provide the structural basis for Côte d'Ivoire's post-colonial political and economic system.

Between 1898 and 1912, according to Bassett, the French consolidated their rule over the Ivoirian territory and began to establish the "conditions of commodity production." ${ }^{4}$ For Bassett, "the Ivoirian colonial government had three major policy objectives: (1) to generate enough internal revenues to remain financially self-sufficient from France; (2) to supply the metropole's industries with primary commodities normally imported from other countries and (3) to preserve, as far as possible, the interests of French merchants and settlers in the colony." ${ }^{5}$ To reach those goals, according to Nyong'o, the French colonial system in Côte d'Ivoire rested on three different social groups, namely the colonial administration, the traders, and, most importantly, African labor. $^{6}$

Coffee was first grown in Côte d'Ivoire at the turn of the century as an experiment in Elima. By 1905, a total of twenty-nine tons of coffee had been produced. By 1920 , however, numerous French settlers living in Côte d'Ivoire had started producing coffee

${ }^{4}$ Thomas Bassett, Food, Peasantry and The State in The Northern Ivory Coast: 18981982 (Berkeley, CA: University of California, Ph.D. dissertation, 1984), p. 44.

${ }^{5}$ Bassett, p. 48.

${ }^{6}$ Peter Anyang' Nyong'o, "The Development of Agrarian Capitalist Classes in The Ivory Coast, 1945-1975," in Paul M. Lubeck (ed.), The African Bourgeoisie: Capitalist Development in Nigeria, Kenya and the Ivory Coast (Boulder, Co: Lynne Rienner Publishers, 1987), pp. 185-245, p. 186. 
and their annual crop reached approximately 1,000 tons. During the 1920 's, Ivoirian cocoa production surpassed French cocoa consumption and this led the French colonial authorities to encourage coffee production as France was importing coffee from other parts of the world.?

Colonial coffee production was yet further encouraged following the world economic crisis of 1929. In April 1931, the Governor of the Ivory Coast announced a new development program entitled "The Intensification of Agricultural and Pastoral Production in French West Africa;" this initiative was meant to increase the production of commodities needed by France in the context of the world-wide depression, namely coffee, cocoa and rubber. The forest region in the Southern part of the territory was the area targeted for production by the governor. ${ }^{8}$ This initiative increased coffee production; it also encouraged differentiation in the economic missions of the Northern and Southern parts of the territory. The North was slowly becoming a reservoir of food crop production and labor for the intensive commodity crop expansion of the South.

The Dakar Economic Conference of 1945 which brought together the French government and its representatives throughout francophone Africa took this initiative one step further by decreeing that the Ivory Coast should specialize only in the production of

${ }^{7}$ Bonnie Campbell, "The Ivory Coast" in John Dunn (ed.) West African States: Failure and Promise (New York, NY: Cambridge University Press, 1978), pp. 66-116, p. 69.

${ }^{8}$ Bassett, p. 76. 
coffee, cocoa and rubber. ${ }^{9}$ By the end of the World War II, Ivoirian coffee production had surpassed its cocoa production.

How did the French specifically encourage coffee production throughout this period? They made land and labor abundantly available for coffee and cocoa production by the French settlers. As long as land and labor were readily accessible, coffee production could expand infinitely without the necessity of an increase in crop productivity. The colonial administration used and radically changed property right structures and labor laws as necessary over time to further its interests. Administrators went so far as to contradict their own previous policies and laws to maintain their authority with respect to property rights. In 1904, the colonial authorities decreed the French state owner of all "vacant and ownerless lands, ${ }^{10}$ which allowed them control over the virgin forests which could be deforested for export crop cultivation. They mandated that Africans register their lands to own them legally. In 1925, the issuing of deeds was deemed the only way to establish legal land ownership, while in 1935, all previous land titles and deeds were cancelled and customary rights were "enacted" as the predominant property rights structure. This gave the French authorities the leeway to reject African claims on land reserved for European settlers. In this latest decree, they also revised the meaning of "vacant and ownerless lands," to include land which had not been titled or occupied in more than ten years. These legal maneuvers thus reflected the endeavor of the

${ }^{9}$ Bassett, p. 81 .

${ }^{10}$ Nyong'o describes the successive property rights regimes enacted by the French colonial authorities, p. 189. 
French authorities to control the availability of land for the production of export crops specifically by the French settlers.

Comparatively, African labor was a much more critical issue for European coffee growers. As a result of the sparse population in the Southern portion of the territory and the significant need for laborers on coffee plantations, a forced labor system was set up by the colonial government to provide workers for the European coffee producers. Campbell describes for us quite well the evolution of this forced labor system:

When the French colonial administration first assumed control in West Africa, it instituted a system of unpaid labor services which served instead of tax collection and thus permitted public works such as the building of roads. During the period European plantation owners were able to recruit sufficient agricultural labor by making arrangements with traditional chiefs whereby the latter singled out teams of workers in return for a 'gift.' This system worked until about 1925 when increasing commercial interest on the part of the Europeans and Africans led to problems over the recruitment of labor which drew the administration closely into export crop production, resulting in an elaborated system of discriminatory privileges in favor of French planters. By 1943 African planters had been debarred from any recruited labor, which from then on was reserved exclusively for work on European plantations. In some cases Africans were even removed from their own plantations to be recruited for European enterprises. Other administrative and commercial policies worked, if not explicitly to discourage African planters, at least to privilege the Europeans. ${ }^{11}$

The issue of forced labor thus pitted the few large African coffee planters against European ones. The subsequent events helped to determine the Ivoirian path to independence. In 1944, African coffee and cocoa planters withdrew from the Syndicat Agricole de la Côte d'Ivoire (Agricultural Union of the Ivory Coast), the only existing planter organization, and created their own association, the Syndicat Agricole Africain

\footnotetext{
"Campbell, "The Ivory Coast," p. 69.
} 
(African Agricultural Union, SAA). Membership in the SAA was officially determined by land ownership. Members were supposed to own a minimum of 2 hectares of land to belong to the association. In practice, however, smaller farmers able to pay dues of 300 francs were also welcomed into the organization. ${ }^{12}$ At first, this new association simply wanted large European and African commodity producers to have equal access to the forced laborers; soon, however, the association was arguing for the abolition of forced labor altogether. ${ }^{13}$ Forced labor was abolished on what was to become Ivoirian territory in 1946.

During this time, European settlers were moving away from coffee and cocoa production and to focus on palm oil, rubber, timber and sugar. In 1942, they were responsible for 55 per cent of the territorial coffee production, but by 1947, they only accounted for ten per cent. ${ }^{14}$ But by 1952 , their production share had gone down to 6 per cent. The decrease in the availability of labor may have been one of the factors pushing the European settlers to produce other crops. The Africans' share of coffee production allowed for the creation of an African economic and political base and the impetus for the organization of the SAA.

The leader of the SAA, Felix Houphouet-Boigny, a wealthy Baoulé planter (who would later become President of Côte d'Ivoire), and the comité d'action politique

${ }^{12}$ Nyong'o, p. 207.

${ }^{13}$ Campbell, "The Ivory Coast," p. 70.

${ }^{14}$ Bonnie Campbell, "The State and Capitalist Development in the Ivory Coast" in Paul M. Lubeck (ed.) The African Bourgeoisie: Capitalist Development in Nigeria, Kenya, and the Ivory Coast (Boulder, CO: Lynne Rienner Publishers, 1987), pp. 281-303, p. 283. 
(Committee for Political Action) of the SAA soon founded the Parti Démocratique de la

Côte d'Ivoire (Democratic Party of Côte d'Ivoire), a branch of the Rassemblement

Démocratique Africain (Democratic African Assembly, RDA). One-third of the members of the Party were members of the SAA. In 1946, Houphouet-Boigny was elected Deputy in the French National Assembly, further strengthening his personal and political ties to France.

During this period leading up to Ivoirian independence in 1960, the views of the French colonial authorities and the rising Ivoirian elites on the economic future of Côte d'Ivoire began to converge. ${ }^{15}$ The small ascending group of Ivoirian leaders owed its economic and political position in large part to the export crop system set up by the French and they were therefore interested in structures and policies favoring continued national agricultural growth. Some, such as Houphouet-Boigny for a time, even favored the Ivoirian territory remaining part of France while the country developed. ${ }^{16}$ However, when Mali and Madagascar became independent and still maintained very strong ties to France, the Ivoirian elites chose to do the same.

Boone writes that "at the time of independence, the postcolonial regime inherited the commanding heights of an economy in full expansionary drive, propelled from below

${ }^{15}$ Jean-Francois Médard, "The Historical Trajectories of the Ivoirian and Kenyan States," in James Manor (ed.) Rethinking Third World Politics (New York, NY: Longman, 1991), pp. 185-211, p. 190.

${ }^{16}$ Richard Lucier, The International Political Economy of Coffee: From Juan Valdez to Yank's Diner (New York, NY: Praeger Publishers, 1988), pp. 254-255. 
by the spread of small holder coffee and cocoa production." ${ }^{17}$ The economic interests of the new ruling class made up of a few large landowners producing coffee and cocoa would thus be in the pursuit and maintenance of the status quo. It was to their advantage to maintain the impressive growth of the Ivoirian economy at that time. This choice on the part of the new Ivoirian elites is important because it indicates that these Ivoirians were not puppets in the hands of the French; ${ }^{18}$ they truly were pursuing their own economic agenda.

At a different level, the small farmers that composed the majority of the Ivoirian population were not directly involved in the process of decolonization. Ivoirian independence came about quite peacefully, with no rural uprising on the part of the people, no general fighting for independence as was the case for some former French colonies like Algeria. A smooth transition to independence was undoubtedly very positive for the continued prosperity of the Ivoirian economy; it did not, however, bring the new Ivoirian citizens together in a nationalistic movement or make them loyal to the new state.

Following independence, Côte d'Ivoire would be ruled by the PDCI but would remain closely tied to France by several political and economic links. The French were to maintain a military presence on Ivoirian territory; moreover, an important number of key positions in Houphouet-Boigny's cabinet were to be held by French citizens. In addition, Côte d'Ivoire became a member of the West African Monetary Union. This union was

${ }^{17}$ Catherine Boone, "The Social Origins of Ivoirian Exceptionalism: Rural Society and State Formation," Comparative Politics, July 1995, pp. 445-463, p. 449.

${ }^{18}$ Médard, "The Historical Trajectories of The Ivoirian and Kenyan States," p. 190. 
and still is made up of francophone West African countries which use the CFA franc (Communauté Financière d'Afrique, Financial Community of Africa) as their currency. The value of this currency is directly tied to the French Franc and allows the African states to take advantage of the comparative strength of the French currency. Fifty CFA Francs were worth one French franc and this value did not change from 1948 until 1994. This course would not only ensure a continuation of the colonial economic policies, it would also ensure an important role for foreigners and international capital in Ivoirian agricultural and economic development.

In addition, the policy choices made by the French colonial authorities and the new Ivoirian elites had a definite impact on future Ivoirian state-society relations. In particular, the displacement of groups of individuals (forced or for economic reasons) to the Southern coffee and cocoa region destroyed communities in the Northern part of the country and brought together diverse ethnic groups in the South. As a result, there were no particularly strong ethnic communities throughout the territory. Nor were clans and kinship an important factor in the creation and building of Côte d'Ivoire. In addition, the previously mentioned lack of connection between the producers and the young state left a void in the nation's social fabric. According to Crook, the political and economic alliances of the Ivoirian elites with the French only deepened "the general underdevelopment of local communities and the weak constitution of civil society in Côte d'Ivoire." ${ }^{19}$ A key question for this study is whether or not any organization, state or societal, has worked to

${ }^{19}$ Crook, "State, Society and Political Institutions in Côte d'Ivoire and Ghana," p. 221. 
fill the void existing in Ivoirian state-society relations. What exactly is the role of the Ivoirian coffee parastatals?

\section{The Creation of The Ivoirian Coffee Parastatals}

Two parastatal agencies were created by the Ivoirian state, or the French colonial administration before it, to structure the export crop sector and ensure its continued contribution to the national economy. Unlike in the case of FEDECAFE in Colombia, there was no direct societal involvement in the formation of the parastatal entities under study. The two entities were created by the state leaders to fulfill specific functions in the export crop sector. The first and main institution put in place to control the pricing and marketing of coffee and cocoa was the Caisse de Stabilisation. The other parastatal worthy of discussion is the SATMACI, which was supposed to improve the productivity of coffee and cocoa farming throughout the country.

These two parastatal organizations had a predecessor in the Sociétés indigènes de prévoyance (Indigenous Provident Societies, SIP) which were founded throughout francophone West Africa in 1909. According to Nyong'o, "the SIPs were founded...to train, provide credit to, and equip native labor to produce for the metropolitan market."20 They really only began to operate on Ivoirian territory in 1931. Although they were designed to assist African farmers, they "ended up as mechanisms for primitive accumulation by the colonial administrative officers and the African presidents of the

${ }^{20}$ Nyong'o, p. 195. 
SIPs."21 Farmers were thus not interested in participating in the work of these organizations. As a result, following the Second World War, it was clear that the SIPs were not reliable associations to move Ivoirian export crop production forward. Other state structures needed to be envisioned and created.

The Caisse was first created in 1955 by the French colonial authorities in their attempt to structure, and ensure revenues from, the Ivoirian coffee sector (Cocoa was added to the Caisse's responsibilities in 1956.) The French did this following a terrible crop year in which they had to hold back producer revenues to ensure the profits of private traders. The Caisse was created at the same time as the French Fonds National de Régularistation des Produits Outre-Mer (National Fund for the Regularization of Overseas Products) which was to subsidize peasant producers, private trading interests and local colonial authorities when necessary. According to Campbell, this pattern of French subsidization "was to serve as an important precedent for the post-independence period."122

Starting at independence, the Caisse controlled the coffee sector throughout the national territory. Its overall functions were the following: "to authorize and control the sales of exporters abroad; to sell some coffee directly; to control the quality of the product at the time of purchase and export; to fix the guaranteed prices and schedules; to manage

${ }^{21}$ Nyong'o, p. 195.

${ }^{22}$ Campbell, "The Ivory Coast," p. 77. 
the mechanism and the funds for stabilization; and to control access to production and determine the export quotas." ${ }^{23}$ Its involvement in the coffee sector is thus quite deep.

At the national level, it thus sets the all-important producer price for coffee and cocoa and licenses a group of 30 to 40 French, Lebanese and Ivoirian exporters. At the local level, the Caisse licenses traders and their sub-contractors. It supervises the marketing chain of the crops from their purchase to the port. The chain starts with the producer selling his crop to a trader who comes to his farm and is willing to transport his crop. The trader then sells the crop to a Caisse licensed exporter who then ships the crop out of the country.

What are the specific goals of the Caisse? According to Widner, the theoretical "aim of the Caistab was to save revenues collected from the agricultural sector in periods of high world prices in order to maintain producer prices when world prices dropped and to invest in productivity improvements, such as new varieties of seeds, irrigation systems and research." 24 There is unfortunately quite a distinction between the rhetoric of the Caisse and its actions. The protection of the Ivoirian producers was certainly one of the ideas behind the creation and maintenance of the Caisse. Unfortunately, it was not the only one and cannot be considered the most important one.

Crook describes for us how the Caisse's annual pricing system functions:

${ }^{23}$ Bertrand Laporte, Les Reformes Des Systèmes de Commercialisation et de Stabilisation des Filières Café et Cacao au Cameroun et en Côte d'Ivoire (Paris, France: Ministère de la Coopération et du Développement, 1992), p. 45.

${ }^{24}$ Jennifer A. Widner, "The Origins of Agricultural Policy in Ivory Coast 1960-1986," in The Journal of Development Studies, 29, 4 (1993), pp. 25-59, p. 38. 
The power and influence of the Caisse has been based on a system of fixed producer prices throughout the country, and an officially determined "value" for cocoa and coffee through which trader's costs plus profit margins are imputed. Exporters have to get permission to ship (quoting the price) and are obliged to reimburse the Caisse if they get more than the official price... the Caisse is also obliged to reimburse exporters up to the official price if prices fall below this mark. In return for what is a guaranteed livelihood, traders are obliged to purchase all the crop within allocated quotas, and to observe official norms on price and quality. ${ }^{25}$

What is most striking in this pricing system is the fact that private, and in most instances, foreign traders are protected no matter what the fluctuations in world prices are, whereas Ivoirian producers are only protected in a limited way. The growers are supposedly guaranteed a specific price each production year, but we will see that in crisis years, producers are not necessarily paid that promised price. Overall, however, the annual domestic price set by the Caisse has to be high enough to encourage continued crop production but low enough to allow a profit for the state and the private traders; on average, it has been less than 50 per cent of the world price. ${ }^{26}$

The Caisse was also set up to assist the country in its economic development. It appropriated part of the budget surplus to itself and contributed increasingly to the Budget Special pour l"Investissement et le Crédit (Special Budget for Investment and Credit) which financed domestic development projects of all types: cotton, rice, paper, and other products. $^{27}$

${ }^{25}$ Richard Crook, "Politics, The Cocoa Crisis, Administration in Côte d'Ivoire," The Journal of Modern African Studies, 28, 4 (1990), pp. 649-669, p. 655.

${ }^{26}$ Neil Ridler, "Comparative Advantage as a Development Model: The Ivory Coast," The Journal of Modern African Studies 23, 3 (1985), pp. 407-417, p. 408.

${ }^{27}$ Nyong'o, p. 223. 
The Ivoirian Caisse de Stabilisation differs from other African marketing boards in one significant way. "It permits the private sector to maintain its traditional role in the purchase, sale and distribution of products." 28 In other African countries with marketing boards for export crops, the boards are responsible for the purchase and sale of the products in addition to setting prices and overseeing the marketing process. This Ivoirian system, however, comparatively allows the private sector a significant profit in coffee production and distribution; it also has maintained almost intact the economic structure in place at the time of political independence. As a result, the Caisse and the traders collect the majority of the profits to be made in the Ivoirian coffee trade.

The SATMACI is the other parastatal created to operate in the Ivoirian coffee sector. It was created by the French government in 1958 to improve the productivity of Ivoirian coffee growing and impart technological knowledge to the numerous small producers. Its official objectives were the following: "(1) to participate in the agricultural education and training of the farmers; (2) to ensure the delivery of technical services and equipment to them so as to improve productivity; and (3) to participate in all studies and surveys aimed at establishing programs of development."29 The SATMACI thus worked alongside the Caisse in the coffee sector but focused on crop issues different from the ones dealt with by the Caisse. The Caisse is thus assisted in its national mission by the SATMACI and could benefit directly from increased productivity if and when the SATMACI was able to reach its goals.

\footnotetext{
${ }^{28}$ Campbell, "The Ivory Coast," p. 79.

${ }^{29}$ Nyong'o, p. 199.
} 
Although the organization was created originally to cater to all export crops, in 1970, the SATMACI's responsibilities were limited exclusively to coffee and cocoa. Extension agents were placed at the center of SATMACI's goals and operations. They visited farmers and encouraged the use of fertilizers and the planting of more productive varieties of coffee. These extension agents received their training at the Institut Francais du Café et Du Cacao (French Institute for Coffee and Cocoa).

The SATMACI also used the "block system" to disseminate its information and cultivation methods. This would entail the technical formation of small individual planters who agreed to follow SATMACI guidelines. They included the "use of selected seedlings, fertilizers, insecticide treatment, mulching, pruning, and systematic and regular weeding of fields." 30

The two state agencies operating in the Ivoirian coffee sector thus had very different goals and concerns in the same industry. They had the potential to complement each other well and provide together a wide variety of services to Ivoirian coffee producers of all sizes.

The Caisse and SATMACI were created for many of the same reasons that FEDECAFE was formed in Colombia and were meant to structure and control the coffee sector so that the coffee economy could continue to expand and provide the necessary funds for national economic and industrial development. In the next sections, we will analyze the historical evolution of the Ivoirian coffee sector and the contributions of these parastatals to the political and economic development of the newly independent country.

\footnotetext{
${ }^{30}$ Nyong'o, p. 219.
} 
As previously discussed, Ivoirian independence did not bring about immediate transformation in the country's economic structure or development thanks to the alliances existing between the French and the new Ivoirian elites. The Ivoirian authorities made few changes to the economic system set up by the French as they were reaping the benefits of a rapidly expanding economy.

Most of Côte d'Ivoire's annual coffee crop in those years was sold before it was even picked off the trees. In the Franco-Ivoirian Protocol of 1961, France agreed to purchase 100,000 tons of Ivorian coffee annually at a price set above world prices on the condition that Côte d'Ivoire limits its French coffee exports to that amount (representing more than 50 per cent of Ivoirian total production). ${ }^{31}$ France also provided preferential tariff protection for cocoa, timber, bananas, and pineapples. In return for this generous subsidy, the French maintained their exports of wheat, cloth and other goods to Côte d'Ivoire. This direct economic assistance was welcomed by the Ivoirian leaders and helped to ensure continued economic development.

The significance of coffee in Ivoirian development plans and the fluctuations of the crop's prices led the new Ivoirian leaders to join the International Coffee Agreement in 1962. France and other African countries participated in the agreement as well, with the hopes that price stability and guaranteed exports would enable coffee-producing countries to develop economically. Because Côte d'Ivoire was such a new country at that stage, it

${ }^{31}$ Lucier, p. 259. 
obviously did not have the history of participating in coffee negotiations and treaties that Colombia had.

The years from 1960 to 1978 were "fat" years for Côte d'Ivoire, during which economic growth was quite impressive. ${ }^{32}$ The numbers speak for themselves: the Gross Domestic Product increased on average each year by 7.5 per cent; the GNP per capita increased approximately 2.1 per cent annually over the period; and the volume of agricultural production went up 5 per cent per year. ${ }^{33}$ The value-added in agriculture went up 69 per cent in the 1970 's alone. ${ }^{34}$

In large part because of these impressive growth rates, Côte d'Ivoire was held up in the international community for a period during these years as a model of economic development for other developing countries to emulate. Côte d'Ivoire's model was for a time described as liberal considering the market-oriented nature of its economy. Foreign capital and foreign labor, especially those of French origin, were particularly welcomed in the country to assist with economic and industrial development at a variety of levels.

Although the facts seemed to indicate that Côte d'Ivoire was a liberal country economically, most social scientists now agree that Ivoirian economic development was not particularly liberal, considering among other things the existence, and extensive use of, parastatals by the state to reach its goals. Catherine Boone, Richard Crook, Jennifer

32 Jean-Francois Médard uses this term in "The Historical Trajectories of the Ivoirian and Kenyan States," p. 193.

${ }^{33}$ Richard Crook, "Patrimonialism, Administrative Effectiveness and Economic Development in Côte d'Ivoire," African Affairs, 88 (April 1989), pp. 205-228, p. 205.

${ }^{34}$ Ridler, p. 408. 
Widner and Dwayne Woods all argue in different ways that the Ivoirian economic order was not particularly liberal and that, on the contrary, the state had a very important role to play. It set up a system that allowed foreign workers and foreign capital to flow into the country and also used its structure to supervise and control coffee production and distribution for example.

It is difficult to discuss the Ivoirian state without describing the role that Felix Houphouet-Boigny played as President of the country throughout this entire period. In many ways, he defined and personified the Ivoirian state. ${ }^{35} \mathrm{He}$ is the central figure of both Ivoirian decolonization and Ivoirian statehood, and is seen by many Ivoirians as the father or grandfather of Côte d'Ivoire. He shaped the state itself, its structures and policies according to his interests. He surrounded himself with individuals who assisted him and agreed with him.

Houphouet-Boigny did not manage opposition well. He "generally controled political opposition through cooptation, periodic reassertion of authority over expanding and proliferating patronage networks, and tight control of the resources necessary to build a credible opposition. ${ }^{136}$ He used political violence sparingly during his reign.

Houphouet-Boigny's economic policies were very much the result of his personal interests and at first focused primarily on export agriculture. As a landowner and coffee

${ }^{35}$ For a detailed analysis of the way in which he did this, read" Jeanne Maddox Toungara, "The Apotheosis of Côte d'Ivoire's Nana Houphouet-Boigny," The Journal of Modern African Studies, 28, 1 (1990), pp. 23-54.

36 Jennifer A. Widner, "Two Leadership Styles and Patterns of Political Liberalization," African Studies Review, 37, 1 (April 1994), pp. 151-174, p. 153. 
and cocoa farmer, he was mainly interested in maintaining and increasing Côte d'Ivoire's export crop production in the early stages after independence. Widner writes:

If the chief of state himself derives private income from farming, a country is also more likely to pursue policies favourable to agriculture. This argument sheds some light on the early independence period. Not only did many key political elites farm considerable acreage, they also shared beliefs about market structure and behaviour that led them to favour high producer prices for export crops. ${ }^{37}$

Houphouet-Boigny promoted the importance of coffee and cocoa production to Ivoirians throughout the country but he was quite forceful with his government colleagues.

According to Boone, he specifically required his government officials to own and oversee coffee and cocoa plantations in their places of origin and invest in their communities. ${ }^{38}$ These actions were to prove that the leaders cared about their rural villages of origin.

In accordance also with Houphouet's interests, the state was busy organizing, maintaining and expanding state agencies to support the agricultural development of Côte d'Ivoire. The number of parastatals created by the Ivoirian state in fifteen years is impressive. "Fifteen parastatals were charged with implementing rural development programs, twelve were involved in research and training, and ten were engaged in agroindustry or provided financial services." ${ }^{39}$ In addition, the responsibilities of the Caisse were expanded beyond coffee and cocoa production to include other agricultural products, specifically cotton.

\footnotetext{
${ }^{37}$ Widner, "Agricultural Policy in Ivory Coast 1960-1986," p. 27.

${ }^{38}$ Boone, p. 453.

${ }^{39}$ Bassett, p. 193.
} 
From everything mentioned thus far, it seems as though starting at independence, the Ivoirian state controlled the production and distribution of coffee without giving producers ways to bypass the existing system or set up their own. In fact, HouphouetBoigny did provide farmers with an opportunity to organize and set up an alternative system which would allow them to participate more actively in the economic process. This possibility came in the form of the Groupements de Vocation Coopérative (Selling Cooperatives, GVCs). ${ }^{40}$ They were to be recognized as legal buying agents and could keep the profit margins that the private traders normally took for themselves; they could spend those proceeds on community projects of their choice.

Unfortunately, these organizations represent mostly a missed opportunity on the part of both the state and the producers. Between 1960 and 1980, the percentage of coffee handled by such rural organizations only increased from 10 to 20 per cent. ${ }^{41}$ Through the Caisse and the SATMACI, the state worked to control the cooperatives. ${ }^{42}$ It named the managers of the cooperatives and imposed objectives onto them. It also placed financial burdens on them. In short, although the state was searching for a way to reach the peasants, it really treated these rural cooperatives as "extensions of the parastatals." ${ }^{43}$ On the producer side, many Ivoirian farmers chose not to participate in these associations

${ }^{40}$ Boone, p. 456.

${ }^{41}$ Boone, p. 456.

${ }^{42}$ Dwayne Woods, "The Politics of Organising the Countryside: Rural Cooperatives in Côte d'Ivoire, The Journal of Modern African Studies, 37, 3 (September 1999), pp. 489506, p. 496.

${ }^{43}$ Woods, p. 496. 
as a result of state involvement and the disjointed nature of rural society. The ethnic, class and age differences in the villages did not engender cooperation within rural organizations. The failure of these cooperatives overall is just another indication of the disconnection that existed between coffee growers and the state.

Over the years, this situation only got worse as the interest of the elites in actual production decreased. The acreage belonging to the ruling elites diminished and other interests arose among them. Widner indicates that the ruling elites became more involved in companies processing the Ivoirian primary products than in the production of the commodities themselves. ${ }^{44}$ Over the long-term, it is not difficult to see how the interests of the elites changed as they moved away from their direct agricultural ties. It then became easier for them to ally themselves with the traders and the industrialists further up the production chain who benefited significantly from the Ivoirian coffee trade. This would only make state-producer relations more difficult and more removed.

In the early 1970 's, the Ivoirian economy slowed down slightly for several reasons. Land was no longer abundantly available for coffee and cocoa plantations as most of the forests had been decimated. While forests spread across 12 million acres at the country's independence, in 1975 , only 6 million acres of forest remained, ${ }^{45}$ a fact that

${ }^{44}$ Widner, "Agricultural Policy in Ivory Coast 1960-1986," p. 29.

${ }^{45}$ Eric Léonard and Jonas-Guéhi Ibo, "Appropriation et gestion de la rente forestière en Côte d'Ivoire," Politique Africaine, 53 (March 1994), pp. 25-36, p. 25. 
obviously slowed down the continued rate of deforestation but also had a direct impact on the local climate, the stability and richness of soils and the growth of plants. ${ }^{46}$

In addition, during this time, coffee productivity had not increased, in part, because of the government's ambivalent attitude toward SATMACI. Although this agency was created specifically for the purpose of increasing the output of export crop producers, this was not a priority for the Ivoirian state. Boone argues that the continued and ample availability of land and labor in the Southern part of the country allowed for increasing state revenues without "resorting to heavy-handed intervention in peasant production." ${ }^{47}$ Over the period, the parastatal had involved no more than 10 to 15 per cent of all coffee and cocoa farmers in its technical assistance programs. ${ }^{48}$ It thus was not able to keep GNP growth on the increase when land was no longer available for expansion of export crops.

Côte d'Ivoire was also somewhat affected by the economic slowdown in the Western countries. The rise in oil prices caused purchases of coffee and cocoa to decrease slightly.

However, before the Ivoirian government acted on this relative slowdown, international coffee prices shot through the roof in 1975 as a result of a frost in Brazil. This provided a four-year bonanza for the Ivoirian leaders, the state, the foreign traders and some producers. The boom basically had two immediate consequences for the

\footnotetext{
${ }^{46}$ Léonard and Ibo, p. 25.

${ }^{47}$ Boone, p. 447

${ }^{48}$ Crook, "Politics, The Cocoa Crisis, Administration in Côte d'Ivoire," p. 658.
} 
Ivoirian economy. First, export earnings increased dramatically. They doubled from 265 billion CFA francs in 1975 to 592 billion francs in $1977 .^{49}$ The trade surplus and the Caisse surplus also increased significantly. During the boom period, the Caisse provided 57 per cent of overall public investment. In 1976, it provided 78 per cent of the funds. ${ }^{50}$ Ivoirian profits from the coffee sector more than tripled over the following three years and provided the President with much leeway in his national development strategies. ${ }^{51}$

The development policies chosen by Houphouet-Boigny's governments until then had accentuated the ebbs and flows of the international commodity markets. The sizeable production of the two most important Ivoirian agricultural commodities was supposed to boost the international economic position of Côte d'Ivoire and provide it with the ability to develop itself industrially. This is illustrated quite vividly in Houphouet-Boigny's remarks:

It is often said that animal husbandry and grazing are the two breasts that have suckled France, but we think that this famous phrase can be adapted to us: agriculture and grazing are the two breasts that feed the young Republique de Côte d'Ivoire, thanks to what we will accomplish together in the northern part of our country. ${ }^{52}$

${ }^{49}$ Ridler, p. 410.

${ }^{50}$ Widner, "Agricultural Policy in Ivory Coast 1960-1986," p. 38.

${ }^{51}$ Assou Massou, "La Côte d'Ivoire: Eveil d'Un Elephant," Jeune Afrique, 1818 (1995), pp. 79-134, p. 94.

52 Widner cites this comment in "Agricutural Policy in Ivory Coast 1960-1986," p. 43. 
This strategy provided impressive prosperity to the Ivoirian economy as long as the world prices and demand for its commodities remained high. ${ }^{53}$

It is worthwhile to note the way in which the Ivoirian press reported on coffee and cocoa prices during this period of economic boom. In 1976, the article in Fraternité Matin (the main Abidjan daily which puts forth the state's agenda and official perspectives) announcing a slight increase in producer prices for both coffee and cocoa is quite revealing. ${ }^{54}$ No mention is made of the positive international context. The world setting is actually described as "extremely difficult." ${ }^{55}$ In addition, the peasants are told how to feel: "no doubt that the Ivoirian peasants will be thankful to their government and especially to the Father of the nation the President Felix Houphouet-Boigny," for their generosity. ${ }^{56}$ This quote summarizes very well how peasants and Ivoirian citizens in general were supposed to feel towards their government at this point in time: they were to be thankful for the wonderful things Houphouet-Boigny and his governments had done for the country regardless of the fact that producer prices were actually quite low. The tone of this article in particular is quite condescending, as if the producers themselves could not decide how to feel about the situation. It is yet another indication of the top-down relationship

${ }^{53}$ Harmut Schneider, Adjustment and Equity in Côte d'Ivoire (Development Centre of the Organisation for Economic Cooperation and Development, 1992), p. 13.

54 "Les campagnes 76-77 ont démarré," Fraternité Matin (Abidjan daily), October 6, 1976, p. 3.

55 "Les campagnes 76-77 ont démarré," p. 3.

56 "Les campagnes 76-77 ont démarré," p. 3. 
between the state and the majority of producers, even during Côte d'Ivoire's economic boom.

\section{Coffee and Côte d'Ivoire from 1978 to the end of The International Coffee Agreement}

The unusually elevated coffee prices and exports would only last four years. Their drop in the late 1970's to pre-1975 levels marked the beginning of more difficult times for the Ivoirian economy in general and the export crop sector in particular.

At the end of the coffee and cocoa price boom, it became apparent that the country had invested and borrowed as if the boom prices represented normal coffee and cocoa prices, and not just a short-term price change. "Public spending quadrupled between 1974 and 1977, and gross domestic investment more than doubled in constant prices, from 187 billion CFA francs in 1975 to 530 billion CFA francs in 1978."157 The profits from the export crop boom were thus taken very much for granted by the government and in some regards also spent carelessly. For example, during this period, imports of personal consumer goods were increased by 38 percent and that of manufactured goods jumped by 80 percent. $^{58}$

Despite the rapidly decreasing sales and prices of both coffee and cocoa on world markets, the Ivoirian government pursued its extensive investment and development plans, including the building of six sugar complexes in the Northern part of the country. Instead of funding these projects with the profits of the export crops as it had for the previous

\footnotetext{
${ }^{57}$ Ridler, p. 412.

${ }^{58}$ Massou, p. 95.
} 
years, it had to borrow from external private investors. In three years, its debt to GNP ratio increased from 24.2 percent up to 47 percent. $^{59}$ The country found itself severely in debt just as its main exports decreased in value..$^{60}$

In 1978, the World Bank published a report on Côte d'Ivoire entitled Ivory Coast: The Challenge of Success. ${ }^{61}$ It highlighted a number of the issues facing the Ivoirian economy at the end of the boom period. The author considered the Ivoirian development strategy one of "controlled liberalism." ${ }^{162}$ The sudden increase in state spending and the rising foreign debt were among the most serious problems discussed. In addition, the economy was noted as being increasingly vulnerable to commodity prices as its share of world coffee and cocoa production was increasing. The report also mentioned that the exploitation of virgin forest lands was reaching its outer limits and that there were fewer possibilities for import-substitution industries. Foreign capital was also no longer flowing into the country in significant amounts because of decreasing rates of return on capital. Furthermore, the report mentioned the rising tensions between Ivoirian and non-Ivoirian communities. $^{63}$

${ }^{59}$ Massou, p. 95.

${ }^{60}$ Médard, "The Historical Trajectories of the Ivoirian and Kenyan States," p. 201.

${ }^{61}$ Bastiaan A. Den Tuinder, Ivory Coast: The Challenge of Success (Baltimore, MD: The Johns Hopkins University Press for the World Bank, 1978).

${ }^{62}$ Den Tuinder, p. 20.

${ }^{63}$ Gilles Duruflé summarizes the conclusions of the World Bank report in his article "Structural Disequilibria and Adjustment Policies in the Ivory Coast," in Bonnie Campbell and John Loxley (eds.), Structural Adjustment in Africa (New York, NY: St. Martin's Press, 1989), pp. 132-168. 
The country as a whole also became unable to feed itself, a development that has even more serious consequences in an agricultural country which is obviously increasingly dependent on its export crops and the international prices of these commodities. Rice imports went up 140 per cent between 1977 and 1981; wheat imports increased by 55 per cent during that period. ${ }^{64}$

On a structural level, Ivoirian dependence on coffee and cocoa exports was at the same level in 1981 as it had been in 1960; the two commodities still represented approximately 80 per cent of the value of Ivoirian agricultural exports. ${ }^{65}$ According to Den Tuinder, "the government diversified agriculture by introducing or expanding the cultivation of oil palm, coconut, pineapple, rice, rubber, cotton and later sugarcane..."66 However, the attempts at agricultural diversification had not been particularly effective.

Côte d'Ivoire was truly at a turning point in its short post-independence history. Following almost twenty years of continued economic growth, the country was faced with a serious economic and structural crisis due to both frequently changing international commodity markets and state economic policy choices. Although radical changes in the national development policies would be expected during such a time, they did not occur. I would argue that they could not take place because of the serious nature of the Ivoirian

${ }^{64}$ Watts and Bassett, p. 16.

${ }^{65}$ Yves Fauré, "Côte d'Ivoire: Analyzing the Crisis," in Donal Cruise O'Brien, John Dunn and Richard Rathbone, Contemporary West African States (New York, NY:

Cambridge University Press, 1989), pp. 59-74, p. 64.

${ }^{66}$ Den Tuinder, p. 5. 
situation. The state had to first fix the system that had brought about these difficulties before it could alter its actual policies.

In response to all of this, the Ivoirian government first made some administrative reforms. In particular, Mathieu Ekra, named Minister of Parastatals in 1977, announced a series of strong reforms of the parastatal sector which no one believed would materialize. ${ }^{67}$ Ekra dissolved a number of parastatals and transformed others into private entities. $\mathrm{He}$ forbade direct foreign borrowing by all parastatals, since this was the primary cause of half the national debt. In addition, he aligned the high salaries of parastatal employees with the lower earnings of public administration employees.

The Ivoirian state was pressured to reform the extensive parastatal sector by the World Bank. However, Houphouet-Boigny personally defined the acceptable limits of changes to the state agencies. According to Crook, the President "dealt" with the World Bank "decisively" and "defied it constructively" in the adjustments made to the sector. ${ }^{68}$ Even though le Vieux (i.e. Houphouet-Boigny) was particularly protective of the Caisse in the reforms, he "has demonstrated a ruthless ability to call in, control or close down the patronage machine as in the case of parastatal corporations when their excesses seemed to threaten accountability and discipline throughout the rest of the state. ${ }^{169}$ The result was that the reforms of the parastatal sector were quite successful by Ivoirian standards. ${ }^{70}$

\footnotetext{
${ }^{67}$ Médard, "The Historical Trajectories of The Ivoirian and Kenyan States," p. 202.

${ }^{68}$ Crook, "Politics, The Cocoa Crisis, and Administration in Côte d'Ivoire," p. 650.

${ }^{69}$ Crook, "State, Society and Political Institutions in Côte d'Ivoire and Ghana," p. 236.

${ }^{70}$ Médard, "The Historical Trajectories of the Ivoirian and Kenyan States," p. 202.
} 
How did this first grave national crisis affect the coffee sector and the related parastatals? For coffee producers, the impact of the fall in world coffee prices following the return of Brazilian coffee was almost immediate, as the domestic price for their coffee fixed by the Caisse was set much lower, despite the original goals of the Caisse. If you recall, the Caisse was supposed to protect farmers from the ups and downs of the international commodity prices by saving during the good years. The impressive profits accumulated by the Caisse in the mid-1970's were not saved to help the producers in more difficult times; on the contrary, they were spent on other non-coffee related investments in the agro-industrial sector. As a result, the Ivoirian economy was in trouble for two reasons, both related to coffee production. First, it had overinvested and overspent the boom profits resulting from coffee and cocoa exports and was now heavily endebted. Second, it did not have the means to protect coffee producers from the dramatic drop in world prices. Small coffee producers who had in large part been the engine of Ivoirian economic growth were now in a dismal situation. They reacted to their predicament in large part by not investing additionally in their plots. They did not plant new coffee trees even though the ones currently on their lots were quite old and unproductive. First and foremost, they were interested in cutting their losses.

Despite the crisis faced by coffee producers and the country as a whole, the Caisse came through these first difficult years relatively unscathed, most likely because it was fulfilling its mission vis-a-vis the Ivoirian state. The Caisse was not particularly affected by the parastatal reforms. It was only affected by the rulings that were made across the parastatal sector, such as those affecting the salaries of its employees and its inability to 
borrow abroad independently from the Ivoirian state. The SATMACI, on the other hand, "was severely affected by the purge of the parastatals." "71 It was integrated into the Ministry of Agriculture, along with 58 other parastatals, and thus was not mentioned as a separate entity for several years, although it would later reappear.

The economic problems faced by Côte d'Ivoire were obviously not simple; they required deliberate actions beyond the restructuring of the state. These came in the form of Côte d'Ivoire's first Structural Adjustment Plan (SAP) put together by the World Bank and the International Monetary Fund in 1981. According to the World Bank, HouphouetBoigny called upon these institutions for their assistance, despite its reticense. ${ }^{72}$ The 1981-1984 SAP for Côte d'Ivoire to which Houphouet-Boigny and the twon financial institutions agreed had two primary goals: to decrease the budget and current account deficits and to stabilize the debt servicing at 30 per cent of the country's budget. ${ }^{73}$ It was to be supported by a World Bank loan.

Until 1980, the World Bank had barely been involved in Ivoirian economic affairs. ${ }^{74}$ Its investment loans prior to 1980 represented less than one per cent of the Ivoirian GDP. In 1975, the World Bank had sent an economic memorandum to Ivoirian

${ }^{71}$ Crook, "Politics, The Cocoa Crisis, Administration in Côte d'Ivoire," p. 662.

${ }^{72}$ World Bank, Côte d'Ivoire: Revue de l'Aide de la Banque Mondiale Au Pays (Washington, DC: World Bank, 1999), p. 4.

${ }^{73}$ Femi Aribisala, "The Political Economy of Structural Adjustment in Côte d'Ivoire," in Adebayo Olukoshi, R. Omotayo Olaniyan and Femi Aribisala (eds.), Structural Adjustment in West Africa (Lagos, Nigeria: Pumark Nigeria Limited, 1994), pp. 126-141, p. 129.

${ }^{74}$ World Bank, p. xiv. 
state leaders with regard to their ambitious investment plans, warning them that they were trying to do too much. However, because of their lack of leverage, the World Bank could not do much to change the Ivoirian course. Following the beginning of the first SAP, the World Bank was providing 2.4 per cent of Côte d'Ivoire's GDP in structural adjustment loans and thus became more involved across the board in the nation's economic situation and policies.

The reviews of the first Structural Adjustment Plan are mixed. While the World Bank claims that the plan's objectives were met, Aribisala writes that it was ineffective because of worsening international economic conditions and a serious drought in Côte d'Ivoire. ${ }^{75}$ Between 1980 and 1983, the world recession and monetary tightening caused Ivoirian terms of trade to decrease by 16 per cent and its interest rates to increase. Ivoirian public debts thus continued to escalate.

Côte d'Ivoire's first significant drought had a dramatic impact on the Ivoirian commodity crops. In 1983 , the country produced only one third of the coffee it had produced in the previous year. ${ }^{76}$ The lengthy dry spell was in part the result of the deforestation of the Southern Côte d'Ivoire over the past twenty or more years. The situation was made worse, however, by the numerous deliberate fires set on coffee and cocoa plantations. 30000 hectares of coffee and cocoa plantations were burned in 1983

\footnotetext{
${ }^{75}$ Aribisala, p. 129.

${ }^{76}$ Fauré, p. 60.
} 
alone. ${ }^{77}$ No official explanation was provided for the fires, but those responsible were to be depossessed of their lands and pursued in court. It is possible that they were set by producers out of desperation. The lower prices, drought, and unavailability of economic assistance may have been too much for some.

The end of the drought in 1984 and a miniboom in coffee prices between 1984 and 1986 helped to briefly brighten Côte d'Ivoire's economic picture independently from the second Ivoirian SAP which went into effect in $1985 .^{78}$

During these difficult years, producer interest in the GVCs mentioned previously continued to be quite low. ${ }^{79}$ Even in the communities where these cooperatives had been put into place, the producers did not necessarily sell their crops to them. In the region of Gagnoa, 83 villages out of 153 had GVCs. Out of the 83 , only 23 GVCs sold directly to the factory taking advantage of the potential savings. Seventy per cent of the producers in the GVCs still sold to intermediaries. The advantage of this choice for the farmers is that they can get advance payments on their crops from intermediaries that they cannot get from the GVCs. In times of crisis, this is quite important to the peasant and his family even though "the intermediaries were getting rich on the backs of the peasants." ${ }^{80}$ In

${ }^{77}$ Saliou Koné, "La Production du Café et Du Cacao En Baisse," Fraternité Matin, May 25, 1984, p. 10.

${ }^{78}$ Jean-Paul Azam and Christian Morrisson, The Political Feasibility of Adjustment in Côte d'Ivoire and Morocco (OECD, 1994), p. 55.

${ }^{79}$ D. M. Abiali, "Café-Cacao: Des GVC peu dynamiques," Fraternité Matin, June 21, 1983, p. 11.

${ }^{80}$ Abiali, p. 11. 
response to this, beginning in 1986, the state began allowing GVCs to provide monetary advances to peasants so that they could compete with the marketing intermediaries. ${ }^{81}$

Unfortunately, this policy change and the SAP in place were not able to make a significant difference for the producers as the world coffee prices went down once more at the end of 1986, the combined result of a slight drop in coffee prices and a significant drop in the value of the French franc vis-a-vis the dollar. It was clear at this point that coffee production in Côte d'Ivoire was in a serious crisis. In the public presentation of producer prices for the 1986-87 coffee season, the focus was on coffee and cocoa producer prices and the lack of profits available for the Caisse. "This [situation] does not allow for the Caisse to carry out its functions. ${ }^{182}$ This is the first public indication (that I have found) which mentioned the fact that the Caisse transfers money to other parts of the state and that the Caisse was at this point in a difficult situation given producer prices.

The Caisse de Stabilisation which had provided approximately $\$ 596$ million to Côte d'Ivoire's investment budget in 1985 and 1986, was unable to contribute anything to investment in 1987 and $1988 .{ }^{83}$ It had a surplus of 4.2 per cent in 1986 but showed increasing deficits in the following years. In 1987, its deficit represented 1.9 per cent of GDP; this deficit increased to 3.4 per cent in 1988 and 5.4 per cent in $1989 .{ }^{84}$ Cotton prices also decreased in 1989 adding to the Caisse's financial liabilities.

${ }^{81}$ Doumbia Mori, "Mettre fin a la vente hors de la circonscription," Fraternité Matin, October 8, 1986, p. 12.

82 "Les nouveaux prix: un grand sacrifice," Fraternité Matin, October 28, 1986, p. 24.

${ }^{83}$ Aribisala, p. 131.

${ }^{84}$ Azam and Morrisson, p. 63. 
In addition to these financial difficulties, during the course of the 1986-87 coffee season, the Caisse de Stabilisation bought a total of 50,000 tons of dust and rocks which had been sold as coffee. ${ }^{85}$ This represented a loss of 10 billion CFA francs for the Caisse and therefore for the state. The Minister of Agriculture Denis Bra-Kanon issued a warning to those involved in the practice of mixing dust and rocks with coffee. In my opinion, this is another act of desperation on the part of producers who are facing extremely difficult situations. In many instances, these farmers simply wanted to increase their meager incomes. However, this deliberate act could also be viewed as a silent rebellion against the Ivoirian marketing system. This could be one weapon for the weak, to use James Scott's terminology. ${ }^{86}$

During this time, the Minister of Agriculture announced a new plan for Ivoirian coffee. The new goal would be to produce 150,000 more tons of coffee by the year 2000 . The state was to spend 20 billion CFA francs on this effort and make 36 million cuttings available to producers. One of the goals was to replant 10,000 hectares. A bonus would be given to the farmers who assisted in this effort.

One of the methods put forth by the Ministry of Agriculture and in particular the SATMACI (which reappeared with the approval of the World Bank) to increase Ivoirian coffee production was to introduce a new variety of coffee, the Arabusta. Côte d'Ivoire until now had been producing exclusively Robusta coffee. Arabica coffee is a better

85 "Café: 150, 000 tonnes supplémentaires dans 13 ans," Fraternité Matin, October 28, 1986, p. 23.

${ }^{86}$ James C. Scott, Weapons of the Weak: Everyday Forms of Peasant Resistance (New Haven, CT: Yale University Press, 1985). 
tasting, more sought out variety of coffee but Côte d'Ivoire cannot grow it for climatic reasons. The goal then was to create a new variety of coffee which would taste more like arabica but could be grown very productively on Ivoirian territory. The original goal had been for the country to start producing 2000 tons of Arabusta annually in $1986{ }^{87}$ This did not happen, however, because of technical problems encountered on the SATMACI's 60 hectare experimental plot. First, the productivity was lower than desired. SATMACI was seeking a productivity of two tons per hectare but only succeeded in attaining a productivity of one ton per hectare. Second, insects and diseases had been found in the plants. Efforts were thus slowed down but all involved remained hopeful. "At a time when the Ivoirian coffee orchard is looking for its second wind, we estimate that the mastery of the Arabusta hybrids opens totally new and prosperous possibilities for the Ivoirian coffee industry." 88

Between 1965 and 1986, the positions of coffee and cocoa were reversed in the Ivorian economy. According to Scheider, "coffee's share of exports fell from 38 percent in 1965 to 20 percent in 1986 , while cocoa's share increased from 17 percent to 39 percent." 89 Côte d'Ivoire, however, was still the third producer of coffee in the world behind Brazil and Colombia.

The Ivoirian situation just seemed to be getting worse each year in the latter half of the 1980's. In May 1987, Houphouet-Boigny suspended all of the nation's debt payments

\footnotetext{
${ }^{87}$ Hien Solo, "La saga de l'arabusta," Fraternité Matin, June 8, 1989, p. 6.

${ }^{88}$ Solo, "La saga de l'arabusta," p. 6.

${ }^{89}$ Schneider, p. 20.
} 
and, in doing so, took a step back from the structural adjustment plans. The World Bank and IMF responded by suspending temporarily all assistance to Côte d'Ivoire. ${ }^{90}$ The aid would resume in late 1989 when the Ivoirian government and the IMF could agree on a stand-by agreement regarding the direction of the reforms.

In 1988, for the first time, Côte d'Ivoire fell short of producing its 300,000 ton quota of coffee as set by the International Coffee Agreement. ${ }^{91}$ This was due to the increasingly old trees on coffee plantations. Urgently, "the old plantations have to be ripped out of the ground and replanted with cuttings currently available at the SATMACI."92 This shortage was compounded by the extremely low international price of cocoa and the losses of the Caisse.

Following the collapse of the International Cocoa Agreement in 1987, HouphouetBoigny decided to withhold the 1988-89 cocoa crop in hopes of pushing the price up. His gamble, however, did not pay off and a few months later, this crop had to be sold on the international market at a lower price because of quality concerns. "This crop retention scheme. however, had two serious consequences: the first was to have given Asian cocoa producers the opportunity to penetrate new consumer markets; the second is to have accelerated the aggravation of the financial crisis, not just of the coffee and cocoa sectors

${ }^{90}$ Lionel Demery, "Côte d'Ivoire: Fettered Adjustment," in Ishrat Husain and Rashid Faruqee (eds.), Adjustment in Africa: Lessons from Country Case Studies (Washington, DC: The World Bank, 1996), pp. 72-152, p. 97.

91 "Le plan relance du café sera maintenu," Fraternité Matin, August 29, 1988, p. 21. 92 "Le plan de relance café sera maintenu," p. 21. 
but of the entire Ivoirian economy with a liquidity crisis unlike any other seen before, the collapsing of large banks and the rapid increase in the state's debt."193

\section{$\underline{\text { Conclusions }}$}

The news for the Ivoirian economy was not much better in 1989, with the collapse of the International Coffee Agreement. The next chapter will detail the political, economic and social implications of the collapse of the ICA for the already weak Ivoirian economy. It will also discuss why the disintegration of the agreement marks an important turning point in the Ivoirian coffee story.

The history of the Ivoirian coffee sector as outlined in this chapter will serve as the background for the discussions in the next chapter with regard to the coffee sector and more specifically the role of the Caisse and the SATMACI throughout the crisis. In this chapter, we have reviewed the evolution of the political economy of coffee in Côte d'Ivoire. We discussed the impact that the colonial policies and structures had on the political and economic development of the independent country. We detailed how the new nation experienced impressive economic growth thanks to coffee and cocoa during its first almost twenty years and faced growing problems over the following decade. Throughout the thirty-year period, we considered the particular role and position of the Caisse de Stabilisation as a state agency meant to structure and organize the Ivoirian export crop sector while benefiting other parts of the national economy.

93 "Agro-industries: des filières face au défi de la compétitivité, Marchés Tropicaux et Méditerranéens, July 2, 1993, p. 1696. 
Houphouet-Boigny points out the importance of the Caisse in the national

economy in the following statement:

It is thanks to the Caisse that without awaiting the promises of the World Bank we have been able to build the roads linking Katiola and Korhogo, Man and Odienne, by way of Touba; it is thanks to the Caisse that we have been able to expand electrification, that we have been able to organize the "fetes tournantes" ... It is thanks to the Caisse that we have been able to wage war on regional disparities in development. ${ }^{94}$

Although the 1980 's was a turbulent decade for Côte d'Ivoire, fundamentally not much has changed for the country yet. The specifically Ivoirian economic structures existing at the time of decolonization are for the most part still in place in 1989. The Ivoirian state still has a strong grip on the political, economic and societal spheres. The crises the nation has gone through up to this point have not changed the way Felix Houphouet-Boigny rules the country or the lack of input of societal and specifically rural forces in the country's affairs. This lack of engagement on the part of society in the agricultural sphere and the engagement of the state in the form of the Caisse de Stabilisation places the Ivory Coast in Michael Bratton's second scenario for peasant-state relations.

We will see in the next chapter how the crisis of Côte d'Ivoire in 1989 changes the role of the two coffee parastatals and state-producer relations in general. The history of the coffee sector and the situation in 1989 really set the stage for the significant national and sectoral events of the 1990's.

${ }^{94}$ Marchés Tropicaux et Méditerranéens, 6 October 1989, p. 2852. 


\section{CHAPTER VII}

\section{THE IVOIRIAN COFFEE SECTOR AND ITS PARASTATALS SINCE 1989}

The collapse of the International Coffee Agreement in late 1989 worsened the already precarious economic situation of Côte d'Ivoire described in the previous chapter and precipitated significant political and economic changes affecting the country's coffee sector. In this chapter, I will describe and analyze events concerning and changing the Ivoirian coffee sector from 1989 to 1999 . My focus will be on the transformation of the parastatal entities involved in the evolving political economy of coffee as well as on the relations between the state and Ivoirian societal actors.

A discussion of the Ivoirian coffee sector in the 1990's must additionally include a presentation of the changing overall political and economic context in the country. This needs to be done because the coffee and cocoa sectors in combination are at the very crux of the Ivoirian political economy. Because of this, the crisis of the markets for these two crops ripples through the rest of the economy. Events in other parts of the political and economic realms also affect the coffee sector, sometimes directly and sometimes indirectly. Losch gives us some perspective on this problem, noting:

The current crisis of the coffee and cocoa sectors clearly goes beyond specific sectoral problems and refers more largely to a crisis of the mode of political regulation, the future of which is uncertain... one should not mistake one crisis for another, the crisis of the plantation economy does it not hide more directly a crisis of political legitimacy? ${ }^{1}$

${ }^{1}$ Bruno Losch, "A la recherche du chainon manquant pour une lecture renouvelée de l'économie de plantation ivoirienne," in Bernard Contamin and Harris Memel-Fotê (eds.), Le modèle ivoirien en questions: crises, ajustements, recompositions (Paris, France: 
Taking into consideration the position of the coffee sector in the Ivoirian political economy, this chapter will attempt to answer several questions: How did the events in the coffee sector affect the relevant parastatal agencies and the peasants themselves? What actions did the state take to remedy the situation? How did the farmers react to the crisis and its aftermath? What happened to relations between the peasants and the state in the evolving situation?

I will argue in this chapter that the changing international coffee economy in combination with other factors has transformed the coffee parastatals of Côte d'Ivoire as well as state-society relations in the coffee sector. The state agencies would in the final analysis be eliminated, in large part because of the key position of the World Bank and the International Monetary Fund vis-a-vis the Ivoirian state. Ivoirian coffee producers challenged the Ivoirian state's perspectives and actions during this period for the first time in the country's history.

$\underline{\text { Côte d'Ivoire and the quest for a new International Coffee Agreement }}$

Upon the collapse of the ICA, the Ivoirian state faced a number of difficult international agricultural issues simultaneously. As seen at the end of the previous chapter, the International Cocoa Agreement collapsed in 1987. The Ivoirian economy was thus already dealing with one agricultural crisis which had spread to other parts of the economy thanks to Houphouet-Boigny's policy choices. This worsened the impact of the ICA's dissolution on Ivoirian agriculture and specifically the institutions meant to support

Editions Karthala, 1997), pp. 205-230, p. 227. 
it. It also made the Ivoirian state more active in its attempt to renew global negotiations for a new coffee agreement and more dependent on the assistance from the international financial institutions.

It was thus under tense and difficult circumstances for Ivoirian agriculture that discussions for a new International Coffee Agreement fell apart in September 1989. Côte d'Ivoire was very interested in the renewal of the ICA from the beginning and was quite engaged in the multilateral negotiations for a new coffee agreement. Its government worked to bring differing parties to the negotiating table and pushed for an agreement. It was very vocal in its discussion of the need for a new agreement. In addition, it was also playing a prominent role in the discussions regarding the renewal of the cocoa agreement. Felix Houphouet-Boigny and his government understood the harsh realities of the Ivoirian economic context and knew that some form of stability in world coffee and cocoa prices would help the national economy in its recovery.

As will be discussed in more detail in the next sections, Houphouet-Boigny wanted the citizens of Côte d'Ivoire to believe that the problems of the national economy were caused exclusively by external market prices and not at all by the internal structure of the crop production and marketing system. The actions of Côte d'Ivoire in the international sphere thus could not be ambiguous.

The collapse of the international agreements dealing with its two most important primary commodities had obviously further weakened the economic position of the Ivoirian state vis-a-vis the international financial community. This in turn would affect its ability to deal effectively with the International Monetary Fund and the World Bank. The 
Ivoirian state was no longer able to place demands on the IMF and the World Bank; on the contrary, these institutions were placing limitations on the Ivoirian state. The IMF and the World Bank did not renew their loans to Côte d'Ivoire until the Ivoirian leaders had announced reductions in the producer prices of coffee and cocoa in late $1989 .^{2}$

Interestingly, the French Caisse Centrale de Coopération Economique (Central Fund for Economic Cooperation, CCEE) "took the unusual step of undermining the position of these international financial institutions by pledging loans to Côte d'Ivoire in the form of advance on funding from other sources." ${ }^{\text {"3 }}$ The French clearly wanted to distinguish their "special" relationship with Côte d'Ivoire from that of other Western countries and organizations.

Côte d'Ivoire, like many other coffee-producing countries, was also concerned about the ICA quota it would receive should the coffee agreement be renewed. Thus, following the ICA breakdown, the state through the Caisse sold off the coffee stored in national warehouses. Over time, Côte d'Ivoire had been producing annually more than its quota of coffee and storing it. The country has the capacity to store up to 370,000 tons of coffee over a period of time. ${ }^{4}$ This storage capacity is greater than what Côte d'Ivoire had

2 World Bank, Côte d'Ivoire: Revue de l'aide de la Banque Mondiale au pays (Washington, DC: World Bank, 1999), p. 13.

${ }^{3}$ Femi Aribisala, "The Political Economy of Structural Adjustment in Côte d'Ivoire," in Adebayo O. Olukoshi, R. Omotayo Olaniyan and Femi Aribisala (eds.), Structural Adjustment in West Africa (Lagos, Nigeria: Pumark Nigeria Limited, 1994), pp. 126-141, p. 137.

${ }^{4}$ Dadié Attebi, Le Défi Africain: L'urgence d'une alternative économique en Côte d'Ivoire (Paris, France: L'Harmattan, 1995), p. 22. 
been exporting on average on the world market each year, namely 200,000 tons. This action reduced the costs of storage incurred by the state and could have increased the Ivoirian market share in a new ICA. Because this action was repeated by numerous other coffee-exporting countries, it further depressed the price of coffee on the international scene in the 1990's.

When it became clear in early 1993 that a new International Coffee Agreement would not be signed, Côte d'Ivoire actively pursued other ways to increase and stabilize the price of coffee. Along with Colombia and Brazil, it was quite involved in the creation of the Association of Coffee-Producing Countries in Kampala, Uganda in 1993. The members of this new association decided to withdraw 240,000 tons of coffee from the markets in an attempt to increase the commodity's prices. ${ }^{5}$ They agreed that they could withhold up to 20 per cent of their crops in order to push world prices up. Thanks to the efforts of this organization, the prices of coffee did go up briefly in 1993/94.

The prices of the green beans, however, fluctuated over the next few years mostly independently from this association's work. It was clear to the Ivoirian authorities as it was to other coffee-producing countries that the economic stability of the ICA could not be reproduced in other types of arrangements. Maybe the time had come for coffeeproducing countries to reform their internal production system since the international scheme had mostly fallen apart.

\footnotetext{
5 "L'union fait la force," Jeune Afrique, March 23-29, 1995, pp. 48-49, p. 48.
} 
The Ivoirian Coffee Sector Falls Apart (September 1989 - November 1990)

The economic crisis which had begun prior to the collapse of the ICA but was consolidated and worsened by it brought about some surprising and quick developments in the Ivoirian political sphere, which would in one way or another impact all the actors in the coffee business.

Because the government was caught off guard by the collapse of the International Coffee Agreement and the events that preceded it, the government was not able in the first few months to formulate a coherent and consistent economic policy to respond to the crisis. Houphouet-Boigny and his cabinet were not prepared for the situation and were especially not ready to provide solutions that would please frustrated Ivoirian citizens.

The Ivoirian economy as a whole was in crisis in part because of the fluctuating international markets for its two main commodities. However, it was also in crisis because of the very structure of the Ivoirian export agriculture, as discussed in the previous chapter. The economy as a whole was still very dependent on its main two commodities. Until this point, the world prices of coffee and cocoa had allowed for the Caisse to provide coffee producers with low but stable commodity prices while keeping for itself and other governmental agencies the difference between the two prices. The profits of the Caisse de Stabilisation during the good times were simply not saved for the harsh times; they were transferred to different government accounts where they would be used for other purposes. They were mostly used to develop other areas and economic sectors of the country or support political patronage and not specifically to help coffee producers in 
times of crisis. Through various other state agencies, the state had invested its resources into other sectors such as industrial sugar complexes in the Northern part of the country, for example. Unfortunately, these investments had not been particular fruitful and thus could not at this stage provide any relief to the dire Ivoirian economy. On the contrary, the state was involved in too many big projects which were not financially productive and draining the national economy.

As mentioned previously, the institutions in place in the Ivory Coast to deal with cocoa and coffee production were the same. The collapse in cocoa prices in 1987 had already begun to drain resources from the Caisse de Stabilisation and the SATMACI, as the state did try to maintain cocoa prices at a reasonable level following the failure of the International Cocoa Agreement. The situation was so dire that some believed "at the onset of the 1989-90 main season that the Caisse faced certain bankruptcy," considering the promised producer prices and the world prices of coffee and cocoa and the general financial malaise in the country. ${ }^{6}$ The collapse of the coffee agreement was really the final blow to the status quo for the two parastatal agencies and the Ivoirian state's way of doing business. I argue that the breakdown of the coffee agreement marks the beginning of a number of transformations in the Ivoirian political, economic and social realms. Change would not necessarily take place quickly but it did start to take place at this point.

Public perception of the situation was very important to the Ivoirian political leaders as they did not want to be blamed for the country's problems. President

${ }^{6}$ Richard C. Crook, "Politics, The Cocoa Crisis, Administration in Côte d'Ivoire," The Journal of Modern African Studies, 28, 4 (1990), pp. 649-669, p. 660. 
Houphouet-Boigny and other government officials put forth early on an "official explanation" for the troubles of the Ivoirian economy and they made a point of presenting their perspective again and again. Houphouet-Boigny wanted to make sure Ivoirian citizens believed that the country's problems were linked almost exclusively to the international markets. Houphouet-Boigny, for example, stated:

We have the impression that our products are being played in a grand casino. It is beautiful, it is human. But those who go to the casino need to be conscious of what they will win and what they will lose because the casino will always win. Whether you play, win or lose, there will always be something left for the casino. But we do it with our own money. But what is being played with? It is our money, our primary products that are being played with. ${ }^{7}$

The Minister of Finance, Moise Koumoue Koffi, also made statements about the crisis, claiming repeatedly: "It is caused by external factors." 8 The goal behind this "official version" of the country's difficulties was to keep the pressure and the responsibility off the government as much as possible, despite its own contribution to the problems.

It was imperative for the Ivoirian state to take serious and quick actions to redress the country's economic situation in late 1989. The government, however, first only took rather small steps towards bettering the situation for the state and for the crop producers. Just prior to the breakdown of the international coffee agreement, the government had launched a new program with the assistance of the SATMACI to rejuvenate the country's

7 "Le President à propos des sacrifices consentis," Fraternité Matin, March 7, 1990, pp. 11-15, p. 13.

${ }^{8}$ Hien Solo, "Pour sortir de la crise: le plan de bataille de Moise Koumoue Koffi," Fraternité Matin, February 8, 1990, p. 21. 
very old coffee trees. An important number of coffee farmers had thus just pruned their bushes around the time of the collapse of the agreement. This labor intensive process signified that the farmer's production possibilities would be low for a few years as the new bushes grew to their productive size. This in itself would mean a significant loss of income for the farmers for several years and would only worsen the impact of the international price changes on the farmers. It thus became necessary for the government to offer 60,000 CFA Francs to the farmers who had pruned their trees but it is not clear how many affected farmers actually got this money. ${ }^{9}$

In addition, the SATMACI made 186 specialists in cooperative development available to assist in the development of producer cooperatives and the amelioration of the peasants' situation. ${ }^{10}$ Even though during the previous thirty years of Ivoirian history cooperatives had been unable to make a place for themselves in the agricultural sector, the government wanted the GVCs to now take on a more active role in coffee production and marketing. Farmers did not, however, view participation in these cooperatives as in their best interest, specifically because of their track record.

9 Jennifer Widner, "The Discovery of "Politics: Smallholder Reactions to the Cocoa Crisis of 1988-90 in Côte d'Ivoire," in Thomas M. Callaghy and John Ravenhill (eds.), Hemmed In: Responses to Africa's Economic Decline (New York, NY: Columbia University Press, 1993), pp. 279-331, p. 293.

${ }^{10}$ Sosthène Nicaise Ahanda, "Le désengagement de l'Etat dans la gestion des coopératives et groupes d'initiative commune au Cameroun: Enjeux et impact sur les principales filières agricoles, perspectives comparatives avec le cas de la Côte d'Ivoire," in Bernard Contamin et Harris Memet-Fote (eds.), Le modèle ivoirien en questions: crises, ajustements, recompositions (Paris, France: Editions Karthala, 1997), pp.161-169, p. 162. 
The government also tried to sharply and quickly reduce much of its on-going investments throughout the country. Unlike in 1979-1980, the state pushed to rapidly decrease its obligations and the size of some of its larger industrial projects. However, because of the weight of the state's overall financial commitments, this attempt did little to change the state's rapidly deteriorating financial situation. ${ }^{11}$

As mentioned in the previous chapter, the World Bank and the IMF suspended their assistance to Côte d'Ivoire in 1987. They were prepared to resume it in 1989, provided the Ivoirian government took one key step to ameliorate the general economic situation of the country: lower the domestic producer prices of coffee and cocoa. This would impact coffee production at every level and would have a drastic effect on the producers. Thus, during the 1989-1990 season, the producer price of coffee was reduced from 200 CFA Francs per kilogram $(\$ .60)$ to 100 CFA Francs. ${ }^{12}$ The price of 100 CFA francs was considerably higher than the world price of Robusta coffee at that point, 45 CFA Francs per kilogram. ${ }^{13}$ The government was obviously subsidizing the producers but could not afford to do so, considering its financial crisis.

${ }^{11}$ Harmut Schneider, Adjustment and Equity in Côte d'Ivoire (Development Centre of the Organisation for Economic Cooperation and Development, 1992), p. 13.

${ }^{12}$ Kanvaly Diomande, "Finances publiques et poids des interventions de l'Etat dans l'économie ivoirienne," in Bernard Contamin and Harris Memel-Fotê (eds.) Le modèle ivoirien en questions: crises, ajustements, recompositions (Paris, France: Editions Karthala, 1997), p. 116 and "Agro-industries: des filières face au défi de la compétitivité," p. 1699.

${ }^{13}$ Economist Intelligence Unit, EIU Country Profile 1993/94 Côte d'Ivoire Mali, (London, UK, 1994) p. 16. 
The main goals of the World Bank and the IMF in their structural adjustment plan in late 1989 were to: reduce government budget deficits, privatize a number of state agencies and reform the financial sector. ${ }^{14}$ This would imply substantial reductions in government expenditures and tax increases. The IMF's agreement with the Ivoirian government in 1989 was a stand-by agreement. It would become a full-pledged agreement with identical goals in 1991.

During this time Houphouet-Boigny was busy crafting his image of the ideal Ivoirian peasant in this time of crisis. He and his colleagues were eager to put forth the idea and appearance of Ivoirian farmers who willingly sacrificed themselves for the good of the nation. This perception might help not only appease some of the farmers but also push other societal groups to be more accepting of the stressful situation. Here is an example of the type of speech he would make to a gathering of peasants:

I have understood your reaction: always at the service of your country; it is your work that enables us all to live. You have always known how to be the example when it comes to sacrifice, in the field, at home, and today you accept to lose 200 billion CFA francs, which represents the loss on our two key products, coffee and cocoa. I do not have the words to give you all my warm and brotherly thanks. I do not have the words to magnify the example of sacrifice that you have consented to for the benefit of your country. ${ }^{15}$

Did the Ivoirian farmers really voluntarily sacrifice their incomes for the good of the nation, as Houphouet-Boigny claimed many times? The answer is clearly no. The coffee

${ }^{14}$ Robert Naiman and Neil Watkins, "A Survey of the Impacts of IMF Structural Adjustment in Africa: Growth, Social Spending, and Debt Relief," Center for Economic Policy and Research paper, April 1999, p. 11.

15 "Le chef d' état à propos des mesures envisagées: 'Portez le message à vos frères'," Fraternité Matin, March 12, 1990, p. 7. 
producers, however, were among the social groups most directly affected by the Ivoirian economic crisis. Their income decreased dramatically following the domestic producer price change. For Widner, "by 1990 the collapse of the cocoa- and coffee-based 'miracle ivoirien' had produced severe reductions of standards of living in the countryside, increasing demands of rural relatives upon urban kin, and a clear sense of dissatisfaction with government." ${ }^{16}$ Poverty had become more prevalent in rural areas and increased more severely for export crop producers than for other Ivoirian farmers. ${ }^{17}$

Few details, however, are available as to the specific economic and social problems facing the Ivoirian coffee farmers starting in late 1989. The state-sponsored Ivoirian press has not discussed this topic. In addition, the academic literature on Côte d'Ivoire does not really explore this aspect of the situation. The focus for all seems to be on the growing, political organization of the Ivoirian peasants. ${ }^{18}$ The increasing political awareness of the Ivoirian commodity producers during this time is quite interesting. The producers in effect slowly began to engage the state for the first time in the country's history.

${ }^{16}$ Jennifer Widner, "Two Leadership Styles and Patterns of Political Liberalization," African Studies Review, 37, 1 (April 1994), pp. 151-174, p. 159.

${ }^{17}$ Christian Grootaert, "Structural Change and Poverty in Africa: A Decomposition Analysis for Côte d'Ivoire," The Journal of Development Economics, 47 (1995), p. 375401, p. 394.

${ }^{18}$ For example: Catherine Boone, "State Building in the African Countryside: Structure and Politics at the Grassroots," The Journal of Development Studies, 34, 4 (April 1998) pp. 1-31 and Dwayne Woods, "The Politics of Organising the African Countryside: Rural Cooperatives in Côte d'Ivoire," The Journal of Modern African Studies, 37, 3 (September 1999), pp. 489-507. 
At the beginning of 1990, Ivoirian coffee producers did not have real channels through which to voice their concerns and opinions. They tried to change their circumstances by pursuing other avenues. For example, they could exercise their influence indirectly by having their urban-based relatives protest or push for their demands. They could also burn crops or store them even though these were not economically viable solutions for farmers in crisis situations. ${ }^{19}$ In addition, they could modify their land tenure arrangements with a shift away from rental or wage contracts towards share contracts. They might retreat from farming and use their family relations to move into other sectors of the economy. ${ }^{20}$ They did not belong to state-sponsored cooperatives or seek them out in their predicament because the latter did not have any money; the farmers preferred to work with middlemen who could pay them cash for their crops, even if they received less than the official producer price for their crop. ${ }^{21}$ The coffee producers were thus at first bypassing direct political participation and using the economic alternatives available to them to survive their trying situation.

Large producers had a different response to the worsening economic crisis. They started requesting audiences with relevant government officials in Abidjan and travelling to

${ }^{19}$ Jennifer A. Widner, "Political Reform in Anglophone and Francophone African Countries," in Jennifer A. Widner, Economic Change and Political Liberalization in SubSaharan Africa (Baltimore, MD: The Johns Hopkins University Press, 1994), pp. 49-79, p. 65 .

${ }^{20}$ Widner, "The Discovery of Politics," p. 283.

${ }^{21}$ Interview of Mr. Antoine, Agricultural Attache, United States Embassy, July 7, 1997. 
the capital to meet with them and discuss their problems. ${ }^{22}$ Although these meetings may have made the individual farmers feel better, no real action on behalf of the government was taken to relieve their suffering.

The terrible situation of the overall national economy in general was felt by different segments of Ivoirian society and, starting in February 1990, the frustrations of Ivoirians could be seen in the streets of the capital where large demonstrations took place over a period of months. ${ }^{23}$ This was the first time in the country's history that such diverse groups of the population came together to demand change, thus marking the serious nature of their protest. Farmers, businessmen, government employees and students were all particularly well represented in the streets of Abidjan. Diverse demands were put forth by the different groups represented. Some wanted higher prices for their primary commodities; others demanded the resignation of President Houphouet-Boigny. ${ }^{24}$ Civil servants were protesting salary cuts of 15 to 40 per cent. ${ }^{25}$

Despite the massive protests, President Houphouet-Boigny and his cabinet were unable to provide economic relief to the demonstrators for several reasons. First, the tightness of the state's financial means was being felt throughout the country. Even the

${ }^{22}$ Jennifer A. Widner,"The 1990 Elections in Côte d'Ivoire," Issue, Volume 20, 1(Winter 1991), pp. 31-40, p. 33.

${ }^{23}$ Widner, "The 1990 Elections in Côte d'Ivoire," p. 31.

24 "Clashes and unrest grow fiercer in Ivory Coast," The New York Times, March 3, 1990, p. 3.

${ }^{25}$ Robert J. Mundt, "Côte d'Ivoire: Continuity and Change in a Semi-Democracy," in John F. Clark and David E. Gardinier (eds.), Political Reform in Francophone Africa (Boulder, CO: Westview Press, 1997), pp. 182-203, p. 190. 
President's personal slush funds had mostly disappeared during this time with the building of the exhorbitant Basilica and other impressive buildings in his hometown of Yamoussoukro. Second, Côte d'Ivoire's leeway with the World Bank and the International Monetary Fund had decreased considerably. The government would need considerable foreign assistance to get out of this crisis and thus had to agree to certain points in the restructuring of the economy. Losch suggests that if Houphouet-Boigny had not waited so long to reduce the domestic producer price of coffee, the Ivoirian state would not have had to expose itself as much to the international financial institutions called in to help. ${ }^{26} \mathrm{He}$ believes the government could thus have had more leeway to resolve the issues at hand.

The Ivoirian President had not anticipated these large marches and strikes. His initial reaction was to respond to this situation as he had to previous ones, by calling out the army and threatening the protesters with sanctions. ${ }^{27}$ However, the size and the frequency of the protests led him to more drastic changes supported by the World Bank and the IMF. He decided to relieve some of the pressure placed on his government by opening up the national political system and creating a multiparty system in Côte d'Ivoire. On May 3, 1990, he approved national multi-party elections for November 1990. According to Mundt, the President was simply seeking to buy himself some time to turn

${ }^{26}$ Bruno Losch, "A la recherche du chainon manquant," p. 224.

${ }^{27}$ Dwayne Woods, "Côte d'Ivoire: The Crisis of Distributive Politics," in Leonardo Villalon and Phillip A. Huxtable (eds.), The African State At a Critical Juncture: Between Disintegration and Reconfiguration (Boulder, CO: Lynne Rienner Publishers, 1998), pp. 213-232, p. 227. 
around the economic situation. ${ }^{28}$ He apparently approved of these elections only because his economic and political options were so limited.

According to Widner, the political reforms came about as a result of four types of pressures. ${ }^{29}$ First, the Ivoirian elites felt the impact of the economic crisis quite seriously as it rippled throughout the economy, with the collapse of their banks, the elimination of some of their jobs and/or institutions. The harshest government measures to be taken in the crisis would occur after the elections but, prior to them, the crisis itself ravaged the economic position of the elites.

There was also a rise in the number of groups that could exert pressure on the government because they were not dependent on them for economic resources. ${ }^{30}$ As mentioned, the richer farmers headed to Abidjan to put forth their requests. In addition, transporters throughout the country went on strike a number of times, blocking traffic and roads. They did not depend directly on the government for their economic welfare and could thus create mayhem if they were not given a voice.

The other two forces pushing Houphouet-Boigny to his policy change reform were political in nature. ${ }^{31}$ The President and his PDCI advisors were convinced that their party could win easily if the elections took place quickly. As the sole party in Côte d'Ivoire for so long, it had access to media that the other parties did not have. Similarly, this party had

\footnotetext{
${ }^{28}$ Mundt, p. 190.

${ }^{29}$ Widner, "The 1990 Elections in Côte d'Ivoire," p. 32.

${ }^{30}$ Widner, "The 1990 Elections in Côte d'Ivoire," p. 33.

${ }^{31}$ Widner, "The 1990 Elections in Côte d'Ivoire," p. 35.
} 
access to public places to hold gatherings and rallies. In addition, le Vieux wanted to be remembered as more than just another African leader who would not give up power. Holding these elections would hopefully allow him to be viewed differently by the citizens of the country and of the world in this new international order.

With all the focus placed on the new political openness in the country, little attention was actually focused on the country's serious economic problems during the next several months. Houphouet-Boigny did name Alassane Ouattara as the leader of the Interministerial council he put together to work out a plan to deal with the critical situation. Ouattara's professional background as the former Director of the Africa Division at the International Monetary Fund is a clear indication of the depth of the Ivoirian crisis. However, difficult economic policy changes would not be put into effect until after the elections for mostly political reasons.

Between May and November 1990, much time was spent authorizing political parties and little time was allotted for actual campaigning. Thanks to the advantages of the PDCI in the political field, no party or candidate managed to pose a serious threat to Houphouet-Boigny. Le Vieux easily won the November 1990 elections with 81.7 per cent of the votes. ${ }^{32}$ His party also handily won the legislative and municipal elections. In the legislative elections, 163 seats out of 175 went to the PDCI; the few remaining seats being shared among the Front Populaire Ivoirien (Ivoirian Popular Front, FPI) with nine seats, the Parti Ivoirien du Travail (Ivoirian Labor Party, PIT) with one seat and two

\footnotetext{
${ }^{32}$ Mundt, p. 191.
} 
independent with two seats. ${ }^{33}$ The PDCI also won the municipal elections with 123

towns, leaving only six municipalities to the FPI and three others to independent lists. ${ }^{34}$

With the elections behind them and a renewed mandate to lead the country, President Felix Houphouet-Boigny and his party and government leaders were able to switch their focus back to the serious economic issues facing the country as a whole and the agricultural sector in particular.

\section{No New International Coffee Agreement:}

\section{$\underline{\text { Ivoirian State and Farmers Seek Real Solutions }}$}

(November 1990 - December 1993)

Because Felix Houphouet-Boigny realized the seriousness of the Ivoirian economic and financial situation, he decided to make the newcomer in his government a more permanent participant. He named Alassane Ouattara as his new Premier Ministre on November 7, 1990. Since Côte d'Ivoire would need the aid of the international financial institutions to get out of its economic and financial crisis, why not have a prime minister who has personal and professional contacts with these key world financial institutions and its leaders?

Houphouet-Boigny may also have brought in Alassane Ouattara because, although Ivoirian, he is not a party insider. Since the reforms to be made would undoubtedly be

${ }^{33}$ Yves Fauré, "L'économie politique d'une démocratisation: Eléments d'analyse à propos de l'expérience récente de la Côte d'Ivoire," Politique Africaine, 43 (October 1991), pp. 31-49, p. 35.

${ }^{34}$ Fauré, p. 35. 
unpopular with many segments of the Ivoirian population, why not have someone head the reforms who is not quite so closely affiliated with the party in power? In this fashion, the reforms would not reflect quite so badly on the PDCI itself. Making Ouattara a scapegoat could be positive for the PDCI in this new, competitive political environment.

The incoming government needed to seriously restructure the Ivoirian economy to move it forward. With support from the international financial institutions, this cabinet put together a coherent policy to deal with the economy and the agricultural sector in particular. The Ouattara Plan outlined four principal areas for reform: "re-organisation of public and parastatal companies; the privatisation of public enterprises; the improvement of public finance, and debt restructuring." 35 These broad objectives would be pursued and adapted in various ways for the country's diverse economic sectors.

For the coffee and cocoa sectors specifically, the Ouattara Plan had three primary purposes. ${ }^{36}$ The most interesting objective for the purpose of this dissertation was the proposed liberalization of the coffee marketing system. In particular, the Caisse's intervention abilities would be reduced. Its management was to open up to the diversity of the sector's professionals and the different monopolies and monopsonies would be eliminated.

${ }^{35}$ Aribisala, p. 135.

36 "Agro-industries: des filières face au défi de la compétitivité," Marchés Tropicaux et Méditeraanéens, July 2, 1993, pp. 1696-1703, p. 1696. 
It is during the first few months of his government that Ouattara modified the

Caisse de Stabilisation and its functioning. In an interview given to Jeune Afrique in mid1991, he stated regarding the Caisse:

It has been "resized." It now only works with coffee and cocoa. That is already important. In the past, the Caisse did everything and anything. For example, it was not responsible for sugar production but it commercialized it. It intervened for cotton or palm oil. All of that is finished. Second element: the decision-making committee of the Caisse did not take into account all the parties in the sector. Now the commercial banks, the Central Bank, the exporters, the producers and all those who are in the sector will be part of the board of directors. The opinions of all will be taken into account. ${ }^{37}$

The responsibilities of this central agency in the country's agricultural element were changed and production liberalized. ${ }^{38}$ First, the system of guaranteed producer prices which had been the cornerstone of Ivoirian coffee and cocoa production and of the Caisse's existence was eliminated and officially replaced by three non-binding reference prices: one for the coffee beans purchased directly in the farmers' fields, one for the storage value, and one minimum guaranteed price based on anticipated sales and market prices. ${ }^{39}$ For several years, producers and exporters continued to use these reference prices as set prices. Second, the Caisse was no longer to control the transport segment or the export sales in the coffee trade. The export quotas in effect for the exporters of the Ivoirian coffee were eliminated. This obliged in the private exporters to get more involved in the actual harvesting of coffee. They had to travel to the farms to buy the coffee and

37 "Interview: Alassane Ouattara," Jeune Afrique, May 15- 21, 1991, p. 110.

38 "Agro-industries: des filières face au défi de la compétitivité," p. 1699.

${ }^{39}$ Agro-industries: des filières face au défi de la compétitivité," p. 1696. 
transport it. The Caisse did remain in charge of several other key parts of the coffee sector: approval of exporters, export quality control and the management of the Stabilization Fund. ${ }^{40}$

The second objective of the new government with regard to the coffee sector involved the decrease of product marketing costs. ${ }^{41}$ This involved in part the abandoning of the fixed price systems and especially producer prices, as already discussed. The price of coffee was further reduced during the $1992-1993$ season to $60 \mathrm{CFA}$ francs. ${ }^{42}$ In addition, however, domestic transport costs were fixed; the duration and costs of storage were cut. The coffee sold to exporters needed to be carefully scrutinized for bad beans and other undesired particles as many old coffee trees were still in production. Ivoirian coffee farmers were also called upon to diversify their crops quickly to diffuse the impact of this major crisis. ${ }^{43}$ The combination of all these factors working to decrease the crop production costs had the rapid effect of negatively affecting Ivoirian coffee quality. The quality of the Ivoirian crop in the $1990 / 1991$ season was particularly terrible. ${ }^{44}$

${ }^{40}$ Bertrand Laporte, Les Réformes des Systèmes de Commercialisation Et De Stabilisation des Filières Café et Cacao au Cameroun et en Côte d'Ivoire (Paris, France: Ministère de la Coopération et Du Développement, 1992).

41 "Agro-industries: des filières face au défi de la compétitivité," p. 1699.

42 "Agro-industries: des filières face au défi de la compétitivité," p. 1699.

${ }^{43}$ Economist Intelligence Unit, EIU Country Profile 1993/94 Côte d'Ivoire Mali (London, United Kingdom, 1994), p. 15.

${ }^{44}$ Moise Koffi Koumoue, Politique Economique et Ajustement Structurel en Côte d'Ivoire (Paris, France: Editions L'Harmattan, 1994), p. 19. 
In addition, the industrial monopoly on the hulling of coffee was eliminated during the 1991-1992 season, allowing and encouraging producers and the cooperatives to get involved in this step of the coffee production process. Prices then had to be differentiated based on whether the coffee had been hulled or not. Financing was made available to the cooperatives to give them the means necessary for their investment in the hulling, as in the collection, storage and transport of the beans.

The third overall goal for the Ivoirian economy was the financial equilibrium of each sector, independently from the other sectors. ${ }^{45}$ This could not really be done until the individual sectors of the economy could be made financially solvent. The coffee sector, for example, was obviously not be self-sufficient in 1990 and would take some time to become economically independent. Starting in 1992-93 the sector was on its way to meet that goal. ${ }^{46}$

For the World Bank and the IMF, the Ivoirian adjustment effort in general was slow and difficult for several reasons: the severity of the successive external shocks to the economy and the distortion of the national economy by the use of the pegged CFA Franc. In addition, the government has been reluctant to "take the need for adjustment seriously and to identify itself with the adjustment programs supported by the World Bank." ${ }^{47}$

45 “Agro-industries: des filières face au défi de la compétitivité," p. 1701.

46 “Agro-industries: des filières face au défi de la compétitivité," p. 1701.

${ }^{47}$ Lionel Demery, "Côte d'Ivoire: Fettered Adjustment," in Ishrat Husain and Rashid Faruqee (eds.), Adjustment in Africa: Lessons from Country Case Studies (Washington, DC: World Bank, 1996), pp. 72-152, p. 73. 
It is true that the three objectives detailed above as carried out by Ouattara's government and supported and pushed by the international financial institutions attacked the very core and structure of the Ivoirian economic system which had been patiently built over many years by those in power in Côte d'Ivoire. ${ }^{48}$ This overhaul of the system itself would affect the individual players involved as well. The President's own fears about the liberalization of the economy resulted in his procrastination. ${ }^{49}$ The negotiations and action on the reforms were always slow. ${ }^{50}$ He agreed to cut the producer price of coffee in half in late 1989 because he had no other option. The very production system he had built was in jeopardy of being eliminated and he could not watch that take place. It became clear that he was willing to sacrifice the producers he considered so key for the system he had built.

In some instances, reforms agreed upon by the World Bank and IMF were not enacted quite in the way in which they were supposed to be. The Caistab, for instance, has not intervened officially in internal commercialization since 1991. However, it is still very involved in the marketing of the beans as the reference prices were still being used by traders and producers at set prices. ${ }^{51}$

Overall, the coffee farmers did not fair well through the prolonged crisis. The extremely low producer prices of coffee brought social and economic crisis to the rural
${ }^{48}$ Losch, p. 224.
${ }^{49}$ Losch, p. 224.
${ }^{50}$ Losch, p. 224.
${ }^{51}$ Laporte, p. 72. 
areas of Southern Côte d'Ivoire, as well as a growing disinterest for coffee among some of its producers, and significant consequences for the maintenance of the fields. ${ }^{52}$ Small farmers no longer had the means to pay for the workers needed for the maintenance and harvest of the labor-intensive crop. As a result, they removed their children from school and employed them on the coffee plantations..$^{53}$

The liberalization of the coffee hulling process did allow some unemployed wage laborers to find work in the manual decortication process. ${ }^{54}$ They were able to earn up to 44 CFA Francs per kilogram by hulling and proved themselves to be resilient and flexible by adapting quickly to the new circumstances.

About a third of coffee producers increased the diversity of their crops to raise their income. ${ }^{55}$ The preferred options included: planting cassava or rubber, harvesting wild kola, and expanding the fishing. The pursuit of these possibilities was of a temporary nature.

Beyond trying to survive, the farmers were seeking new ways to express their opinions and make their voices heard. The new more open, multi-party politics in Côte d'Ivoire allowed the farmers to create their own unions in mid-1991. This was the first time in Ivoirian history that these types of organizations were allowed, regardless of who sponsored them. Peasants wanted their voices to be heard through channels other than

\footnotetext{
52 "Agro-industries: des filières face au défil de la compétitivité," p. 1702.

53 "Agro-industries: des filières face au défi de la compétitivité," p. 1702.

54 "Agro-industries: des filières face au défil de la compétitivité," p. 1702.

${ }^{55}$ Widner, "The Discovery of Politics," p. 303.
} 
state-created cooperatives and organizations. In July 1991, a union entitled the Syndicat des Agriculteurs de Côte d'Ivoire (Union of Farmers of Côte d'Ivoire, SYNAGGI) was formed and held its first Congress. Farmers were finally speaking out. ${ }^{56}$ One of the main points made by this new group was that "their incomes need not have declined so if government had invested funds from cocoa, coffee and cotton sales more wisely." ${ }^{57} \mathrm{I}$ agree that the Ivoirian government did squander much of the Caisse's profits in projects that did not subsequently contribute to economic development.

According to Affou, the following is the list of the demands put forth by SYNAGGI and its sister cooperative (COOPAGI) which was created alongside it:

the representation of producers on the board of the Caisse, the representation of producers in the Chamber of Agriculture, the exclusion of non-producers from the internal commercialization of coffee and cocoa, the release of export quotas primarily to agricultural cooperatives and producers, the official involvement of groups of producers in the fight against fraud at the borders..., the right to participate in the domestic marketing of cotton in the Northern Savannah, a price increase for agricultural products, the opening of the annual campaign prior to the start of the school year (so that the producers can be better prepared financially for the return of their kids to school) ${ }^{58}$

From this list, we can see that the farmers sought input and participation in the processes and decisions involving them and their livelihood as well as more monetary compensation

${ }^{56}$ Widner, "The Discovery of Politics," p. 323.

${ }^{57}$ Widner, "The Discovery of Politics," p. 325.

${ }^{58}$ Simplice Yapi Affou, "Renforcement des organisations paysannes et progrés agricole: obstacles ou atouts pour le progrés agricole," in Bernard Contamin and Harris Memel Fotê (eds.), Le modèle ivoirien en questions: crises, ajustements, recompositions (Paris, France: Editions Karthala, 1997), pp. 555-571, p. 567. 
for their crops. Up to this point, coffee producers had not had the opportunity to voice specifically their perspectives. Ivoirian rural society was waking up and speaking out.

In addition to voicing the concerns and opinions of the farmers, these new organizations were trying to lay claim to the regional resources left behind by the Caisse in their efforts to help the producers and their families. ${ }^{59}$ As the Caisse moved out of the countryside, it left behind buildings, equipment, etc.. SYNAGGI wanted to lay claim to these items which could be very useful to its members.

SYNAGGI and COOPAGI were sponsored and supported by the primary opposition party in Côte d'Ivoire, the Front Populaire Ivorien (Popular Ivoirian Front, FPI). In response, the PDCI created its own partisan agricultural unions. These are: Union National des Agriculteurs de Côte d'Ivoire (National Union of Farmers of Côte d'Ivoire, UNACI) and Union Régionale des entreprises coopératives des savanes de Côte d'Ivoire (Regional Union of Cooperative Enterprises of the Savannas of Côte d'Ivoire, URECOSI). The latter one is primarily a regional cooperative pushing for the marketing of cotton in the Northern part of the country.

One of the key questions is: were the growers and their new representative organizations heard by those who until then decided their fate? For Colin and Losch, after three decades of consistent state intervention, it was time to render coffee producers partners in their own sector. ${ }^{60}$ Colin and Losch believe that there needed to be less control

${ }^{59}$ Dwayne Woods, "The politics of organizing the countryside: rural cooperatives in Côte d'Ivoire, The Journal of Modern African Studies, 37, 3 (1999), pp. 489-506, p. 503.

${ }^{60}$ Jean- Philippe Colin and Bruno Losch, "Touche pas à mon planteur: Réflexions sur les encadrements paysans à travers quelques exemples ivoiriens," Politique Africaine, 40 
and more assistance for the producers. This would involve more information, training, and counsel for the farmers. We will explore this issue further in the next section of this chapter.

At the beginning of 1993, the Ivoirian state announced that it would increase the reference prices up to 170 CFA francs a kilo for the 1993/94 season. This was the first price increase since the beginning of the crisis. The Caisse and its reference prices were bringing a level of stability to the sector that no one was prepared to do without. ${ }^{61}$

Also at the beginning of this $93-94$ harvest season, the Ouattara government entrusted the domestic commercialization of coffee and cocoa exclusively to the cooperatives, attempting to take out the middlemen. ${ }^{62}$ Private exporters were quite unhappy about this turn of events and immediately stopped purchasing from the GVCs and transporting coffee within the country. This forced the government to return to prior practices in which the traders and not the communities earned the profits from crop production. According to Losch, it is however indicative of an important fact: the cooperatives had not moved ahead in their position in the production system. ${ }^{63}$ They have only been able to handle approximately twenty per cent of total Ivoirian coffee crop. ${ }^{64}$ They did not have access to export and they could not emancipate themselves financially

(December 1990), pp. 83-99, p. 98.

61 "Agro-industries: des filières face au défi de la compétitivité," p. 1703.

${ }^{62}$ Losch, "A la recherche du chainon manquant," p. 226.

${ }^{63}$ Losch, "A la recherche du chainon manquant," p. 226.

${ }^{64}$ EIU Country Profile 1994/95 Côte d'Ivoire Mali, p. 16. 
and technically. One of the questions for the next section of this chapter might be: can the newly created farmers' organizations take on some of the responsibilities that the GVCs can obviously not take on or that the Caisse has given up?

Not surprisingly, as a result of the impressive decrease on the prices of coffee and cocoa over the years and the general malaise of the Ivoirian economy, the Structural Adjustment Plans designed for Côte d'Ivoire for the years 1987 to 1993 were a complete disaster. ${ }^{65}$ The country was in a terrible financial position. Between 1989 and 1993, the GDP per capita decreased by 15 per cent. External debt had risen from 141 per cent to 210 per cent of GDP between 1989 and $1993 .{ }^{66}$ Coffee production was also in continuous decline for three production years from 1990 to 1993. Extreme poverty in Côte d'Ivoire went up from 11 per cent in 1985 to 31 per cent in $1993 .{ }^{67}$ Côte d'Ivoire fell to the fifth rank of coffee production in the world, after having been third for more than 25 years.

Although it was obvious that economic reforms had been under way in the Côte d'Ivoire for a number of years, the pace of real change in the country's actual situation was quite slow. The President and his government were heavily criticized in 1992 and there was some discussion as to what he should do. ${ }^{68}$ The President took a step back from the reforms of his Prime Minister without actually removing him from office. He also

${ }^{65}$ Jeune Afrique Plus: La Côte d'Ivoire: Eveil d'un éléphant," Jeune Afrique, 1818 (1996), pp. 79-134, p. 97.

${ }^{66}$ Naiman and Watkins, p. 11

${ }^{67}$ Côte d'Ivoire: Revue de L'Aide de la Banque Mondiale, p. 7.

${ }^{68}$ Frédéric Dorce, Géraldine Faes and Augustin Thiam, "Cinq scénarios pour Houphouet," Jeune Afrique, July 23-29, 1992, pp. 16-19. 
indicated through legal maneuvers who his successor should be, namely the President of the National Assembly Henri Konan Bédié. Houphouet-Boigny chose to let Ouattara continue the economic reforms and decided not to resign despite his advancing age and apparent illness. The country seemed to be waiting.

After several months of resting in France, President Felix Houphouet-Boigny returned to his nation and died in Yamoussoukro, Côte d'Ivoire on December 7, 1993.

\section{Unregulated World Coffee Markets:}

\section{Moving Beyond The Agricultural Crisis and Dealing With New Variables}

\section{$\underline{\text { January } 1994 \text { - January } 1999}$}

Houphouet-Boigny's death was immediately followed by another key change in West African politics, namely the devaluation of the CFA Franc in January 1994. Encouraged by the World Bank and the International Monetary Fund as well as its European counterparts, France had finally agreed to a 50 per cent devaluation of the CFA franc. With the forthcoming creation of a European currency in the Euro, the devaluation of the CFA franc had become almost a necessity. One French franc would now be worth 100 CFA francs instead of 50. This would have a significant impact on the region's economies. According to Mundt, "some in Africa argued wistfully that it would never have happened if Houphouet were alive, and the timing of the decision was hardly coincidental: Mitterrand and Balladur used the gathering of leaders at the funeral to announce France's next steps." ${ }^{16}$

${ }^{69}$ Mundt, p. 193. 
Devaluation is an interesting instrument of monetary policy as it affects all segments of society equally without regard for economic status, ethnicity, or political affiliation. ${ }^{70}$ The various sectors of the Ivoirian economy were thus all affected by the monetary adjustment.

The combination of fundamental changes affecting Côte d'Ivoire not only terminated the political stability the country had known for much of its independent history, it also brought an end to the economic reform policies of the Ouattara government. After heated discussions throughout the country as to who should succeed Le Vieux, Henri Konan Bédié took over as President of Côte d'Ivoire. He and his new government did not intend to continue the policies of the previous government in many sectors of the economy. This resulted in mixed messages being sent in particular to the coffee sector, and its farmers who were not sure in which direction to head.

The coffee sector in Côte d'Ivoire is at the center of an interesting paradox. The Ivoirian economy experienced a severe crisis because of its dependence on coffee and cocoa and the collapse of the coffee and cocoa agreements. Reforms were made during the previous three years to rectify the dependence of the state and the country on the key export crops. However, in order to get out of the crisis and move on, the Ivoirian economy still needed the contribution of the coffee and cocoa sectors. The IMF and the World Bank were prepared to help Côte d'Ivoire following the CFA Franc's devaluation.

${ }^{70}$ Bruno Losch, "Les agro-exportateurs face à la dévaluation," Politique Africaine 54 (June 1994), pp. 88-103, p. 89. 
In the Ivoirian Structural Adjusment Plan put in place for the years 1994 to 1997, the IMF had three specific objectives: "to generate a primary budget surplus of three per cent ...; to finance debt service; to attain GDP growth of five per cent by 1995 ; and to protect the most vulnerable during adjustment." ${ }^{, 71}$ During this Structural Adjustment Plan, according to the World Bank, Côte d'Ivoire benefitted from positive economic circumstances. The World Bank released $\$ 469$ million to Côte d'Ivoire in February 1994, just after the devaluation of the CFA Franc. In addition, world commodity prices and Ivoirian oil production increased in 1994 and 1995.

Considering the significant changes at the national and local levels in Côte d'Ivoire between 1990 and 1994, what was the continuing path of state-society relations? What were the state policies towards the coffee sector and the farmers? How did the newlycreated producer associations interact with the state? Where was the Caisse in this relationship and what was its path through these times?

The new state leaders recognized the bureaucratic nature of the state's role in agriculture. According to the Ministry of Planning in its publication Côte d'Ivoire 2000, "the role of the state with regards to agriculture will be totally transformed: from producer and omnipresent and sometimes bureaucratic promoter, the state would see its role diminished to one of support and accompaniment, which is its role vis-a-vis the other economic sectors."72

${ }^{71}$ Naiman and Watkins, p. 11.

${ }^{72}$ Ministère du Plan, Côte d'Ivoire 2000 (Abidjan, Côte d'Ivoire: Editions Neter, 1994), p. 26. 
Despite this statement of change with regard to the state's position in agriculture, coffee was still a priority for the new leaders. They were intent on maintaining Ivoirian leadership of Robusta coffee production and wanted to regain the rank of third producer of the commodity in the world. ${ }^{73}$ This meant a significant increase in the country's small production of 1993-94,140,000. tons of coffee. ${ }^{74}$ The goal for the government was 300,000 tons annually as had been the case in the 1980 's. In order to reach these objectives, emphasis was placed on rejuvenating the coffee trees, digging up bad trees and replanting trees in more favorable production areas, extending coffee production to ecologically favorable areas, and improving the quality problems of Ivoirian coffee. ${ }^{75}$ This was a return to previous government policies.

According to Alain Gauze, Ivoirian Minister of Raw Materials, the future of Ivoirian coffee lies in its ability to get a piece of the world processing market and thus move up the production chain. Gauze argued that with the liberalization of the Soviet Union and Eastern Europe, there was an increasing need for instant coffee as well as raw berries. $^{76}$ This policy choice allowed the country to be less dependent on the world market prices for unprocessed coffee and provide the country some of the profits that are made at the processing level.

${ }^{73}$ Koumoue, p. 98.

${ }^{74}$ Interview with Mr. Yapou, Bureau National d'Etudes Techniques et de Développement, July 7, 1997.

${ }^{75}$ Koumoue, p. 98.

76 "Côte d'Ivoire: Eveil d'Un Eléphant," p. 127. 
Although the government seemed quite interested in the strengthening of the coffee sector as a whole and in a significant increase in coffee production, it also took measures which seemed to distance the state and the country from coffee. First, it modified the very institution that was designed to provide coffee farmers with technical assistance, the SATMACI, as part of the overall liberalization of the Ivoirian economy. Prior to this change, there had been three technical assistance agencies in the country: the SATMACI, the Compagnie Ivoirienne pour le Développement des Cultures Vivriéres (Ivoirian Agency for the Development of Food Crops,CIDV) which worked with producers of food crops and the Société pour le Développement de la Production Animale (Agency for the Development of Animal Resources, SODEPRA) which dealt with animal breeding. These three were combined into one state agency for technical assistance, the Agence Nationale d'Appui au Développement Rural (National Agency for Assistance to Rural Development, ANADER). The idea behind this change was that there were too many different people providing technical assistance to the various groups, creating overlap in the technical services provided. In addition, these extension services had apparently been too expensive and not efficient enough.

The government also moved away from viewing the GVCs as a solution to the problems of the Ivoirian countryside. "The GVCs were unable to mobilize the resources needed to help rural producers deal with the growing pressure on their incomes and the refusal by traders to extend credit to peasants. ${ }^{177}$ They were pretty much disbanded as a

77 Woods, p. 495. 
result of their lack of resources and the push by the IMF and the World Bank to get the state out of the countryside.

In addition, the government continued to pursue agricultural diversification as a development goal. It pursued this alternative in an attempt to move away from the extreme dependence of the country on coffee and cocoa. ${ }^{78}$ It continued to promote the export of timber, cotton, rubber, pineapple, among others even though it had not had much success with its efforts until then. The sales of these other crops also depend on world prices and not on local prices.

What was the situation in the coffee- and cocoa-growing areas following the devaluation of the CFA franc and the new government's policies? Poverty had continued to grow in rural areas. With the low prices of coffee, the purchasing power of the producers had decreased 30 per cent. ${ }^{79}$ Coffee producers faced a number of issues with regard to their crop: the age of their trees and the poverty of the soil, in particular. They did not have the financial means to increase their yields by purchasing fertilizer or hiring laborers to tend to the crops more. According to Jeune Afrique, the poor situation of the farmers had even forced them to grow coffee in illegal places, such as classified forests. ${ }^{80}$ They systematically cleared some of these forests in an attempt to increase their harvest and thus their incomes.

${ }^{78}$ Koumoue, p. 38.

79 "La campagne a mal à l'Etat," Jeune Afrique, November 9-15, 1995, pp. 124-129, p. 124.

80 "La campagne a mal à l'Etat," p. 125. 
A few weeks after the devaluation of the CFA Franc in January 1994, the domestic price of coffee was actually raised to 220 CFA Francs per kilogram from 170 CFA Francs. ${ }^{81}$ This actually began an upward swing for coffee prices. Between October 1993 and February 1995, the producer price of coffee almost quadrupled; it went up from 140 CFA francs per kilogram to 530 CFA francs. ${ }^{82}$

This price increase at the local level and at the international level is a source of irony: it gave the very economic system the international financial institutions were trying to eliminate some additional breathing space. ${ }^{83}$ The devaluation of the CFA franc and the increase in prices across the board provided the Ivoirian coffee sector with more income starting in 1994. This positive turnaround in coffee prices relieved the struggling producers and the Caisse.

As a result of the higher prices, the government encouraged even more coffee production. President Bédié and his colleagues wanted coffee growers to produce more coffee and farmers who were no longer growing coffee to return to it. They were prepared to offer financial incentives to reach their national goal of 300,000 tons of coffee per year. To that effect, they had set aside three billion CFA francs. ${ }^{84}$ Of particular concern to the government was the quality of Ivoirian coffee and the productivity of the

\footnotetext{
${ }^{81}$ Country Profile 94/95, p. 17-18.
}

82 "Alain Gauze: 'Nous sommes trop dépendants du café et du cacao'," Jeune Afrique, February 2-8, 1995, pp. 46-47, p. 47.
${ }^{83}$ Losch, "A la recherche du chainon manquant," p. 225.
${ }^{84}$ Hien Solo, "La relance, désormais certaine," Fraternité Matin, September 9, 1994, p. 2. 
fields. ${ }^{85}$ To increase both, the government would make funds available to the agricultural unions, the remaining GVCs and individual producers for the cleaning (weeding) of fields and fertilizers. Despite all of Côte d'Ivoire's recent problems, the government still viewed coffee as a key to the economic development of the country.

Despite the breathing space given to the coffee sector, its structures and producers, Bédié's yielded to IMF pressure and began the privatization of the Caisse de Stabilisation. ${ }^{86}$ The Caisse's purchasing centers which were supposed to control sales transactions and reduce fraud were eliminated. Exporters were to manage coffee transport on an individual basis. In addition, the buyers were from this point on to be chosen by the exporters themselves and not the Caisse.

The International Monetary Fund was quite pleased with the general direction of the Ivoirian economy and its reforms as it continued to disburse loans and financial assistance to the government. In May 1995, for example, it approved an Annual Loan for Côte d'Ivoire to assist the government in its reform effort. ${ }^{87}$ In March 1998, the IMF and the World Bank approved an Ivoirian debt reduction package which would decrease its national debt by $\$ 345$ million. $^{88}$

${ }^{85}$ Hien Solo, "Producteurs, les crédits de campagne sont là," Fraternité Matin, August 10, 1994, p. 5.

${ }^{86}$ Hien Solo, "La Stabilisation des Prix Maintenue," Fraternité Matin, September 17, 1995, p. 6.

${ }^{87}$ International Monetary Fund, Press Release: No. 95/30, "IMF Approves Second Annual Loan Under the ESAF," May 22, 1995.

${ }^{88}$ International Monetary Fund, Press Release No. 98/16885 "World Bank and IMF Approve Debt Reduction Package for Côte d'Ivoire," March 19, 1998. 
According to Yapou, the West and particularly the international financial

institutions were obsessed with the Caisse as the main problem in Côte d'Ivoire's overall economy. ${ }^{89}$ When interviewed in 1997 , he stated that the Caisse needed to have less control and needed to be more transparent. However, he, the Managing Director of the Caistab and the Minister of Agriculture did not believe that it should disappear. The Minister of Agriculture at that time, Lambert Kouassi Konan, was particularly vehement. He stated:

As to the Caistab, we have accepted to modify its role by closing the purchase centers and increasing its transparence by introducing a daily electronic price auction. The World Bank would like to completely dismantle the Caisse but we do not intend to suffer the same fate as Cameroon or Ghana where the sectors are in a state of weightlessness since the "boards" were removed..$^{90}$

His fear was that a total privatization of the Caisse will go too far and create chaos for an agricultural sector which is not ready for it. Konan believed that the producers should be organized and educated before such a privatization could take place. ${ }^{91}$ He claimed to believe that this type of education is a slow process.

It is true that the producers are more independent in the production and marketing of their coffee. According to Kouassi, "the peasant no longer sees the Caisse in the

${ }^{89}$ Interview of Mr. Yapou, Bureau d'Etudes Techniques et de Développement, Abidjan, Côte d'Ivoire, July 7, 1997.

90 "La campagne a mal à l'Etat," pp. 128-129.

${ }^{91}$ Assou Massou, "Oui à la libéralisation, mais à notre rythme!," Jeune Afrique, August 6-12, 1997, pp. 82-84, p. 83. 
countryside." ${ }^{12}$ To sell his coffee, the producer can either sell it to middleman who comes to his field or sell it to one of the unions. In the latter case, he has to transport it. Nevertheless, it is clear to many that the producers either need to organize on their own or let themselves be organized. Opinions vary as to how this should happen. Cisse Locine created the Federation ivoirienne de cafe et de cacao and would like for it be an organization similar to the Federacion Nacional de Cafeteros de Colombia. ${ }^{93}$ Yapou also believed that the producers need to be organized as they were in Colombia. Bouadou Kouame, however, believes that a federation of cooperatives is better suited to the Ivoirian peasants. He argues that the farmers need more education and resources in order to be a Federation.

On September 12, 1997, the General Manager of the Caisse, M. Yves Kouassi, announced that the Caisse de Stabilisation would be privatized. According to him, "it will not disappear, it will transform itself and its missions will change... The state will maintain minority interest in the new structure to be created."94 The actual privatization was to take place in January 1999. Following a delay of four months, the change finally occurred on April 29, 1999. The mission of the new private board was to forecast coffee and cocoa production and collect information on export volume and earnings and port deliveries. ${ }^{95}$

\footnotetext{
${ }^{92}$ Interview of Mrs. Kouassi, Manager for Coffee, Caisse de Stabilisation, July 10, 1997.

${ }_{93}$ Woods, p. 504.

94 "La Caistab sera privatisée, selon M. Kouassi," Marchés Tropicaux et Méditerranéens, September 19, 1997, p. 2055.

${ }^{95}$ Africa News Service, "Côte d'Ivoire's Commodity Board Privatised," May 4, 1999.
} 
It is obvious that the World Bank and the IMF played an important part in this key event in the Ivoirian coffee sector. Convincing the Ivoirian leaders to take this radical step was surely not easy. However, the aid promised and delivered to Côte d'Ivoire year after year surely helped to sway the government. Tensions and miscommunications definitely existed between the IMF and the Bédié government on the issue of the Caisse. The IMF even accused the Ivoirian state of concealing information needed by the IMF in March 1999. ${ }^{96}$ The World Bank stated that this privatization would enable farmers to get the prices they deserve and allow more transparency in the coffee sector. The World Bank even recognized the sometimes tenuous tactics of the Caisse over the years. One of the World Bank officials involved in the privatization of the Caisse stated: "the Caisse stabilizes prices of cash crops when the market flops." ${ }^{.97}$

As a private entity, the Caisse was now able to advertise for itself. The agency took out a four- page ad in Jeune Afrique.$^{98}$ In these pages, the Caisse outlined its historical role in the Ivory Coast, its mission, the dangers of liberalization and the road to follow. The ad ends by letting the reader know what remains on its agenda: "the constitution of databases of information on the coffee and cocoa sectors, the strengthening of the exporters, the redefinition of the agreements with exporters with the goal of "ivoirizing" exports, the revision of rural taxation, financing, ..."99

${ }^{96}$ Africa News Service, "Côte d'Ivoire at Loggerheads with IMF,” March 2, 1999.

97 "Côte d'Ivoire's Commodity Board Privatized," May 4, 1999.

98 "Caistab: Un Garant de la Paix Sociale," Jeune Afrique, October 15-28, 1997, pp. 167-170.

99 "Caistab: Un Garant de la Paix Sociale," p. 170. 
The elimination of the Caisse de Stabilisation from the Ivoirian agricultural scene marks the end of an era in Ivoirian coffee and cocoa production. The state and its leaders no longer benefit directly from its profits. The producers receive crop prices that reflect more closely world market values and are more autonomous in their production and distribution of coffee. The deletion of the Caisse from state-society relations in the Ivoirian coffee sector opens the sector up for new voices to participate more fully in the political economy. The state is disengaging. Is society engaging?

The associations which came about as a result of multi-party politics must deal with a large number of issues facing the producers such as deforestation, stagnant coffee and cocoa prices, high prices for pesticides and other inputs, and the consequences of liberalization. For Woods, "to tackle these combined problems, independent rural associations will have to succeed where the state failed, - that is in organizing cocoa, coffee and cotton producers into vibrant rural cooperatives. So far, they have introduced more choice into the countryside, but it remains to be seen whether or not they will be able to create the kinds vibrant rural associations that are needed." ${ }^{100}$

\section{$\underline{\text { Conclusions }}$}

In this chapter, I discussed the significant changes that took place in the Ivoirian coffee sector after 1989. I looked at the policy changes made by the state over the period with regard to the producers and the Caisse. I also reviewed developments on the side of the farmers, namely their changing perspectives on the crisis and the results.

\footnotetext{
100 Woods, p. 504.
} 
It is quite obvious from this lengthy discussion that the peasants were not particularly involved in the liberalization of the coffee sector and the privatization of the Caisse. The numerous changes were definitely made by the state but were in large part encouraged or required by the presence of the World Bank and the International Monetary Fund. These two international organizations were able to keep Côte d'Ivoire afloat economically through and beyond its difficult crisis. As the decade progressed, the country continued to need the assistance of the international financial institutions and had to comply with most elements of their liberalization programs. Houphouet-Boigny and Bédié's governments argued with their international creditors at certain points but it had to make some concessions in order to receive continued funding.

During this time, coffee growers were primarily concerned with their economic survival. They did begin the hopeful process of organizing on their own, independently from the state and from the GVCs. At the end of the 1990's, these new associations began to act on behalf of their members. For example, they planned a sit-down protest in February 1999 to voice their fears and concerns. Part of the problem for these non-state organizations was the lack of resources, financial and otherwise. They did not have the funding to forward their agenda and take on a more active role in the evolution of their livelihoods. They also did not succeed in obtaining use of the Caisse's equipment and facilities in the countryside. These organizations thus came about as a result of turbulent times for the farmers but are just now beginning to act on behalf of their constituents.

In terms of Bratton's framework, how does Côte d'Ivoire fit in? Prior to 1989, I would argue that the state was quite engaged vis-a-vis society, trying to mobilize them to 
produce as much coffee and cocoa as possible. The farmers were quite disengaged as they did not trust the state and its parastatal entities. The crisis which started prior to 1989 and really culminated with the collapse of the International Coffee Agreement brought about changes in the state-society dynamics of the Ivorian coffee sector. Pushed by the IMF and the World Bank to get out of the countryside, the state and its agency, the Caisse, became less of a presence in the rural areas and because of its lack of means, it had less say in what was happening there. With farmer unions forming in 1991, the producers started to organize. Ivoirian society as a whole was becoming more open and the farmers were no exception.

In my opinion, the disappearance of the Caisse from the agricultural scene was in large part the result of the lack of mutual engagement by the state and Ivoirian society. The producers were not involved in the creation of the parastatal or its policy choices over the years. They were not attached to it as a fixture of the Ivoirian coutryside. On the contrary, they may have had an interest in its elimination although they never specifically protested to that end. I believe that the absence of any farmer support for the Caisse is a key reason for its privatization. The World Bank and the IMF were able to pressure the Ivoirian government to privatize the Caisse in part because the farmers were not on the same side as the Caisse.

The next few years will be key for state-society relations in the Ivoirian coffee sector as the producers adapt to the void left by the Caisse and participate more actively in their own future. It is unclear yet how the new national political developments in Côte d'Ivoire will affect coffee production and state-farmer relations. 


\title{
CHAPTER VIII
}

\section{COMPARATIVE ANALYSIS:}

\section{COLOMBIA, COTE D'IVOIRE, AND OTHER COFFEE-PRODUCING COUNTRIES}

\begin{abstract}
All coffee-producing countries and producers around the world were affected in some way by the collapse of the International Coffee Agreement in 1989. They all faced very low prices for their coffee beans and the national consequences of these depressed prices. Although the experiences of individual countries differ in the details, there are general trends that are worth identifying. These include the economic and social difficulties resulting from the changes in world coffee prices, the transformation or elimination of national coffee parastatals, as well as the state policies enacted in response to the modified international rules.

This chapter will begin by bringing together the two primary case studies of this dissertation, Colombia and Côte d'Ivoire, and analyzing the similarities and differences noted in those two countries at the various relevant levels of analysis. In the subsequent section, I will describe and analyze events in a few additional coffee-producing countries in an attempt to enrich this comparative study and draw broader conclusions from it.
\end{abstract}


As two countries facing the consequences of the same international economic event, Colombia and Côte d'Ivoire shared certain similar experiences but also faced different challenges. Let us review these one by one.

At the international level, the Colombian and Ivoirian states had the same expectations throughout the period under discussion. They were both important supporters of the coffee agreement prior to its collapse and worked tirelessly for several years to revive it through regular negotiations and discussions. Both countries clearly expected the ICA to be renewed at some point in one way or another. The domestic policies of both states following the disintegration of the agreement were in the end negatively affected by the failure to see their hopes realized. Both governments made policies with regards to the coffee sector assuming that the ICA would be renewed. It was several years in both countries before the governments and leaders accepted that there would be no further coffee agreements and that their policies needed to reflect this.

The two nations also had quite different relations with the international financial community at the end of the 1980's. Côte d'Ivoire was facing numerous economic problems due in part to the prior collapse in 1987 of another key commodity agreement for the nation, the International Cocoa Agreement. Côte d'Ivoire was thus already quite dependent on foreign aid, specifically assistance from the World Bank and the International Monetary Fund when the ICA fell apart. Côte d'Ivoire had already been subject to several unsuccessful Structural Adjustment Plans. The Colombian economy in general and its coffee sector were internationally in a stronger position. Colombia had 
thus not yet been subject to Structural Adjustment Plans and this would have an impact on how events would unravel differently in Colombia compared to Côte d'Ivoire.

In the countries under discussion, the importance of coffee in the national economy has changed over the years. Historically, in both places, the coffee business played an important role in national development by encouraging and strengthening the building of the state and the national physical infrastructure. However, it can be said that Colombia is now moving away from coffee production as its main source of income and export revenues. The government has made a conscious effort to move away from coffee and it can do so thanks to the development of other sectors, such as petroleum. The governments of Côte d'Ivoire would also like to move away from coffee and cocoa production, given the world markets; however, because of Ivoirian structural dependence on coffee, it needs to have a strong coffee economy before it can move on seriously to promote other sectors.

When comparing the two nations, it is important to consider the locus of decisionmaking in the coffee sector. In the case of Côte d'Ivoire, the national government led by President Houphouët-Boigny chose the policies which would affect the coffee sector. The Caisse de Stabilisation in many instances was an important part of the implementation of policy throughout the coffee sector; it was not, however, the decision-making center. The structure of decision-making in Colombia was quite different. As discussed in the previous Colombian chapters, FEDECAFE is an odd entity. It is a parastatal agency that actually transcends levels of analysis. It is an organization that is in fact part of the state at the one level, minimally involves the large producers at another level and exists in between 
the two somehow. Thus, when discussing policy determinations for the coffee sector, in Côte d'Ivoire, the discussion revolved and continues to revolve around the state. For Colombia, the decisions revolved mostly around FEDECAFE and still do, although to a lesser degree in the post-1989 era.

The Colombian and Ivoirian governments were at first equally unable to put forth coherent economic policies to deal with the crisis at hand. They both started out by exporting as much coffee as they could in an attempt to make up for the very low world coffee prices. Both governments moved away from this policy approximately two years later, realizing that this was no long-term solution to the crisis.

The Ivoirian state had to take drastic economic measures which would affect coffee growers much earlier than the Colombian state. The Ivoirian state cut the domestic producer price in half within a couple of months of the end of the ICA; it had not had and did not have the means to assist its producers with substantial financial and social programs during this crisis. In Colombia, the situation was different. FEDECAFE did have to reduce its social and financial assistance programs shortly after the collapse in international prices. The organization, however, was able, by choice, to maintain producer prices for two years and did not reduce the domestic price of coffee until late 1991. When it became clear at that time that the Colombian coffee sector was not doing well and that FEDECAFE no longer had the financial means to assist it in the fashion it had before, FEDECAFE called upon the state to step in and help coffee producers. The Colombian state proved at that point, by refusing to significantly assist coffee producers in their crisis, that it was no longer seriously interested in the coffee sector as a key economic sector of 
the economy. It viewed the sector as one that occupies geographic space on the Colombian territory and employs an important number of Colombian families, but not one that would move the country forward in its present and future economic development.

Despite differences in internal positions and policies, the two national governments were putting forth the same message to their coffee producers. The message to coffee growers was: the international markets are at fault for the terrible prices affecting our primary commodities, and coffee in particular. This message was more appropriate for the Colombian coffee sector and growers than it was for their Ivoirian counterparts. In the latter case, the structural dependence of the national economy on coffee had made the circumstances of the producers and the sector more difficult. The Ivoirian government would obviously not come forward and tell producers that the Caisse had been making money thanks to their hard work in coffee production and had spent all that money elsewhere. That would certainly have hurt the state's image at that point, considering its numerous credibility deficiencies.

The main focus of this dissertation has been on the parastatals involved in coffee in both countries. I have tried to answer several questions for each case. First, what were the actions and the policies of the parastatals following the disintegration of the ICA? Second, how were the parastatals themselves (FEDECAFE, Caisse, SATMACI) affected by the collapse in world coffee prices? How did the crisis change the parastatal's position in state-society relations? Finally, did the coffee parastatal contribute to national economic development? 
Studying the quite different financial situations of the two parastatals in their respective national economies at the time of the ICA breakdown also assists us in our analysis. The Caisse de Stabilisation in Côte d'Ivoire had been setting domestic producer prices in the country since its independence. It was profiting from each bag of coffee sold. The money from the profits was meant to be saved for more difficult times when world prices were low but this did not happen, even though this was the official argument behind the very creation of the Caisse and other African agricultural marketing boards. In addition, it did not, as in the case of FEDECAFE, reinvest the money into local coffeeproducing communities to promote the social and economic welfare of the coffee growers and their families.

When the international prices of coffee collapsed shortly after the prices of cocoa, the Caisse did not have any means to keep the prices at their previous levels. It also was not able to provide any social and financial assistance to the producers hardest hit by the sudden drop in international and domestic coffee prices. FEDECAFE was obviously in a better situation. Although it had over time reinvested much of the revenues obtained from coffee sales in the coffee-producing region by providing it roads, running water, electricity, and schools for example, it did have a number of financial assets as well as cash immediately available that it could use to keep the prices stable for an indeterminate period of time.

What actions did these two parastatals take to assist producers in 1989 and thereafter? In both case studies, the concern of the parastatals was for the quantity and quality of the coffee beans produced and exported. The original goal following the ICA 
disintegration, as discussed previously, was to export as much coffee as possible.

However, in the new economic situation, it was important that the quality of the coffee produced remain high in both countries despite the failure on the part of the growers to plant new trees, use fertilizers or invest labor costs to weed or trim coffee bushes. Côte d'Ivoire, in particular, needed to make sure that the coffee it exported was of good quality and did not include numerous other undesired particles. Some exporters had expressed concern about the quality of the coffee it produced. FEDECAFE also tried to maintain an emphasis on good quality coffee despite similar trends among the Colombian producers: decreasing use of fertilizers and unwillingness on the part of coffee producers to invest additional labor in their coffee fields.

During this time of increased exports in both countries, neither parastatal was able to provide much financial assistance to its producers. The Caisse just did not have the means to do anything for its producers. The SATMACI was involved in a program trying to assist those farmers who had just trimmed their coffee trees to renew their plantations. FEDECAFE was not able to provide direct financial assistance to the Colombian coffee producers because it was putting its emphasis on maintaining a stable price for them.

Two years after the ICA collapsed, both parastatals and governments realized that increased production and exports were not the answer to better international coffee prices. In both countries, the parastatals then emphasized the reduction of production but aspired for the maintenance and improvement of quality. This was the new way to obtain better prices in the international markets. In an attempt to alleviate the burden of the growers, FEDECAFE took a number of different and radical types of actions, such as reduction of 
coffee production, the eradication of trees, the diversification of crops in the regions, etc. It was able to do this in part because in addition to the low world prices, the Colombian coffee industry was fighting the broca. This allowed the sector to get more funds than it otherwise might have had to deal with the general coffee crisis at hand. The Caisse also encouraged farmers to produce other crops and continued to push for quality in coffee production.

For different reasons, both primary parastatal agencies and their representatives were concerned about their own existence and future. FEDECAFE leaders were worried about their organization because of the diminishing role of coffee in the national economy and its inability to represent the peasants freely and adequately. FEDECAFE's contract with the state to manage the finances of the coffee sector and organize the production and marketing of coffee is to be renewed every ten years. There was concern for FEDECAFE leaders and employees that in fact the state would decide not to renew the contract when it was up in 1997. In Côte d'Ivoire, the Caisse and the state leaders also had good reasons to worry about its future. The international financial institutions began demanding that the Caisse be transformed and privatized.

In fact, the parastatal agencies dealing with coffee were transformed during the years under study. The Caisse and its responsibilities in the Ivoirian coffee sector were radically diminished. In 1991, its guaranteed prices were eliminated, making way for nonbinding references prices that could be used by the industry. The control that the agency exercised over quality and transport of the beans was removed as well. The primary goal of these various state actions was to bring the production and marketing of coffee more in 
tune with the reality of international markets. The World Bank and the IMF urged the Ivoirian state in this direction. The SATMACI was eliminated as an independent agency and was merged with the other technical and extension state entities to form ANADER. This implied that the coffee producers would get even less specific technical assistance. The Federacion Nacional de Cafeteros was also altered during this time but in a different fashion. Instead of seeing its responsibilities diminish or being privatized by the state, the entity went through an important identity crisis. It could no longer provide the numerous social and financial services that it had been providing to the coffee region and the growers. It wanted to reformulate itself, not as the provider of state-like services but as the representative of all Colombian coffee producers. It was particularly interested in working on behalf of small and medium producers since it had not connected with them historically. This was its mission in the new world order.

The very different nature and origins of FEDECAFE and the Caisse go a long way in explaining the differences in the two coffee sectors. In the case of Colombia, the impetus for the organization originated equally with the state and a few, large coffee producers. In the case of Côte d'Ivoire, however, the impetus for the parastatal entity came exclusively from the state. There was no societal involvement in the creation of the Caisse at all.

The strength of the state in each country is another factor which helps to explain the differences between the two countries. The state in Côte d'Ivoire is a strong centralized entity which was led by the same president for more than thirty years. Ivoirian society however is generally seen as weak and unorganized, especially in its interactions 
with the state. Colombia, on the contrary, has always had a weak state, which does not penetrate all parts of its territory, and a strong, active civil society. This thus leads to different dynamics between the state and society in the two distant coffee sectors.

FEDECAFE no longer had the means to provide statal services for the coffee producers. It thus tried to move its focus to the representation of peasants more directly even though the ties to the state kept it from pursuing this avenue whole heartedly. It thus was stuck in between the state and the group it was supposed to represent, coffee producers. The parastatal had to defend itself vis-a-vis the state as well and this complicated matters. The Caisse continued to have a role in coffee production even though the price it set was no longer mandatory but rather a reference. Its role diminished little by little until it was eliminated in 1999.

What was the reach of the parastatal toward the peasants? Were its leaders and representatives able to disseminate their message, get the producers to respond to their policy choices and get them to understand the international context, for instance? FEDECAFE was better able to do this than the Caisse or the SATMACI. Although the Colombian state was not present in the countryside, FEDECAFE had done a fairly decent job of communicating with the producers. It was far from an ideal situation but they could get their ideas and policies across. In the case of Côte d'Ivoire, where the state was supposed to be stronger, it was even harder. With the Caisse, the SATMACI and a few disconnected cooperatives, the Ivoirian state did not really have a connection to the majority of the producers. The state portrayed itself as the friend of the growers, inviting a small number of them to roundtables and rallies for example. The average grower, 
however, did not get much information unless he specifically went looking for it. The Caisse was the state in the rural areas and it had more impact than any other entity in the area. This does not mean much, however, as it really was not particularly able to reach out to the peasants. With the diminishing role of the Caisse and the closing of the Caisse's rural transportation and quality control structures, it disappeared from the sight of producers. This changed the dynamic between state and society as it eliminated one of the few practical links that actually did exist between them.

All of this caused new problems for the coffee producers, big and small. For the first time in almost thirty years, they were now subject to the whims of private exporters and did not know how to interact or negotiate with them. Some would argue that the free market for coffee and the much diminished role of the state should actually bring about higher prices for the actual producers as a percentage of their earnings was not kept by the state. The reality, however, is that the international prices of coffee were so low following 1989 that the producers did not see their incomes increase at all. On the contrary, their incomes decreased.

At the level of the small producers, the impact of the new fluctuations in coffee markets was much the same in the two countries in question. In both countries, the producers faced significant reductions in their incomes and spoke out for the first time in the history of the two countries. This occurred at separate times in the two countries for reasons having to do with some of the differences existing between them. Ivoirian coffee producers noticed the effect of the change in world prices within two months of the ICA 
collapse, while Colombian growers only began to feel the difference in the markets after two years.

Farmers in both countries were obviously unhappy with their financial situation. In addition, however, they also became irate about their government's reaction to their plight or the lack thereof. They disagreed with state policies and parastatal response to their predicament. Their disdain for government policies went beyond just talk when producers in both countries took to the streets in protest. In Côte d'Ivoire, coffee producers were just one group among many marching against government policies in Abidjan in the spring of 1990 . The producers were in the streets comparatively rapidly following the beginning of the crisis. In Colombia, the coffee growers believed for a time that the Federation of Coffee Growers was there to protect them. It is when they realized that in fact, FEDECAFE could not help them and was not adequately representing them that they took to the streets in 1995 . Unlike Ivoirian farmers who marched in their nation's capital, the Colombian coffee growers marched in the coffee region's main cities and went on strike. In both countries, the marches and protests resulted in the creation of new groups to represent the coffee producers. In Côte d'Ivoire, the government allowed for the existence of new political parties and groups. At least one new producer association was formed to represent the producers, their needs and demands. These new associations have allowed for producers to speak out and for new voices to be heard in the countryside. In Colombia, many small producer groups came into existence to represent producers and their demands. It became obvious at some point that there were too many small groups arguing for the same goals. They then formed a Union of groups to represent all of them. 
They differentiated themselves from FEDECAFE, claiming that FEDECAFE was too close to the state to be able to represent them adequately. In both nations, these new associations did provide the farmers with opportunities to express their concerns; they did not and have not yet, however, brought about changes and solutions to the growers' problems.

It is interesting that Colombia is kind of an example for various parts of the Ivoirian coffee sector and other coffee-producing countries. While in Abidjan, numerous officials and individuals mentioned to me that what Côte d'Ivoire needed was a Federation just like the one they have in Colombia. I do not believe they understand totally either how FEDECAFE works today or how it worked. If they did, I don't believe they would be clamoring for it as much. FEDECAFE did not do a bad job for the coffee sector as a whole but it did not do particularly well in its attempt to organize all producers and represent them. They went down into the streets the same way the Ivoirian ones did, demanding many of the same things.

We have thus seen that despite the different state structures and economic situations facing the two countries under study in this dissertation, a number of similar trends surfaced in both countries. In both instances, the coffee producers got more politically involved by descending into the streets. This had never been seen in either country before. It is fair to say that the societies studied in this dissertation became more engaged and more interested in the policies and decisions chosen by the state. This is one of the few positive outcomes of the collapse of the ICA. 
In both case studies, the parastatals discussed have been transformed and their role in the coffee sector has been seriously limited. Through these entities and their decreasing role in the coffee business, the state also became less interested and less involved in coffee. Up until now, it has not particularly responded to the more explicitly voiced concerns of the producers. The states seem to be disengaging themselves from the coffee business, even though in the case of Côte d'Ivoire, the economy still depends very much on coffee as an export crop.

In the end, did the coffee parastatals under study contribute to the national economic development of the two countries? It is clear historically that the coffee sector as a whole played a large role in national economic development in Colombia and in Côte d'Ivoire. For the parastatals themselves, the results are mixed. It is undeniable that FEDECAFE stepped in and assisted in the development of numerous rural coffeeproducing regions throughout Colombia. FEDECAFE did take its role as the organizer and administrator of the coffee sector seriously and overall was able to make coffee a productive sector for the Colombian economy, allowing it to expand and move into other sectors. In addition, without the Federations' s participation and statal role, some of these rural coffee-producing areas would still today be without electricity and running water. I would thus argue that FEDECAFE as a parastatal organization had an important role in the economic development of Colombia.

Can the same be said of the Caisse de Stabilisation des Cours? In Chapter V, I quoted Houphouet-Boigny as thanking the Caisse for its contributions to Ivoirian economic development. The coffee and cocoa sectors together were in large part 
responsible for the almost twenty years of the Ivoirian economic boom. The Caisse definitely provided necessary foreign exchange to the Ivoirian economy. It also aided financially loyal followers of the President and individuals working on projects considered important for Cote D'Ivoire's overall economic development (such as the large sugar complexes in progress in the Northern part of the country). Unfortunately, the Caisse and the other statal entities working in the coffee sector did not provide the majority of small coffee growers with much technical and financial assistance. The Caisse also did not reinvest socially in the coffee region the way FEDECAFE did. In the case of Côte d'Ivoire, I would thus argue that the coffee sector as a whole played an important role in national economic development, not the Caisse itself. The financial options pursued by the Caisse did not benefit either the coffee producers themselves or the national economy as a whole. In fact, the lack of funds in the Caisse's accounts in the early 1980's worsened the economic situation of the country and only delayed further the nation's economic development.

The comparison of these two parastatals does not provide us with definitive conclusions with regard to the role of parastatal agencies in general in development. FEDECAFE and the Caisse provide us two very different scenarios of how parastatals participate in economic development. In the first instance, FEDECAFE clearly provided impetus for serious and rapid economic development. In the second instance, the Caisse participated in development in much more convoluted ways and cannot be seen as a clear positive engine for development. I thus believe that these entities can be helpful in economic development but can also be more harmful. 


\section{Bringing In Other Coffee-Producing Countries}

Adding other coffee-producing countries to this analysis will allow us to draw more specific conclusions about the fate of these countries in general following the disintegration of the ICA. When reviewing developments in a variety of these producer countries, it becomes clear that they all have had similar experiences, regardless of the structure of their coffee sector and their official position vis-a-vis the International Coffee Agreement.

The countries included here were all very dependent on coffee production in 1989 and were all members of the International Coffee Organization. I added Brazil, Costa Rica, Indonesia and Uganda to this comparison for several reasons. Brazil is still today the largest coffee-producing nation in the world and it is thus necessary to include it in this comparison. Costa Rica has been very dependent on coffee exports throughout its history and is one of the few countries producing coffee that is very similar in quality to Colombia's Arabica coffee. Coffee has been for several decades Uganda's primary and essential export crop, despite serious political crises. Including Uganda also enables us to get the perspective of another African country which depends significantly on coffee exports. Indonesia represents the few Asian countries which began producing coffee in large quantities in the second half of the twentieth century; it has now also joined the ranks of the most important coffee-producing countries in terms of its output.

What was the official position of these various states vis-a-vis the International Coffee Agreement and its renewal? Of the countries added in this comparative chapter, Brazil and Uganda were in basic agreement with the International Coffee Organization. 
Brazilian government leaders were in favor of the status quo in 1989. They were prepared to sign a new ICA with the same parameters as the previous one. They were completely unwilling to give up any part of the large Brazilian ICO export quota (30 per cent) or even to discuss that possibility. ${ }^{1}$ Similarly, Ugandan state officials were seriously pushing for a renewal of the agreement and were also not seeking any changes as far as Uganda's position or quota in the world coffee economy.

Costa Rica and Indonesia were both officially in favor of the agreement's collapse because their leaders wanted their nations to get larger coffee export quotas in the international market. Costa Rican leaders believed that a temporary free market would allow them to gain a better market position for Arabica coffee, in direct competition with the larger Colombian coffee production. The Indonesian government was in fact quite pleased with the collapse of the coffee agreement as it was totally unsatisfied with the official quota it was given year after year. It wanted to be ranked officially as the world's third largest coffee producer. It regularly exported large quantities of coffee to the countries not member of the ICO (Annex B countries for example) in order to increase its coffee exports and sales.

A review of the events in the coffee sectors of these four countries indicates that regardless of the starting positions of the various governments, they all ended up in similar official stances. A few years after the disappearance of the agreement, the leaders of these countries were all in favor of an agreement renewal, even under the former guidelines.

${ }^{1}$ Economist Intelligence Unit, EIU Country Report Brazil, 1, 1990 (London, United Kingdom, 1990), p. 15. 
This is because the end of the agreement had comparatively negative consequences for their respective coffee sectors.

The impact of the low coffee prices on the individual countries is described in much the same way. Here is a brief sampling of the statements written about the situation in each country in the individual country reports of the Economist Intelligence Unit: "The breakdown of the ICA in July 1989 ...appears to have harmed Brazil more than other countries (in particular Colombia) which have managed to increase the volume of their exports and thereby compensate for lower world prices;"2 "the effective collapse of the ICO quota system in July 1989 has been extremely serious for Uganda because robusta prices have fallen without a safety net;" "the fall in international coffee prices has led many coffee growers in Costa Rica to bankruptcy,"4 and "the Indonesian coffee industry has been severely hit by the low prices prevailing in world markets since the suspension of the quota system operated by the ICO."

All the countries and their coffee growers suffered from lower prices for their coffee crops. Although many of them thought that they would be able to export more coffee and did not overly concern themselves with the prices; in fact, they were very much

${ }^{2}$ Economist Intelligence Unit, EIU Country Profile Brazil, 1991-92 (London, United Kingdom, 1992), p. 22.

${ }^{3}$ Economist Intelligence Unit, EIU Country Profile Uganda, 1993/1994 (London, United Kingdom, 1994), p. 16.

${ }^{4}$ Economist Intelligence Unit, EIU Country Report Nicaragua Costa Rica Panama, 4, 1992 (London, United Kingdom, 1992), p. 24.

${ }^{5}$ Economist Intelligence Unit, EIU Country Report Indonesia, 1, 1992 (London, United Kingdom, 1992), p. 33. 
affected by the extremely low prices. Across the world, coffee producers felt the price differential and thus decreases in income at different times; they would be in particular need for financial, economic and social assistance on the part of their national governments.

Part of the problem for the coffee growers in these various countries is that the state institutions themselves were feeling the impact of the changes in the world coffee economy in several ways. On the short term, the profit margins of the coffee institutions decreased and were eliminated. On the longer term, the state structures to deal with coffee would be transformed in all cases.

The state institutions existing in the coffee sectors of the four countries under study were quite similar from the start. The Instituto Brasileiro do Café (Brazilian Coffee Institute, IBC), the Instituto Costa Ricense del Café ( Costa Rican Coffee Institute, ICAFE), the Coffee Marketing Board (CMB) in Uganda, and the Association of Indonesian Coffee Exporters (AEKI) in Indonesia were all parastatal entities which regulated and controlled the production and export of coffee in the different countries. Within a few years of the end of the ICA, these entities were totally privatized and thus opened up their coffee sectors to the ups and downs of the international markets.

What was the position of these parastatal agencies with regard to state-society relations and national development? The IBC in Brazil was very much part of the national state bureaucracy; it formulated and implemented Brazilian coffee policy. ${ }^{6}$ Because of the

${ }^{6}$ Robert H. Bates, Open-Economy Politics: The Political Economy of the World Coffee Trade (Princeton, NJ: Princeton University Press, 1997), p. 95. 
size of the Brazilian coffee production, the IBC also had a significant economic position at the international level. Following the collapse of the coffee agreement, in early 1990, the IBC was eliminated. ${ }^{7}$ Another agency, FUNCAFE, was set up to handle the assets and debts of the IBC. Brazil is peculiar among the countries discussed because, despite its impressive market share, coffee does not represent a significant source of export revenues (less than five per cent) for the Brazilian economy. Coffee producers were not be pleased with the dismantling of the coffee parastatal, but they were ultimately unable to stop government policy. ${ }^{8}$ Responsibilities for the coffee sector are now divided between the Minister of Economy and the Ministry of Agriculture. The collapse of the coffee agreement thus resulted in the elimination of the Brazilian coffee parastatal. Because coffee represented such a small portion of the national economy, the disintegration of the agreement and the disappearance of the IBC did not have a significant impact on national economic development.

The Instituto Nacional del Café (National Coffee Institute, ICAFE, formerly the Institute for the Defense of Coffee and the Office of Coffee) in Costa Rica seems to have origins similar to those of FEDECAFE in Colombia; it came about first as a result of work by the coffee elites. It was nationalized in 1948 and, according to a leading processor quoted by Paige, "regulates completely all the relations between the small farmers, the millers, the exporters, the domestic industry. It is an excellent system and a model for

${ }^{7}$ Economist Intelligence Unit, EIU Country Profile Brazil, 1990-1991 (London, United Kingdom, 1991), p. 21.

${ }^{8}$ Economist Intelligence Unit, EIU Country Report Brazil, 2, 1990 (London, United Kingdom, 1990), p. 9. 
others to imitate...."9 This institute is a government agency but has close ties and involvement with the coffee elites and the private sector.

Following the disintegration of the coffee agreement, the Institute sought real solutions to the farmers' problems. It modified the coffee export tax structure in place to fluctuate with the world coffee prices so as to give the producers some economic leeway when the prices were extremely low. ${ }^{10}$ The World Bank had in fact singled out Costa Rica as one of few countries that would do better without the coffee export quotas. ${ }^{11}$ The coffee farmers in this small Central American country faced particularly difficult times through the mid-1990's. According to Sick, they "adjust[ed] their production strategies, often choosing to cut back on applications of expensive fertilizers, herbicides, and pesticides." 12 They also sought ways of increasing their income by either producing other crops on the side or working for wages. Sick believes that the majority did not seriously consider abandoning coffee production entirely. As the Costa Rican producers and coffee sector continued to face hard times, ICAFE was returned to the private sector in an attempt to restructure the state and make its bureaucracy leaner. ${ }^{13}$ In this case, the

${ }^{9}$ Jeffery M. Paige, Coffee and Power: Revolution and The Rise of Democracy in Central America (Cambridge, MA: Harvard University Press, 1997), pp. 233-234.

${ }^{10}$ Economist Intelligence Unit, EIU Country Report Nicaragua, Costa Rica, Panama, 4, 1990 (London, United Kingdom, 1990), p. 23.

${ }^{11}$ Economist Intelligence Unit, EIU Country Report Nicaragua Costa Rica Panama, 3, 1989 (London, United Kingdom, 1989), p. 18.

${ }^{12}$ Deborah Sick, "Coping With Crisis: Costa Rican Households and The International Coffee Market," Ethnology, 36, 3 (Summer 1997), pp. 255-75, p. 260.

${ }^{13}$ Economist Intelligence Unit, EIU Country Report Panama Costa Rica, 3, 1995 (London, United Kingdom, 1995), p. 20. 
parastatal was contributing to economic development. The disintegration of the ICA and the privatization of ICAFE negatively affected the overall Costa Rican economy.

Prior to 1990, Uganda's coffee industry, representing over 90 per cent of country's export revenue in that year, was under very tight government control. The Coffee Marketing Board (CMB) had a monopoly over the regulation and the trading of coffee and was created exclusively by the state with the Coffee Marketing Act of 1969. The Ugandan producer price of coffee in 1990 , following the collapse of the ICA, was ten per cent of the world price for Robusta. In 1991, the government allowed competition in coffee trading; four cooperative unions thus entered the coffee sector. The Ugandan Coffee Development Authority (UCDA) was created as a private entity to oversee the regulation of the sector and promote its development. The Coffee Marketing Board was now only one of several entities trading in coffee. It temporarily remained a state agency, until an appropriate private buyer could be found. By 1996, it handled less than 10 per cent of the coffee exports. ${ }^{14}$ According to Bigsten and Kayizzi, "the CMB had all the shortcomings of the parastatal sector but none of the potential strengths given by its autonomous and strategic position in the coffee marketing. CMB's traditional dependence on a hierarchy of institutions, from the cooperative union down to the primary society, had long ceased to be an asset; insensitivity to farmers' needs at the union level and below had turned this infrastructure into a liability." 15

${ }^{14}$ Anne Bigsten and Steve Kayizzi-Mugerwa, Crisis, Adjustment and Growth in Uganda: A Study of Adaptation in an African Economy (New York, NY: St. Martin's Press, 1999), p. 77.

${ }^{15}$ Bigsten and Kayizzi-Mugerwa, p. 75-76. 
These changes in the government's handling of the coffee sector and the real crisis faced by producers radically modified the coffee sector in Uganda, according to analysis posted on the International Coffee Organization's website. ${ }^{16}$ Ten per cent of Uganda's coffee-producing area had been abandoned by $1994 .{ }^{17}$ Many producers who did not leave that part of the country began producing other crops. However, the sector as a whole was much more productive and was producing better quality beans. Coffee provided Uganda with national revenue during times of political crises and continues to participate in national economic development. The liberalization of the coffee parastatal agency seems to have been positive for the Ugandan economy.

The Indonesian Coffee Exporters Association (AEKI) is a government-backed organization, claiming to represent the interests of the Indonesian coffee producers. It does not appear to be part of the government bureaucracy but works very closely with the government on coffee policy. It regulates the industry, licenses coffee exporters and provides extension and technical services alongside the national government. Following the collapse of the ICA, the licensing rules were changed so that any export business in Indonesia could export coffee. The AEKI leaders fought this significant change in regulation as it would mean more economic losses for their organization. ${ }^{18}$

${ }^{16}$ www.ico.org/pub/puprof2.html, May 19, 2000.

${ }^{17}$ Economist Intelligence Unit, EIU Country Report Uganda, 4, 1994 (London, United Kingdom, 1994), p. 17.

${ }^{18}$ Economist Intelligence Unit, EIU Country Report Indonesia, 3, 1990 (London, United Kingdom, 1990), p. 19. 
The leaders of the Indonesian coffee industry favored the dissolution of the ICA as they believed it would bring about a significant increase in their exports. During the negotiation meetings held after the disintegration of the coffee agreement, Indonesia did not modify its bargaining position, even though over the course of the subsequent years, it was seriously affected economically. The disintegration of the ICA, however, did not result in increased Indonesian coffee exports, in large part because of serious international concerns regarding the quality of Indonesian coffee. "A common complaint by consuming countries is that Indonesian coffee arrives in unusable condition, having fermented and become moldy in transport."19 This was one of the main issues that needed to be addressed by the coffee organization and the government in the post-ICA years. The collapse of the coffee agreement thus had a negative impact on the Indonesian coffee sector and economy. Its parastatal was not transformed as a result of the crisis, probably in part because of the serious quality issue.

All of the countries discussed, except for Brazil, needed significant foreign assistance (table will be provided with figures on multilateral and bilateral aid to the coffee-producing countries mentioned in this chapter) in order to recover economically from the collapse of the international coffee markets and other problems they were facing. Thus, they were all subject to Structural Adjustment Plans put together by the World Bank and the International Monetary Fund. In general, they were pushed to diminish state involvement in the country's economy and eliminate or decrease the input of the state institutions in the coffee production and marketing process.

${ }^{19}$ Far Eastern Economic Review, August 10, 1989, p. 44-45, p. 45. 


\section{Grinding It All Together}

A number of the issues discussed in the previous section are similar to the situations and problems encountered in Colombia and Côte d'Ivoire. It is fair to say that overall, the coffee industry worldwide was transformed by the collapse of the International Coffee Agreement.

In the majority of the coffee-producing countries, the coffee sector was significantly liberalized. The extent to which the industry was transformed in each instance depended in part on the position of the state and parastatal agencies in the sector, its role in the overall economy and the economic situations of the countries at the time of the ICA collapse. The overall role of statal agencies in the coffee business was diminished, for better or for worse. In many countries, such as the Ivory Coast and Brazil, change came just a few months after the disintegration of the coffee agreement. In other nations, such as Colombia and Costa Rica, the transformation of the coffee business was much slower.

Intuitively, some would argue or hope that the disappearance or elimination of these statal entities and marketing boards would almost automatically increase the revenues of the majority of small producers in the countries under study, as the percentage of income intercepted by the state agencies decreased. This is generally, however, not the case as the international prices of coffee were so low following the disintegration of the agreement that the actual producer prices of coffee went down as well. It is not possible to indicate what would happen in the case of a sustained price increase as there has not 
been one since 1989. Is the elimination of the parastatals a sign that the market is functioning well?

The producers of coffee throughout the world felt the impact of the breakdown of the coffee agreement in the lower producer prices they received for their crops, regardless of their national origin. How quickly producers saw their incomes drop depended in large part on the structures of the national coffee sector and the financial situation of the statal agencies involved. In most cases, the producer price of coffee decreased quickly in late 1989. Colombia, as we saw, was an exception in this regard.

Even though some coffee-producing countries such as Costa Rica and Indonesia were pleased with the collapse of the ICA in 1989, it is clear that even they were not prepared for the rupture of the agreement to be anything more than temporary. The goal was always to gain a better position for their countries in preparation for the inevitable renewal of the agreement. Not one of these nations was prepared for the possibility that there might not be another International Coffee Agreement at all. As seen with Colombia and Côte d'Ivoire, this early blind belief in the eventual renewal of the agreement brought with it a set of national economic policies that did not particularly aid the producer countries on the long-term.

Parastatal organizations throughout the coffee-producing Third World were radically transformed throughout the period under study. In a majority of countries, these entities were entirely privatized or eliminated. In the few other nations, the parastatal was trimmed down significantly in its regulatory, financial and technical responsibilities. In my opinion, the origins of the parastatal elucidate significantly its mutations. Those entities 
that were created, at least in part, by societal interest in the coffee industry, were more likely to remain in existence as their role in the coffee economy was at least superficially different from the role played by agencies that were exclusively created by the state as an extension of it. For example, the Colombian and Indonesian organizations both continue to operate and work to influence developments in coffee production in their respective countries. In Côte d'Ivoire and Uganda, however, the state agencies were eliminated.

Overall, Colombia does stand out for a variety of reasons. The country's economic position was strong even for the first few years after the collapse of the coffee agreement. This meant that unlike other countries, it did not have to be scrutinized at first by the international financial institutions which studied the other countries. In addition, once the international financial institutions did get involved in the Colombian situation, the odd nature of the National Federation of Coffee Growers as a parastatal but not exclusively a state entity made it a difficult target for foreign economists. Although it acted as a state agency and performed many of the same functions that the marketing boards and other parastatal entities did in the other countries mentioned, it did not get the same scrutiny and was not on the target list of international financial institutions.

What does all of this say about the parastatal institutions under study in coffee sectors throughout the Third World? Do they help or hinder national economic development? They were and, in some countries still are, important agencies in the Southern countries for a number of reasons. These organizations played an important role in their nation's political economy regardless of their statal or societal origins. They came into being when the ideological consensus in the development community was that the 
state should be the primary motor of development. They were to regulate and organize the key economic sectors of the nation; they were to help shape the country's economic future. This was done by imposing taxes on producers and/ or exporters and managing (short of investing) the proceeds.

Did they fulfill their economic mission? It is difficult to quantify the impact that the parastatals have had on a sector of the economy or the entire national economy. I would argue that parastatals could have a very beneficial impact on national development. In the two case studies of this dissertation, the results are mixed. I would argue that despite its difficulties, FEDECAFE did provide Colombia with the means to forward the national economy and it did provide economic and social assistance to the coffee sector itself. Even after the collapse of the world prices, it was able to maintain the Colombian producer prices at levels that made coffee growers in other countries jealous. In Côte d'Ivoire, the goals of the Caisse were hopeful. It is in the implementation of those aims that the Caisse did not fulfill its mission. In part, some of its economic means were squandered among loyal followers of Houphouet-Boigny. In addition, however, the remaining funds were invested in large projects that did not prove to be particularly sound economically. Thus, in times of crisis, there were no resources available to assist the peasants.

Despite the mixed economic results of these organizations, one of the important contributions of parastatals is in the realm of national state-society relations. In many instances, these entities became links between the state and society. In societies, such as the Ivoirian one, that were just crafting national identities and working to create a national 
society independently of ethnic and religious ties, the buildings belonging to the parastatal in the rural areas became loci for exchange of information, regarding government policy and technical assistance and producer perspectives. In the case of Colombia, the "statal" nature of FEDECAFE gave the state unequaled access to rural areas in which it was otherwise not present at all. Producers came to gather information and request assistance; the statal agency could also use the contact to spread the word regarding its policies and perspectives. The dialogue, although sometimes basic, was helpful in building a national society in many of these countries.

The presence and existence of these parastatals in the rural coffee-producing areas of the world's Southern countries thus had some unexpected benefits for the developing societies. It is unclear, in those countries that have eliminated the parastatal, what organization or organizations will fill that gap. 


\section{CONCLUSION}

"The commodity agreement movement is effectively dead, " according to Gilbert. ${ }^{1}$ It is clear that no new International Coffee Agreement will be signed in the foreseeable future. The prevailing ideology among World Bank and International Monetary Fund economists is that neoliberal reform is the most sensible plan for developing countries throughout the globe. The multilateral aid packages distributed to Third World countries are dependent upon their pursuing structural reforms liberalizing their economies and opening up their political systems. As discussed in more detail in Chapter I, the international economic landscape has changed considerably since the coffee agreement's collapse in 1989.

This dissertation has focused specifically on the domestic implications of this significant international event for the Colombian and Ivoirian coffee sectors. I studied in detail how these two nations reacted and adapted to the important change in their international environment. We learned that although the two countries under study are very different, the overall impact of the ICA's disintegration was quite similar in both places. We saw how the developing state is very directly affected by important price decreases of its most significant commodities and how its society responds to the change at the various levels of analysis.

${ }^{1}$ Christopher Gilbert, "International Commodity Agreements: An Obituary Notice," World Development, 24, 1(1996), pp. 1-19, p. 1. 
In particular, I analyzed the transformation of the parastatal organizations which were responsible for state coffee policies in both cases: the Federación Nacional de Cafeteros de Colombia in Colombia and the Caisse de Stabilisation et Soutien des Prix Agricoles in Côte D'Ivoire. I worked to understand their historical and current roles in state-society relations and in the national political economy. Because of the importance of coffee in the Colombian and Ivoirian economies, the two coffee parastatals accumulated significant power and funds. They were at the very center of these developing economies and societies and thus played an important role in the path of these countries.

Institutionally, these parastatal organizations were quite different. The Caisse was an official state agency and was a key component of the Ivoirian state bureaucracy. FEDECAFE, however, was not part of the Colombian state. FEDECAFE was created by large coffee producers but was very closely tied to the state through financial and structural agreements.

As discussed in previous chapters, the emphasis throughout this work has been on the functional similarities between the two coffee parastatals. It is after all these common duties that enabled me in large part to compare the two entities. Until the early 1990's, FEDECAFE and the Caisse shared a number of responsibilities with regard to the Colombian and Ivoirian coffee sectors, including setting the domestic producer prices, taxing the producers, marketing the coffee crops, monitoring crop quality and productivity, and serving as a link between the state and the coffee producers.

In addition, they were both in charge of allocating the coffee tax revenues but they did so in very different ways. FEDECAFE used the majority of the available funds to 
reinvest in the coffee sector itself by providing much needed social services to the producers, including roads, electricity, running water, education, technical assistance. The Caisse, on the other hand, used the income outside of the coffee sector, for the purpose of political patronage and support for large unrelated projects.

The functional similarities between the two parastatals decreased significantly following the collapse of the International Coffee Agreement, especially with regard to the assistance these entities could provide to the coffee producers. FEDECAFE had funds available to keep the Colombian producer prices high for approximately two years after the decline of world prices. However, it could no longer fulfill its responsibility as the main provider of social and technical services for the coffee producers. The Ivoirian Caisse, similarly, had to change some of its tasks. It was not in a financial position to assist the farmers after 1989. This was due to both its previous investment choices and the previous financial pressures on the state agency, including the collapse of the International Cocoa Agreement. Within a few years, the role of the Caisse within the Ivoirian coffee sector would also change and decrease drastically. It would no longer set coffee producer prices or control crop quality and productivity. In addition, the SATMACI, which carried out the technical assistance programs in the coffee sector, was not able to provide the producers with additional technical or social assistance during the crisis in the early 1990 's.

The substantial modification in the functions of the two parastatals in the new world coffee economy also led to transformations of the parastatal agencies themselves. They both faced issues of new missions and survival. FEDECAFE has had to rethink its 
entire raison d'etre. It has always been in an odd position between the Colombian state and the Colombian coffee growers, primarily because of its state-like and financial responsibilities. It was part-state and did not mind that position as long as it was providing important services to the coffee producers. However, when the international context changed and the state pulled back from its interest in the coffee region, the Federation was stuck between a state not committed to coffee production and producers rejecting its leadership and representation. FEDECAFE argued for the right to represent the producers, claiming that its close link to the state would enable it, as opposed to other producer associations, to gain concessions for the growers.

Although the Caisse de Stabilisation was obviously much more directly linked to the Ivoirian state and thus was not in the awkward position experienced by FEDECAFE leaders, it also changed drastically through this difficult period. At first, the duties of the CSSPPA within the national coffee economy were diminished. Specifically, its revenue extraction abilities were cut substantially, mostly because of the external influence of the International Monetary Fund and the World Bank. Ivoirian leaders did maintain this downsized parastatal in existence for a number of years, as they believed it had an important role to play in coffee exporting. It still determined producer reference prices and collected information regarding the coffee sector. Part of the issue for the Ivoirian leaders and Houphouet-Boigny in particular is that they viewed the Caisse as an important element in both the Ivoirian economic landscape and Ivoirian national identity. It was after all directly associated with Côte d'Ivoire's major economic boom. In the final analysis, however, the Caisse, as a state agency managing coffee production and its 
profits, was totally eliminated from the Ivoirian coffee lanscape. Again, the push for this final blow to the marketing board came from the international financial institutions.

I argue in this dissertation that the differing origins of the two parastatals under study provide part of the explanation with regard to the eventual outcome for the parastatal following the collapse of the ICA: survival or elimination. The impetus for the Federation in Colombia came from large producers. Even though the state had a key role in the existence of the Federation, large coffee growers were the impetus behind its creation and maintained a key role throughout its existence. They did not disappear after 1989 and were one of the reasons for the continued survival of the organization. The Colombian could not decide to do away with FEDECAFE. The Caisse, meanwhile, was first created by the French colonial authorities in an attempt to organize coffee production and profit from the colony. Large and small African coffee producers were certainly not involved in the creation of this colonial entity. Following Ivoirian independence, Houphouet-Boigny and his colleagues, who were mostly large coffee producers, maintained the agency in existence as it was providing the country with much needed revenue. It also enabled them to control coffee production. The involvement of these large producers in the Caisse and in the state, however, did not result in policies that were necessarily friendly to all other producers, specifically the small ones.

The two parastatals under study also faced historically very different states and political environments. Since its independence, Côte D'Ivoire has had a strong state which until 1994 was personalized by President Houphouet-Boigny. Ivoirian society as a whole has not collaborated in the creation of the national state and state policies. Colombian 
society faces a different type of state: a weak one which is not present in all parts of the country. It has not been able to provide services or maintain peace throughout its national territory

Another determining factor in the different results for the two parastatals under study is the international economic situation of the two countries and coffee sectors involved at the time of the disintegration of the International Coffee Agreement. Côte d'Ivoire, specifically, was in much weaker position than Colombia. The collapse of the International Cocoa Agreement in 1987 among other things cut Ivoirian revenues, forced the state to cut back on investments and stretched it financially. The Ivoirian state in this precarious state of economic affairs did not have many options in terms of outside assistance; it almost immediately had to begin negotiating with the International Monetary Fund and the World Bank This implied that the Ivoirian government had to agree to some of the structural adjustments discussed at the beginning of this conclusion. The elimination of the Caisse was carried out in large part because aid from the financial institutions in Washington was dependent on it.

Colombia was more independent in its handling of its coffee crisis and the future of the parastatal as it was not dependent on immediate multilateral foreign assistance. The World Bank and the IMF did not play a role in the resolution of the domestic Colombian coffee crisis. The coffee sector as a whole in Colombia was in a better financial position than the Ivoirian one, as indicated its ability to maintain producer prices for almost two years. 
The breakdown of the ICA and state inaction on the medium term resulted in similar reactions by the producers of Colombia and Côte d'Ivoire. The growers in both countries realized that the state was not interested and/or able to assist them in these difficult times. FEDECAFE could no longer provide Colombian growers with the social services to which they were accustomed and the Caisse was not able to maintain producer prices of coffee.

In the case of FEDERACAFE, the producers believed that it could not effectively lobby for their needs. They did not, however, demand its elimination. They simply wanted to create other parallel producer associations to more accurately represent their interests. For the first time in Colombian history, Colombian coffee producers marched in the streets and created other producer organizations to represent them.

The Ivoirian producers, who had never really had advocates to speak out on their behalf, began creating associations and making their demands known. They also protested in the streets of Abidjan for the first time in their country's brief history, forcing their President to allow them to organize.

In both nations, the participation of the smaller producers in the political scene was thus a first. Both countries had seen larger producers involved in the creation of FEDECAFE and the Caisse but had never seen much involvement on the part of the small growers.

The collapse of the International Coffee Agreement thus brought about new dynamics in state-society relations in the two countries under study. In both instances, we have a state pulling back or disengaging while the society is organizing and engaging the 
state with the creation of associations to represent its needs. These changes could be positive in the long-term as they imply more involvement on the part of civil society in Côte D'Ivoire, which until now has had a weak civil society. The creation of other producer organizations in Colombia continues to create a strong civil society there.

Beyond the functions of these parastatals and the various factors that influenced their outcomes, let us explore their overall impact on the two coffee sectors and national economies.

First, FEDECAFE and the Caisse both participated in solidifying the importance of coffee for national economic development in Colombia and Côte D'Ivoire. As mentioned in other chapters, the revenues from coffee production and marketing allowed both parastatals to assist the state in its actions and financial security, both within the coffee sector and outside of it. FEDECAFE provided an impressive level of social services to the coffee producers who until then had received no assistance. The Caisse through its profits provided income for political patronage and large development projects. The funds accumulated through these taxes enabled these two entities to participate in national development, well beyond the confines of the coffee sectors they sought to control. They did make some loans to coffee producers enlarging their farms or increasing their productivity but provided much capital for projects throughout the two countries. Without the parastatals and their tax collections, this money would simply not have been available to the two states in any form.

In addition, although the producer prices were rather low, the growers appreciated the guarantee that they would always be able to sell their crop, even at a low price. This 
encouraged them to produce more coffee. This would obviously then increase their income as well as the revenues of the parastatals.

In addition, FEDECAFE and its technical Ivoirian counterpart, the SATMACI, provided technical assistance to the growers by providing them with scientific research on coffee trees, free coffee plants, and technical advice in various forms. These activities as such do not seem particularly important but it is in fact through agricultural extension and the outreach to involve growers with technical and educational programs that the parastatals really distinguished themselves.

In Colombia and Côte d'Ivoire, the quasi-state agencies filled a large void in the relations between the state and coffee producers. In Colombia, FEDECAFE served as a representative of the state in areas where the state was not present; it served as a conduit for state information which would otherwise have been unavailable to coffee growers. In Côte d'Ivoire, the Caisse also assisted the newly independent Ivoirian state in reaching out to producers as it was the only state office in many towns. I argue throughout the dissertation that this is one of the parastatals' most important functions, even if it often goes unnoticed. I do believe that their contribution to the state-society relations has been understudied.

In addition, at the international level, the two state agencies also played an important role vis-a-vis the International Coffee Organization. They were responsible for the collection of coffee data on key issues such as production, exports, producers, use of fertilizers, etc. The parastatal also is in part responsible for the country's implementation of the coffee agreements. It controled national exports and their quality. 
In a number of countries other than Colombia and Côte D'Ivoire, the creation of a parastatal entity was in practice directly related to the signing of the International Coffee Agreement. This is particularly the case in some of the Central American and Asian countries which significantly increased their coffee production during the four ICAs.

The parastatals studied in this dissertation thus shaped and influenced significantly the coffee sectors and national economies within which they operated. Are these parastatals then good for national economic development? Would these two countries have been worse off without the interventions of the parastatals in their economies? Absolutely. The overall impact of the parastatals in the two countries, in my opinion, is positive. I do acknowledge, however, that not all of their functions were so positive for the producers and/or the economy. Their management of the coffee sectors was and has been far from perfect.

Let us remember that, at the time of their creation, parastatal organizations of this kind were given key responsibilities in Southern countries because development theorists and practitioners across the world believed in the overwhelming importance of the state and its agencies in development. They could not imagine another entity fulfilling the tasks of the state in development.

Can I speculate what would have happened in both countries without the existence of these parastatal agencies? The coffee sectors in both countries would have been structured quite differently, as the parastatals would not have served as the centers of financial, technical and export activities. The Ivoirian and Colombian states would not have benefited from the centralized source of funds available in the two parastatals. States 
would have had no way to reach out to the small growers. Producers would have exported coffee independently, through a variety of routes at varied prices. Beyond the structural aspects of this scenario, the producers would not have continuously increased their coffee production. The surrounding industries would not have seen the economic benefits of a booming coffee sector. The systematic revenue extraction may not have existed in the same fashion, but there may have been other related mechanisms in place. One needs to only look at a few African countries where the state has collapsed to envision other types of rent-seeking arrangements.

Overall, then, I do believe that these parastatals fulfilled a number of important functions within their coffee sectors. They contributed to the national economic development of the two countries under study, even if not all aspects of their mission were positive.

My argument throughout this dissertation has been that the collapse of the International Coffee Agreement brought about important changes in the functions of FEDECAFE and the Caisse and in the process transformed state-society relations in the two coffee sectors.

It is hard to imagine what the world coffee markets would have done without the International Coffee Agreements from 1962 to 1989. It is telling that all the countries brought into the discussion in the comparative chapter, regardless of their positions when the agreement disintegrated, came around to believe that the ICA had a positive effect on their economies and were all pushing for its return. Even those countries that thought they would be better off without the ICA wanted the agreement to be reinstated. I believe 
that this says something about the agreement itself and the perspectives of the countries involved.

I would argue that the collapse of the International Coffee Agreement had a greater impact on the coffee-producing countries than anyone anticipated or at this stage is willing to acknowledge. A number of the important coffee producers are currently facing particularly difficult economic and political situations. Obviously, Colombia is the prime example, fighting the cultivation and sale of drugs and the presence of powerful guerrilla movements in several parts of its national territory. Côte d'Ivoire is not in the news as much, but is currently going through the most severe political crisis of its independent era, having now experienced two military coups in less than one year. In a different part of the world, Indonesia has been rocked by serious political instability. I am not arguing that these situations are direct results of the collapse of the International Coffee Agreement. I am asserting, however, that the significant economic and political problems linked to the disintegration of the ICA have, in several coffee-producing countries, participated in the creation of a political and economic climate favorable to the current serious situations.

Although US foreign policy is not the focus of this dissertation, it is clear that it plays a part in the story being told here. The International Coffee Agreement was first created as a foreign policy tool for the consuming mostly Western nations to assist the developing world. No one pretended at that point that it would economically benefit the consuming countries. In 1989, when the agreement collapsed, the ideological environment had changed and this led the consuming countries, the United States in 
particular, to make other decisions and priorities. The reasons for the creation of the agreement however had not disappeared and new methods were put in place to deal with the problems at hand in those countries. Bilateral and multilateral assistance to coffeeproducing countries in general has doubled since the breakdown of the ICA. Assistance to Côte d'Ivoire, for example, increased from $\$ 403$ million in 1989 to $\$ 1153$ in 1995 while aid to Uganda went up from $\$ 371$ million in 1989 to $\$ 812$ million in 1995 . $^{2}$

The collapse of the International Coffee Agreement was thus an important turning point for coffee-producing countries and the parastatals they created to manage their coffee sectors. The story does not end here, however. Many Southern countries are still producing and exporting coffee. They are still dependent on the fluctuating international prices and need assistance for economic development. The role of coffee parastatals has diminished across the board but some of the basic needs of small coffee growers are not being met and they are voicing their discontent with their situations. How does the developing state respond to the pressures from below while at the same time accepting the economic constraints imposed from above?

${ }^{2}$ United Nations, Statistical Yearbook 1990/1991 (New York, NY: United Nations, 1993), p. 1057-1059 and United Nations, Statistical Yearbook 1995 (NewYork,NY: United Nations, 1997), p. 875-877. 


\section{BIBLIOGRAPHY}

\section{Primary Sources}

Newspaper and magazine articles on Colombia

"Aceptan prolongar el Pacto Cafetero," El Tiempo, October 3, 1989, p. 1A.

"Acuerdo cafetero para afrontar la crisis del fondo," El Tiempo, November 8, 1991, p. $1 \mathrm{~A}$.

"¿Adios al Pacto Cafetero?," El Tiempo, February 2, 1992, p. 6C.

"Administrando la riqueza," Semana, July 26, 1994, p. 60-62.

"Atrévase a ser empresario," El Caficultor, June 1991, p. 8.

"Bonos para financiar faltante de cafeteros," El Tiempo, October 23, 1991, p. 8A.

"Café: conciencia de crisis," El Tiempo, March 3, 1992, p. 4A.

"Café: se enfría el consumo," El Tiempo, November 25, 1991, p. $1 \mathrm{~B}$.

"Colombia no fué el mas agresivo," El Tiempo, January 22, 1990, p. 2B.

"Colombia se alista para exportar café procesado," El Tiempo, October 16, 1992, p. $5 \mathrm{D}$.

"Cuatro consejos para ser mas productivos," El Caficultor, December 1991, p. 14.

"Culpan a la Federación y al gobierno por crisis cafetera," El Tiempo, February 13, 1992, p. 12B.

"Cumbre de OIC: sin pena ni gloria," El Tiempo, October 6, 1989, p. 1A.

"Desconcierto en zonas productoras," El Tiempo, February 13, 1992, p. 3A.

DeYoung, Karen. "A Long Way From Coca to Coffee: U.S. Aid Tries To Get Colombian Peasant Farmers to Switch Cash Crops," The Washington Post, October 11, 2000., p. A18.

"El nuevo Viejo Caldas: una idea café con leche," El Tiempo, October 26, 1992, p. $8 \mathrm{~B}$. 
"El Paro," El Tiempo, July 19, 1995, p. 4A.

"El Ultimo Sorbo", Semana, August 25, 1992, pp. 54-55.

"Es difícil renegociación del nuevo Pacto Cafetero," El Tiempo, September 14, 1989, p. $11 \mathrm{C}$.

"Federación de Cafeteros debe reducir gastos," El Tiempo, June 8, 1990, p. 1B.

Galvis, Carlos Alberto. "Quindío: un polvorín en potencia," El Tiempo, March 23, 1993, p. 5E.

"Gobierno pide no hacer paro," El Caficultor, July 1995, p. 2.

"Ingresos por café superaron cálculos," El Tiempo, January 15, 1990, p. 1A

"La posición de Brasil deprime precio del café," El Tiempo, October 4, 1989, p. 1A.

"La virgen del Café," Semana, July 5, 1994, p. 52.

"Llegó la mala hora: cafeteros," El Tiempo, October 8, 1991, p. 6A.

"No al paro cafetero," El Caficultor, July 1995, p. 5.

"Nuestro objetivo: el hombre cafetero y su familia," El Caficultor, March 1991, p. 4.

"Numerosas organizaciones apoyan el Paro," El Tiempo, July 18, 1995, p. 13A.

"Ofensiva diplomática para restaurar pacto de café," El Tiempo, October 14, 1989, p. $6 \mathrm{~A}$.

"Pan de café: promoción en masa," El Tiempo, February 28, 1992, p. 2 A.

Parra, Martin Alonso. "Risaralda: del café a la seda," El Tiempo, February 10, 1990, p. $6 \mathrm{~B}$.

"Paro cafetero con aroma de guerrilla," El Tiempo, July 19, 1995, p. 5B.

"Paro divide a los cafeteros," El Tiempo, July 19, 1995, p. 1A.

"¿Quién cuidará del Eje Cafetero?" El Tiempo, October 24, 1992, p. 7B.

"Rechazan desmonte del Fondo," El Tiempo, March 5, 1993, p. 13A. 
"Sacrificio cafetero," El Caficultor, June 1992, p.1 and p. 4.

"Seis mil hectareas con broca," El Tiempo, June 8, 1990, p. 1B.

Suárez Montoya, Aurelio. "Aristas de la crisis cafetera," La Tarde (Pereira), April 1, 1992, p. 4.

Tovar Martinez, Edmer. "Cafeteros le sacan plata al paisaje," El Tiempo, October 21, 1996, p. 1B.

Tovar Martinez, Edmer. "Le tenemos más a la revaluación que a la broca," $E l$ Tiempo, October 20, 1996, p. 4C.

"Un nuevo pacto o retención, discutirán paises cafeteros," El Tiempo, November 15, 1991, p. 4C.

Newspaper and Magazine Articles on Côte d'Ivoire

Abiali. D.M. "Café-Cacao: Des GVC peu dynamiques," Fraternité Matin, June 21, 1983, p. 11.

Africa News Service, "Côte d'Ivoire at Loggerheads With IMF," March 2, 1999.

Africa News Service, "Côte d'Ivoire's Commodity Board Privatised," May 4, 1999.

"Agro-industries: des filières face au défi de la compétitivité, Marchés Tropicaux et Méditerranéens, July 2, 1993, p. 1696.

"Alain Gauze: 'Nous sommes trop dépendants du café et du cacao," Jeune Afrique, February 2-8, 1995, pp. 46-47.

"Café: 150,000 tonnes supplémentaires dans 13 ans," Fraternité Matin, October 28, 1986 , p. 23.

"Caistab: Un Garant de la Paix Sociale," Jeune Afrique, October 15-28, 1997, pp. 167170.

"Clashes and unrest grow fiercer in Ivory Coast," The New York Times, March 3, 1990, p. 3.

"Des armes pédagogiques aux encadreurs," Fraternité Matin, April 20, 1994, p. 5. 
Dorce, Frédéric; Géraldine Faes and Augustin Thiam. "Cinq scénarios pour Houphouet," Jeune Afrique, July 23-29, 1992, pp. 16-19.

"Dur, dur pour les paysans," Ivoir Soir, May 15, 1995.

"Interview: Alassane Ouattara," Jeune Afrique, May 15-21, 1991, p. 110.

Koné, Saliou. "La Production du Café et du Cacao En Baisse," Fraternité Matin, May 25, 1984, p. 10.

"La Caistab sera privatisée, selon M. Kouassi, Marchés Tropicaux et Méditerranéens, September 19, 1997, p. 2055.

"La campagne a mal à l'Etat," Jeune Afrique, November 9-15, 1995, pp. 124-129.

"Le chef d'état à propos des mesures envisagées: 'Portez le message à vos frères',"

Fraternité Matin, March 12, 1990, p. 7.

"Le plan relance du café sera maintenu," Fraternité Matin, August 29, 1988, p. 21.

"Le President à propos des sacrifices consentis," Fraternité Matin, March 7, 1990, p. 11-15.

"Les campagnes 76-77 ont démarré," Fraternité Matin, October 6, 1976, p. 3.

"Les cours boivent la tasse," Fraternité Matin, January 30, 1993, p. 3.

"Les nouveaux prix: un grand sacrifice," Fraternité Matin, October 28, 1986, p. 24.

"L'union fait la force," Jeune Afrique, March 23-29, 1995, pp. 48-49.

Massou, Assou. "La Côte d'Ivoire: Eveil d'un elephant,"Jeune Afrique, November 1995, pp. 79-134.

Massou, Assou. "Oui à la libéralisation, mais à notre rhythme!," Jeune Afrique, August 6-12, 1997, pp. 82-84.

Mori, Doumbia. "Mettre fin a la vente hors circonscription, Fraternité Matin, October $8,1986$.

"Priorité aux GVC," Fraternité Matin, October 28, 1986, p. 25.

Solo, Hien. "La difficile évolution," Fraternité Matin, September 30, 1993, p. 2. 
Solo, Hien. "La recherche de la competitivité," Fraternité Matin, May 27, 1990, p. 6.

Solo, Hien. "La relance, désormais certaine," Fraternité Matin, September 9, 1994, p. 2.

Solo, Hien. "La saga de l'arabusta," Fraternité Matin, June 8, 1989, p. 6.

Solo, Hien. "La stabilisation des prix maintenus," Fraternité Matin, September 17, 1995, p. 6.

Solo, Hien. "On cultive un nouvel esprit de rigueur et de transparence," Fraternité Matin, October 23, 1991.

Solo, Hien. "Pour sortir de la crise: le plan de bataille de Moise Koumoue Koffi," Fraternité Matin, February 8, 1990, p. 21.

Solo, Hien. "Producteurs, les crédits de campagne sont là," Fraternité Matin, August 10,1994, p. 5.

Solo, Hien. "Rétablir la production ivoirienne," Fraternité Matin, March 20, 1994, p. 14.

Newspaper and Magazine Articles on Coffee

Brooke, James. "A New Coffee Cartel Tries Its Hand," The New York Times, October 3, 1993, p. F11.

"Cartel Begun on Coffee," The New York Times, August 18, 1993, p. D2.

Interviews cited

Mr. Antoine, Agricultural Attache, United States Embassy, Abidjan Côte d'Ivoire, July 1997.

Mr. Denis Brakanon, former Minister of Agriculture, July 1997.

Director of Centro Nacional de Investigaciones del Café, Chinchiná, Colombia, March 1997.

Dr. Edgar Echeverri, Comité Nacional de Cafeteros de Colombia, Bogotá, Colombia, June 1997. 
Dr. Hernán Correo, Director of the Fundación Manuel Mejía, Chinchiná, Colombia, April 1997.

Mr. Gabriel García, Agricultural Engineer, Salamina, Colombia, April 1997.

Mrs. Mathilde Kouassi, Manager for Coffee, The Caisse de Stabilisation, Abidjan, Côte d'Ivoire, July 1997.

Ms. Olga, Extension Agent, Comité de Cafeteros, Chinchiná, Colombia, April 1997.

Mr. Marcelin Otteme, Specialist Technician, ANADER, Daloa, Côte d'Ivoire, July 1997.

Mr. Adriano Antonio Rodríguez Torres, Extension Agent, Salamina, Colombia, April 1997.

Mr. Luis Alberto Soto, Cooperative Director, Salamina, Colombia, April 1997.

Mr. Tapé, Chamber of Agriculture, Daloa, Côte d'Ivoire, July 1997.

Mr. Yapou, Bureau d'Etudes Techniques et de Développement, Abidjan, Côte d'Ivoire, July 1997.

Mr. Luis Alfonso Zuluaga, Comité de Cafeteros, Chinchiná, Colombia, April 1997.

\section{Official Documents}

Clavijo, Sergio; Jaramillo, Carlos Felipe and Leibovich, José, eds. El Negocio Cafetero Ante El Mercado Libre: Informe de la Comisión Mixta del Café. Bogotá, Colombia: TM Editores, 1994.

Colombian Information Service, "Special Issue: The International Coffee Agreement: A Twenty-Six Year Sucess Story," Colombia Today. New York, NY, 1989.

"El Servicio de Extensión Agricola en la Federación de Cafeteros, Revista Cafetera, pp. 59-66, 1960.

Fundación Manuel Mejía, Brochure, 1995.

Gobernación del Quindío, "El Quindío Es Café y Mucho Más," 1995.

International Coffee Agreement Between The United States of America and Other Governments, 1962. 
International Coffee Agreement Between The United States of America and Other Governments, 1968.

International Coffee Agreement Between The United States of America and Other Governments, 1983.

International Monetary Fund, Press Release No. 95/30, "IMF Approves Second Annual Loan Under the ESAF," May 22, 1995.

International Monetary Fund, Press Release No. 98/16885, "World Bank and IMF Approve Debt Reduction Package for Côte d'Ivoire," March 19, 1998.

Laporte, Bertrand. Les Reformes Des Systèmes de Commercialisation et de Stabilisation des Filières Café et Cacao au Cameroun et en Côte d'Ivoire. Paris, France: Ministère de la Coopération et du Développement, 1992.

McGhee, Honorable George. Statement, Hearing Before The Committee on Foreign Relations, United States Senate, Eighty-Eighth Congress, March 12, 1963.

Ministère de l'Information. Le Café et Le Cacao Dans l'Economie Ivoirienne. Abidjan, Côte d'Ivoire, 1972.

Ministère du Plan. Côte d'Ivoire 2000. Abidjan, Côte d'Ivoire: Editions Neter, 1994.

World Bank. Côte d'Ivoire: Revue de l'Aide de la Banque Mondiale Au Pays. Washington, DC: World Bank, 1999.

\section{$\underline{\text { Secondary Sources }}$}

Adams, F. Gerard and Jere R. Behrman. Commodity Exports and Economic Development. Lexington, MA: Lexington Books, 1992.

Aharoni, Yair. The Evolution and Management of State Owned Enterprises. Cambridge, MA: Ballinger Publishing Company, 1986.

Akiyama, Takamasa and Panatoyis N. Varangis. "The Impact of The International Coffee Agreement on Producing Countries," The World Bank Economic Review, 4,2, pp. 157-173, 1990.

Akiyama, Takamasa and Panos Varangis. "Perspectivas del Mercardo Mundial del Café," in Pontificia Universidad Javerania Departamento de Planeación, Economía Cafetera: Crisis y Perspectivas. Bogotá, Colombia: Centro Editorial Javeriano, 1993. 
Araim, Amer Salih. Intergovernmental Commodity Organizations and The New International Economic Order. New York, NY: Greenwood Publishing Group, 1991.

Arango Londoño, Gilberto. Por Los Senderos del Café: De La Gran Bonanza a la Peor Crisis: 1975-1993. Bogotá, Colombia: Ediciones Fondo Cultural Cafetero, 1994.

Aribisala, Femi. "The Political Economy of Structural Adjustment in Côte d'Ivoire," in Adeyabo Olukoshi, R. Omotayo Olaniyan and Femi Aribisala (eds.), Structural Adjustment in West Africa. Lagos, Nigeria: Pumark Nigeria Limited, 1994.

Attebi, Dadié. Le Défi Africain: L'urgence d'une alternative économique en Côte d'Ivoire. Paris, France: L'Harmattan, 1995.

Azam, Jean-Paul and Christian Morrisson. The Political Feasibility of Adjustment in Côte d'Ivoire and Morocco. OECD, 1994.

Bagley, Bruce. "National Front and Economic Development," in Robert Wesson (ed.), Politics, Policies \& Economic Development in Latin America. Stanford, CA: Hoover Institution Press, 1984.

Barker, Jonathan. Rural Communities Under Stress: Peasant Farmers and The State in Africa. New York, NY: Cambridge University Press, 1989.

Bassett, Thomas. Food, Peasantry and The State in The Northern Ivory Coast:18981982. Berkeley, CA: University of California, Ph.D. dissertation, 1984.

Bates, Robert. Markets and States in Tropical Africa: The Political Basis of Agricultural Policies. Berkeley, CA: University of California Press, 1981.

Bates, Robert. Open-Economy Politics: The Political Economy of World Coffee Trade. Princeton, NJ: Princeton University Press, 1997.

Bates, Robert and Da-Hsiang Donald Lien, "On The Operations of The International Coffee Agreement," in International Organization 39, 3 (Summer 1985), pp. 553-559.

Berquist, Charles W. Coffee and Conflict in Colombia, 1886-1910. Durham, NC: Duke University Press, 1986. 
Bigsten, Anne and Steve Kayizzi-Mugerwa. Crisis, Adjustment and Growth in Uganda: A Study of Adaptation in an African Economy. New York, NY: St. Martin's Press, 1999.

Boone, Catherine. "The Social Origins of Ivoirian Exceptionalism: Rural Society and State Formation," Comparative Politics, July 1995, pp. 445-463.

Boone, Catherine. "State Building in The African Countryside: Structure and Politics at The Grassroots," The Journal of Development Studies, 34, 4, pp. 1-31, 1998.

Bradford, Colin. Redefining The State in Latin America. Paris, France: OECD, 1994.

Brandt, Harmut. The Formulation of a New Coffee Agreement. Berlin, Germany: The German Development Institute, 1991.

Bratton, Michael. "Beyond The State: Civil Society and Associational Life in Africa," World Politics 41, 3, 1989.

Bratton, Michael. "Peasant-State Relations in Postcolonial Africa: Patterns of Engagement and Disengagement," in Migdal, Joel; Kohli, Atul; and Shue, Vivienne, eds. State Power and Social Forces: Domination and Transformation in the Third World. New York, NY: Cambridge University Press, 1994.

Campbell, Bonnie. "The Ivory Coast," in John Dunn (ed.), West African States: Failure and Promise. New York, NY: Cambridge University Press, 1978.

Campbell, Bonnie. "The State and Capitalist Development in the Ivory Coast" in Paul M. Lubeck (ed.) The African Bourgeoisie: Capitalist Development in Nigeria, Kenya, and the Ivory Coast. Boulder, CO: Lynne Rienner Publishers, 1987.

Campbell, Bonnie and John Loxley (eds.). Structural Adjustment in Africa. New York, NY: St. Martin's Press, 1989.

Chalarca, Jose. El Café En La Vida de Colombia. Bogotá, Colombia: Federación Nacional de Cafeteros de Colombia, 1987.

Colin, Jean-Philippe and Bruno Losch. "Touche pas à mon planteur: Réflexions sur les encadrements paysans à travers qulques exemples ivoiriens," Politique Africaine, 40, pp. 83-99, 1990.

Contamin, Bernard and Harris Memel-Fotê (eds.). Le Modèle Ivoirien En Questions: Crises, Ajustements, Recompositions. Paris, France: Editions Karthala, 1997. 
Crook, Richard. "Patrimonialism, Administrative Effectiveness and Economic Development in Côte d'Ivoire," African Affairs, 88, p. 205-228, 1989.

Crook, Richard. "Politics, The Cocoa Crisis, Administration in Côte d'Ivoire," The Journal of Modern African Studies, 28, 4, pp. 649-669, 1990.

Crook, Richard. "State, Society and Political Institutions in Côte d'Ivoire and Ghana," in James Manor (ed.), Rethinking Third World Politics. New York, NY: Longman, 1991.

Demery, Lionel. "Côte d'Ivoire:Fettered Adjustment," in Ishrat Husain and Rashid Faruqee (eds.), Adjustment in Africa: Lessons from Country Case Studies. Washington, DC: The World Bank, 1996.

Den Tuinder, Bastiaan. Ivory Coast: The Challenge of Sucess. Baltimore, MD: The Johns Hopkins University Press for the World Bank, 1978.

Dicum, Gregory and Nina Luttinger, The Coffee Book: Anatomy of An Industry From Crop To The Last Drop. New York, NY: The New Press, 1999.

Doornbos, Martin. "The African State in Academic Debate: Retrospect and Prospect," The Journal of Modern African Studies, 28, 2 (1990), pp. 179-198.

Economist Intelligence Unit, EIU Country Profile: Colombia, 1996-1997. London, United Kingdom.

Economist Intelligence Unit, EIU Country Profile: Colombia, 1997-1998. London, United Kingdom.

Economist Intelligence Unit, EIU Country Profile: Côte d'Ivoire Mali, 1993-1994. London, United Kingdom.

Economist Intelligence Unit, EIU Country Profile: Brazil, 1990-1991. London, United Kingdom.

Economist Intelligence Unit, EIU Country Profile: Brazil, 1991-1992. London, United Kingdom.

Economist Intelligence Unit, EIU Country Profile: Uganda, 1993-1994. London, United Kingdom.

Economist Intelligence Unit, EIU Country Report: Brazil, 1, 1990. London, United Kingdom. 
Economist Intelligence Unit, EIU Country Report: Brazil, 2, 1990. London, United Kingdom.

Economist Intelligence Unit, EIU Country Report: Indonesia, 3, 1990. London, United Kingdom.

Economist Intelligence Unit, EIU Country Report: Indonesia, 1, 1992. London, United Kingdom.

Economist Intelligence Unit, EIU Country Report: Nicaragua, Costa Rica and Panama, 3, 1989. London, United Kingdom.

Economist Intelligence Unit, EIU Country Report: Nicaragua, Costa Rica, Panama, 4, 1990. London, United Kingdom.

Economist Intelligence Unit, EIU Country Report: Nicaragua Costa Rica Panama, 4, 1992. London, United Kingdom.

Economist Intelligence Unit, EIU Country Report: Panama Costa Rica, 3, 1995. London, United Kingdom.

Economist Intelligence Unit, EIU Country Report: Uganda, 4, 1994. London, United Kingdom.

Economist Intelligence Unit, Quarterly Economic Review of Colombia and Ecuador, 4, 1983. London, United Kingdom.

Economist Intelligence Unit, Quarterly Economic Review of Colombia and Ecuador, 2, 1985. London, United Kingdom.

Economist Intelligence Unit, Quarterly Economic Review of Colombia and Ecuador, 3, 1985. London, United Kingdom.

Economist Intelligence Unit, Quarterly Economic Review of Colombia and Ecuador, 2, 1986. London, United Kingdom.

"El café: otra victima de la apertura," Deslinde, 12 (1992), pp. 23-34.

Errazuriz, Maria. Cafeteros y Cafetales Del Líbano: Cambio Technológico y Diferenciación Social en Una Zona Cafetera. Bogotá, Colombia: Universidad Nacional de Colombia, 1986. 
Errazuriz, Maria. "La Crisis de la Caficultura y Su Impacto Social," Analisis Politico, 20 (Sep/Dec 1993), pp. 64-70.

Escobar Tello, Maria. Fedecafé y Estado: Historia, Coyuntura, y Transformación de una Relación Paraestatal. Bogotá, Colombia: Universidad de los Andes Thesis, 1995.

Evans, Peter B.; Dietrich Rueschmeyer and Theda Skocpol. Bringing The State Back In. New York, NY: Cambridge University Press, 1985.

Faletto, Enzo. "The Specificity of The Latin American State, CEPAL Review, 38, pp. 69-87, 1989.

Farrington, John and Anthony Bebbington. Reluctant Partners? Non-Governmental Organizations, The State and Sustainable Agricultural Development. New York, NY: Routledge, 1993.

Fauré, Yves. "Côte d'Ivoire: Analyzing The Crisis," in Donal Cruis O'Brien, John Dunn and Richard Rathbone, Contemporary West African States. New York, NY: Cambridge University Press, 1989.

Fauré, Yves. "L'économie politique d'une démocratisation: Elements d'analyse à propos de l'experience récente de la Côte d'Ivoire, Politique Africaine, 43, pp. 31-49, 1991.

Fernandes, Praxy and Pavle Sicherl (eds.). Seeking The Personality of Public Enterprise: An Enquiry into the Concept, Definition and Classification. Ljubljana, Yugoslavia: International Center for Public Enterprises in Developing Countries, 1981.

Finlayson, Jock and Mark Zacher. Managing International Markets: Developing Countries and the Commodity Trade Regime. New York, NY: Columbia University Press, 1988.

Fisher, Bart. The International Coffee Agreement: A Study in Coffee Diplomacy. New York, NY: Praeger Publishers, 1972.

Geer, Thomas. An Oligopoly: The World Coffee Economy and Stabilization Schemes. New York, NY: Dunnellen Publishing Company, Inc., 1971.

Gerschenkron, Alexander. Economic Backwardness in Historical Perspective: A Book of Essays. Cambridge, MA: The Bellknap Press of Harvard University Press, 1962. 
Gilbert, Christopher L. "International Commodity Agreements: Design and Performance," World Development, 15, 5, pp. 591-616, 1987.

Gilpin, Robert. The Political Economy of International Relations. Princeton, NJ: Princeton University Press, 1987.

Gourevitch, Peter. Politics in Hard Times: Comparative Responses to International Economic Crises. Ithaca, NY: Cornell University Press, 1986.

Grindle, Merilee. State and Countryside: Development Policy and Agrarian Politics in Latin America. Baltimore, MD: The Johns Hopkins University Press, 1986.

Grootaert, Christian. "Structural Change and Poverty in Africa: A Decomposition Analysis for Côte d'Ivoire," The Journal of Development Economics, 47, pp. $375-401$.

Haas, Ernst. When Knowledge Is Power: Three Models of Change in International Organizations. Berkeley, CA: University of California Press, 1990.

Halliday, Fred. "State and Society in International Relations," in Michael Banks and Martin Shaw (eds.), State and Society in International Relations. New York, NY: St. Martin's Press, 1994.

Harbeson, John W; Donald Rothchild and Naomi Chazan. Civil Society and The State in Africa. Boulder, CO: Lynne Rienner Publishers, 1994.

Hartlyn, Jonathan. The Politics of Coalition Rule in Colombia. Cambridge, MA: Cambridge University Press, 1988.

Hecht, Robert. "The Ivory Coast Economic Miracle: What Benefit for Peasant Farmers?," The Journal of Modern African Studies, 21, 1, pp. 25-53, 1983.

Helmsing, A. H. J. Firms, Farms and The State in Colombia: A Study of Rural, Urban, and Regional Change. Boston, MA: Allen \& Unwin, Inc., 1986.

Hommes, Rudolf. "Discurso del Ministro de Hacienda, Rudolf Hommes, ante el XLIV Congreso Cafetero," Revista Cafetera, 199 (July-December 1989).

Hoos, Sidney. Agricultural Marketing Boards - An International Perspective. Cambridge, MA: Ballinger Publishing Company, 1979.

Huntington, Samuel. Political Order in Changing Societies. New York, NY: Yale University Press, 1968. 
Johnston, Bruce F. and Peter Kilby. Agriculture and Structural Transformation: Economic Strategies in Late-Developing Countries. New York, NY: Oxford University Press, 1975.

Jones, Leroy P. (ed.) Public Enterprise in Less-Developed Countries. New York, NY: Cambridge University Press, 1982.

Juárez, Carlos. "Trade and Development Policies in Colombia: Export Promotion and Outward Orientation, 1967-1992," Studies in Comparative International Development, 28, 3, pp. 67-97, 1993.

Koffman, Bennett. The National Federation of Coffee-Growers of Colombia. Charlottesville, VA: University of Virginia dissertation, 1969.

Kohli, Atul and Joel S. Migdal and Vivienne Shue (eds.). State Power and Social Forces: Domination and Transformation in The Third World (New York, NY: Cambridge University Press, 1994).

Koumoue, Moise Koffi. Politique Economique et Ajustement Structurel en Côte d'Ivoire. Paris: Editions L'Harmattan, 1994.

Krieger, Joel (ed.). The Oxford Companion to the Politics of the World. New York, NY: Oxford University Press, 1993.

Léonrad, Eric and Jonas-Guéhi Ibo, "Appropriation et gestion de la rente forestière en Côte d'Ivoire," Politique Africaine, 53, pp. 25-36, 1994.

Levy, Marc; Oran Young and Michael Zürn. "The Study of International Regimes," European Journal of International Relations, 1,3, pp. 267-330, 1995.

London, Christopher. The Cultural Politics of Technical Change in Colombian Coffee Production. Ithaca, NY: Cornell University Masters Thesis, 1994.

London, Christopher. "Class Relations and Capitalist Development: Subsumption in The Colombian Coffee Industry, 1928-1992." Paper presented at the 1995 Meeting of the Rural Sociological Society.

Losch, Bruno. "Les agro-exportateurs face à la dévaluation," Politique Africaine 54, pp. 88-103, 1994.

Lucier, Richard. The International Political Economy of Coffee: From Juan Valdez to Yank's Diner. New York, NY: Praeger Publishers, 1988. 
Maddox Toungara, Jeanne. "The Apotheosis of Côte d'Ivoire's Nana JHouphouetBoigny, The Journal of Modern African Studies, 28, 1 (1990), pp. 23-54.

Maldonado Delgado, Fernando. "Educacion y cultura cafetera en Risaralda: Cronica del desarraigo," Revistas de Ciencias Humanas, Universidad Tecnologica de Pereira, 4, 11(March 1997), pp. 52-58.

McGreevey, William. An Economic History of Colombia: 1845-1930. Cambridge, England: Cambridge University Press, 1971.

Médard, Jean-Francois. "The Historical Trajectories of The Ivoirian and Kenyan States," in James Manor (ed.), Rethinking Third World Politics. New York, NY: Longman, 1991.

Migdal, Joel. Strong Societies and Weak States: State-Society Relations and State Capabilities in the Third World. Princeton, NJ: Princeton University Press, 1988.

Mundt, Robert J. "Côte d'Ivoire: Continuity and Change in a Semi-Democracy," in John F. Clark and David E. Gardinier (eds.), Political Reform in Francophone Africa. Boulder, CO: Westview Press, 1997.

Munera Zuloaga, Rodrigo. "La Federación no es antidemocrática," Revista Cafetera de Colombia, 44, 204 (1995), pp. 59-69.

Mwandha, James; John Nichols and Malcolm Sargent. Coffee: The International Commodity Agreements. Brookfield, VT: Gower Publishing Company, 1985.

Naiman, Robert and Neil Watkins, "A Survey of The Impacts of IMF Structural Adjustment in Africa: Growth, Social Spending, and Debt Relief," Center for Economic Policy and Research paper, April, 1999.

Nanda, Serena. Cultural Anthropology Fourth Edition. Belmont, CA: Wadsworth Publishing Company, 1991.

Nieto Artera, Luis. El Café En La Sociedad Colombiana. Bogotá, Colombia: El Ancora Editores, 1992.

Nyong'o, Peter Anyang'. "The Development of Agrarian Capitalist Classes in The Ivory Coast, 1945-1975," in Paul M. Lubeck (ed.), The African Bourgeoisie: Capitalist Development in Nigeria, Kenya and The Ivory Coast. Boulder, CO: Lynne Rienner Publishers, 1987. 
Ortiz, Sutti. Harvesting Coffee, Bargaining Wages: Rural Labor Markets in Colombia, 1975-1990. Ann Arbor, MI: The University of Michigan Press, 1999.

Paige, Jeffery M. Coffee and Power: Revolution and The Rise of Democracy in Central America. Cambridge, MA: Harvard Unversity Press, 1997.

Palacios, Mauricio. Coffee in Colombia 1850-1970. New York, NY: Cambridge University Press, 1980.

Pearce, Jenny. Colombia: Inside The Labyrinth. London, England: Latin American Bureau, 1990.

Polanyi, Karl. The Great Transformation: The Political and Economic Origins of Our Time. Boston, MA: Beacon Press, 1957.

Priovolos, Theophilos. Coffee and The Ivory Coast: An Econometric Study. Lexington, MA: Lexington Books, 1981.

Ridler, Neil. "Comparative Advantage as a Development Model: The Ivory Coast," The Journal of Modern African Studies, 23, 3, pp. 407-417, 1985.

Ridler, Neil. "The Caisse de Stabilisation in the Coffee Sector in the Ivory Coast," World Development, 16, 12 (1988), pp. 1521-1526.

Rothchild, Donald and Naomi Chazan (eds.). The Precarious Balance: State and Society in Africa. Boulder, CO: Westview Press, 1988.

Rothstein, Robert L.. Global Bargaining: UNCTAD and The Quest For A New International Economic Order. Princeton, NJ: Princeton University Press, 1979.

Schneider, Harmut. Adjustment and Equity in Côte d'Ivoire. OECD, 1992.

Scott, James. Weapons of The Weak: Everyday Forms of Peasant Resistance. New Haven, CT: Yale University Press, 1985.

Sick, Deborah. "Coping With Crisis: Costa Rican Households and The International Coffee Market," Ethnology, 36, 3, pp. 255-75, 1997.

Sick, Deborah. Farmers of the Golden Bean: Costa Rican Households and the Global Coffee Economy. DeKalb, IL: Northern Illinois University Press, 1999. 
Spanier, John and Steven Hook. American Foreign Policy Since World War II. Washington, DC: Congressional Quarterly, Inc. 1998.

Streeten, Paul and Diane Elson. Diversification and Development: The Case of Coffee. New York, NY: Praeger Publishers, 1971.

Talbot, John. "Regulating The Coffee Commodity Chain: Internationalization and The Coffee Cartel," Berkeley Journal of Sociology, 40, pp. 113-148, 1995.

Timmer, C. Peter. Agriculture and The State: Growth, Employment and Poverty in Developing Countries. Ithaca, NY: Cornell University Press, 1991.

Thomas, Vinod. Linking Macroeconomic and Agricultural Policies for Adjustment with Growth: The Colombian Experience. Baltimore, MD: The Johns Hopkins University Press for the World Bank, 1985.

Uganda, January 1997. Analysis at the website of the International Coffee Organization. www.ico.org/pub/puprof2.html, May 19, 2000.

Widner, Jennifer A. "The 1990 Elections in Côte d'Ivoire, Issue, 20, 1, pp. 31-40, 1991.

Widner, Jennifer A. "The Origins of Agricultural Policy in Ivory Coast 1960-1986," Journal of Development Studies, 29, 4, pp. 26-59, 1993.

Widner, Jennifer A. "Single Party State and Agricultural Policies: The Cases of Ivory Coast and Kenya, Comparative Politics, June 1994, pp. 124-147.

Widner, Jennifer. "The Discovery of Politics: Smallholder Reactions to The Cocoa Crisis of 1988-90 in Côte d'Ivoire," in Thomas M. Callaghy and John Ravenhill (eds.), Hemmed In: Responses to Africa's Economic Decline. New York, NY: Columbia University Press, 1993, pp. 279-331.

Widner, Jennifer A. "Two Leadership Styles and Patterns of Political Liberalization," African Studies Review, 37, 1, pp. 151-174, 1994.

Widner, Jennifer A. Economic Change and Political Liberalization in Sub-Saharan Africa. Baltimore, MD: The Johns Hopkins University Press, 1994.

Williamson, John. "Democracy and the Washington Consensus," World Development, 21, 8, pp. 1329-1336, 1993. 
Woods, Dwayne. "Côte d'Ivoire: The Crisis of Distributive Politics," in Leonardo Villalon and Phillip A.Huxtable (eds.), The African State At a Critical Juncture: Between Disintegration and Reconfiguration. Boulder, CO: Lynne Rienner Publishers, 1998.

Woods, Dwayne. "The Politics of Organising the Countryside: Rural Cooperatives in Côte d'Ivoire, The Journal of Modern African Studies, 37, 3, pp. 489-506, 1999. 


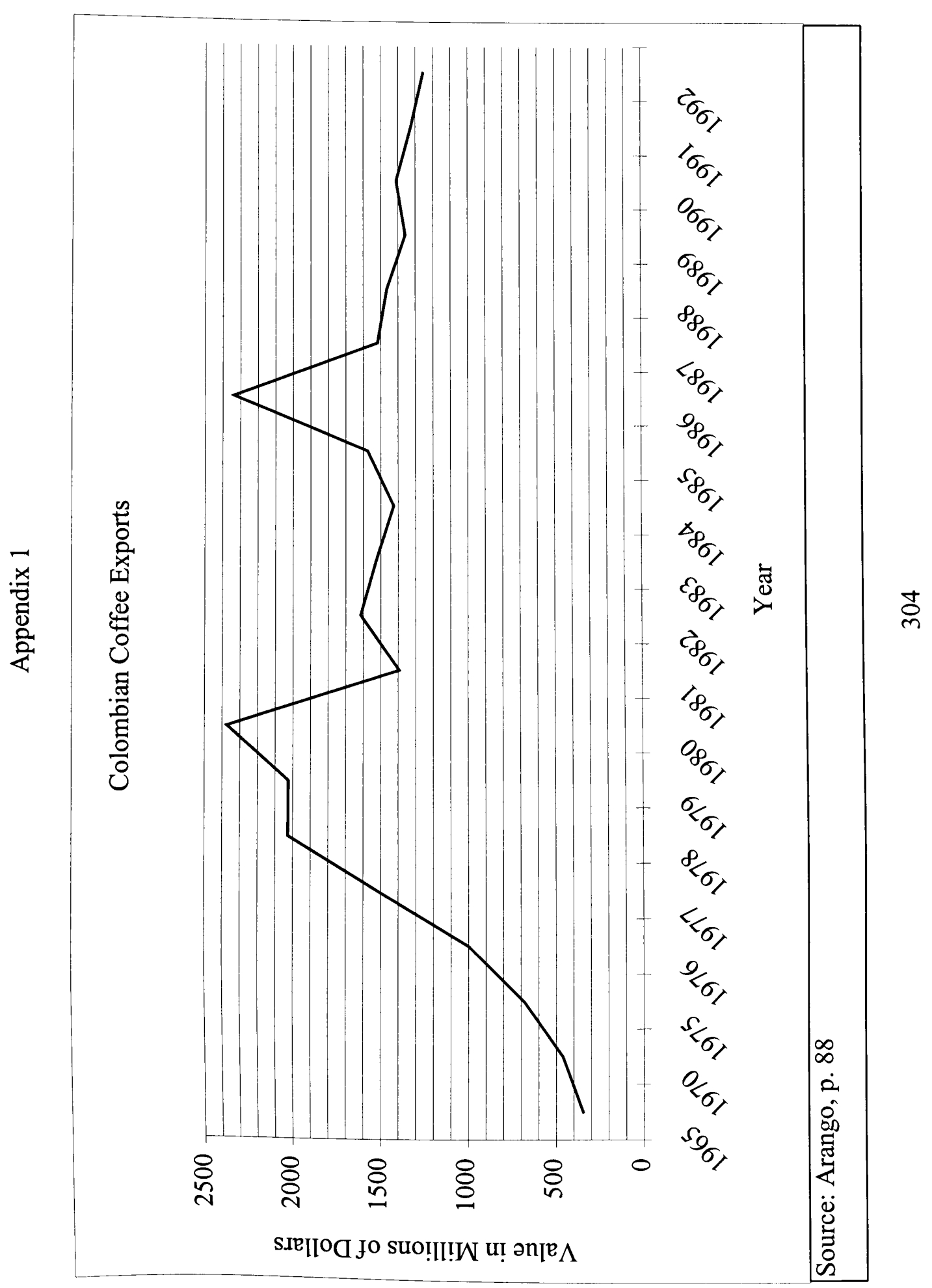




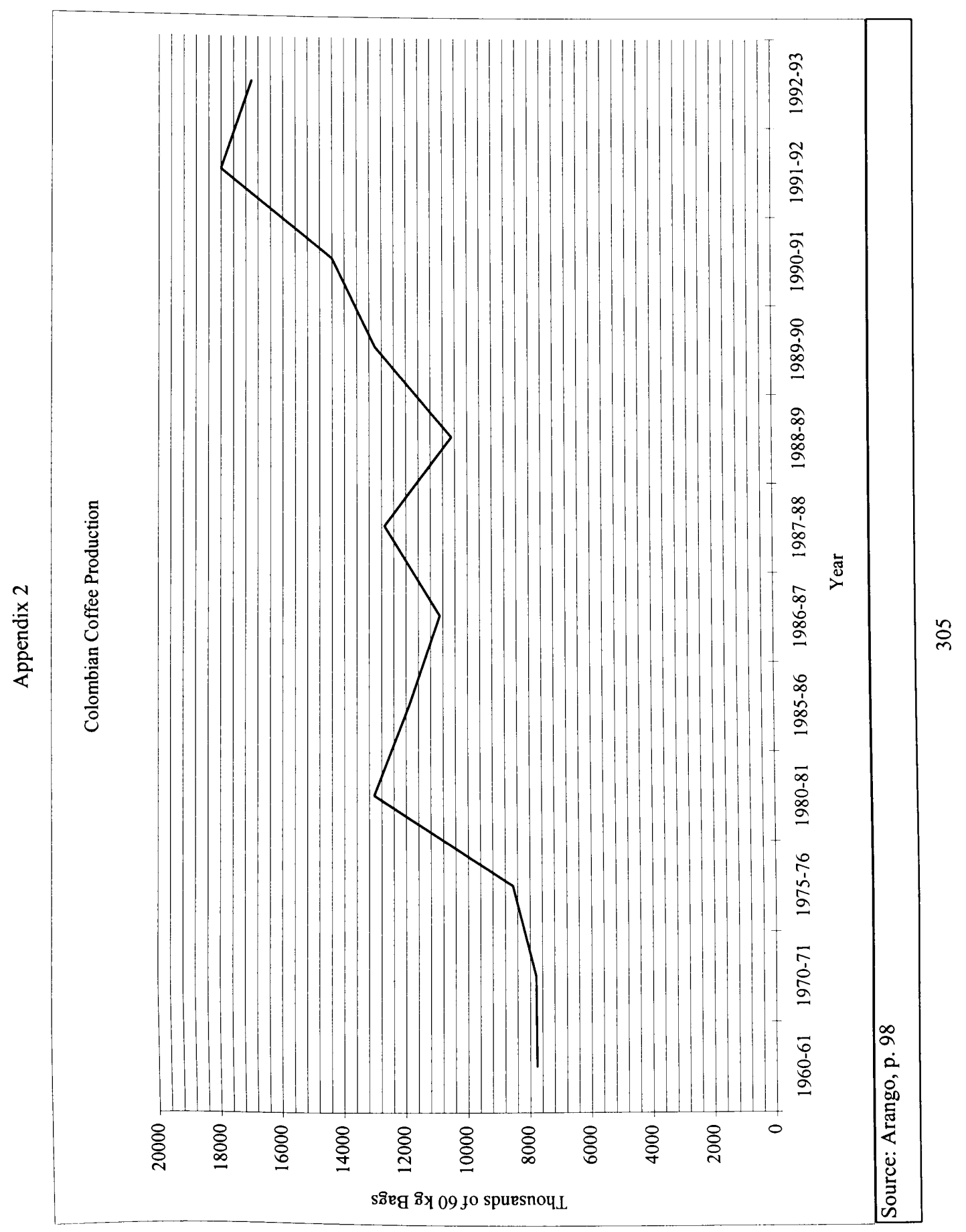




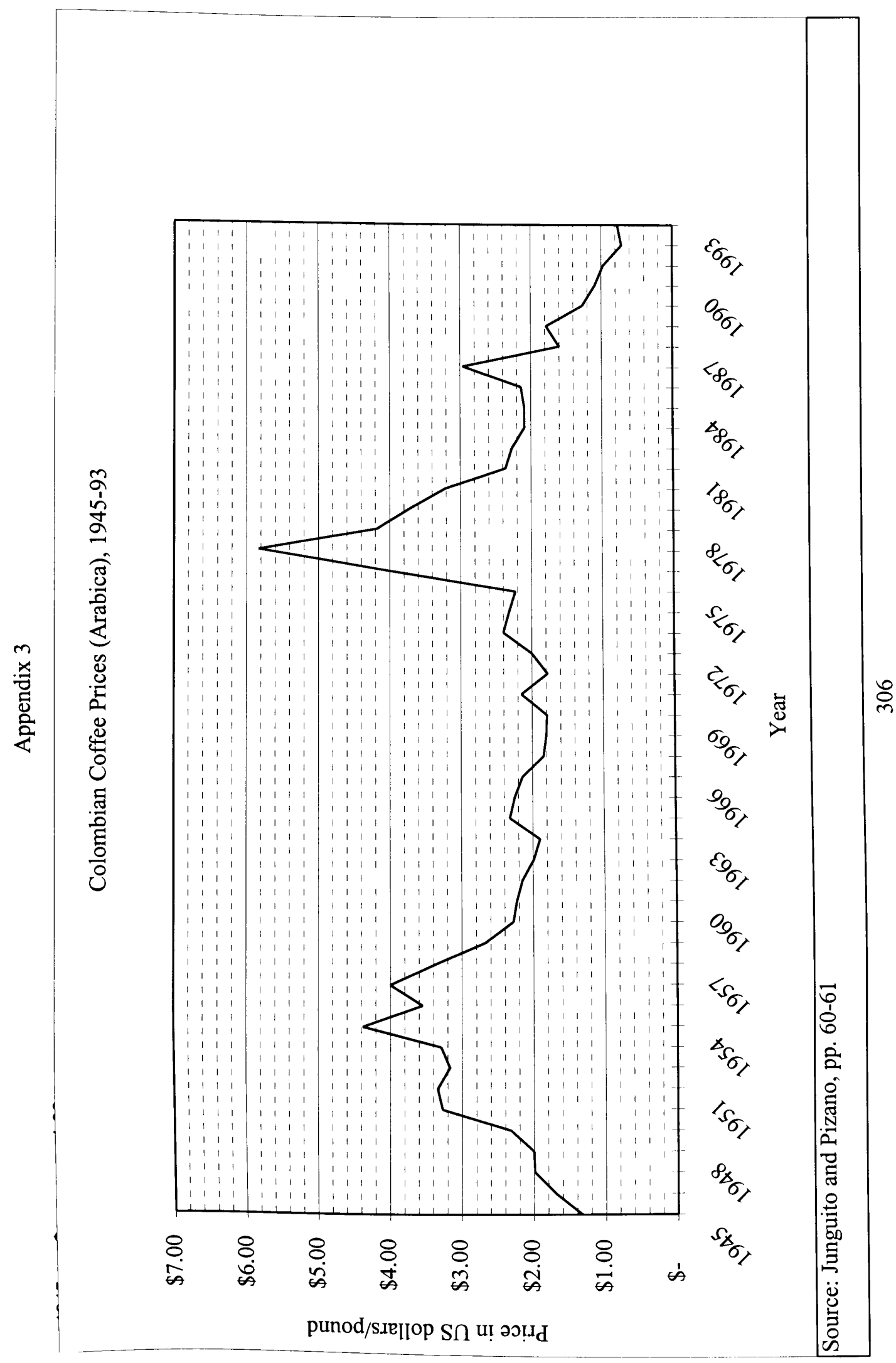




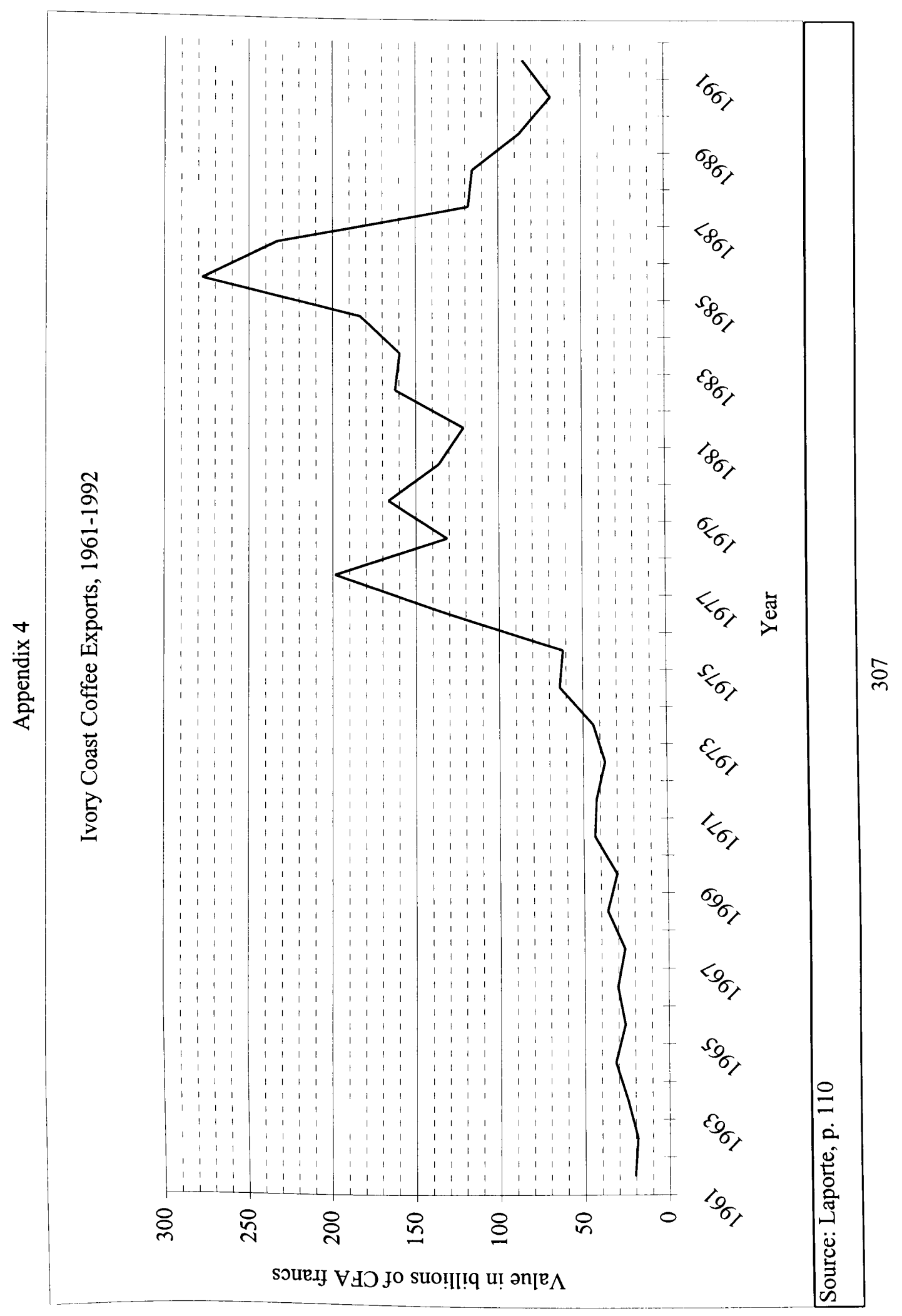




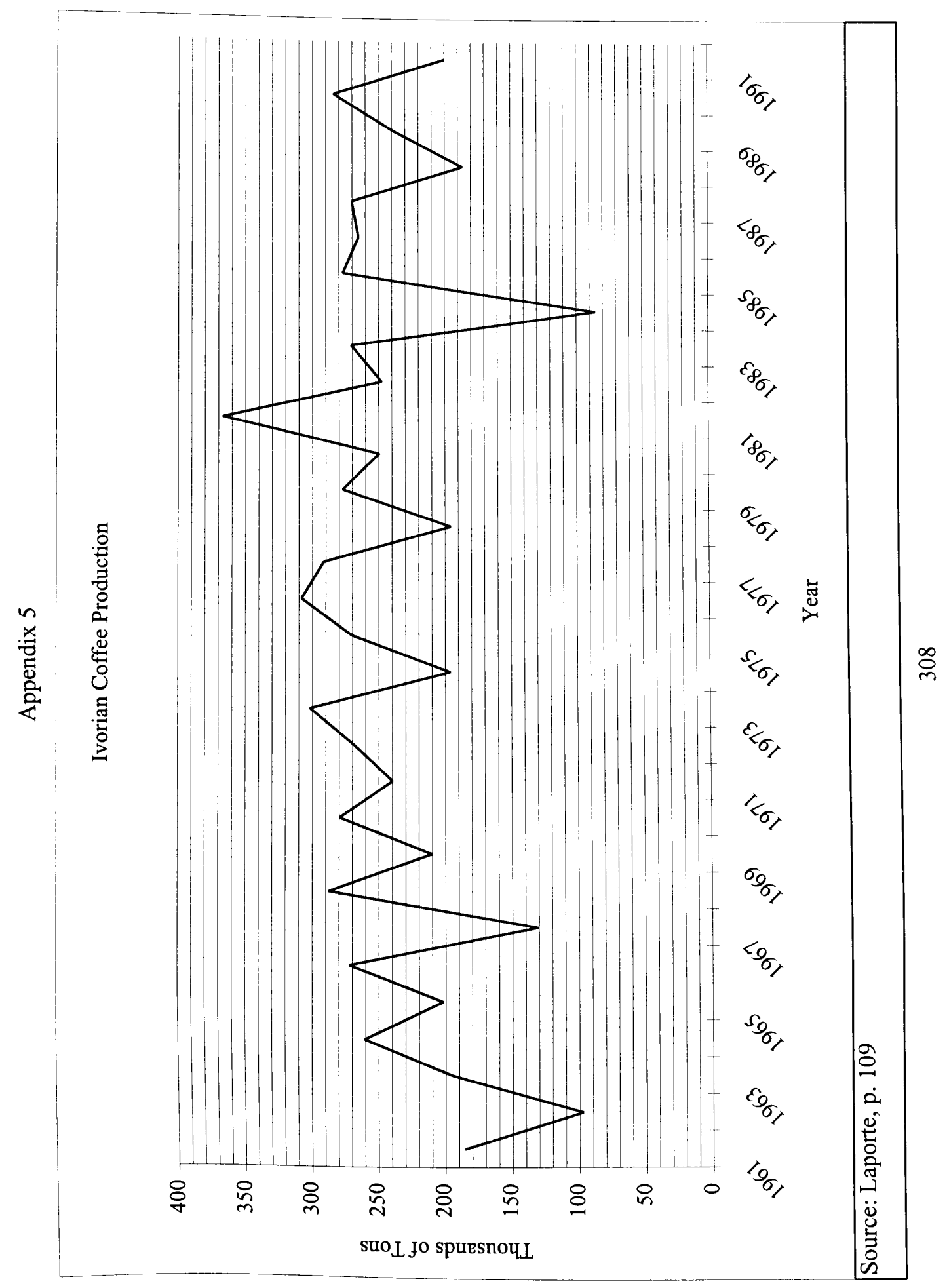




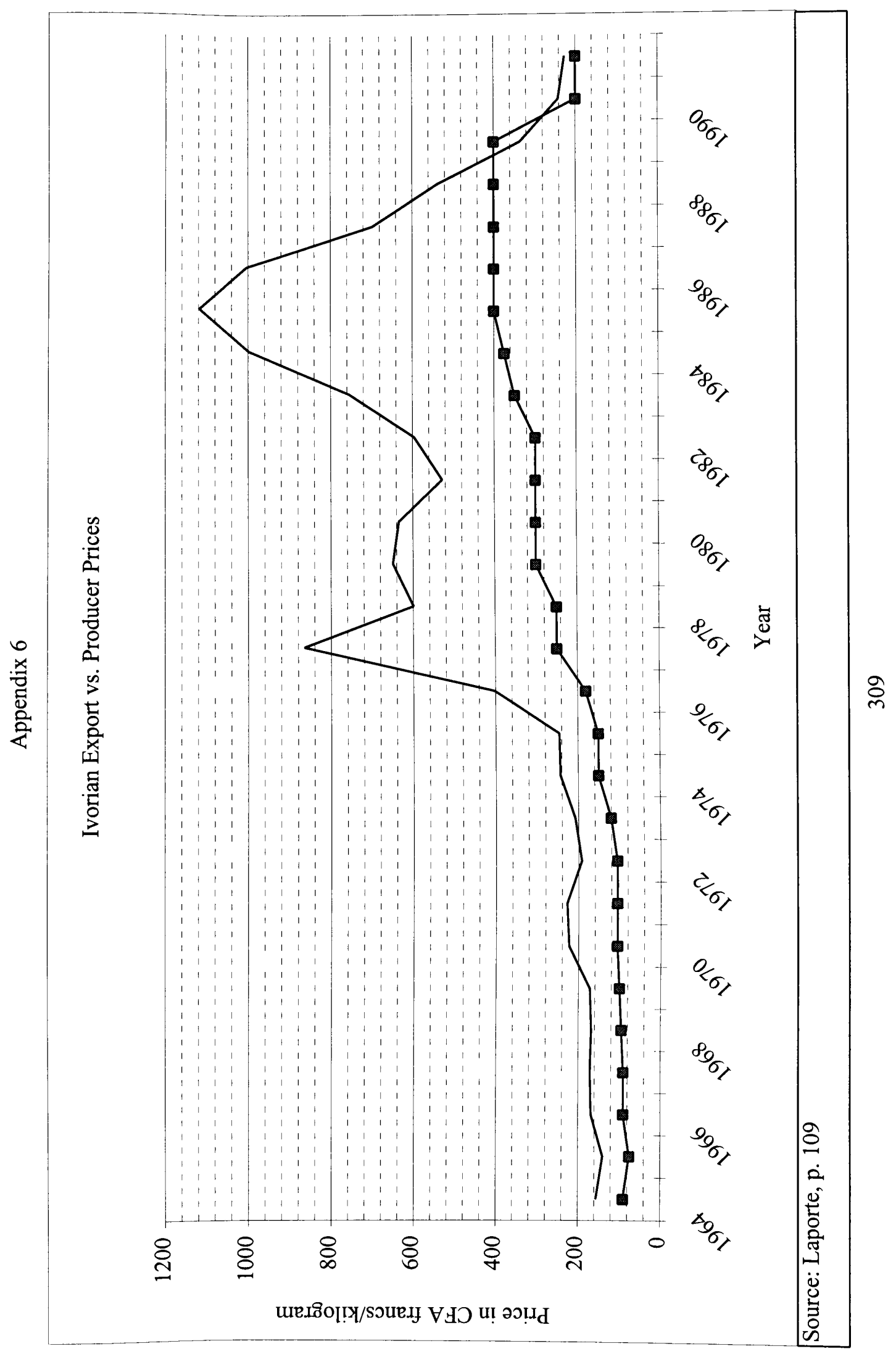




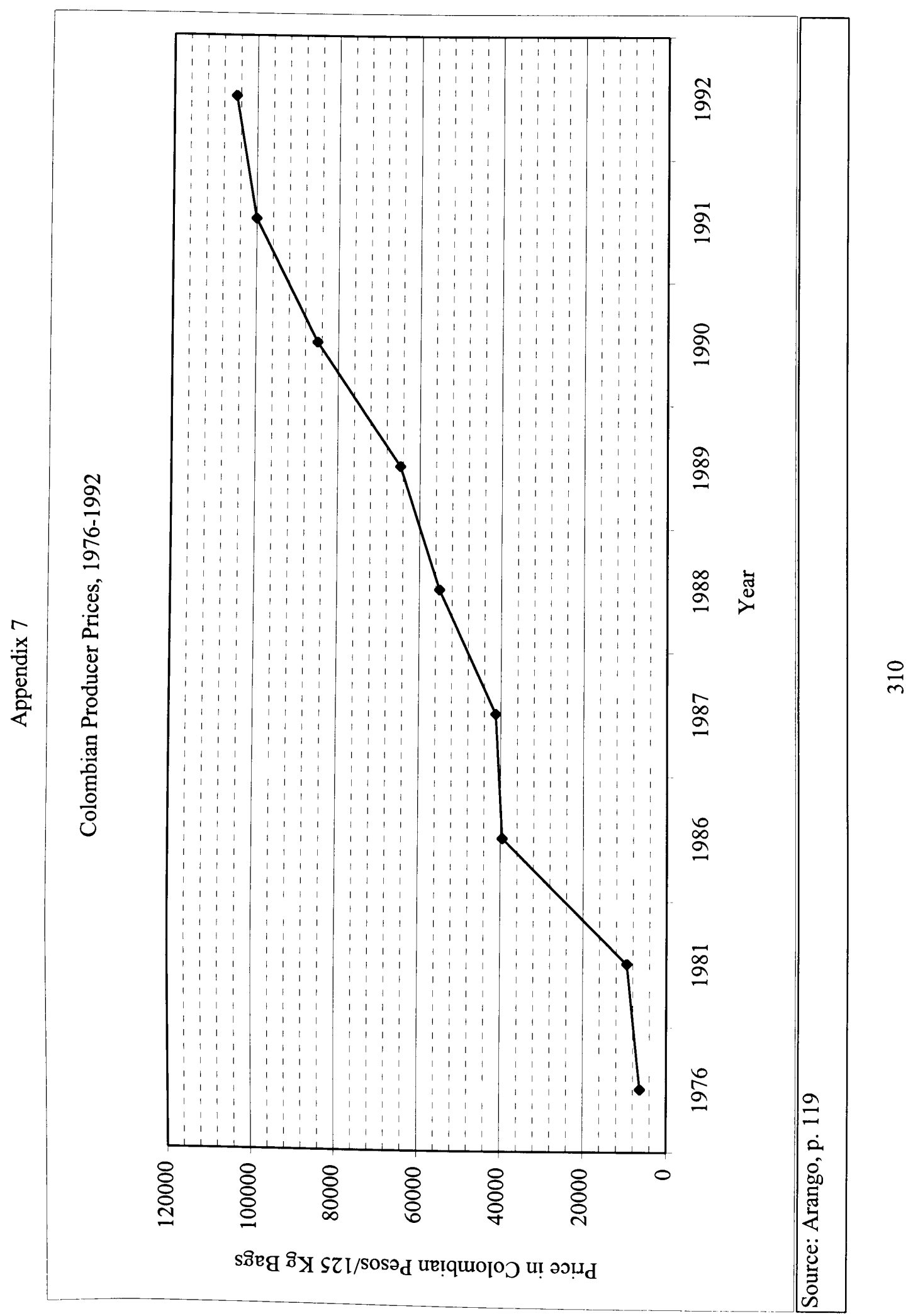




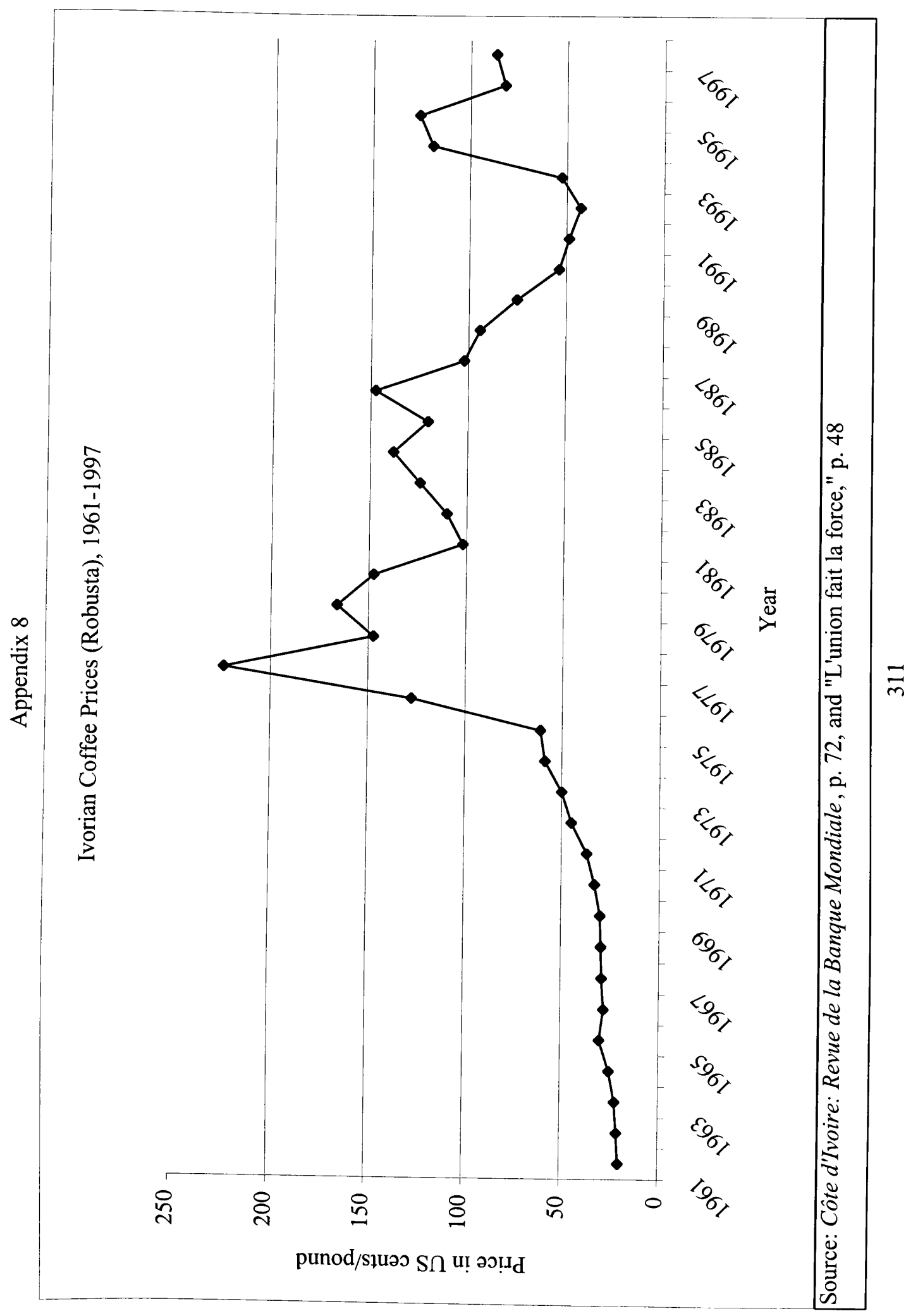




\section{VITA}

\section{LAURA ELIZABETH BOUDON}

1986

Baccalauréat

Lycée Auguste Renoir

Cagnes-Sur-Mer, France

1989

B.A., International Studies

University of North Carolina

Chapel Hill, North Carolina

1989-1990 Legal Assistant

Willkie Farr \& Gallagher

New York, New York

1990-1991 Legal Assistant

Willis Corroon Corporation

New York, New York

1993

M.A., International Affairs

University of Miami

Coral Gables, Florida

1994-1996 Graduate Assistant

Florida International University

University Park, Florida

1997-1999 Program Counselor

Georgetown University

Washington, District of Columbia

2000

Graduate Academic Advisor

American University

Washington, District of Columbia

\section{PUBLICATIONS AND PRESENTATIONS}

"The Federación Nacional de Cafeteros de Colombia since 1989: Its Changing Role and Position," LASA, Miami, March 2000.

"Burkina Faso: The Rectification of the Revolution," in John F. Clark and David Gardinier (eds.) Political Reform in Francophone Africa (Boulder: Westview Press, 1997). 
"Coffee and the Ivoirian Political Economy," ASA, San Francisco, November 1996.

"French and American Influences on Senegalese Democratization," ASA, Orlando, November 1995.

"Theoretical Approaches to Women's Organizations in Africa," ISA-South, Atlanta, October 1995.

Book Review of Dickson Mungazi, Educational Policy and National Character: Africa, Japan, the United States, and the Soviet Union (Wesport:Praeger Publishers, 1993), Journal of Third World Studies, Spring 1995.

Book Review of Nigel Worden, The Making of Modern South Africa: Conquest, Segregation, and Apartheid (Cambridge: Blackwell Publishers, 1994), Journal of Third World Studies, Spring 1995.

"Ethnicity and Nation-Building in Senegal," SSSA, Dallas, March 1995. 